\title{
Solar Thermal Financing Guidebook
}
T. A. Williams
I. Holmlund
R. J. Cole
S. Malhotra
D. R. Brown
S. A. Smith
J. A. Dirks
P. Sommers
H. Edelhertz
T. L. Willke

May 1983

Prepared by

Pacific Northwest Laboratory under a Related Services Agreement with the U.S. Department of Energy under Contract DE-AC06-76RLO 1830

Pacific Northwest Laboratory Operated for the U.S. Department of Energy by Battelle Memorial Institute 


\title{
DISCLAIMER
}

This report was prepared as an account of work sponsored by an agency of the United States Government. Neither the United States Government nor any agency thereof, nor any of their employees, makes any warranty, express or implied. or assumes any legal liability or responsibility for the accuracy, completeness, or usefulness of any information, apparatus, product, or process disclosed, or represents that its use would not infringe privately owned rights. Reference herein to any specific commercial product, process, or service by trade name, trademark, manufacturer, or otherwise, does not necessarily constitute or imply its endorsement, recomme:dation, or favoring by the United States Government or any agency thereof. The views and opinions of authors expressed herein do not necessarily state $\mathrm{cr}$ reflect those of the United States Government or any agency thereof.

\author{
PACIFIC NORTHWEST I.ABORATORY \\ operated by \\ BATTELLE \\ for the \\ UNITED STATES DEPARTMENT OF ENERGY \\ under Contract DE-AC06-76RLO 1830
}

\begin{tabular}{|c|c|}
\hline \multicolumn{2}{|c|}{ Printed in the United States of America } \\
\hline \multirow{2}{*}{\multicolumn{2}{|c|}{$\begin{array}{l}\text { Available from } \\
\text { National Technical Information Service }\end{array}$}} \\
\hline & \\
\hline \multirow{3}{*}{\multicolumn{2}{|c|}{$\begin{array}{c}\text { United States Department of Commerce } \\
5285 \text { Port Roval Road } \\
\text { Springfield, Virginia } 22151\end{array}$}} \\
\hline & \\
\hline & \\
\hline \multirow{2}{*}{\multicolumn{2}{|c|}{$\begin{array}{l}\text { NTIS Price Codes } \\
\text { Microfiche A01 }\end{array}$}} \\
\hline & \\
\hline \multicolumn{2}{|c|}{ Printed Copy } \\
\hline & Price \\
\hline Pages & Codes \\
\hline $001-025$ & $\mathrm{~A} 02$ \\
\hline $026-050$ & $\mathrm{~A} 03$ \\
\hline $051-075$ & $\mathrm{~A} 04$ \\
\hline $076-100$ & A05 \\
\hline $10:-125$ & A06 \\
\hline $126-150$ & $A 07$ \\
\hline $151-175$ & $A 08$ \\
\hline $176-200$ & A09 \\
\hline $201-225$ & $\mathrm{~A} 010$ \\
\hline $226-250$ & A011 \\
\hline $251-275$ & $\mathrm{~A} 012$ \\
\hline $276-300$ & A013 \\
\hline
\end{tabular}



T. A. Will jams
I. Holmlund (a)
R. J. Cole (a)
S. Malhotra (a)
D. R. Brown
S. A. Smith
J. A. Dirks
P. Sommers (a)
H. Edelhertz (a)
T. L. Will ke(b)

May 1983

Prepared by Pacific Northwest Laboratory under a Related Services Agreement with the U.S. Department of Energy under Contract DE-ACO6-76RLO 1830

Pacific Northwest Laboratory

Richland, Washington 99352

(a) Battelle Human Affairs Research Centers Seattle, Washington 98105

(b) Gas Research Institute Chicago, I1linois 60731 
This guidebook contains information on alternative financing methods that could be used to develop solar thermal systems. The financing arrangements discussed include several lease alternatives, joint venture financing, R\&D partnerships, industrial revenue bonds, and ordinary sales. In many situations, alternative financing arrangements can significantiy enhance the economic attractiveness of solar thermal investments by providing a means to efficiently allocate elements of risk, return on investment, required capital investment, and tax benefits.

A net present value approach is an appropriate method that can be used to investigate the economic attractiveness of alternative financing methods. Although other methods are applicable, the net present value approach has advantages of accounting for the time value of money, yielding a single valued solution to the financial analysis, focusing attention on the opportunity cost of capital, and being commonly understood concept that is relatively simple to apply. A personal computer model for quickly assessing the present value of investments in solar thermal plants with alternative financing methods is presented in this guidebook.

General types of financing arrangements that may be desirable for an individual can be chosen based on an assessment of his goals in investing in solar thermal systems and knowledge of the individual's tax situation. Once general financing arrangements have been selected, a screening analysis can quickly determine if the solar investment is worthy of detailed study. 


\section{CONTENTS}

SUMMARY

FIGURES

TABLES

1.0 INTRODUCTION

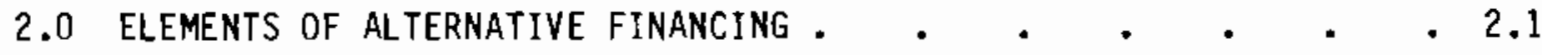

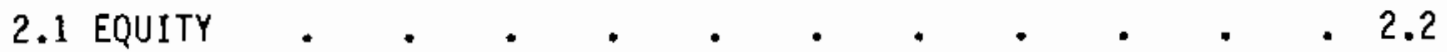

2.2 DEBT . . . . . . . . . . . . . . . 2.3

2.2 .1 Maturity . $. \quad . \quad . \quad . \quad . \quad . \quad . \quad .2 .3$

2.2 .2 Repayment Provision . . . . . . . . 2.3

2.2 .3 Seniority . . . . . . . . . 2.4

2.2 .4 Security. $. \quad . \quad . \quad . \quad . \quad . \quad . \quad . \quad 2.4$

2.2 .5 Interest Rates . . . . . . . . . 2.5

2.3 GRANTS $. \quad . \quad . \quad . \quad . \quad . \quad . \quad . \quad . \quad .5$

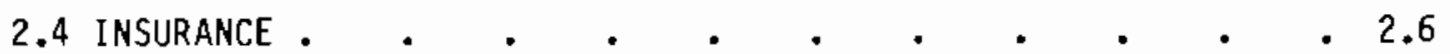

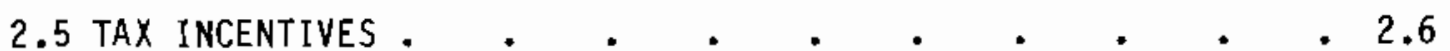

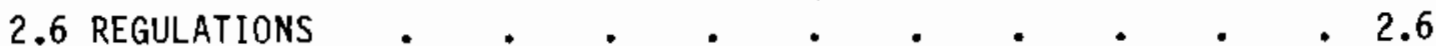

3.0 parties to alternative financing .

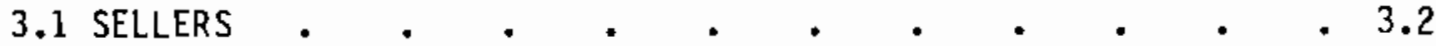

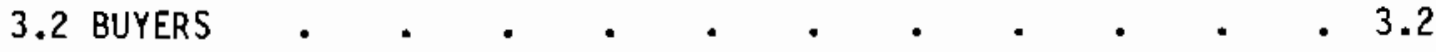

3.3 THIRD PARTIES .

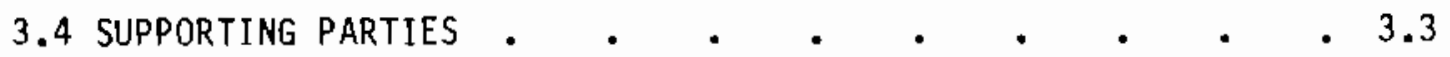

3.4 .1 Banks . . . . . . . . . . . . 3.4

3.4 .2 Finance Companies . . . . . . . . 3.6

3.4.3 Individual Investors and Investor Groups . • 3.6

3.4.4 Limited Partnerships . . . . . . . . 3.7

3.4.5 Research and Development Partnerships . . . . 3.8

3.4.6 Industrial Users of Electricity and Heat . . . 3.8

3.4.7 Solar Thermal Equipment Manufacturers . . . . 3.9

3.4.8 Energy Management Companies . . . . . . . 3.9

3.4 .9 Utilities . . . . . . . . . . . . 3.9

3.4.10 Insurance Companies . . . . . . . 3.10

3.4.11 Venture Capital Firms . . . . . . . . 3.10 
3.4.12 Leasing Companies . . . . . . . . . 3.10

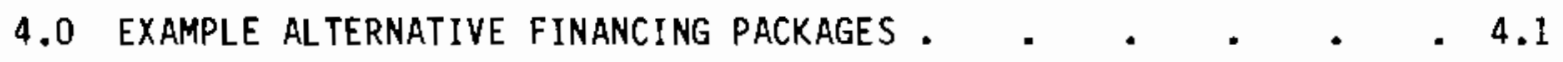

4.1 OROINARY SALE . . . . . . . . . . . . . . . 4.1

4.2 SALE HITH BORROWED FINANCING . . . . . . . . . 4.1

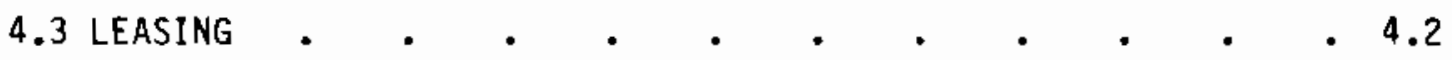

4.3 .1 Ordinary Lease . . . . . . . . . . 4.3

4.3.2 Third-Party Lease. . . . . . . . 4.3

4.3.3 Leveraged Leasing . . . . . . . . 4.4

4.3.4 Sale-Leaseback Method . . . . . . . . 4.5

4.4 JOINT VENTURE FINANCING . . . . . . . . . . . 4.8

4.5 RESEARCH AND DEVELOPMENT PARTNERSHIPS . . . . . . 4.8

4.6 INOUSTRIAL REVENUE BONDS • . . . . . . . . . . 4.8

5.0 EVALUATION OF ALternative FinANCING PACKAGES $\quad$ • 5.1

5.1 BASIC FINANCIAL CONCEPTS . . . . . . . . . . 5.1

5.1 .1 Time Value of Money . . . . . . . . 5.1

5.1 .2 Nominal and Real Interest Rates . . . . . 5.2

5.1 .3 Current and Constant Dollars . . . . . 5.3

5.1 .4 Tax Liability . . . . . . . . . . 5.4

5.1 .5 Tax Credits . . . . . . . . . . 5.7

5.2 possible evaluation Methodologies . . . . . . . 5.8

5.2 .1 Net Present Value. . . . . . . . 5.8

5.2 .2 Profitability Index . . . . . . . 5.11

5.2 .3 Internal Rate of Return . . . . . . 5.12

5.2 .4 Payback Period . . . . . . . . . . 5.14

6.0 COMPUTER MODELING EQUATIONS FOR EVALUATING

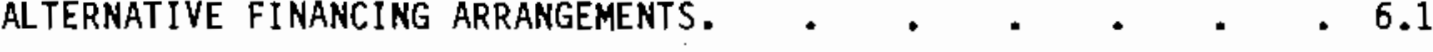

6.1 USER AND TECHNOLOGY SPECIFIC PARAMETERS • $\quad . \quad . \quad \cdot \quad \cdot 6.1$

6.2 MODEL FINANCIAL EQUATIONS AND METHODOLOGY . • • • . 6.3

6.2 .1 Total Costs . . . . . . . . . 6.3

6.2.2 Operating and Maintenance Costs . . . . . . 6.3

6.2 .3 Loan Payment . . . . . . . . . . . 6.4

6.2 .4 Loan Interest Payment . . . . . . . . 6.4

6.2 .5 State Taxes . . . . . . . . . . . 6.4

6.2.6 Federal Income Tax $. \quad . \quad . \quad . \quad . \quad . \quad .6 .4$ 
6.2.7 Total Tax Liability . . . . . . . . 6.5

6.2 .8 Energy Revenue . . . . . . . . 6.5

6.2 .9 Effective Net Cash Flow . . . . . 6.5

6.2.10 Effective Present Value . . . . . . . 6.6

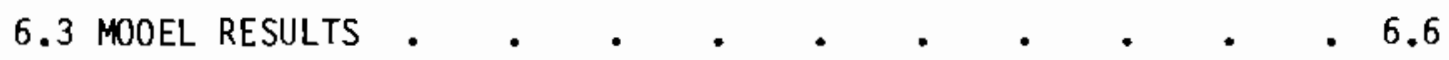

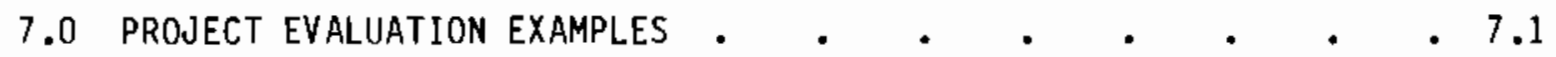

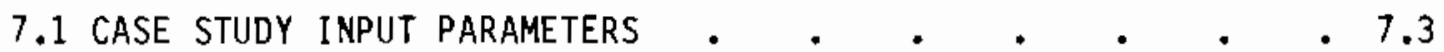

7.1 .1 Plant Parameters . . . . . . . . 7.3

7.1 .2 Economic Parameters . . . . . . . . 7.3

7.2 CASH FLOW ANALYSIS FOR PROJECT EXAMPLES • • • • • 7.8

7.2.1 Sale With Borrowed Financing . . . • . . 7.8

7.2 .2 Third-Party Leasing . . . . . . . 7.10

7.2 .3 Leveraged Lease $. \quad . \quad . \quad . \quad . \quad . \quad$. 7.13

7.2 .4 Sale-Leaseback $. \quad . \quad . \quad . \quad . \quad .7 .13$

7.2 .5 Industrial Revenue Bonds . . . . . . . 7.19

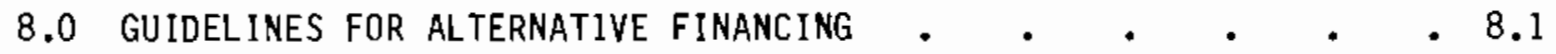

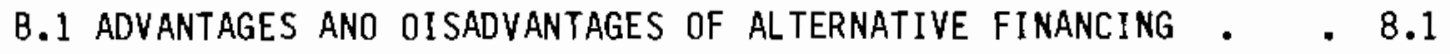

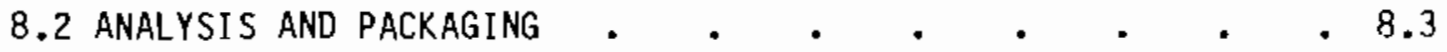

8.2.1 Tax Credits . . . . . . . . 8.5

8.2.2 Initial Energy Price . . . . . . . 8.6

8.2.3 Energy Escalation Rates . . . . . . . 8.6

8.2 .4 Discount Rate $\quad . \quad$. $\quad . \quad . \quad .8 .7$

8.2.5 Loan Life and Interest Rate . . . . . . 8.7

8.2.6 Initial Plant Cost $\quad . \quad . \quad . \quad . \quad . \quad . \quad .8 .7$

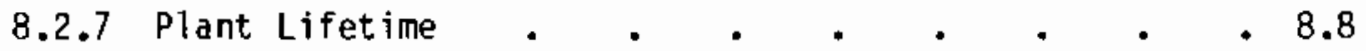

8.2.8 Initial 0perating and Maintenance Costs . . $\quad$ • 8.8

8.2.9 Thermal Versus Electric Energy Production . . . 8.8

8.2 .10 Summary . . . . . . . . . . . . 8.10

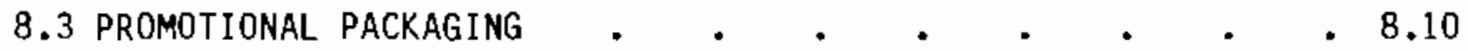

8.4 ALTERNATIVE FINANCING CDNSIDERATIONS $\quad . \quad$. $\quad . \quad$. 8.10

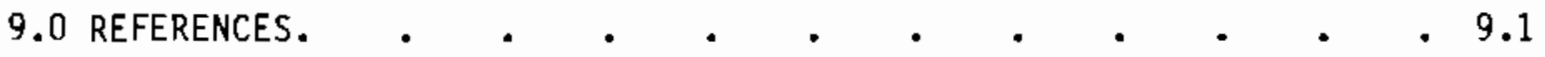

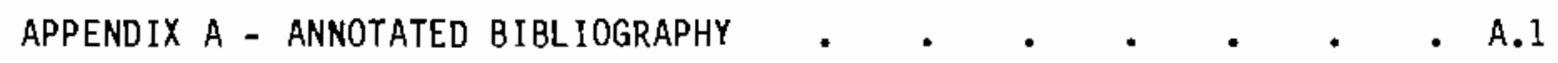

APPENDIX B - PERSONAL COMPUTER MODELS FOR EVALUATING

ALTERNATIVE FINANCING FOR SOLAR THERMAL

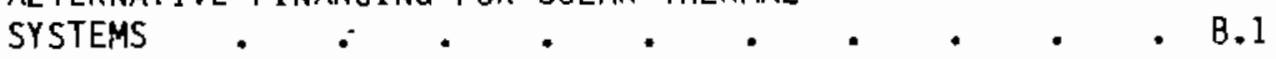




\section{FIGURES}

3.1 Major Parties in Financing Transactions . . . . . 3.1

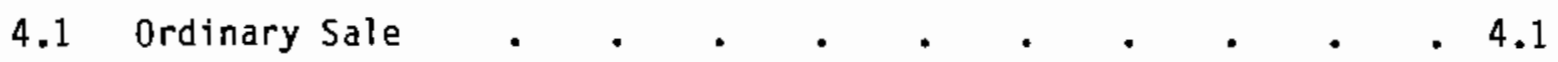

4.2 Sale with Borrowed Financing . . . . . . . . 4.2

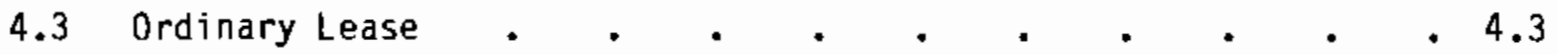

4.4 Third-Party Lease. . . . . . . . . . . . 4.3

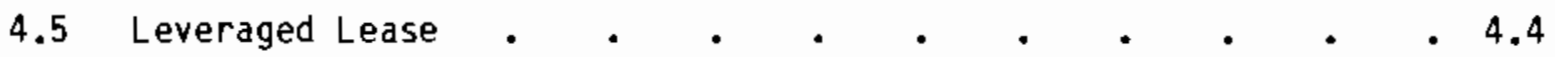

4.6 Sale-Leaseback ("Safe Harbor" Lease) . • . . . . 4.7

4.7 R\&D Limited Partnership . . . . . . . . . 4.10

4.8 Industrial Revenue Bonds . . . . . . . . . 4.11

5.1 Annual Cash Flows. . . . . . . . . . . 5.5

5.2 Large Negative Cash Flows Late in Project Life . . . . 5.10 


\section{TABLES}

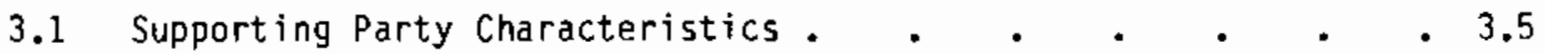

5.1 Percent Deductible from First Year Tax Liability . . . 5.8

5.2 Hypothetical Cash Flows . . . . . . . . . . . . 5.13

5.3 Discount Rate Versus Present Value of a Project . . . . 5.13

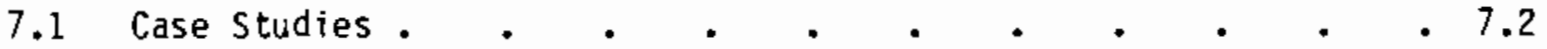

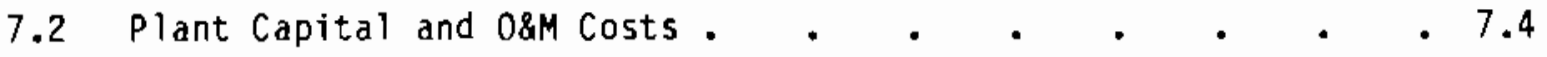

7.3 Tax Rates for Solar Thermal Case Studies . . . . . 7.5

7.4 Discount Rates for Case Study Organizations . . . . . 7.7

7.5 Cash Flow Analysis for Sale with Borrowed Financing . • 7.9

7.6 Cash Flow Analysis for Third-Party Lease-Owner . • . . 7.11

7.7 Cash Flow Analysis for Third-Party Lease-User . . . . 7.12 .

7.8 Cash Flow Analysis for Leveraged Lease-Dwner . . . . . 7.14

7.9 Cash Flow Analysis for Leveraged Lease-User • • • 7.15

7.10 Cash Flow Analysis for Sale-Leaseback User . . . . . . 7.17

7.11 Cash Flow Analysis for Sale-Leaseback Owner . • • . 7.18

7.12 Cash Flow Analysis for Industrial Revenue Bond . . . . 7.20

B.1 Standard Model Display Format . . . . . . . . . B.13

B.2 Standard Model Cell Contents - Supercalc Version . . . B.14

B.3 Standard Model Cell Contents - Visicalc Version . . . . B.23

B.4 Model Display Format for Sale-Leaseback User Case . . . B.36

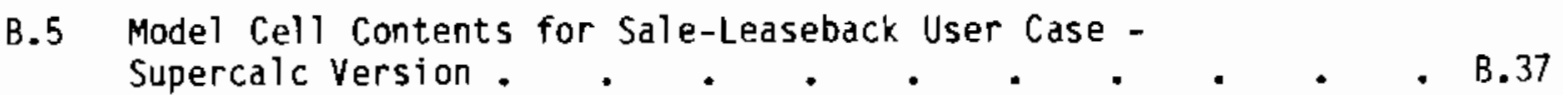

B.6 Model Cell Contents for Sale-Leaseback User Case -
Visicalc Version . . . . . . . . . . . . B.46 


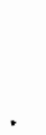


SOLAR THERMAL FINANCING GUIDEBOOK

\subsection{INTRODUCTION}

Solar thermal systems for producing either process heat or electricity have become increasingly attractive in recent years. This increase in economic attractiveness is due to a number of factors including cost and availability of conventional energy sources, improvements in solar system design and cost, and changes in tax laws relating to solar thermal investments. The cost-effectiveness of a new solar thermal system can be enhanced by using a financing arrangement strategy with the proper configuration of elements and parties. This guidebook describes alternative financing arrangements that could be used to develop solar thermal systems.

This guidebook is designed to meet three objectives:

- to aid solar thermal manufacturers, users, financial institutions, and other parties in the creation of financial arrangements that take optimal advantage of the possibilities for savings

- to bridge the gaps between various institutions and individuals in their knowledge of guidelines for using various financing alternatives

- to assist the solar thermal industry in identifying opportunities among solar thermal manufacturers, users, and intermediaries for solar thermal development.

Recent tax law changes have greatly increased the importance of investigating alternative financing options for solar thermal systems. Because the ability to qualify for (or make effective use of) various tax incentives varies greatly between individuals, arrangements other than an ordinary sale may greatly enchance project economics in some cases. Alternative arrangements, such as a third-party lease, can allow the tax incentives to be effectively used by one party in the transaction, who can then make the solar system available to the system user at a price that has been lowered because of the tax incentives. 
Although current tax laws provide a strong incentive for investigating alternative financing of solar thermal systems, tax incentives are not the only aspect that can make alternative financing attractive to an individual. Alternative financing packages are also attractive to help match capital investment requirements, expected rate of return on investment, and the amount of risk to the needs of each participant in the package. As an example, a company with high energy costs may be interested in acquiring a solar thermal system, but would like to minimize risks inherent in investing in new technologies. They might be able to acquire use of a solar thermal systen through lease arrangements with a group of entrepreneurs, who would be willing to accept the risk of building and operating the solar plant in compensation for a higher rate of return.

The discussion of financing alternatives in this guidebook is based on the concepts of net present value and risk versus rate of return. The net present value concept is important because it provides a means of assessing the value of projects where cash inflows and outflows occur in different amounts over a period of time. Because of the time value of money, such cash flows cannot simply be added to obtain a measure of project profitability. The present value concept solves this problem by providing a method to equate cash flows occurring in different time periods to equivalent cash flows occurring in the present. The risk versus rate of return concept is important because it helps to explain why different investors with equal resources will not always prefer the same project or financing alternative. This concept focuses attention on the trade-offs financial managers must make between the expected rate of return and the degree of risk that must be borne to realize the expected return. Generally, higher returns can be achieved only by accepting a higher level of risk. Consequently, investors must decide how much predicted return they require to induce then to face a particular level of risk. Some investors will prefer to minimize risk even if the associated return is low. Others will be willing to accept a higher level of risk in order to increase their expected return.

The elements and parties that could potentially be involved in alternative financing arrangements are discussed in Chapters 2.0 and 3.0 of this guidebook. 
These elements and parties are combined into example alternative financing packages. Chapter 4.0 identifies the laws, tax issues, industry practices, and potential participants associated with each package. Chapter 5.0 describes economic concerns in evaluating solar thermal investments, and discusses several methods for evaluating the economic attractiveness of participating in alternative financing arrangements. A financial methodology developed for evaluating alternative financing is presented in Chapter 6.0 , with examples of the analysis included in Chapter 7.0. The advantages and disadvantages of alternative financing arrangements are discussed in Chapter 8.0, which provides guidelines for participation in these arrangements, and presents an outline for developing and writing a sound proposal. An annotated bibliography and documentation of the personal computer model are included in the appendices.

This guidebook is not designed to develop a complete understanding of financing arrangements or solar thermal technologies. Instead, it introduces the elements and parties that might be involved in transactions surrounding solar thermal technologies by presenting definitions and examples of each element and party as well as sample arrangements that might be established. The readers of this guidebook should gain an understanding of the questions to ask and who might have answers when they are considering alternative financing mechanisms for a particular solar thermal technology.

Users of this guidebook should be cautioned that information regarding specific tax effects, costs of solar systems, and energy sales prices is provided for illustative purposes only. Investors should develop their own economic parameters and cash flow estimates to assess solar thermal projects. As is described in the guidebook, the tax implications of the financing arrangements are extremely important, making it imperative that individuals considering investing in solar thermal systems obtain qualified tax advice with regard to both current tax law interpretations and to their own tax situation. Although every effort was made to provide accurate information in this guidebook and reasonable numerical illustrations, many of the tax considerations are quite complicated, and subject to change. 


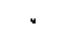




\subsection{ELEMENTS OF ALTERNATIVE FINANCING}

A11 arrangements for financing solar thermal systems can be generalized as consisting of a combination of elements and parties. The elements are factors such as sources of capital, insurance provisions, and incentives. The parties are individuals or companies actually involved in the transaction, and could include manufacturers, plant owners, lenders, plant lessees, and others. Since there are many elements and parties, all of which can be combined in a number of ways, the total number of alternatives available can become quite large. Therefore, this guidebook will discuss each of the elements and parties separately. Elements of the financial arrangements are described in this chapter, and the parties that might be involved are described in Chapter 3.0. Chapter 4.0 then integrates the elements and parties into a number of example packages that could be arranged.

If the financial aid to a particular transaction is provided by the private sector, it can be one of four types. The major alternatives include

- equity--the provision of money or other goods and services in return for partial ownership

- debt--the provision of resources, usually money, in return for a promise to repay the amount advanced plus interest

- grants--the unconditional provision of money, goods, or services

- insurance (or guarantees)--the promise to pay, usualiy money, if specific circumstances arise, usually in return for an advance fee.

Each of these four types has many forms, a number of which are discussed in this chapter.

On the pubiic side, a public agency could also provide those four types of financial aid. In addition, the public sector could help in two other ways that are not strictly financial aid:

- tax incentives--the promise of reductions in tax liability if certain activities are undertaken

- regulation--a government requirement that a transaction must take place, backed up with the threat of fine or imprisonment. 
Sometimes the requirement may state that a competing transaction cannot take place. Various types of each of these categories of financial aid and even more combinations of them are possible. These are also described in this chapter.

\subsection{EQUITY}

A party provides equity when it offers money or other goods and services in return for partial ownership of the organization or project receiving the money or other items of value. In corporations, equity financing is obtained by selling shares of stock to individuals and others. In the ordinary case, the shareholders receive common stock that gives them voting power over the hiring of officers and the disposing of assets as well as the right to receive dividends if they are paid by the corporation. In some cases, the shareholders receive preferred stock, which usually gives them a greater right to receive dividends, but does not include the right to vote on some matters.

In partnerships, equity financing is provided by partnership agreements. The proportion of the partnership owned by a particular party is often called units or shares; however, these differ from shares of stock. For example, limited partners may be like holders of preferred stock in that they have little or no right to vote on matters of partnership conduct.

Payments to those who have provided equity financing usually take the form of cash dividends, but they may also take the form of additional shares in the company or partnership, rights to buy additional shares (often called warranty or stock options), or royalty payments stemming from the use of the firm's assets.

Equity financing can be characterized in at least three ways. First, by the right granted to receive payments for the use of the money or other value provided to the firm. Holders of common stock and limited partners usually have very little guaranteed right to recejve such payments; others may have more rights. Second, equity financing can be characterized by the amount of ownership control it contains. Some providers of equity financing can exert a great deal of control over the operations of the corporation or partinership, such as the election of officers and the approval of major decisions; others 
can exert very little direct control. A third way to characterize equity financing is according to whether it was obtained through a private or public offering. This distinction is important because the Securities Exchange Commission attaches many conditions to the ways in which offerings can be made to the public.

Equity financing is apt to be crucial to solar thermal development. In general, the risks posed by any new technology such as solar thermal are such that sources that provide debt are more interested in less risky projects. The investments required of solar thermal projects are sufficiently large so that grants or tax credits are inadequate. The difficulty is that potential investors have other investment opportunities, notably in real estate, genetic engineering, and electronics, that may promise much higher rates of return for comparable risks.

\subsection{DEBT}

Debt financing is the loaning of money from one party to another, with the expectation that the receiving party will pay back the amount loaned, plus additional payments called interest. Most people are familiar with the most common forms of debt financing. However, debt can be characterized in a number of ways. Through variations in each of those characteristics, a very large number of different types of debt financing are possible. The characteristics and how they might vary are described below:

\subsubsection{Maturity}

Maturity refers to the amount of time before full repayment of the debt is due. Debt that is due in less than 1 year is characterized as short-term, or unfunded debt. Debt that can be repaid in more than a year from the date of issue is long-term or funded debt (Brealey and Myers 1981; D'Ambrosio and Hodges 1981). Given the construction lead times for most solar thermal technologies, long-term or funded debt is probably more important than short-term debt.

\subsubsection{Repayment Provision}

Repayment provisions are the packages made for returning the principal of a debt. Although long-term loans may be repaid in one payment on the date of 
maturity, they are usually repaid in a series of steady payments. The gradual retirement of bonds is often done through a sinking fund. The firm makes annual cash payments into the fund, from which the bonds are repurchased. Many borrowers also have a call provision that provides the option to repay the bonds in the issue before maturity, according to a specified premium above their face value (Brealey and Myers 1981; D'Ambrosio and Hodges 1981). Again, the long-term nature of most solar thermal projects would ordinarily lead to fairly even payments throughout the life of the solar thermal system.

\subsubsection{Seniority}

Seniority refers to the priority status a lender is assigned for being paid by the firm in the event of bankruptcy. Some debt instruments are subordinated to junior status. If bankruptcy occurs, all senior debt must be fully paid before subordinated lenders holding junior claims can receive payment, although in practice bankruptcy courts will usually give at least a little to everyone (Brealey and Myers; D'Ambrosio and Hodges 1981).

Most solar thermal manufacturers are quite willing to grant high seniority to debts to finance solar thermal systems. However, manufacturers that are subsidiaries of larger corporations, and users (such as utilities or large industrial firms) for whom the system would be a small part of their plant and equipment, have difficulty granting a high seniority to solar system debt.

\subsubsection{Security}

Security is the protection a creditor claims on certain types of assets. In a default situation, debt with a security claim on certain assets, such as land or buildings, can take title to (ownership of) those assets. Long-term secured claims are often called mortgages. Bonds are often secured through mortgages on equipment. Long-term claims that are unsecured are sometimes called debentures. If a firm goes bankrupt, bondholders have first claim on mortgaged assets, while investors with debentures have a junior claim on mortgaged assets and a senior claim on unmortgaged assets (Brealey and Meyers 1981).

Those involved in solar thermal system development are usually quite willing to grant any lender a security interest in the solar thermal syster itself. However, to date, most lenders have felt that the system has little 
use outside of its planned situation, so they do not believe that security interest gives them much protection in the event of a default by one of the parties involved.

\subsubsection{Interest Rates}

Floating and fixed rates are the alternative types of interest rates in a loan agreement. In the case of a fixed rate, the interest rate on the debt is established when the debt is issued, and remains constant for the entire term of the loan. A floating rate, however, may fluctuate during the term of the loan according to a specified formula. For example, a bank may offer a loan at a certain percentage above the prime rate, so that the interest on the loan will change along with the prime rate (Brealey and Myers 1981 ).

The difference between fixed and floating rates on debt has not been an issue in discussions concerning financing for solar thermal systems.

\subsection{GRANTS}

Grants are provisions of money, goods, or services from one party to another, without the providing party expecting something in return from the receiving party. Generally, grants are made to enable the receiving party to undertake some activity it might not otherwise undertake. The granting party is usually seeking the public good rather than private gain from having that activity undertaken.

Such a method of providing aid is rare among two private parties, but not unknown. Foundations are the principal exception, as they make grants to various organizations in order to carry out activities. In addition, large corporations will sometimes make grants to smaller organizations for particular purposes. However, such private grants are usually most directly involved with some public activity, and would not be involved in the production of a largely pivate good such as a solar thermal installation.

The federal government frequently makes grants. These grants may be in the form of either lump-sum transfers early in a project life to pay for its construction, or iten-by-item subsidies to induce the production of an item and keep its price low. Sometimes such monies are first disbursed to state or local governments, which will then make the actual grants. 
The federal government at one time made grants for alternative energy development. However the current administration is rapidly removing the government as a provider of this form of assistance. In addition, the amounts of money required are large enough so that the much smaller grants available from foundations or state or local governments are apt to be used in situations in which they pay for a greater proportion of the costs than they would for a solar thermal system. In other words, grants are not a likely source of financing for solar thermal power.

\subsection{INSURANCE}

Another form of potential support is insurance. Insurance is the promise to pay some item of value, usually money, if specific circumstances arise. Generally, the party that promises to pay under the specific circumstances, if it is private, receives money or some other item of value in advance. Insurance companies obviously provide this kind of support, but they are not the only ones. Bonding companies provide a similar resource, as do cosigners on a note and those that otherwise guarantee a loan.

As will be discussed below, such contingent resources can be very useful, particularly in inducing parties very sensitive to risk to provide resources in the form of debt, either at lower interest rates or to organizations they might not otherwise consider.

At least one expert involved in discussions surrounding solar thermal development financing, Charles Wilde (Wilde and Dickinson 1981), believed that federal loan guarantees were absolutely essential to induce bank debt so that his proposed financial packages could be put together. In his view, the advantage of such a guarantee was not that the banks would then loan money at a lower rate of interest, but that the banks would consider loaning any money at a reasonable rate of interest.

\subsection{TAX INCENTIVES}

Obviously, taxation resources can be provided only by a government, whether local, state, or federal. Usually they come in the form of provisions from the federal government that reduce a company's liability for federal 
income tax if it undertakes certain activities. These provisions usually relate to the amount that can be subtracted from gross income as a deduction for business expense, and over what period of time; or the amount that can be subtracted from income tax liability as a credit, and over what period of time. For instance, the federal government allows credits (deductions directly from tax liability) for certain kinds of energy investments [Internal Revenue Code Sec. 46(a)(2)(c)(i)] and certain increases in research and development expenditures [Internal Revenue Code Sec. 44F(a)]. Other provisions regulate how much can be deducted from gross income as an expense for investment in plants and equipment [Internal Revenue code Sec. 46(a)(2)(B)].

As discussed in more detail in Chapter 4.0, the investment tax credit and the energy tax credit can make a significant.difference in cash flows for some financing packages. The changes in the depreciation rules established by the new accelerated cost recovery system [Internal Revenue Code Sec. 167, 168] also help improve cash flows, but they do so for potentially competing investments as well.

\subsection{REGULATIONS}

The government can also aid a transaction by imposing requirements through statutes, executive orders, or administrative regulations. These requirements can be a powerful incentive or disincentive to particular transactions. Generally, they operate so as to be a disincentive to certain transactions, thus becoming a form of incentive for the transactions that are competitive with those facing government requirements. For instance, government constraints on the use of oil and natural gas through the Powerplant and Industrial Fuel Use Act (P.L. 95-620), and government constraints on the use of coal through provisions of the Clean Air Act (P.L. 95-95) may also be viewed as incentives for alternative forms of generating heat or electricity, including solar thermal installations. Of course, such incentives are indirect and difficult to evaluate in quantitative financial terms. As a consequence, they are not considered explicitly in the rest of this guidebook. Note, however, that their potential value is quite large and that a myriad of other reports have addressed the subject explicitly (Cole and Tegeler 1980). 


\section{-}




\subsection{PARTIES TO ALTERNATIVE FINANCING}

This chapter discusses the parties that might participate in an alternative financing arrangement. Each party is described by a number of common dimensions so they can be compared and contrasted.

Figure 3.1 shows ways in which parties can be involved in alternative financing. The figure shows the two essential parties to any transaction--the buyer and the seller. It then shows the types of financial aid that might provide various benefits to either the buyer or seller. It also shows what has been called, for the purposes of this report, "third parties"--other institutions that may intervene in the transaction between the buyer and seller, as opposed to working through either one of them. A third party is somewhat like a wholesaler who buys from the seller and then sells to the buyer. All of the likely alternative financing arrangements for solar thermal systems involve different combinations of these three parties and those supporting them.
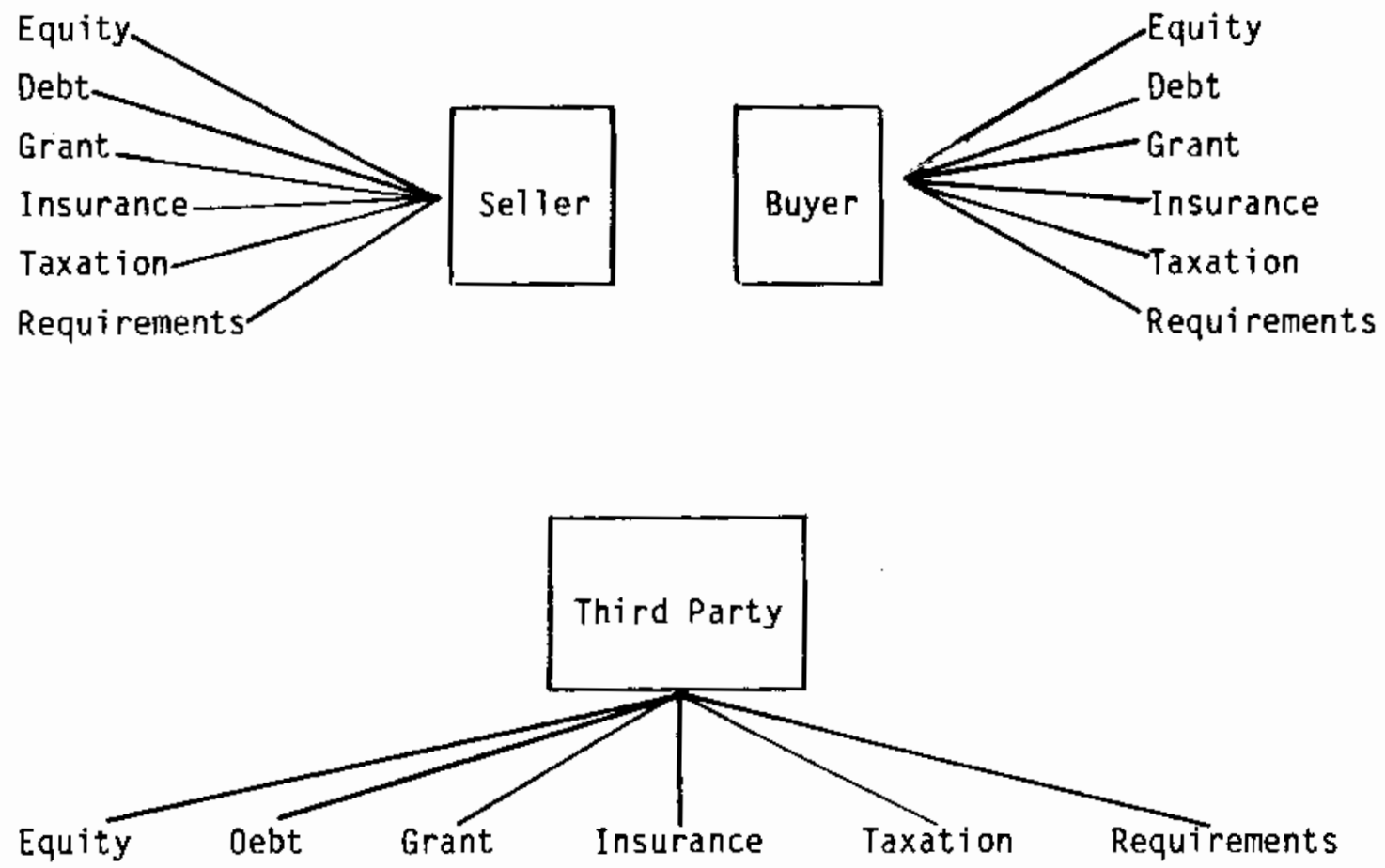

Figure 3.1 Major Parties in Financing Transactions 


\subsection{SELLERS}

In most cases, the seller involved in a solar thermal transaction will be the manufacturer of solar thermal equipment such as heliostats or parabolic troughs. The specific items sold can vary; most analyses assume that sales consist of a solar thermal plant or installation comprising collectors such as heliostats or parabolic troughs and the other machinery (e.g. piping, wiring) necessary to make the plant or installation deliver heat or electricity.

of course, variations are possible. At one extreme, the solar thermal manufacturer could sell collectors to a second party who would then assemble them into an installation or plant. At the other extreme, the solar thermal manufacturer could sell the heat or electricity produced by a solar thermal installation. The base case in this guidebook is a solar thermal manufacturer selling completed plants. However, other variations will be explored as well.

\subsection{BUYERS}

The reference case for this report assumes that the buyer is an industrial concern or a utility that buys a solar thermal plant to generate heat or electricity for its own operations. However, this reference case contains four major variants--a utility versus an industrial concern, and a primary interest in heat versus a primary interest in electricity.

For a utility, the distinction between heat and electricity relates to the amount of the plant purchased from the solar thermal manufacturer. One option would be for the utility to buy and construct the solar plant as a complete electrical generation unit. An alternative would be a repowering type project in which the solar plant provides process heat to an existing fossil fuel plant and reduces the amount of expensive fossit fuel required.

An industrial concern will almost always use the heat for various industrial processes such as food drying, and may also generate and use electricity cogenerated from the same installation.

Again, variations beyond these four are possible. At one extreme, the utility or industry would buy the components and assemble the plant or installation. At the other extreme, it would buy only the heat or electricity delivered 
from such a plant or installation. In the reference case, the user will buy a completed plant that it will operate.

\subsection{THIRD PARTIES}

Third-party financing is a subset of alternative financing. It occurs when the item sold by the solar thermal manufacturer is not the item purchased by the utility or industrial concern. Instead an intermediary (third) party buys what the solar thermal manufacturer is selling and converts it into what the utility or industrial concern is buying. The reference third-party example will be an intermediary that buys a completed plant or installation from a solar thermal manufacturer and, in turn, sells the heat or electricity generated by that plant to a utility or an industrial concern.

In this reference case, the intermediary will be either active or passive. First, an active third party could be an energy management company, as is discussed below. Such a company is in the business of generating energy in one form or another and is most analogous to a mini-utility, although its customer is often a more normal publicly or privately owned utility. In passive third-party financing, the third.party owns the plant or installation, but does not operate it. It may lease the plant to an energy management company, or even back to the original solar thermal manufacturer for actual operations.

\subsection{SUPPORTING PARTIES}

The buyer, seller, or any third party may obtain financial and other support for its activities from each of a host of other parties. In this guidebook, these parties are called "supporting" because they deal with only one of the major parties at a time. Supporting parties include institutions that provide all of the types of support discussed in Chapter 3.0--equity, debt, grants, insurance, tax incentives, and regulations.

Each party that might be involved in financing solar thermal transactions is described systematically with respect to different dimensions of interest. These dimensions include: 
- risk/return tradeoff - whether the party prefers low risk even with a commensurately lower rate of return, or high return, even with a commensurately higher level or risk

- size - the amount that an individual party might be expected to contribute to an individual transaction

- participation - the interest of the party in ownership or other forms of control over the transaction

- solar thermal propensity - the already existing interest in solar thermal technologies for reasons other than strict economics, such as the contributions that such technologies might make to the natural environment or national security

- transaction costs - the time, money, and trouble involved in obtaining financing from a particular party that stem from the necessity to identify and pursuade that party, as well as compliance with government requirements associated with that party

- private versus public - whether the party is apt to be a private individual or organization or a public one

- individual versus organization - whether the party is a formal organization as opposed to an individual or group

- tax status - whether the party is subject to tax or not, and whether those interested in investing have income subject to taxation.

Table 3.1 provides a comparative summary of the supporting parties in terms of these dimensions. More detailed discussion of the supporting parties is presented in the following paragraphs.

\section{4 .1 Banks}

A bank is the most obvious place to start in a search for debt financing. The term "bank" includes commercial banks, savings and loan institutions, credit unions, and mutual savings associations. All of these institutions loan money to individuals and firms, and receive money from deposits of individuals and firms. Various state and federal regulations place constraints on both of these types of transactions, including interest rate constraints, loan-to-asset 
TABLE 3.1 Supporting Party Characteristics

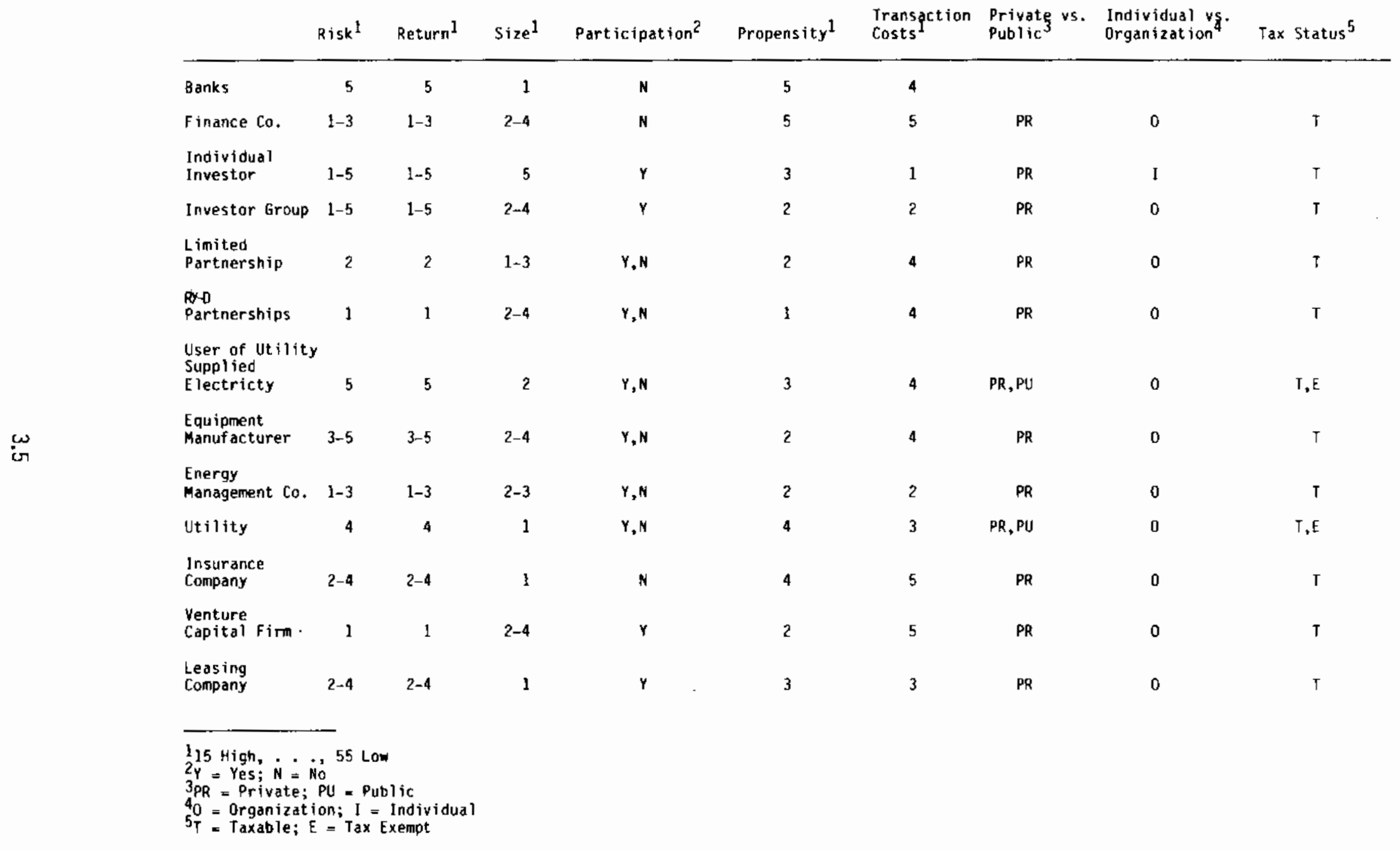


ratio constraints, and a variety of other requirements designed to protect depositors. As a result of the many regulations affecting banking operations, and as a result of the way these institutions have evolved over time, they can make loans in a variety of sizes ranging from the very small to very large. However, banks insist on rather low levels of risk, even if the rate of return is commensurately lower. Unlike those in Europe, banks in the United States do not usually participate in the ownership or management of the projects they finance unless the amounts loaned are very high. The banking community is not fully aware of the advantages and shortcomings of solar thermal technology. Transaction costs associated with a bank Toan are relatively low. Most banking institutions are private, although some credit unions located in the public sector might be approached for loans. By definition, banks are organizations; their tax status depends on whether they are credit unions or another type of banking institution. Banks may also have a subsidiary that functions as a venture capital firm (discussed below), using their earnings from interest payments and other sources rather than funds from depositors.

\subsubsection{Finance Companies}

A finance company is a lending institution that loans its own funds, but does not seek or lend deposits of others. Finance companies are traditionally the "banker of last resort" for the household sector, and they may participate in riskier loans to firms as we11. Thus, the acceptable level of risk and the commensurate level of return are higher for a finance company than for a bank. The size of loan in which a typical finance company can participate is usually smaller than that of a bank in the same community. Finance companies, like banks, generally do not participate in the management of the projects they finance. Propensity of finance companies to engage in loans for solar thermal projects is probably lower than for banks because of the lack of knowledge about solar thermal technologies and economics. Transaction costs should be low, as in the case of banks. Finance companies are private organizations and are taxable if they show a profit.

\subsubsection{Individual Investors and Investor Groups}

Individuals or groups of individuals who invest in firms offer a source of capital willing to face higher risk levels in order to earn commensurately 
higher rates of return than is possible from banks. For individual investors, the size of transactions that could be financed would typically be lower than for groups, although there is enormous variation in this area. Some very wealthy individuals may represent larger sources of capital than several less wealthy individuals who pool their resources. Both individuals and groups may occasionally desire some participation in the ownership and management of the project; if these individuals or groups are knowledgeable about solar thermal technologies, their propensity to invest may be moderate to high. However, these individuals may have more attractive opportunities elsewhere at similar risk levels. The transaction costs of dealing with an individual investor should be quite low, once the willing investor is identified, and fairly low for groups, as well. However, when these costs are added together from all the groups or individuals necessary for a large project, the total transaction costs may be quite high. If the number of individual investors contacted is greater than a limited number (usually around 30), both the state and federal governments may impose strict procedural requirements on the process of raising funds. Both individuals and groups are, by definition, private sector entities and, as such, taxable. The tax status of each individual or group can also vary widely. However, if the individual or group is interested in investing, the investor is usually in the $50 \%$ income tax bracket and has income that is not currently sheltered by a deduction or tax credit.

\subsubsection{Limited Partnerships}

A partnership is one in which a series of individuals or groups share in the ownership of a company or project. A limited partnership is a special form in which at least one of the partners is a general partner whose entire assets are pledged to support the partnership, and others are limited partners who pledge only the assets they have already invested in the partnership. Usually a general partner will be a corporation of some sort, and the limited partners will be individuals or groups.

Limited partnerships may be able to accept relatively high risks at a high rate of return, especially since the risks borne by members of the partnership are restricted due to the form of the partnership agreement. The size of transaction that can be financed differs greatly, depending on the resources put 
into the partnership. Ownership and management participation may or may not be desirable for a given partnership, and propensity to invest in solar thermal is probably relatively high, limited only by other opportunities available to the partnership. Transaction costs should be quite low for such a group. Limited paratnerships are, by definition, private sector groups and have a taxable status.

\subsubsection{Research and Development Partnerships}

Research and Development (R\&D) partnerships are a special category of limited partnership in which an agreement is made solely for the purpose of engaging in research and development. These partnerships are discussed further in Chapter 4.D as one example of a financing arrangement. The acceptable risk and return levels for an R\&D partnership should be quite high, and the size of project that could be financed in this way could range from moderate to large. Ownership participation is a standard feature of these arrangements, and the propensity to invest in solar thermal technologies should be relatively high. Transaction costs for this arrangement are quite low and, by definition, the institution of an R\&D partnership is a private organization, which is taxable. 3.4.6 Industrial Users of Electricity and Heat

This category as defined for the guidebook includes the entire industrial sector of the economy except for those few firms generating all of their own electricity. Since few firms do this, there is a wide range of firms that might be conceivable sources of capital for solar thermal projects. If a firm is interested in using the output of a solar thermal plant for process heat needs or electricity requirements, it is quite reasonable to think of involving that firm in the financing arrangements. If a firm is currently a user of utility-supplied electricity, the level of risk it accepts would be relatively low, as would the rate of return from the project. Small to moderate projects could be financed in this way, and ownership participation should be a negotiable issue. The propensity of firms to invest in this sort of arrangement should be moderate, and the transaction cost should be relatively low. Both private and public entities are potential candidates for this type of financing, and both taxable and tax-exempt organizations could be approached. 


\subsubsection{Solar Thermal Equipment Manufacturers}

Firms that produce some part of a solar thermal plant have a vested interest in seeing that their equipment is widely used. Equipment manufacturers may be a source of capital especially for early applications that gain high visibility. The ability of a manufacturer to provide capital is probably higher if the manufacturer is a subsidiary of a larger firm. If a firm decides to invest in the necessary production capacity, it should also be willing to accept the level of risk and rate of return applicable to its investment decision. The size of solar thermal projects that could be financed in this way would be relatively small compared to the manufacturing plant, and ownership participation is probably a negotiable issue. The propensity of an equipment manufacturer to invest in an early, highly visible solar thermal project should be relatively high, and transaction costs should be low. Almost all equipment manufacturers are, by definition, taxable, private organizations.

\subsubsection{Energy Management Companies}

An energy management company is in the business of providing energy in some form to its user, and it may or may not own the energy source plant such as a solar thermal plant. Because an energy management company is presumed to be knowledgeable about the technology, its propensity to invest in the technology, and the level of risk and rate of return that it would accept, should be relatively high. The size of project that could be financed in this way varies. Transaction costs should be quite low. Energy management companies are likely to be private entities with a taxable status.

\section{4 .9 Utilities}

Both public and private utilities exist in the U.S. They range in size from small utilities serving small, rural communities, to large utilities holding companies serving metropolitan areas in several states. Consequently, it is difficult to make valid generalizations about this class of financing sources. The utility industry is generally thought to be risk averse and the rate of return necessary to interest such a utility is also relatively low. financial transactions with a utility vary from small to large and ownership participation is negotiable. The propensity of utilities to invest in solar 
thermal technologies is low for most utilities at the moment, although a few leaders in the industry are exploring this area at the present time. Transaction costs of dealing with the utility are moderate, due to the variety of regulations involved in utility operations and financing.

\subsubsection{Insurance Companies}

Insurance companies are major sources of investment capital in the U.S. economy. They are large, diverse investors who can accept high levels of risk at a high expected return for a portion of their investment portfolios. Their financial investments vary from smalt to very large. Management participation is generally not desirable for these firms, and their propensity to invest in solar thermal technologies is possibly low at present due to a limited knowledge base concerning solar thermal technologies. Transaction costs of dealing with an insurance company should be low. By definition, insurance companies are private organizations that are taxable.

\subsubsection{Venture Capital Firms}

Venture capital firms exist solely for the purpose of financing new, highrisk enterprises that promise extraordinary rates of return if they are successful. If solar thermal projects could promise a high return at the admittedly high levels of risk that exists, almost any size project could be financed, and the propensity of such firms to get into the solar thermal area could be rated as high. The problem has been that the high level of risk in solar thermal enterprises has not been matched by an expected rate of return high enough to compete with alternative opportunities for venture capital firms in areas such as microelectronics, genetic engineering, and other rapidly advancing technological areas. Transaction costs in dealing with venture capital firms should be low, and these organizations are private, taxable entities.

\subsubsection{Leasing Companies}

A leasing company specializes in buying equipment from a manufacturer and leasing it to a user. Leasing companies could conceivably become involved in solar thermal technologies if relatively portable and reusable technologies are involved. Leasing companies now include small and large automobile and truck leasing entities, and other organizations that lease such jtems as airplanes, 
railroad cars, and real estate. The sizes and types of entities involved in leasing vary from small groups of investors to very large corporations. Consequently, it is difficult to characterize the possible size of transactions. Leasing companies develop when a particular piece of equipment has a definite resale value after its leased use is completed. Hence, they are not likely to be used for solar thermal technologies until the industry is well established. When that happens, the acceptable level of risk for a leasing arrangement is likely to be moderate to low, with the commensurate rate of return. The size of transaction that could be financed in this way could vary greatly from small to large. Under these assumptions, the propensity to invest should be high, * and the transaction costs should be moderate. Leasing companies by definition are private, taxable organizations. 


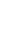




\subsection{EXAMPLE ALTERNATIVE FINANCING PACKAGES}

This chapter describes combinations of parties and elements that may be of interest in arranging financing for solar thermal technologies. Some of these arrangements are presented with a discussion of cash flows and other details that might be involved in particular case examples. Several of these financing packages are illustrated in more detail (including hypothetical cash flows and project evaluation) in Chapter 7.0 , following a discussion of project evaluation methodologies in Chapter 5.0 and modeling equations in Chapter 6.0 .

\subsection{ORDINARY SALE}

In an ordinary sale the user would receive the plant from the manufacturer in exchange for the purchase price, as shown in Figure 4.1. Such an arrangement is currently considered extremely unlikely because of the large amount of capital required to invest in a solar thermal facility, the risks involved, and the current projected rates of return.

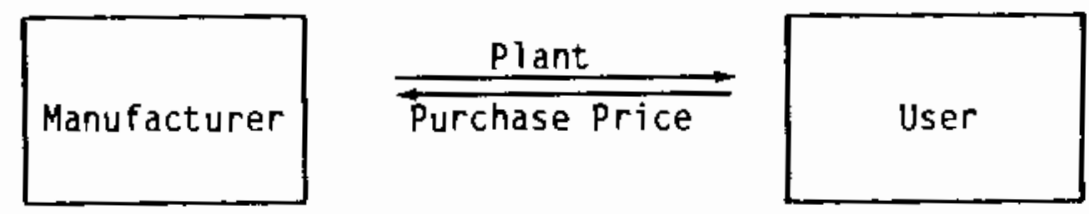

FIGURE 4.1 Ordinary Sale

\subsection{SALE WITH BORROWED FINANCING}

A sale with borrowed financing would involve a bank as a third party (see Figure 4.2). The user would take out a loan from the bank, usually for about $80 \%$ of the purchase price, to help finance the purchase of the plant from the manufacturer. The user would repay the loan with interest. For large installations, the sale of a solar thermal facility using borrowed bank financing is somewhat improbable, because of banks' relative disinterest in such an innovative energy project. 


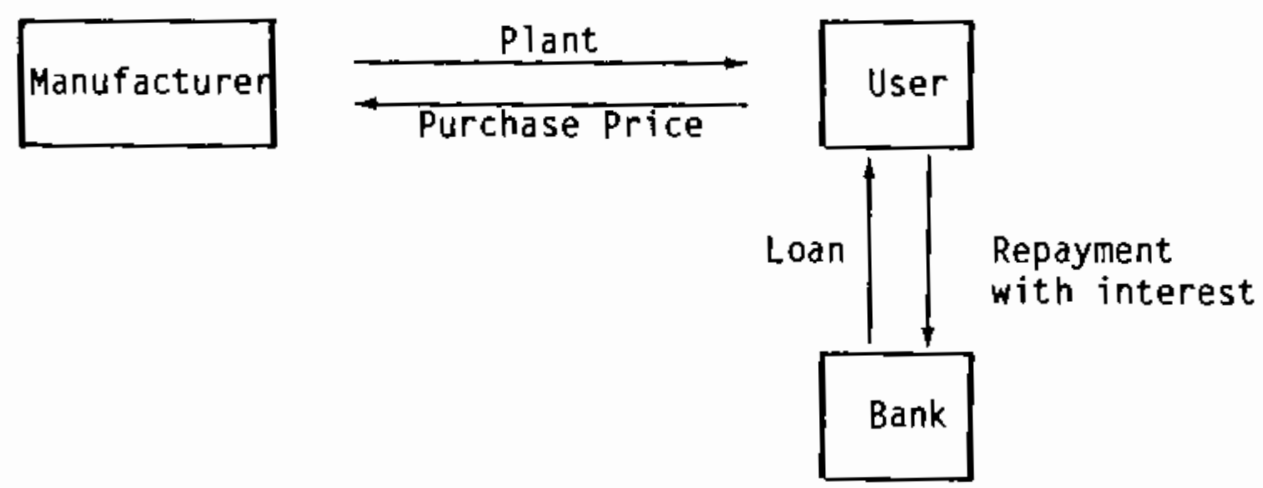

FIGURE 4.2. Sale With Borrowed Financing

\subsection{LEASING}

A lease is a rental agreement in which the user of a piece of equipment or a plant (lessee) promises to make a series of payments to the equipment or plant owner (lessor). At the end of the lease term, the lessee has the option to purchase the equipment or negotiate a new lease. The lessor obtains the tax benefits of ownership during the lease term, and can pass these savings onto the lessee through lower lease payments (Brealey and Myers 1981, p. 521; Klepper, Sherman and Carroll 1982, p. 235).

Leasing provides various advantages to both the owner/lessor and the user/ lessee. Lessor advantages are availability of accelerated depreciation to amortize costs; applicable investment and energy tax credits; and the residual value of the equipment (Klepper, Sherman and Carroll 1982). Lessee advantages are 100\% financing (no capital requirement); the possibility of lower payments than in a bank loan, if the value of tax benefits is passed on; the lessee's net worth is not directly decreased because of off-balance sheet financing; and payments and length of lease term are flexible (Klepper, Sherman and Carroli 1982).

Leasing offers particular tax advantages in the case of solar thermal financing. In a typical arrangement, a corporate investor would buy and finance the solar thermal equipment and lease it to a utility. The utility could realize significant savings if the tax credits available to the corporation were passed on through lower lease payments. Applicable tax benefits include the $10 \%$ investment tax credit [Internal Revenue Code Sec. 46(a)(2)(b)], 
15\% energy tax credit [Internal Revenue Code Sec. 42(a)(2)(C)(i)], accelerated depreciation of the equipment [Internal Revenue Code Sec. 167, 168], and possible state energy tax credits.

\subsubsection{Ordinary Lease}

In a simple, ordinary lease involving only two parties, the user would agree to make regular lease payments to the manufacturer in return for use of the facility as shown in Figure 4.3. A leasing arrangement operating directly between the manufacturer and user is unlikely. Usually, a third party is likely to be involved in the lease transaction.

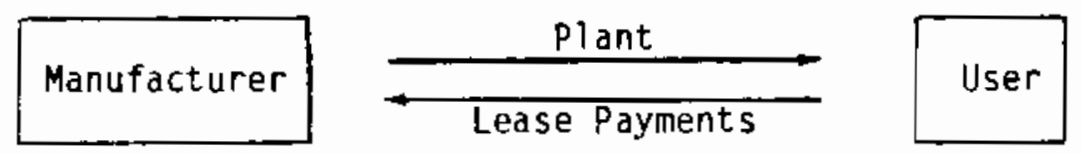

FIGURE 4.3. Ordinary Lease

\subsubsection{Third-Party Lease}

A financing lease normally would involve three parties: the manufacturer, the user, and the owner, who acts as the third party. In this arrangement, shown in Figure 4.4, the owner, most likely a corporate investor, would purchase the plant from the manufacturer, and then arrange to lease it to the user in exchange for regular payments. The owner/lessor would receive tax credits, including depreciation, the investment tax credit, and energy tax

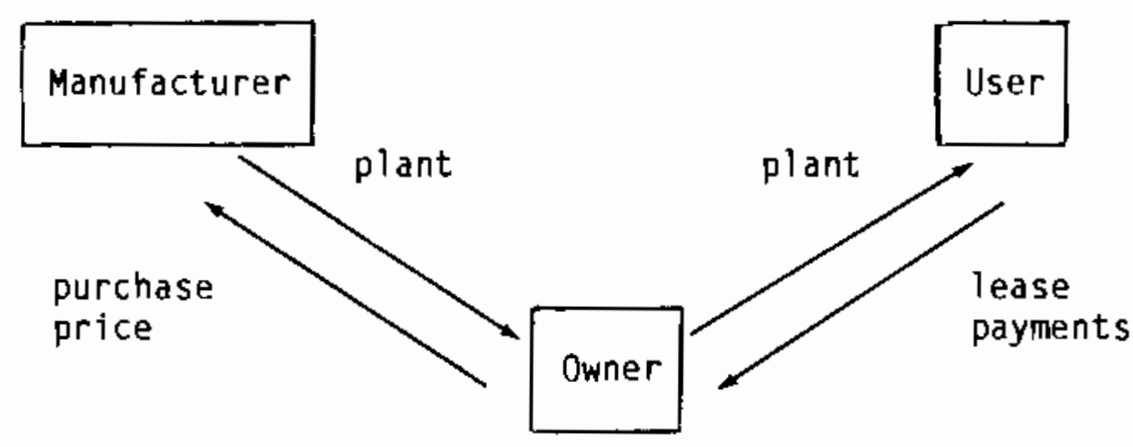

FIGURE 4.4. Third-Party Lease 
credit. These tax benefits might be passed on to to the user/lessee in the form of reduced lease payments.

\subsubsection{Leveraged Leasing}

In leveraged leasing, part of the cost of the leased asset is financed through a loan secured by the asset and lease payments. The lessor issues debt and equity claims against the asset and Tease payments (Brealey and Myers $1981)$.

The leveraged lease is illustrated in Figure 4.5. The owner (lessor) is the intermediary among all the parties involved. The prospective owner raises the majority of the capital needed to buy the plant by taking out a loan (usually comprising about $80 \%$ of the purchase price). The remaining capital is in

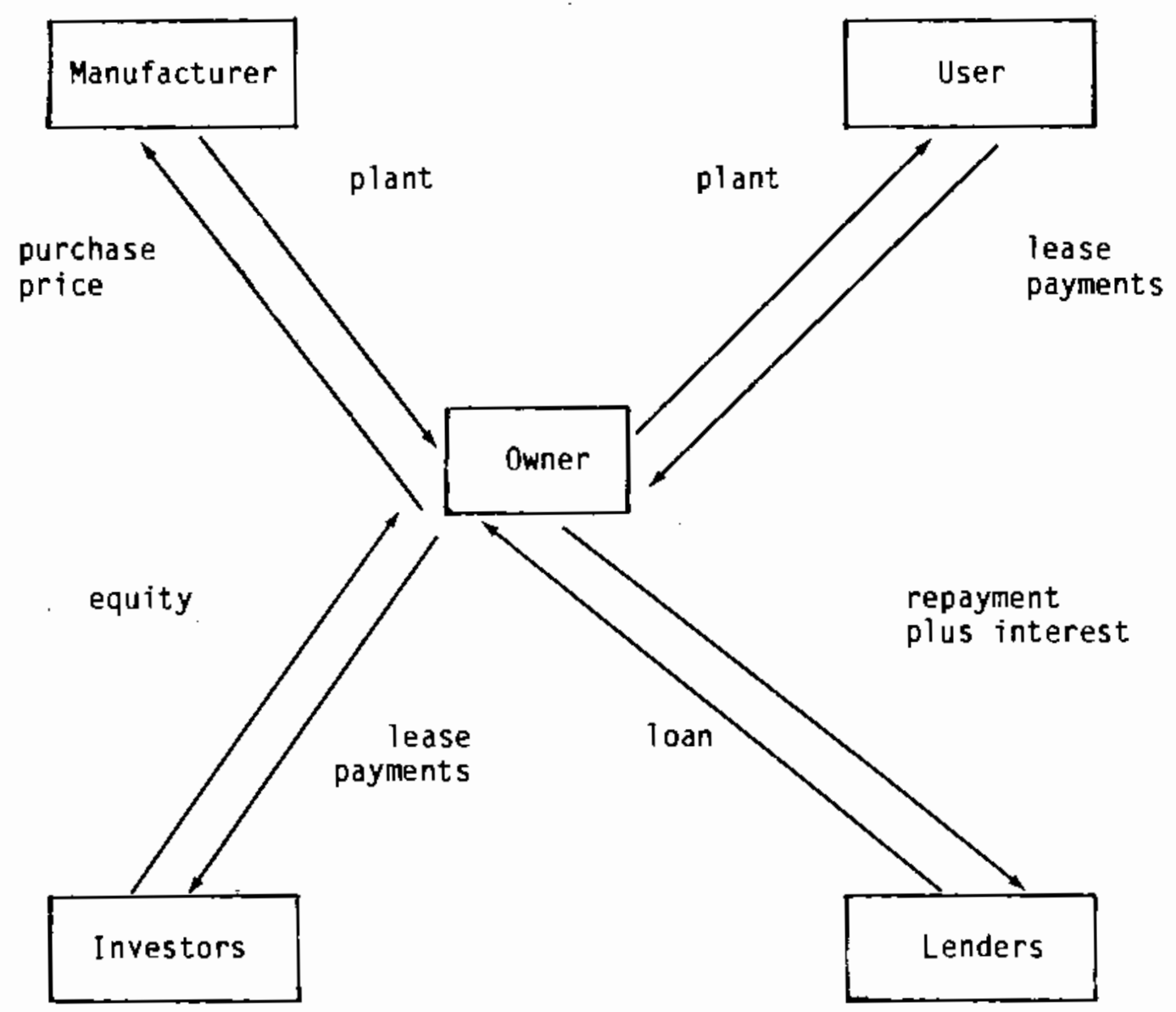

FIGURE 4.5. Leveraged Lease

4.4 
the foria of equity, which may be contributed by investors. After purchasing the plant, the owner makes a lease agreement with the user, and receives regular lease payments. The lenders have a security interest in the leasing contract. The lease payments received by the owner/lessor are used to repay the lenders. The amount left over after repaying the loan and interest is distributed to the equity investors. Tax benefits received by the lessor (depreciation, investment tax credit, energy tax credit) are also passed on to the investors (Klepper, Sherman and Carroli 1982; Brealey and Meyers 1981).

Leveraged leasing offers several advantages to the owner/lessor. Obtainment of the available tax credit helps provide a return on the investment. The lease payments received give the lessor a regular cash return as well as to help pay the debt on the loan. The cash return provides the opportunity for tax benefits through deductions for accelerated depreciation and interest on the loan. Although the lessor has invested only a small fraction of the equipment cost, the entire cost can be depreciated (Klepper, Sherman and Carroll 1982).

\subsubsection{Sale-Leaseback Method}

Under the Economic Recovery Tax Act of 1981 (P.L. 97-34), companies previously unable to take advantage of investment tax credits may be allowed these benefits through sale-leaseback financing (sometimes called "safe harbor leases"). In the sale-leaseback method, a company that cannot benefit from tax credits sells equipment and/or property to a company that can benefit from such credits. The buyer company then leases the property back to the first owner under contract. The lessor (the equipment owner) and the lessee (the equipment user) are then able to share in the tax benefits allowed to the lessor.

The sale-leaseback arrangement is more feasible than normal leasing because the financial risk to the lessor is significantly reduced. Under conventional arrangements, the lessor has a major at-risk investment in the property. Under sale-leaseback, the lessee invests in the property and therefore is accountable for most of the at-risk investment that would have been the burden of the lessor. 
Because the U.S. Treasury Department interpretation of the law is uncertain, a company's ability to make use of sale-leaseback arrangements will ultimately depend on final guidelines to be issued by the Internal Revenue Service (IRS). Although these guidelines are still undetermined, interim Treasury Department guidelines are found in the IRS "safe harbor" provisions [Internal Revenue Code Sec. $168(8)(B)]$. There are three basic requirements: (1) the lessor must be a "regular corporation"; (2) the lessor's minimum investment in the leased property must never be less than $10 \%$ of the property's cost (25\% for energy property); and (3) the term of the lease, including extensions, must not exceed $90 \%$ of the property's useful 1 ife for depreciation purposes, or $150 \%$ of the present class life of the property. An additional requirement is that the lessor must buy the property within 3 months of the lessee's original purchase.

If the final IRS rules do not impose further major restrictions on the use of sale-leaseback arrangements, manufacturers and utilities will have been provided with a major incentive to enter the solar thermal market. Available credits in a sale-leaseback arrangement for solar thermal financing include the $10 \%$ investment credit [Internal Revenue Code Sec. 46(a)(2)(B)], the 15\% energy tax credit [Internal Revenue Code Sec. 46(a)(2)(c)(i)], and a five-year depreciable life under the new Accelerated Cost Recovery System Internal Revenue Code Sec. 167,168 . If all of these credits could be utilized by the participating corporation, the project cost to the utility could be reduced by as much as $25 \%$, according to data provided by $R$. W. Vallario.

A sale-leaseback arrangement for solar thermal financing would involve two basic steps, shown in Figure 4.6. In the first step, the manufacturer or a utility buys and assembles the necessary equipment and property. A corporation rich in capital but needing tax reductions buys the plant from either the manufacturer or the utility. The seller receives a fraction of the entire plant cost (no less than $10 \%$, or $25 \%$ for energy property) in the form of a down payment. In the second step, the corporation leases the plant back to the seller (manufacturer or utility); the transaction is arranged so that the remaining purchase payments in Step 1 are exactly offset by the lease payments. Thus, no more cash is exchanged between the two parties. Following the leaseback transaction, the manufacturer can make arrangements to sell heat and electricity to 
Step 1
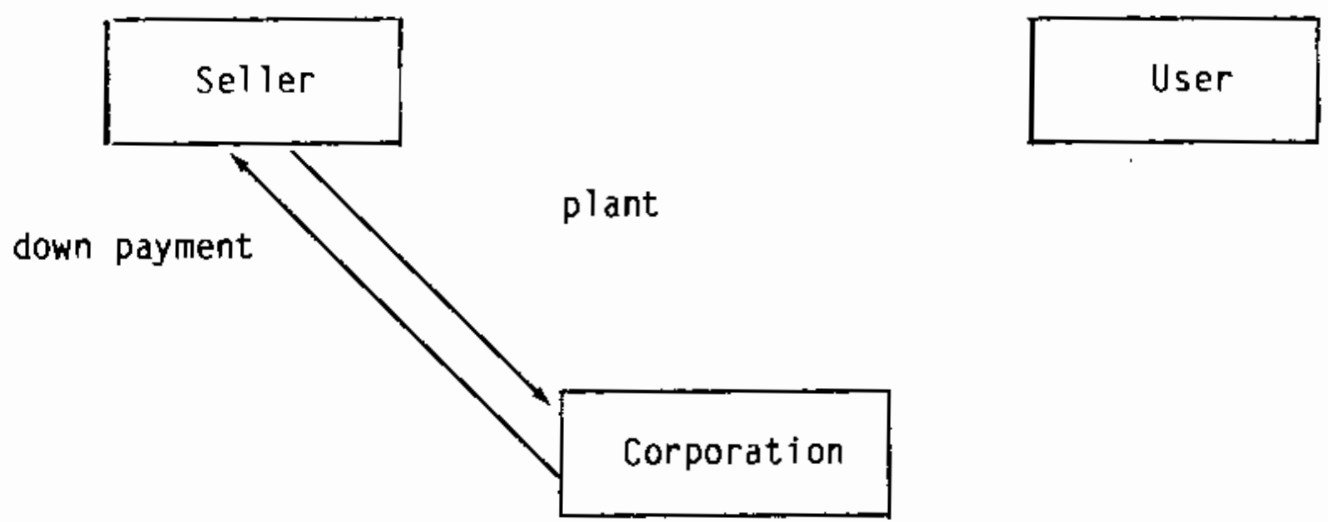

Step 2
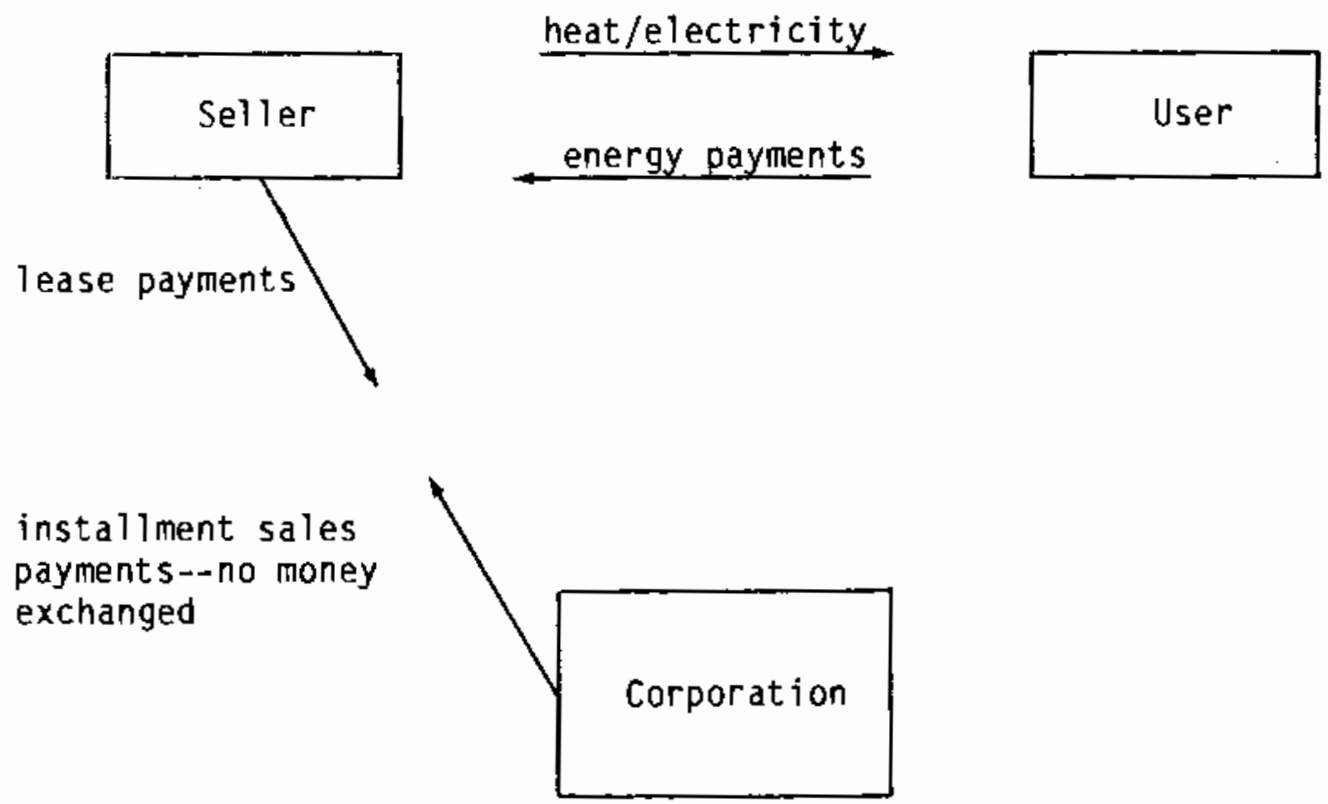

FIGURE 4.6. Sale-Leaseback ("Safe Harbor" Lease)

a user, or the utility can use the plant. Meanwhile, the corporation is able to take advantage of tax benefits, including the investment tax credit, the energy tax credit, and depreciation. When the term of the lease is up, the manufacturer or utility may choose to repurchase the property for as little as 1 dollar. 
This type of package provides advantages to both the seller and the corporation. The net cost of the property to the seller has been reduced by the amount that the corporation paid the seller for the tax benefit. The corporation has received a tax writeoff because the lease payments are equal to the debt payments, and because it may ultimately sell the depreciated property back to the original seller for less than the fair market value, realizing no capital gain. Furthermore, the corporation has invested a relatively small amount of money at-risk, and it eventually recovers this sum. The original seller has accepted most of the risk in the investment.

\subsection{JOINT VENTURE FINANCING}

The joint venture financing option offers the benefits of combining the skills and experience of different organizations through cooperative agreements. The range of possible partners in joint venture financing is virtually limitless; however, some likely participants include municipal or investorowned utilities, leasing corporations, banks, equity firms, individual investors, engineering firms, energy management companies, equipment manufacturers, equipment vendors, local government entities, nonprofit organizations, and private nonprofit foundations. Financing mechanisms that may not be possible with traditional arrangements may be developed effectively if the resources and expertise of two or more entities are used. The various parties involved may facilitate creative combinations of financing methods. These arrangements may include techniques such as issuance of bonds, raising capital from private investors, lease financing, and direct purchase. Because of the originality of many joint venture agreements, it is particularly crucial that all parties involved understand and accept their responsibilities.

\subsection{RESEARCH AND OEVELOPMENT PARTNERSHIPS}

A research and development partnership (sometimes called a research syndicate) is one package for financing industrial development. In such a partnership, a general partner (an on-going business or an inventor) will seek limited partners to obtain the funds necessary for R\&O on a particular product, such as a solar thermal plant. Limited partnerships will be sold at amounts of $\$ 5000$ 
and up. Each limited partner gets the ability to deduct all of the expenses of the partnership (because all qualified R\&D expenditures are deductible as current expense) and a chance at a proportional share of the returns if the $R \& D$ is successful.

Many R\&D partnerships will spend all of the partnership money within the first 1,2 , or 3 years, so that the deduction is relatively immediate. The attraction for the investor is relatively immediate deductions from taxable income, plus an opportunity for long-term gain. The attraction for the general partner is to obtain a kind of equity financing that individual investors find atractive without many of the constraints involved in incorporation and the sale of stock.

An issue raised by the Economic Recovery Tax Act (ERTA) is the application of the research and development tax credit to such organizations. According to. the analyses previewed to date, Congress was somewhat unfavorable toward such research partnerships and thus limited the applicability of the research and development tax credit in various ways. The definition of R\&D that applies when considering deductions is liberal. It requires the research expenditure to be paid or incurred "in connection with" the taxpayer's trade or business. [Internal Revenue Code Sec. 1974(a)(1)]. However, the definition of R\&D for purposes of a tax credit is more restrictive. Such a research expenditure must be paid or incurred "in carrying on any trade or business" [Internal Revenue Code Sec. 44F(b) (1) and $162(a)]$. This wording implies that credits for expenditures related to financing arrangements would not be allowed (Black and Boyd 1981). Furthermore, according to a House Committee report (U.S. Congress, House 1981), it appears that Congress did not intend to allow the tax credit to R\&D partnerships when agreements have been made to transfer a successful research product to the general partner or to some non-partner. The House report states, "Under the trade or business test of new section $44 \mathrm{~F}$, the credit generally is not available with regard to the taxpayer's expenditures for 'outside' or contract research intended to be transferred by the taxpayer to another in return for license or rayalty payments." This is discussed in Patterson (1981).

In any case, R\&D partnerships are a mechanism that solar thermal developers might use for particular kinds of development. A possible limited R\&D 
partnership arrangement for solar thermal financing is shown in Figure 4.7 . The inventor or manufacturer, acting as a general partner, seeks limited partners to contribute funds for research and development. The limited partners form a partnership with the inventor as general partner and, having contributed funds to the development of the idea, receive an immediate tax deduction for R\&D expenses [Internal Revenue Code Sec. 44F]. The inventor/general partner uses the funds, along with knowledge and labor, to develop and manufacture the facility. The R\&D partnership attempts to license the idea and sell the facility to a user of heat and electricity. If the product of the research and development is successfully licensed or sold, the limited partners receive a share of the royalties or the purchase price.

\subsection{INDUSTRIAL REVENUE BONDS}

Industrial revenue bonds are tax-exempt bonds issued by local governmental entities. The purpose of the federal government industrial revenue bond program is to provide a tool to local governments for use in encouraging industrial development within their jurisdictions. The bonds are exempt from

knowledge

and labor

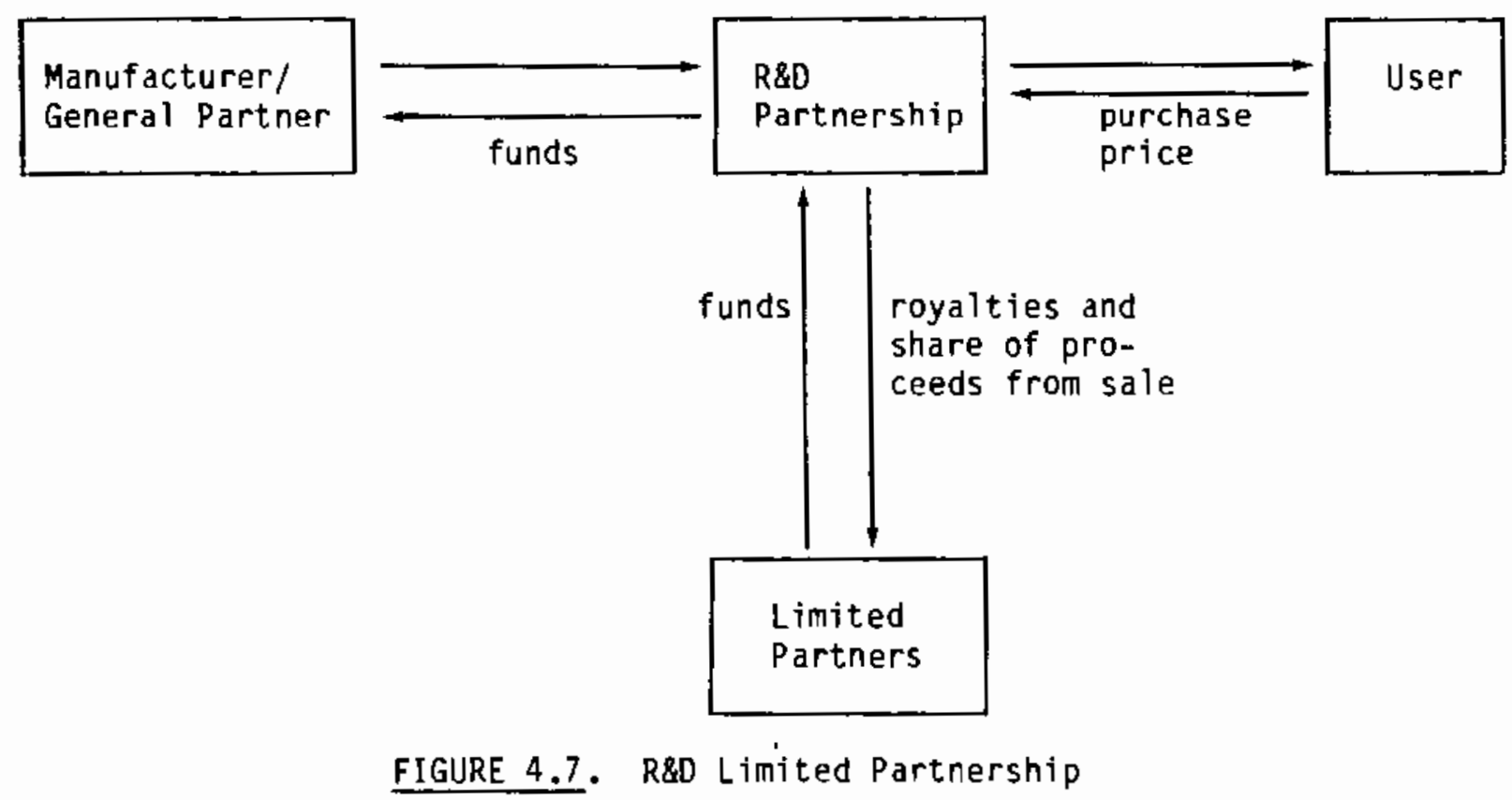


federal income taxation because a local government entity issues them. However, the term "revenue" in the title indicates that the repayment of principal and interest on the bonds is guaranteed solely by the proceeds of an industrial project financed by the bonds.

Industrial revenue bonds are especially significant for energy projects such as solar thermal technologies because certain restrictions are placed on the total size of the issue ( $\$ 10 \mathrm{million}$ ) and on subsequent investments within the jurisdiction for a period of 5 years unless the facility qualifies as an exempt facility. Facilities for furnishing electricity are one category of exempt facilities allowed in the federal legislation. State implementing legislation varies from state to state; however, energy facilities are usually included in the exempt category. Thus, if an industrial revenue bond program is available in the particular jurisdiction in which a solar thermal plant is to be located, this type of financing can be considered.

As shown in figure 4.8 , the local governmental jurisdiction issues the bond, which is either sold in a public offering or placed privately with investors. The investors pay the face amount of the bond and over a period of years

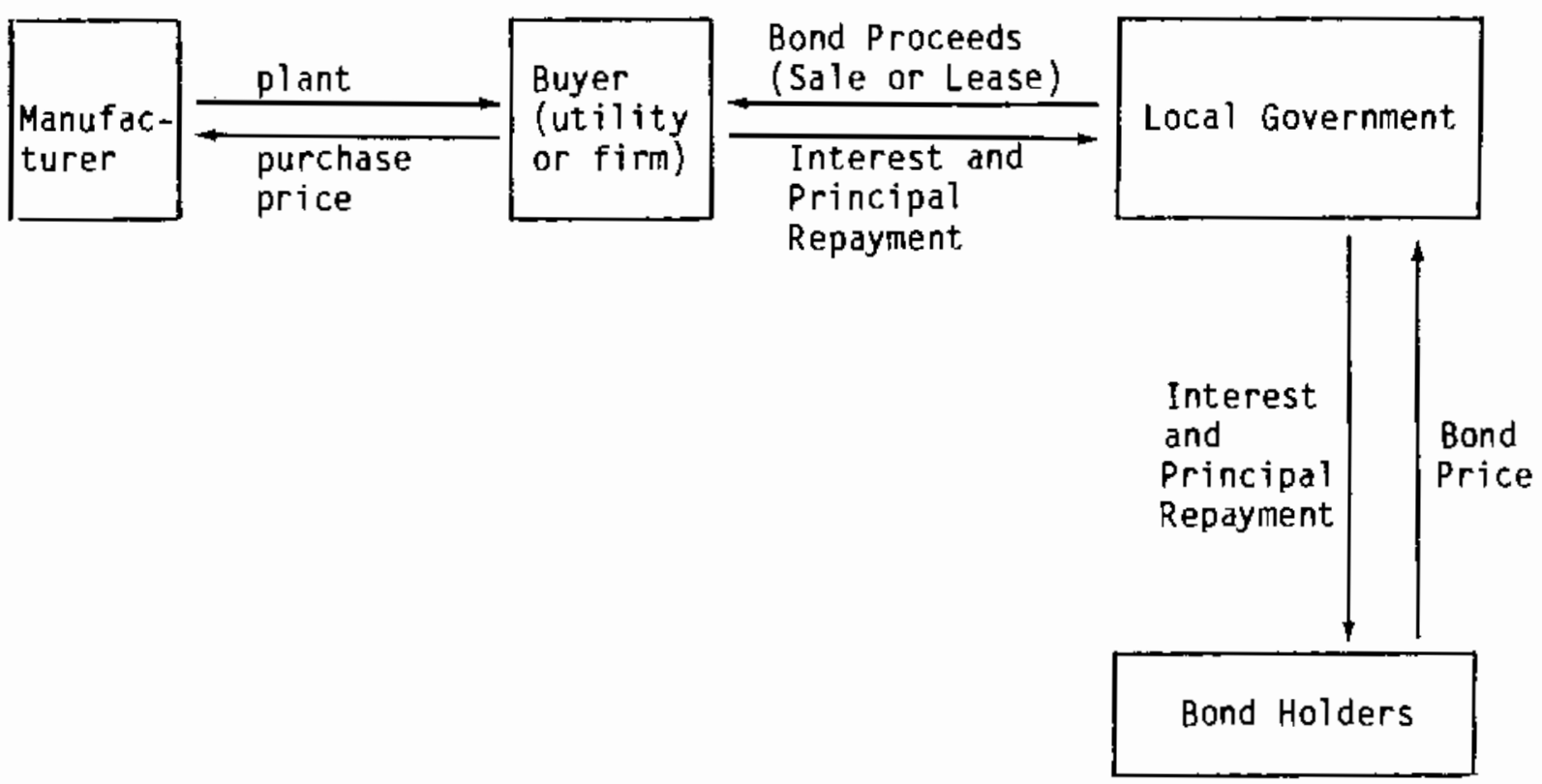

FIGURE 4.8 Industrial Revenue Bonds 
receive interest and principal payments. The governmental entity then turns over the proceeds of the bond sale, less expenses for issuing the bond, to the industrial concern which uses the proceeds to construct a plant or to buy equipment. The relationship between the local government entity and the industrial firm may take the form of a lease or sale arrangement. In either case, the industrial concern assumes an obligation to pay back to the local government entity amounts of money sufficient to cover the principal repayment and interest on the bonds, which is then turned over to the bond holder. A trust may be set up to handle the bond repayments; thus, the governmental entity does not need to set up an organization to manage this process. Once the bond is approved, the government entity has no active role in the transaction.

The costs of using this form of financing depend on whether a public offering is anticipated, or whether the bonds will be placed privately with one or more investors. In the latter case, the financing costs are lower. In most situations, the financing costs are taken out of the proceeds from the bond sale, and the industrial firm gets the remainder.

The interest rate on industrial revenue bonds varies from 200 to 500 basis points below rates on taxable corporate securities of comparable risk. For example, the interest rate on industrial revenue bonds is currently $13 \%$, compared with the typical $16 \%$ rate on normal bonds. The difference results in a savings of 300 basis points. The lower interest rate results from the federal tax exemption on the bond interest, which is realized by the bond holder. Depending on market conditions, the variation between the interest rates on taxable and tax exempt issues has changed over time. Thus, the attraction of industrial revenue bonds to a solar thermal project is a substantial savings in financing costs compared with a taxable debt issue.

One cautionary note should be made about the use of bonds. Because a federal tax exemption is involved for the bond holder, "double-dipping" provisions prevent use of the full energy tax credit for a facility that is financed with industrial revenue bonds. The portion of the project financed with industrial revenue bonds is not eligible for the energy tax credit. The value of the lower financing cost must be compared to the value of the tax credit in assessing this option for a particular project. It should also be 
noted that under recent tax law changes, depreciation "shall be determined using the straight-line method (with a half-year convention and without regard to salvage value)," (Tax Equity and Fiscal Responsibility Act of 1982). This change in the law is not included in the example (Chapter 7) of financing a solar thermal plant using industrial revenue bonds, but is provided here as a point of information. Federal laws pertaining to industrial revenue bonds have changed often in recent years, and state laws vary widely. 
.

, 


\subsection{EVALUATION OF ALTERNATIVE FINANCING PACKAGES}

This chapter describes several techniques available for evaluating participation in alternative solar thermal financial arrangements. The merits and limitations of each are discussed. The actual methodology used to evaluate the hypothetical case studies is presented in Chapter 6.0 .

Before the evaluation techniques are described, a few basic financial concepts are defined to ensure that all readers have at least some understanding of financial analysis.

\subsection{BASIC FINANCIAL CONCEPTS}

If an investor is to evaluate his participation in an alternative financing arrangement, he must be familiar with concepts such as the time value of money, discount rate, current and constant dollars, nominal and real interest rates, and tax credits. Proper understanding of these concepts is essential to reach a correct decision regarding a potential investment. Those readers who are familiar with these concepts may wish to skip this section and proceed to the description of our modeling equations.

\subsubsection{Time Value of Money}

People prefer consuming goods today to postponing their consumption unti? a future date. This gives rise to the concept that money has a time value associated with it. If a person (lender) lends $\$ 100$ today to another person (borrower), the lender must forego $\$ 100$ dollars worth of consumption until a later date. The lender is willing to enter this type of arrangement only if he expects to be reimbursed for postponing this consumption. The premium paid by the borrower to the lender is called interest. Interest is paid per period of time, typically on an annual or quarterly basis.

For example, if an investor deposits $\$ 100$ into a savings account paying $10 \%$ annually at the beginning of the year, the investor will have $\$ 110$ in that account at the end of the year. If the $\$ 110$ is left in the account for a second year, he will be paid $10 \%$ interest and $\$ 121$ will be in his account at the end of the second year. This procedure of allowing interest to accumulate is called compounding. 
In general, the future value of an investment can be found by

$$
F=P(1+i)^{t}
$$

where $F=$ future value of the investment

$P=$ present value of the investment, or principal

$i=$ rate of interest per time period

$t=$ number of time periods.

If the investor is interested in knowing the amount of money he would have to invest today to have "F" dollars in the future (called the present value of the investment), he would solve for $P$ in Equation 5.1. That is,

$$
P=F\left(\frac{1}{(1+i)^{t}}\right)
$$

The term $\frac{1}{(1+i)^{t}}$ is referred to as the discounting factor. This factor is one of the key elements of the net present value methodology (discussed in Section $5.2 .1)$.

\subsubsection{Nominal and Real Interest Rates}

Interest rates are specified as either nominal or real interest rates. Nominal interest rates are what banks quote and are used by most people who typically deal in financial transactions. Real interest rates are merely nominal interest rates that have been adjusted for inflation.

To convert a nominal interest rate into a real interest rate, the nominal rate is discounted by the inflation rate. That is,

$$
\frac{(1+i)}{(1+p)}=(1+r)
$$

where $i=$ nominal rate of interest

$p=$ inflation rate

$r=$ real interest rate

For example, the real rate of interest that the investor will receive by placing his money in a savings account paying a nominal rate of interest of $10 \%$ per year, assuming a $6 \%$ inflation rate is 


$$
\frac{(1+0.10}{(1+0.06)}=(1+0.0377)
$$

or about $4 \%$.

Evaluating one's participation in an investment opportunity can be performed using either nominal or real interest rates. However, two important rules to remember when using either type of interest rate are:

1. If real interest rates are chosen, all interest rates used throughout the analysis must be specified in real terms. The same is true if nominal rates áre chosen.

2. If real interest rates are used, all other monetary inputs, expenses, revenues, escalation rates, etc., must be adjusted for inflation. The procedure for converting other monetary inputs into inflation-adjusted units is discussed in the next section.

\subsubsection{Current and Constant Dollars}

Current and constant dollars are analogous to nominal and real interest rates. Constant dollars are current dollars that have been adjusted for inflation. Current dollar values are the actual amount of money that will be spent or received in a given year. The conversion from current to constant dollars is achieved by dividing the current dollar amount by $1+$ the inflation rate, or

$$
\text { Constant dollars }=\frac{\text { Current dollars }}{(1+p)^{t}}
$$

where $p=$ inflation rate per period

$t=$ number of periods.

For example, 100 current 1983 dollars is converted to constant 1981 dollars (assuming a $6 \%$ annual inflation rate) by

$$
\text { Constant } 1981 \text { dollars }=\frac{\$ 100}{(1+0.06)^{2}}=\$ 89
$$

This conversion tells us that $\$ 89$ in 1981 has the same purchasing power as $\$ 100$ has in 1983 , assuming a $6 \%$ annual inflation rate. 
Either constant or current dollars can be used when evaluating alternative financing arrangements. Government projects are typically evaluated using constant dollars and real interest rates. However, most private investment decisions are made using current dollar values and nominal interest rates. The reason for this preference is that private businesses must calculate their annual federal and state income tax liabilities, which involve calculating capital depreciation. Capital depreciation is calculated on a current dollar basis.

Again, the rule to remember is that constant dollars are used with real interest rates and that current dollars are used with nominal rates.

\subsubsection{Tax Liability}

Taxes have an enormous impact on most all investments. They often are a key difference separating profitable from unprofitable ventures.

Taxes are based on accounting income, which is different from cash flow, and the distinction between these two concepts needs to be understood. The net cash flow from a project, for any period, is simply the cash inflows minus the cash outflows; all cash flows are included regardless of how or why they occur. These project cash flows should include inflows such as equity cash investments, proceeds from lenders, project revenues, revenue from the sale or lease of project assets, and revenue from the sale of tax credits under the Economic Recovery Tax Act of 1981. All cash outflows during the period that arise due to the project must be subtracted from the inflows to arrive at the net cash flow for the period. Typical cash outflows include capital expenditures, interest and principal payments, operating and maintenance costs, lease payments, and project income taxes.

For many investment projects, cash outflows exceed cash inflows during the construction years and perhaps the first few years of operation. Figure 5.1 presents the hypothetical annual cash flows of a project. Along the $x$ axis are years of the project life, running from 0 to 10 . The $y$ axis measures the value of the cash flows as indicated by arrows. Arrows above the line indicate years with positive cash flows and those below the line indicate years of negative cash flows. 


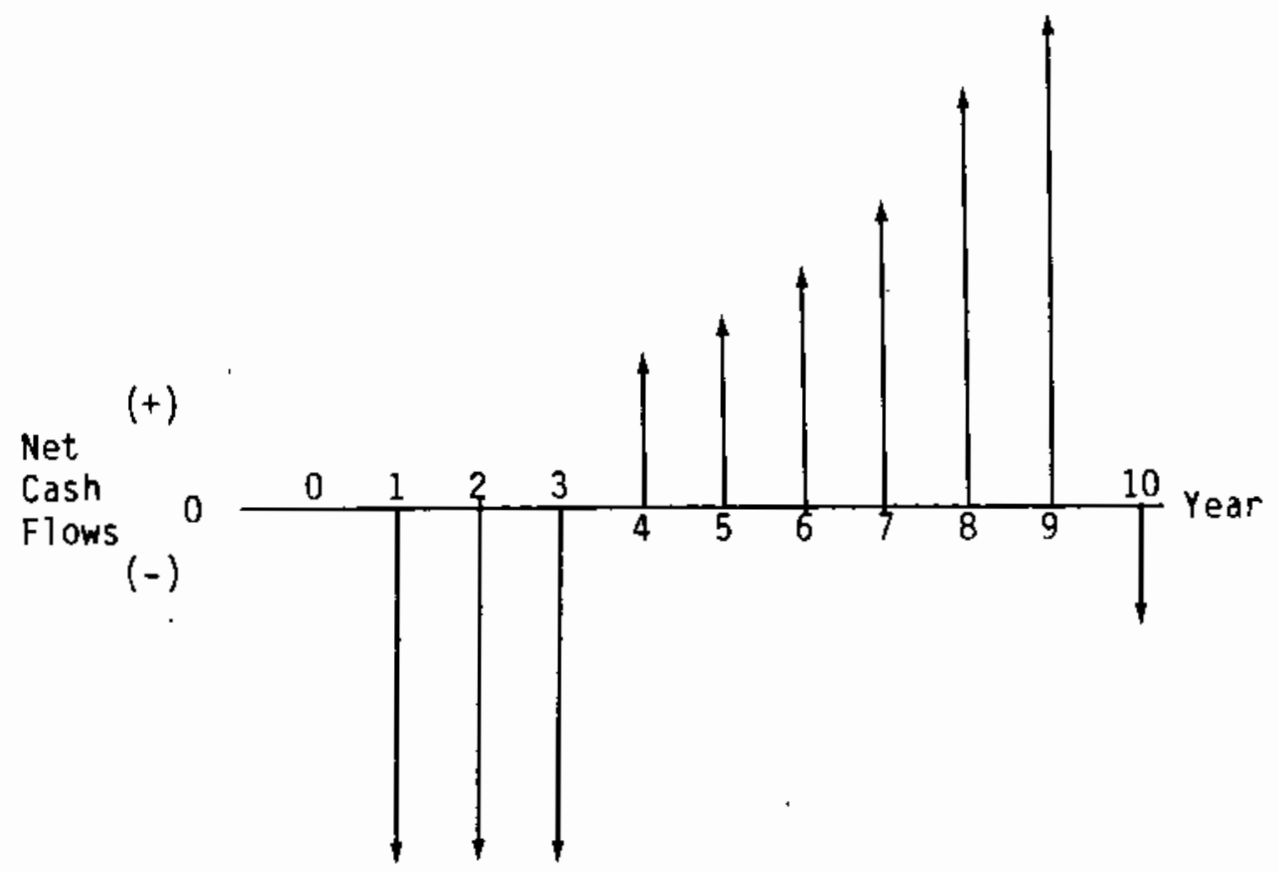

FIGURE 5.1. Annual Cash Flows

Years 1,2 , and 3 are construction years with large negative cash flows. In year 4, the project begins operation and continues to operate through year 9. In year 10 , the project operating 1 ife has ended and the facility must be dismantled, resulting in a slightly negative cash flow. The concept of cash flows is important in calculating the net present value of a project.

Accounting income is an equally important financial concept; it is used in calculating the tax liabilities of a project. Accounting income is revenue less expenses and depreciation. Expenses are those cash outflows listed above, excluding the repayment of principal and capital expenditures. That is,

$$
A I=R-E-D
$$

where $A I=$ accounting income

$R=$ revenue

$E$ = expense

$D=$ depreciation

Depreciation is the method of expensing capital expenditures on long-lived assets. The Economic Recovery Tax Act of 1981 makes it possible to claim depreciation under the Accelerated Cost Recovery System (ACRS). For property with a 
5-year tax 1 ife (most solar equipment) that is placed in service between 1981 and 1984 , the first year's depreciation expense is $15 \%$ of the original asset cost. In the second year the depreciation is $22 \%$ of the original cost, and in the third through fifth years, $21 \%$ of the cost, for total of $100 \%$. For property placed in service after 1984, the depreciation schedule is first year, $18 \%$; second year, $33 \%$; third year, $25 \%$; fourth year, $16 \%$; and fifth year $6 \%$.

The two principal types of taxes are income taxes (federal and, in some instances, state) and property taxes. State income and property taxes are paid first, and are deductible from federal income tax liabilities.

A project's state tax liability is found by multiplying the accounting income before taxes by the state tax rate and then subtracting any state tax credits. That is,

$$
S L=(A I-P T) S-S T C+P T
$$

where $S L=$ state tax liability

$$
\begin{aligned}
\mathrm{AI} & =\text { accounting income } \\
\mathrm{s} & =\text { state income tax rate } \\
\mathrm{STC} & =\text { state tax credits } \\
\mathrm{PT} & =\text { state and local property taxes }
\end{aligned}
$$

State and local property taxes are based upon the assessed value of the property. Some states give solar energy equipment an exemption from property taxes.

The federal tax liability calculation also starts with accounting income before taxes, but the state tax liability is deducted before multiplying by the federal tax rate and then subtracting any federal tax credits. The sum of these liabilities is the total project income tax liability.

$$
F T L=(A I-S L) f-F T C
$$

where $F T L=$ Federal tax liability

$f=$ Federal tax rate

FTC = Federal tax credits

It should be noted that accounting income is used in calculating a project's tax liability, and is not the same as cash flow which is used to calculate a project's net present value. 


\section{1 .5 Tax Credits}

Tax credits are allowances that are subtracted directly from an investor's tax liability. The two major categories of tax credits are federal investment tax credits and federal and, in some instances, state solar energy tax credits.

The current federal investment tax credit allows the investor to subtract $10 \%$ of the original capital cost of an investment directly from his federal tax liability. Of course, only certain items qualify as investments and it is strongly recommended that an investor seek assistance from a tax consultant or the IRS when determining those items that qualify.

The current federal solar energy tax credit allows $15 \%$ of the original capital cost of a solar investment to be subtracted from the federal income tax liability. As an example of a state energy tax credit, California allows $25 \%$ of the original capital cost of solar equipment to be subtracted from state income tax liabilities. Again, assistance from a tax consultant or the IRS is reconmended when deciding which investments qualify for these tax credits.

In addition to the tax credits, depreciation of capital investment allows a decrease in income tax liabilities. Under current tax laws, there is a depreciation allowance of $15 \%$ in the first year of a project's operation if that project is placed in service between 1981 and 1984 . The value of this depreciation allowance is that it shields income from taxation. The value of the tax shield is calculated as

$$
I S=\operatorname{MTR}(D)
$$

where IS = income shield

$M T R=$ marginal state or federal tax rate

$D=$ depreciation

Thus, the depreciation allowance can help reduce both state and federal income tax obligations.

Table 5.1 illustrates the net effect of both the tax credits and depreciation for the first year that the solar equipment is placed in service, using the State of California as an example of state tax effects. For large investments the corresponding reduction in tax liabilities may also be large, in 
TABLE 5.1. Percentage Deductible from First Year Tax Liability

\begin{tabular}{|c|c|c|c|c|}
\hline $\begin{array}{c}\text { Maximum Margina } \\
\text { Tax Rate }(\%) \\
\end{array}$ & $\begin{array}{l}\text { First Year } \\
\text { Depreciation } \\
1985(\%) \\
\end{array}$ & $\begin{array}{c}\text { Tax Credits } \\
\text { Investment/Energy } \\
\text { (\% of Tota) } \\
\text { Investment) } \\
\end{array}$ & First & $\begin{array}{r}\text { Year } D \\
(\%) \\
\end{array}$ \\
\hline \multicolumn{5}{|l|}{ Personal } \\
\hline $\begin{array}{ll}\text { California } & 11 \\
\text { Federal } & 50 \\
\text { Total } & \end{array}$ & $\begin{array}{l}18 \\
18\end{array}$ & $10^{25}+15$ & & $\begin{array}{l}26.98 \\
\frac{20.51}{47.49}\end{array}$ \\
\hline
\end{tabular}

Corporate

$\begin{array}{llccc}\text { California } & 9.6 & 18 & 25 & 26.73 \\ \text { Federat } & 46 & 18 & 10+15 & 20.98 \\ \text { Total } & & & & 47.71\end{array}$

fact, the tax credits may exceed the amount of the tax liability. Under current tax laws, the excess credits on federal taxes may be carried forward to of fset tax Tiabilities in future years to a maximum of 15 years (Economic Recovery Tax Act of 1981). However, because of the time value of money, it is advantageous to take the deduction as soon as possible. The deduction (in present value terms) is not worth as much next year as it is this year.

\subsection{POSSIBLE EVALUATION METHODOLOGIES}

Several methodologies are available for evaluating the economic feasibility of solar thermal projects and alternative financing methods. This section provides a brief description of the more common or useful methodologies, including net present value, profitability index, internal rate of return, and payback period.

\subsubsection{Net Present Value}

The net present value (NPV) of an investment is the sum of all of the discounted net cash flows, or

$$
N P V=\sum_{t=1}^{n} \frac{N_{t}}{(1+d)^{t}}
$$


where NPV = net present value

$$
\begin{aligned}
N C F_{t} & =\text { net cash flow in the " } t^{\text {th" }} \text { year } \\
d & =\text { discount rate } \\
t & =\text { year of the net cash flow }
\end{aligned}
$$

A decision to invest in a project is made when the NPV is positive. If more than one independent $(a)$ project is being considered and the risk and capital investments are comparable, the project with the largest NPV should generally be selected. When investment capital is limited, a variation of the NPV method known as the profitability index (see Section 5.2.2) may help in choosing among alternative projects.with positive NPV.

In using this evaluation methodology, one must be careful to properly consider cash flows. For example, depreciation is not in itself a cash flow; however, it does reduce one's tax liability by an amount equal to the marginal tax rate multiplied by the depreciation, and this is a cash flow. Also, the use of the NPV method requires the selection of a discount rate.

The appropriate discount rate to use in NPV calculations is often called the cost of capital. This is the rate at which the firm can procure funds through borrowing or equity sales, so long as these funds can be used profitably and are employed in projects of risk similar to the present line of business.

The discount rate is the minimum rate of return that an investor is willing to accept from an investment. A project that yields a negative NPV is a project that provides a rate of return less than this minimum acceptable level. Any project with a negative NPV will be rejected by the investor since he can use these funds in some other investment opportunity and receive at least the return specified by the discount rate. Likewise, those projects with positive NPV provide a rate of return greater than the minimum acceptable level, and will be pursued.

To determine the appropriate discount rate for an individual project, the opportunity cost of capital must be determined. The opportunity cost is the

(a) Independent in the sense that the outcome of one project does not affect the outcome of another. 
return available on the next best investment of equivalent risk. If the cash flows over the life of the project occur with certainty, then they are riskfree. An appropriate risk-free discount rate, equal to the time value of money, might be the rate applicable to a U.S. Government Bond of the same duration as the project.

However, if the cash flows are uncertain, then a risk premium must be added to the risk-free rate. The amount of this premiun varies directly with the amount of risk or uncertainty. For example, a relatively low-risk venture should have a discount rate slightly above the risk-free rate, such as the return on respected corporate bonds. A high-risk investment with uncertain cash flows should generally be assessed with a large discount rate. This rate should be the same that is applied to other investments of similar risk in the financial markets.

Problems can occur if a project has large negative net cash flows late in its 1 ife, and too high a discount rate is used. An example of this cash flow stream is illustrated in Figure 5.2 .

Discounting cash flow streams places higher weight on near term cash flows than on later cash flows since near term cash flows are valued more by the investor (due to the time value of money). Using an excessively high discount rate will tend to place a smaller weight on the negative cash flows occurring

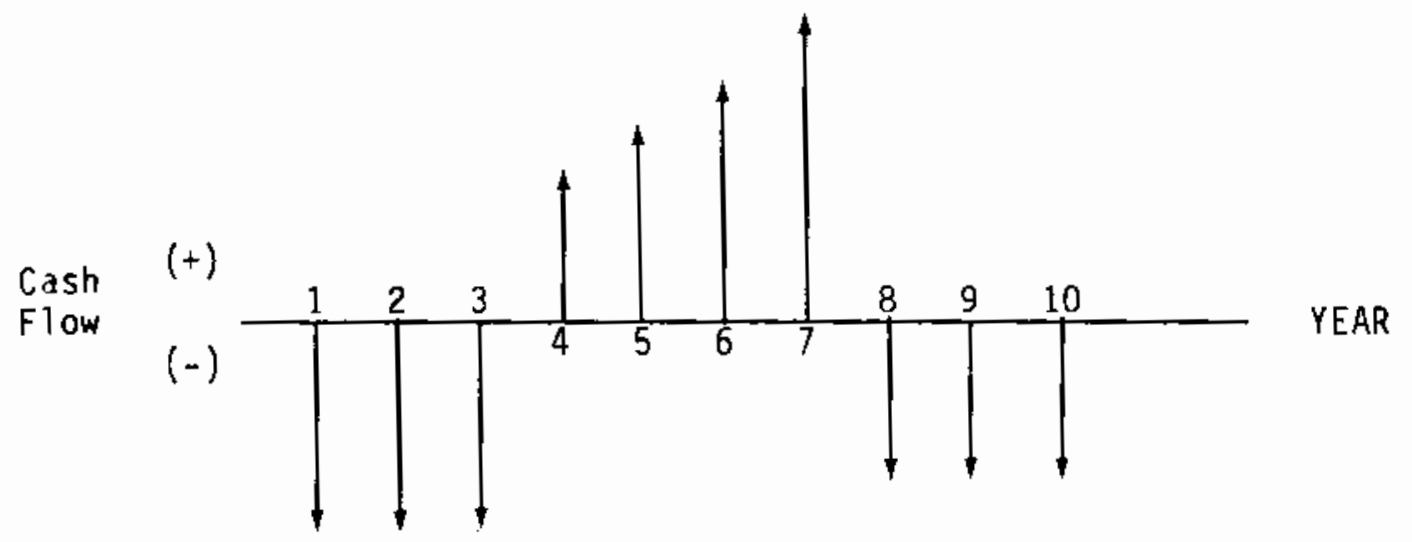

FIGURE 5.2 Large Negative Cash Flows Late in Project Life 
in years 8-10 and a relatively greater weight on the positive cash flows occurring in year 4-7. This will tend to bias the NPV results positively.

The selection of the appropriate discount rate is often not easy or exact. Thus, when using the NPV methodology, it is recommended that a sensitivity analysis be performed using several discount rates.

\subsubsection{Profitability Index}

In a case where a company has unlimited funds, all projects with a positive NPV would be accepted. The profitability index (PI) is a modification of the NPV methodology and is used to account for the more typical case in which investment funds are limited and additional funds cannot be secured from external sources. The profitability index methodology will help the investor choose among competing projects with different initial capital investments. The profitability index of a project is the ratio of the net present value(a) divided by the initial capital investment, or

$$
P I=\frac{N P V_{i}}{I_{i}}
$$

where $P I=$ profitability index

$N P V_{j}=$ net present value of the "ith" project

$I_{i}=$ initial capital investment of the "ith" project

Projects are then ranked by their profitability index from highest to lowest. Funds are allocated to those projects with the highest profitability indices until the funds are exhausted.

There are two drawbacks to the profitability index method. First, when selecting the projects near the budget limit, one must remember that the profitability index is merely a contrivance from maximizing the net present value subject to a budget constraint. Sometimes, when close to the budget limit, strict adherence to the rule of selecting the project with the greatest profitability index does not maximize the NPV for the current amount able to be invested. Also, this method works only when one resource is rationed and only over one period.

(a) Only those projects with positive NPV are considered. 


\subsubsection{Internal Rate of Return}

The internal rate of return (IRR) of a project is defined as the discount rate for which a project's present value of the after tax cash flows is zero. Stated alternatively, it is the rate of interest that equates the project's negative and positive net cash flows. In equation form,

$$
\sum_{t=1}^{n} \frac{\text { NegCF }}{(1+I R R)^{t}} \sum_{t=1}^{n}=\frac{\text { PosCF }}{(1+I R R)^{t}}
$$

where NegCF = negative cash flows

DosCF = positive cash flows

IRR = internal rate of return.

As stated earlier, for many projects, cash outflows in the first few years typically exceed cash inflows, particularly in the case of projects with long construction times. Once a project begins operation, cash inflows begin to grow to the point where they exceed outflows and positive net cash flows are attained.

Discounting can be viewed as a systematic process of weighting annual cash flows. Since an investor places a relatively greater value on near-term than future cash flows, discounting places relatively greater weight on near-term cash flows. The actual weight is determined by the discount rate used.

Increasing the discount rate will place greater weight on near-term cash flows and, for typical projects, tends to cause the NPV to be negative. Very small discount rates will place relatively more weight on future cash flows and tend to cause the NPV to be positive. By varying the discount rate of a project, it is possible to generate a list of corresponding NPV, ranging from positive to negative (Table 5.2). The discount rate at which the NPV equals zero is the IRR for that project. For the hypothetical cash flows presented in Table 5.2, the relationship between the discount rate and present value is presented in Table 5.3. In this example, the IRR is $10 \%$.

Once the IRR is calculated for a project, it is compared to the opportunity cost of capital. If the IRR is greater, the investment should be accepted 
TABLE 5.2. Hypothetical Cash Flows

$\begin{array}{cc}\text { Year } & \text { Net Cash Flow }(\$) \\ 0 & -1000 \\ 1 & 100 \\ 2 & 100 \\ 3 & 1100\end{array}$

TABLE 5.3. Discount Rate Versus Present Value of a Project

$\begin{array}{rr}\text { Discount Rate }(\$) & \text { Present Value (\$) } \\ 5 & 129.62 \\ 10 & 0.00 \\ 15 & -99.29\end{array}$

since it provides a return greater than the minimum acceptable rate of return for projects with equivalent risk.

The IRR methodology has several drawbacks. First, for some cash flow streams there is no discount rate that will make the NPV equal to zero; i.e., the IRR is undefined in some cases. For some cash flow streams, more than one discount rate will result in the NPV equaling zero; i.e., the IRR is not unique. In general, there can be as many IRRs as there are changes in the signs of cash flows.

When choosing between two mutually exclusive investment alternatives, selecting the project with the largest IRR will not ensure wealth maximization if any one of the following conditions is true:

- the projects require different initial investments

- the projects have different lives

- the cash flow streams of the projects are significantly different

- current investment alternatives affect future investment opportunities.

If any of the above conditions applies, proper evaluation of two projects requires that the IRR method be applied to the incremental cash flows. For 
example, if an investor is deciding between projects $A$ and $B$ (that meet the above conditions), the annual cash flow streams of the two projects are subtracted. That is,

$$
\mathrm{CF}_{\mathrm{Ai}}-\mathrm{CF}_{\mathrm{Bi}}
$$

where $\mathrm{CF}_{\mathrm{Ai}}=$ cash flow of Project $A$ in ith year $C F_{B i}=$ cash flow of Project $B$ in ith year.

An IRR is then calculated for the resulting cash flow stream. If the IRR is greater than the minimum acceptable level, Project $A$ is more desirable than $B$; if the IRR is below the minimum acceptable level, the converse is true. The incremental IRR indicates only which project is preferred. It does not state if the individual project IRR is above the minimum acceptable level: that must be calculated separately. Notwithstanding these problems, the IRR, when used correctly and with its limitations in mind, will give wealth-maximizing answers. A study of large, stable businesses revealed that about two-thirds used IRR by itself or in combination with other methods (Schall 1978). The IRR method is conceptually more complex than NPV. Also, any problem that can be analyzed using IRR can also be done with NPV; the converse, however, is not true. For these reasons and the ones stated before, the NPV method has been selected as the analysis methodology to be used in this guidebook.

\subsubsection{Payback Period}

The length of time it takes to recover the initial investment in a project is called the payback period. For example, if $\$ 100$ is invested and pays a return of $\$ 25$ a year, the payback period is 4 years $(\$ 100 / \$ 25)$. Similarly, if that same investment paid $\$ 30$ per year, then the payback period would be $31 / 3$ years. Shorter payback periods are preferred to longer ones, and projects are accepted only if payback occurs before a specific time limit set by management. This decision rule works well only if all cash outflows occur at the beginning of a project, and all subsequent cash inflows are constant for all time. Few projects fall into this narrow framework.

The payback period is a theoretically inappropriate technique for maximizing profit or return on investment. It has three major drawbacks. First, there is no consideration of any cash inflows or outflows after the payback 
period. Second, the method gives equal weight to all cash flows, ignoring the timing of returns within the payback period. As shown before, a dollar received today is worth more than a dollar to be received next year; thus this method does not consider the time value of money. Finally, the decision of where to put the cutoff point is arbitrary, and no optimal cutoff point exists. In spite of these problems, the payback method is still widely employed in industry, because of its simplicity. However, it is very rarely used by itself as a decision rule, and is usually applied in conjunction with one of the other evaluation methods described earlier. 



\subsection{COMPUTER MODELING EQUATIONS FOR EVALUATING ALTERNATIVE FINANCING ARRANGEMEMTS}

This chapter describes the development of a financial framework and modeling equations for use with a personal computer. This framework could also be used by those who do not have access to a microcomputer to manually evaluate the economic attractiveness of various financial arrangements. The modeling equations were developed specifically for application with computer spreadsheet packages associated with personal computers. Computer spreadsheets are excellent for sensitivity type analyses. Given changes in the assumed input values, such a program can rapidly recalculate all of the various cash flows and compute the new effective net present value. If the reader has access to a personal computer and appropriate software, net present value calculations can be performed quickly. Computer spreadsheets are discussed in more detail in Appendix B, where they are applied to the modeling equations developed in this chapter.

The basis for developing this financial evaluation model is the net present value methodology (described in Chapter 5.0). This framework was selected for several reasons.

- NPV allows the development of a generalized model that can be used to assess any solar thermal technology and a number of different financing arrangements

- NPV technique is familiar to most potential investors

- NPV takes into account the concept of the time value of money

- NPV minimizes the problems associated with other evaluation procedures such as multiple solutions, and equal weighting of cash flows

- NPV can be applied to all possible participants in an alternative financing arrangement.

\subsection{USER AND TECHNOLOGY SPECIFIC PARAMETERS}

Since the economic resources available to the various investors in an alternative financing arrangement could be significantly different and since the size and costs of the solar thermal options under consideration could be 
numerous, several user and technology specific inputs are required for model operation. All inputs are specified in current (i.e., noninflation adjusted) dollars.

- capital costs of the solar thermal facility - This variable is entered in two forms: 1) total costs of solar capital, nonsolar capital, and land, and 2) capital investment for specific individuat years. The purpose for the distinction between types of capital in the model is that solar and nonsolar capital investments are eligible for different tax credits and depreciation schedules, and land is a nondepreciable asset. The year-by-year capital investments must also be identified since the construction times of solar thermal plants vary, and this information is needed for discounting purpose.

- debt fraction -. If a portion or all of the project is financed through borrowing, the percentage financed must be specified to calculate loan payments.

- loan life and loan interest rate - All interest rates must be specified in nominal terms.

- lease payments - All lease payments are specific to the contract between the lessee and the lessor.

- operating and maintenance costs, and escalation rate - These costs are entered in current dollars for the first year of operation and automatically escalated by the 0\&M escalation rate.

- tax rates - State and federal income and property tax rates will be specific to the participant, and to the state in which the plant is located.

- solar and investment tax credits - Most participants will receive federal investment and solar tax credits. The amount of the state tax credits is state-specific. Investors should check the Internal Revenue code to find out the extent to which they qualify for these tax credits. 
- depreciation schedules - Separate depreciation schedules are used for solar and nonsolar capital equipment.

- energy sold from plant - This is specified in kilowatt-hours per year.

- energy displaced and escalation rate - If the energy generated is consumed by the owner rather than being sold, the value of energy displaced is included in the model.

- energy sales price - This variable is entered in nominal dollars for year 0 .

- energy revenue escalation rate - The annual sales price of energy is escalated by this nominal escalation rate.

\subsection{MODEL FINANCIAL EQUATIONS AND METHODOLOGY}

The following financial equations are used in calculating the outputs of the alternative financing model. Cash flows are assumed to occur at the end of the year and are discounted to the beginning of the year. Also, year 0 is assumed to be January 1 of the year in which the first expenditure occurs, and is the base year for discounting. However, if a project is financed through a loan, it is assumed that the loan income is received at the beginning of year 0 , and the first loan payment is not due until the end of that year.

In this model, costs are defined as a cash payment and they are not necessarily related to expenses for income tax purposes or to costs that are accrued in financial accounting.

\subsubsection{Total Costs}

Annual total costs are defined as the sum of capital, operating and maintenance costs, and loan and lease payments. $0 r$,

$$
C_{t}=\text { CAP }_{t}+0 \& M_{t}+\text { LOANPAY } t+\text { LEASE PAY } t
$$

\subsubsection{Operating and Maintenance Costs}

Annual 0\&M costs are defined as the O\&M costs in the base year multiplied by the $0 \& M$ escalation rate. Or,

$$
O \& M_{t}=(0 \& M \text { costs in year " } 0 ")(1+0 \& M \text { escalation })^{t}
$$




\subsubsection{Loan Payment}

Annual loan payment is defined as total capital investment multiplied by the debt fraction multiplied by the loan payment factor. Or,

$$
\text { Loan Payment }=\text { TCI (DF) } i / 1-(1+i)^{-t}
$$

where $T C I=$ total capital investment

$$
\begin{aligned}
D F & =\text { debt fraction } \\
\mathbf{i} & =\text { loan nominal interest rate } \\
t & =\text { loan repayment period. }
\end{aligned}
$$

\subsubsection{Loan Interest Payment}

Annual loan interest payments are defined as the remaining loan balance multiplied by the loan interest rate. Or,

$$
\text { Loan Interest Payment } t=\left(\text { loan }_{t} \text { balance }_{t-1}\right)(i)
$$

\section{2 .5 State Taxes}

Annual state tax payments are the sum of the property taxes and state income taxes. State income tax is based on the project's taxable income and is reduced by the value of the state solar credits. In some states, property taxes can be deducted from state taxable income.

That is,

State Tax Payment ${ }_{t}={\text { Property } \text { Taxes }_{t}+\text { [Energy Revenue }}_{t}-$ O\&M

$$
\begin{aligned}
& \text { Costs }_{t} \text { - Loan Interest } t_{t} \text { - Depreciation } \text { L }_{\text {- }} \\
& \text { Lease Payment } t_{t} \text { - Property } \text { Taxes }_{t} \text { ] (State Tax } \\
& \text { Rate) - State Tax Credit } \text { t }_{\text {}}
\end{aligned}
$$

\subsubsection{Federal Income Tax}

Annual state tax payments are subtracted from taxable income to derive federal taxable income. Federal solar and investment tax credits directly reduce a project's income tax liability. That is,

\footnotetext{
Federal Tax Payment $t=\left[\right.$ Energy Revenue $_{t}-0 \& M$ Cost $_{t}-$ Loan Interest $_{t}$ - Depreciation - Lease Payment $_{t}$ State Tax Payment $t_{t}$ (Federal Tax Rate) Federal Tax Creditst
} 


\subsubsection{Total Tax Liability}

Total annual tax liability is the sum of the project's state and federal tax liabilities.

Total Tax Liability $y_{t}=$ State Tax Liability L Federal Tax Liability $_{t}$

\subsubsection{Energy Revenue}

The principal revenue source from participating in an alternative financing arrangement will be from the sale of energy to a utility, or from the direct sale to the customers. The procedure used to calculate the revenue received from these sales is the quantity of energy sold per year, multiplied by the energy sales price in year 0 multiplied by the energy escalation rate. Or,

Energy Revenue $t=($ Wh of Energy Sold $t)$ (Energy Sale Price in year " $0 "$ )

$$
(1+\text { Energy Escalation Rate })^{\mathrm{t}}
$$

If all or a portion of the energy generated is not sold, but used by the plant operators to displace energy typically purchased, the value of this displaced energy is treated as energy revenue. This revenue stream is calculated as:

$$
\begin{aligned}
\text { Energy Revenue }_{t}= & \text { (kWh of Energy 0isplaced } \left.\text { R }_{\mathrm{t}}\right)(\text { Value of the Energy } \\
& \text { Displaced in year "0")(1+Energy Displaced } \\
& \text { Escalation Rate })^{t} .
\end{aligned}
$$

\subsubsection{Effective Net Cash Flow}

The annual effective net cash flow is the revenue received from the sale of the energy less costs and tax payments. Or,

Effective Net Cash Flow = Energy Revenue E $_{t}$ - Capital Expenditures $t$ -

$$
\begin{aligned}
& \text { 0\&M Costs } \text { Coan Payment }_{t} \text { - Lease } \\
& \text { Payments }_{t} \text { - State Taxes } t \text { - Federal Taxes } t \\
& + \text { Cash Inflows from Loans Received in Year } 0
\end{aligned}
$$

This cash flow is termed an "effective" net cash flow since it is assumed in this model that any financial losses incurred will be used to shield income from other sources. This assumption is reflected in the treatment of negative 
income tax liabilities. If tax liabilities are negative for a specific project, no income tax would be paid. However, in this model, if the tax payment (after accounting for tax credits) is negative, this value is used in the above equation to calculate the "effective" net cash flow. This assumption could be relaxed to allow carryover of tax benefits (particularly tax credits) to future years, rather than assuming they shield income from other sources in the year they occur.

\subsubsection{Effective Present Value}

The effective present values are derived by dividing each annual effective net cash flow by the appropriate discounting factor; that is,

$$
\text { Effective Present Value }=\sum_{t=1}^{n} \frac{\text { Effective Cash Flow }}{(1+i)^{t}}
$$

\subsection{MODEL RESULTS}

The output of the model includes the following information for specific participants on a year-by-year basis.

- Pre-tax cash flows, subdivided into:

- Energy revenue

- Capital investment

- Loan and lease payments

- Tax liabilities

- Effective net cash flow

- Effective net present value.

Only projects with positive effective present values will be pursued by investors. Projects with negative effective present values will be rejected since they provide a return less than the minimum acceptable level. That is, project funds would be used in alternative investment opportunities expected to receive a minimum acceptable return equal to the discount rate.

The model described in this section was developed to provide the investor with a financial framework for making a preliminary assessment of his participation in alternative financing arrangements. Before comitting investment 
funds, the investor should perform a more detailed assessment of the various alternatives using one or more of the evaluation methodologies described in Chapter 5.0. Although the model framework described above would be useful for a detailed project model framework evaluation, a more detailed projection of cash flows would be desirable for final investment decisions. 



\subsection{PROJECT EVALUATION EXAMPLES}

This chapter will illustrate the evaluation of several alternative financing packages for developing solar thermal facilities. The evaluations that fotlow are at a level of detail appropriate for screening purposes. If one or more options show potential merit after a preliminary investigation of this kind, a more detailed examination would be warranted. Only after such a detailed examination should a final investment decision be made.

Five of the financing packages described in chapter 4.0 were chosen for this case study analysis. Selection of the financing packages for the case studies was somewhat arbitrary. The five selected were chosen to demonstrate the various allocations of responsibilities and cash flows possible under alternative financial arrangements. The net present value evaluative methodology employed in the analysis was described in Chapter 5.0. Mathematical analysis of the cash flows associated with each case study was completed with the aid of the modeling equations described in Chapter 6.0. The year-by-year cash flows for the principal actors in each case are discussed later in this chapter. Further discussion of the effect of changes in key parameters on cash flows and net present value is presented in Chapter 8.0 .

The case studies represent a range of different financing/ownership possibilities and are meant to primarily serve illustrative purposes. By no means should the five particular financial arrangements chosen be considered better or worse than other possibilities. The intent of this chapter is to illustrate the economic evaluation of prospective financial packages, not to create a ranking of these packages. Even among the five financial packages considered in the case studies, a relative ranking is neither justified nor necessary, since the relative attractiveness of the packages could change for different investors or economic assumptions. Each of the case studies requires inputs for plant capital and operating and maintenance (0\&M) costs, electric power or process heat costs, and various financial and tax parameters. This analysis does not purport to provide the definitive figures for either solar thermal power plant costs, the worth of electric power or process heat, or the appropriate tax and financial rates. Rather, the figures employed in the case 
studies are intended to represent reasonable estimates and assumptions of what these parameters should actually be.

Each of the five financing packages was combined with a solar thermal technology to create a case study. In all of the cases, the solar collector is the parabolic trough. The solar thermal equipment is integrated into either a process heat plant (three cases) or an electric power plant (two cases). The five cases, their actors, and associated plant type are identified in Table 7.1. A

\section{TABLE 7.1 Case Studies}

\section{(1) Sale with Borrowed Financing}

User/Owner: Private Industrial Corporation

Manufacturer/Solar Plant Builder

Lending Institution

20 MWt Process Heat; Energy used by Industrial Corporation

(2) Third-Party Lease

User: Investor Owned Utility

Owner: Private Investor Corporation

Manufacturer/Solar Plant Builder

10 MWe Electric Power; Energy sold by Utility

(3) Leveraged Lease

User: Investor Owned Utility

Owner: Private Investor Corporation

Lending Institution

Manufacturer/Solar Plant Builder

10 MWe Electric Power; Energy sold by Utility

(4) Sale - Leaseback

Seller/User: Private Industrial Corporation

Owner: Private Investor Corporation

Manufacturer/Solar Plant Builder

20 Mwt Process Heat; Energy used by Industrial Corporation

(5) Industrial Revenue Bonds

Owner/User: Private Industrial Corporation

Lender: Municipality

Manufacturer/Solar Plant Builder

20 MWt Process Heat; Energy used by Industrial Corporation 
thorough description of the actors, the exchange of cash for goods and services, the tax implications associated with each of the five financing packages was given in Chapter 4.0 .

\subsection{CASE STUDY INPUT PARAMETERS}

In this section the selection of input parameters for the case studies will be discussed. Plant construction and annual 0\&M costs, the value of electric power and process heat, various tax rates, and discount rates for each of the owners and users are among some of the more important parameters. This section is not meant to provide justification for a particular value for any of the parameters. Rather, the discussions are intended to provide background as to how and why the input parameters were selected.

\subsubsection{Plant Parameters}

Numerous types of solar collectors could be integrated into a plant for producing process heat or electricity. Parabolic troughs are just one choice of these many possibilities. Parabolic troughs do have some advantages over other collectors for near-term applications. Trough systems have compared favorably with other collector systems in terms of both cost and performance. Parabolic troughs can produce working fluid temperatures adequate for electric power as well as process heat production. Troughs are also currently available from several manufacturers. Heliostat/central receiver (powertower) systems have shown promise, especially for electric power production, but the availability of heliostats is currently on a special-order basis only. Although trough systems may have advantages in the near future and were chosen for these case studies, this should by no means preclude consideration of another solar energy system in an alternative financing arrangement.

Plant size selections were chosen based on marketable output and reasonable size. A 10-MWe electric power plant is small by utility standards, but is a reasonable size that could certainly be built. A 10-Mwe heliostat/ central receiver plant has al ready been built; a 10-MWe parabolic trough plant would seem to be a reasonable extension of currently constructed facilities. A 20-MWt process heat plant is larger than most solar thermal installations to date, but most of these systems do not meet a large percentage of 
plant thermal needs. A plant size of 20-Mwt is within a short extension of current construction experience and also within the size range of many industrial load requi rements.

Solar thermal power plant design and cost information was obtained from available reports (Apley 1980; Bird 1981) and contact with solar thermal equipment manufacturers. Cost information from these and other sources was integrated to produce capital and 0\&M cost estimates for both 10-MWe and 20-MWt parabolic trough plants. Plant cost and annual output was based on a 0.40 capacity factor. Capital and $0 \& M$ costs are presented in Table 7.2 for both electric power and process heat plants, along with their associated annual power output. A 10-MWe parabolic trough plant is about twice the size and cost of a 20-MWt plant. However, as noted in Table 7.2, the land charge for the process heat plant is more than that for the electric power plant. The logic is as follows: process heat plants would be located adjacent to the industrial facility using the thermal energy. Land near industrialized areas will likely command a much higher price than land suitable for an electric power plant site. Although the process heat plant is about half the physical size of the electric power plant, total land costs are higher because of much higher costs per acre.

\subsubsection{Economic Parameters}

Inflation, taxes, and the cost of capital must be considered in any economic evaluation involving a choice between two or more alternatives. The

\section{TABLE 7.2 Plant Capital and O\&M Costs}

\begin{tabular}{lcc} 
Total Cost & $\begin{array}{c}\text { Electric Power } \\
\text { Costs, M\$ }\end{array}$ & $\begin{array}{c}\text { Process Heat } \\
\text { Costs, M\$ }\end{array}$ \\
\cline { 2 - 2 } Solar Part & 54.4 & 25.4 \\
Land & 52.6 & 24.6 \\
Structures & 1.1 & 1.3 \\
0\&M & 0.7 & 0.5
\end{tabular}

Annual Output $35.04 \times 10^{6} \mathrm{kWeh} \quad 70.08 \times 10^{6} \mathrm{kWth}$ 
inflation rate is one of the key assumptions since so many other parameters inherently include an inflation factor. In this analysis an inflation rate of 6\% served as the baseline for determining many of the other economic parameters. If another inflation rate were assumed, many of the following economic parameters would change correspondingly. Associated with a $6 \%$ inflation rate are capital, 08M, and energy escalation rates of 6,7 , and $8 \%$, respectively. Baseline capital and 0\&M costs were given in Table 7.2. Baseline energy costs of $\$ 0.030 / \mathrm{kWth}$ and $\$ 0.085 / \mathrm{kWh}$ are based roughty on the cost of producing thermal and electric energy from fuel oil.

State and federal income taxes and state property taxes were considered in the case study analyses. State and federal solar tax credits and the federal investment tax credit were allowed for those entities to which they apply. The tax rates employed are appropriate for the State of California. State tax rates will obviously change, depending on location. Depreciation is based on the ACRS tables for equipment placed into service in 1985. Tax rate assumptions are summarized in Table 7.3 .

Several different organizations are involved in the five case studies that were examined. Discount rates were formulated for each of the organizations that was a major party to each of the case studies. Differences in risk, sources of funds, alternative investments, and points of view account for differences in discount rate between organizations and case studies. The discount

TABLE 7.3 Tax Rates for Solar Thermal Case Studies

\begin{tabular}{lc}
\multicolumn{1}{c}{ Applicable Taxes and Credits } & Rate \\
\hline Federal income tax & $46 \%$ \\
State income tax & $9.6 \%$ \\
State property tax & $1.0 \%$ \\
Federal investment tax credit & $10 \%$ \\
State investment tax credit & $0 \%$ \\
Federal solar investment tax credit & $15 \%$ \\
State solar investment tax credit & $25 \%$
\end{tabular}


rates were formulated based on an expected inflation rate of $6 \%$ and do not necessarily represent appropriate discount rates under current (September 1982) conditions. In all cases, the discount rates are on an after-tax basis.

In general, the appropriate discount rate is the after-tax weighted cost. of capital. Investment capital is obtained from either debt (bonds) or equity (stock) sources. The weighted cost of capital depends on the relative portions of debt and equity financing (the debt/equity ratio), the cost of debt (debt rate) and the cost of equity (equity rate). The effective or after tax cost of capital accounts for the tax deductibility of the interest on debt. The after tax weighted cost of capital (ATWCC) for a $50 / 50$ debt/equity ratio, $10 \%$ debt rate, $15 \%$ equity rate and $50 \%$ tax rate would be calculated as

After Tax Weighted Cost of Capital $=0.5(0.5)(0.10)+0.5(0.15)=0.1=10 \%$ The ATWCC is the appropriate discount rate for analyzing cash flows not explicitly including the receipt and repayment of capital sources. In an ATWCC analysis, money for initial investments or other outwardly flowing cash flows is assumed to be available at the ATWCC. Future net revenue or other inwardly flowing cash flows, when discounted at the ATWCC, are implicitly accounting for the required return on borrowed funds.

For each of the owners in the five case studies, funds are borrowed (debt financing) from another party within the financing arrangement to finance a portion of the solar thermal plant. The receipt and repayment of these borrowed funds is explicitly accounted for as a positive cash flow followed by a series of negative cash flows. The debt portion of the ATHCC equation is no longer valid when the debt-related cash flows are treated in this manner. The cash flows are viewed from the owner's (equity) position and, as such, the equity cost of capital is the appropriate discount rate.

Investor-owned utilities are involved in two of the cases as plant users, but not as owners. The capital structure for the utility was assumed to be $50 \%$ bonds, $15 \%$ preferred stock and $35 \%$ common stock. Return rates of $8.5 \%$, $9 \%$ and $13.5 \%$, respectively, yield an after-tax weighted cost of capital, or discount rate, of $8.2 \%$. An industrial corporation is the plant user in the other three cases. For two of these three cases, the industrial corporation is also the 
plant owner. Both industrial and investor corporations were assumed to acquire equity at a cost of $15 \%$. The differential above the utility's equity cost reflects the lower risk and associated expected rate of return for a utility as compared to a non regulated private corporation. A discount rate of $15 \%$ was used for the cases where cash flows associated with the receipt of loans and repayment of principal and interest were explicitly accounted for. For the case where the industrial corporation is not explicitly involved in a loan, an after-tax weighted cost of capital was used, based upon a $50 / 50$ debt/equity ratio, a debt cost of $10 \%$, and an equity cost of $15 \%$. The resulting discount rate for this case is $10 \%$.

An investor corporation is assumed to be an organization that has acquired all of its capital on an equity basis at a cost of $15 \%$. Its discount rate is 15\% whether or not it is explicitly involved in a loan. Investor corporations are owners in three of the cases but lease the plants to other users. Owners, users, and their discount rates are summarized in Table 7.4.

A discounted cash flow, net present value calculation was completed for only the owner and user involved in each case study. Several other actors, namely solar thermal equipment manufacturers, general contractors, banks, investor groups, and municipalities, would also be involved in one or more of the financial packages. A satisfactory return is generated for the owner or

TABLE 7.4 Discount Rates for Case Study Organizations

\begin{tabular}{|c|c|c|c|c|}
\hline Case & Owner & $\begin{array}{l}\text { Discount } \\
\text { Rate } \\
\end{array}$ & User & $\begin{array}{c}\text { Discount } \\
\text { Rate } \\
\end{array}$ \\
\hline $\begin{array}{l}\text { Sale w/borrowed } \\
\text { financing }\end{array}$ & Industrial Corp. & $15 \%$ & Industrial Corp. & $15 \%$ \\
\hline Third-Party Lease & Investor Corp. & $15 \%$ & Utility & $8.2 \%$ \\
\hline Leveraged Lease & Investor Corp. & $15 \%$ & Utility & $8.2 \%$ \\
\hline Sale-Leaseback & Investor Corp. & $15 \%$ & Industrial Corp. & $10 \%$ \\
\hline $\begin{array}{l}\text { Industrial Revenue } \\
\text { Bonds }\end{array}$ & Industrial Corp. & $15 \%$ & Industrial Corp. & $15 \%$ \\
\hline
\end{tabular}


user if the calculated net present value is greater than zero. The manufacturers and contractors are assumed to have their economic criteria satisfied by the purchase price of the plant. Similarly, investor groups are assumed to be satisfied by the given equity rate and banks and municipalities are assumed to be satisifed by the given loan rates and lien positions.

\subsection{CASH FLOW ANALYSIS FOR PROJECT EXAMPLES}

A brief description of each project example is given in this section. The applicable cash flows and reasons for their occurrence are explained for each of the major actors mentioned above. Also discussed are the trends in the cash flow streams and items essential to profitability.

\subsubsection{Sale With Borrowed Financing}

This example involves an industrial corporation that owns and operates a solar thermal process heat plant. The process heat generated is consumed within their operations in lieu of energy they would otherwise have to purchase from an outside source. Financing for the solar thermal plant comes from a $50 \%$ equity contribution by the industrial corporation and $50 \%$ borrowed funds from a lending institution. The cost of equity to the company is $15 \%$ and the interest rate on the loan is $10 \%$. The cash flows associated with this case are shown in Table 7.5. The large initial positive cash flow represents the $50 \%$ loan from the lending institution. In the first year funds flow out as about half of the construction costs incurred. In the second year, construction is completed, and the plant is officially put in service by the end of December.

In the third year, the project starts earning revenue for the owner/ operator by supplying process heat that previously would have been generated from other sources. That cost of generation, which is now avoided, is the energy revenue. Operating and maintenance costs also begin in the third year and continue for the life of the plant. As mentioned before, these costs are assumed to increase at a rate of $7 \%$ per annum. The first loan payment is due at the end of year 1 , and it includes both interest and repayment of principal. The payment amount remains level throughout the life of the loan with full repayment occurring after fifteen years. 
TABLE 7.5. Cash Flow Analysis for Sale w/Borrowed Financing

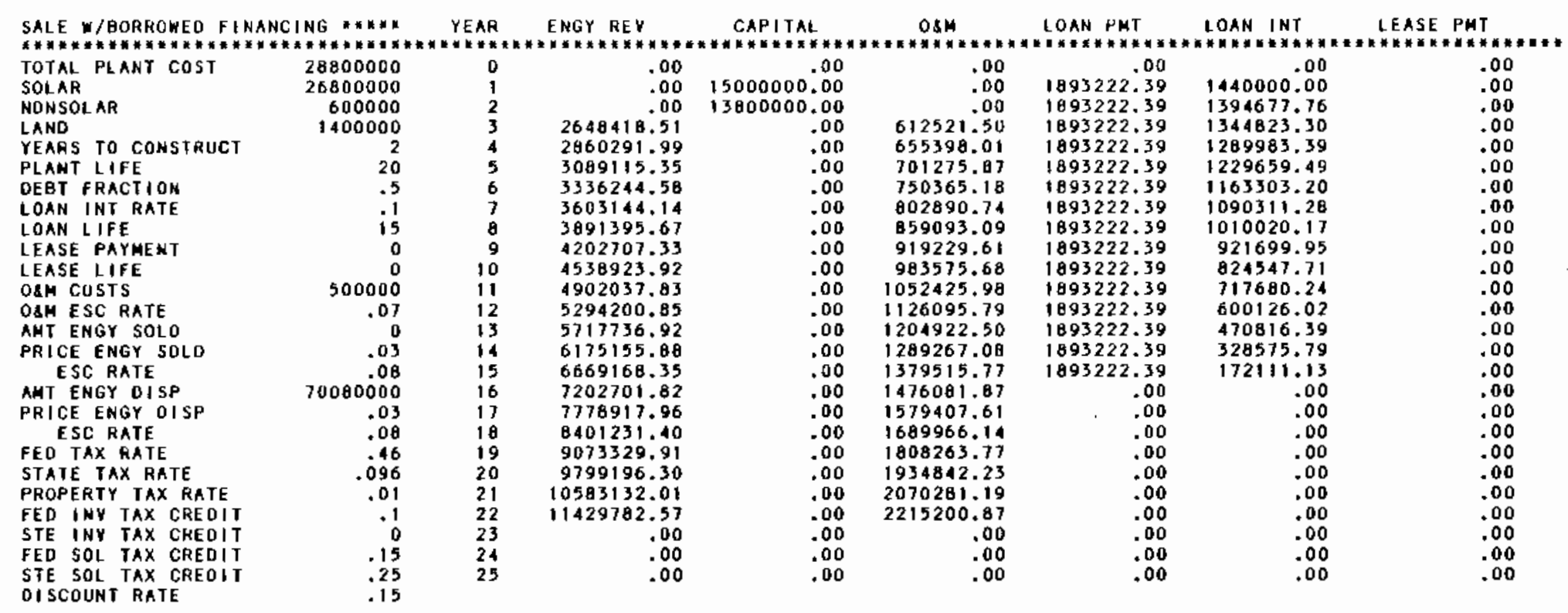

YEAR SOL OEPR(\$) N-SOL OEPR(\$) SOL OEPR(S) N-SOL DEPR(\$) STATE IAX

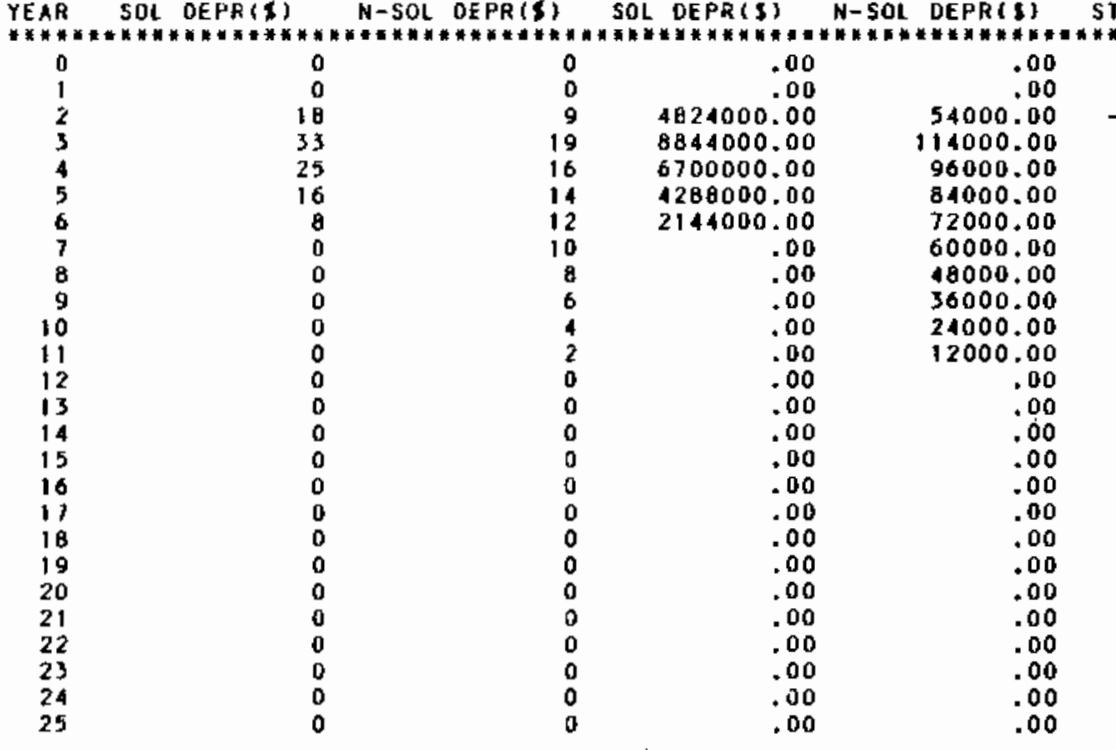

FED TRX

NET CASH FLW EFFTVE NPY

$\begin{array}{rr}.00 & .00 \\ -2640.00 & -661185.60 \\ 7041825.07 & -6406192.24 \\ -533272.92 & -3557480.55 \\ -304232.58 & -2565354.14 \\ -48174.72 & -1456196.83 \\ 184183.32 & -449699.27 \\ 418746.44 & 566350.01 \\ 449883.11 & 701223.68 \\ 483626.67 & 847389.51 \\ 520204.85 & 1005834.01 \\ 559865.43 & 1137630.44 \\ 602877.99 & 1363946.48 \\ 648383.81 & 1561062.54 \\ 697854.05 & 1775351.12 \\ 751635.98 & 2008316.52 \\ 810107.51 & 2261595.72 \\ 655504.99 & 2459242.47 \\ 904633.46 & 2671050.63 \\ 957798.35 & 2901343.18 \\ 1015329.99 & 3150551.08 \\ 1077585.68 & 3420221.96 \\ 1144951.84 & 3712029.73 \\ .00 & .00 \\ .00 & .00 \\ .00 & .00 \\ & .00\end{array}$

TOTAL EFFECTIVE NP
$-16229396.79$

$-2245205.08$

3181258.32

3181258.32
1998988.65

950172.97

$-78065.44$

$-12026.59$

59239.16

136086.99

$218 \mathrm{E} 93.59$
308058.20

410145.68

519461.24

636477.69

2885762.89

385562.89

3405924.61

3698473.00

4015043.18

4015043.18
4357600.12

.00
.00
.00

.00
14400000.00

$-1469697.85$

2783547.69

1818894.77

993850.65

414244.62

$-29347.69$

$-3931.51$

16839.47

33638.62

47049.69

57578.28

66660.14

73414.76

791.60

28371.06

253371.08

239318.38

225977.73

213321.96

201323.69

.00
.00

6625634.00 
Depreciation begins when the plant is placed in service at the end of year 2. Depreciation proceeds according to the ACRS schedules for property placed in service in 1985. Although not a cash flow, depreciation is an expense and lowers taxable income. Reported state taxes include both property and income taxes, with property tax being a deductible expense. The only federal tax considered is income tax from which all state taxes are deductible expenses. As described in Section 5.2, negative tax liabilities are considered cash inflows. Instead of carrying forward these negative obligations to offset future positive tax liabilities, it is assumed that the owner has enough income from other sources to take full advantage of the negative liability in the year it occurs.

Net cash flow is simply the difference between the cash inflows and outflows. The effective NPV is the discounted value of these cash flows. In the second year, the tax credits and initial depreciation nearly offset the large cash flow associated with the final year of construction. The next several years show declining positive cash flow as the plant is depreciated over a 5year period. Cash flows during the middle years of the project are at first negative, as the solar depreciation ends, and then turn and grow positive as the loan is paid off. This project shows a positive cash flow over an operating life of 20 years largely due to the $25 \%$ State and Federal tax credits and accelerated depreciation available.

\subsubsection{Third-Party Leasing}

In this example, an investor corporation owns a solar thermal electric power plant and leases its use to a utility. The utility operates the plant and sells the electricity to its customers. One hundred percent of the financing for the facility comes from equity provided by the investor corporation. The cost of equity for the investor corporation is $15 \%$. The cash flows associated with the third-party leasing arrangement are shown in Tables 7.6 and 7.7 for the investor corporation (owner) and utility (user), respectively. The owner of the plant has large cash outflows for construction during years 1 and 2. As before, it is assumed that the plant will be placed into service during the second year of construction. The initial depreciation and tax credits tend to offset the final year of construction cash outflows. The only revenue the owner receives from the project is the lease payments from the user. Taxes, 
IABLE 7.6. Cash Flow Analys is for Third-Party Lease-Owner

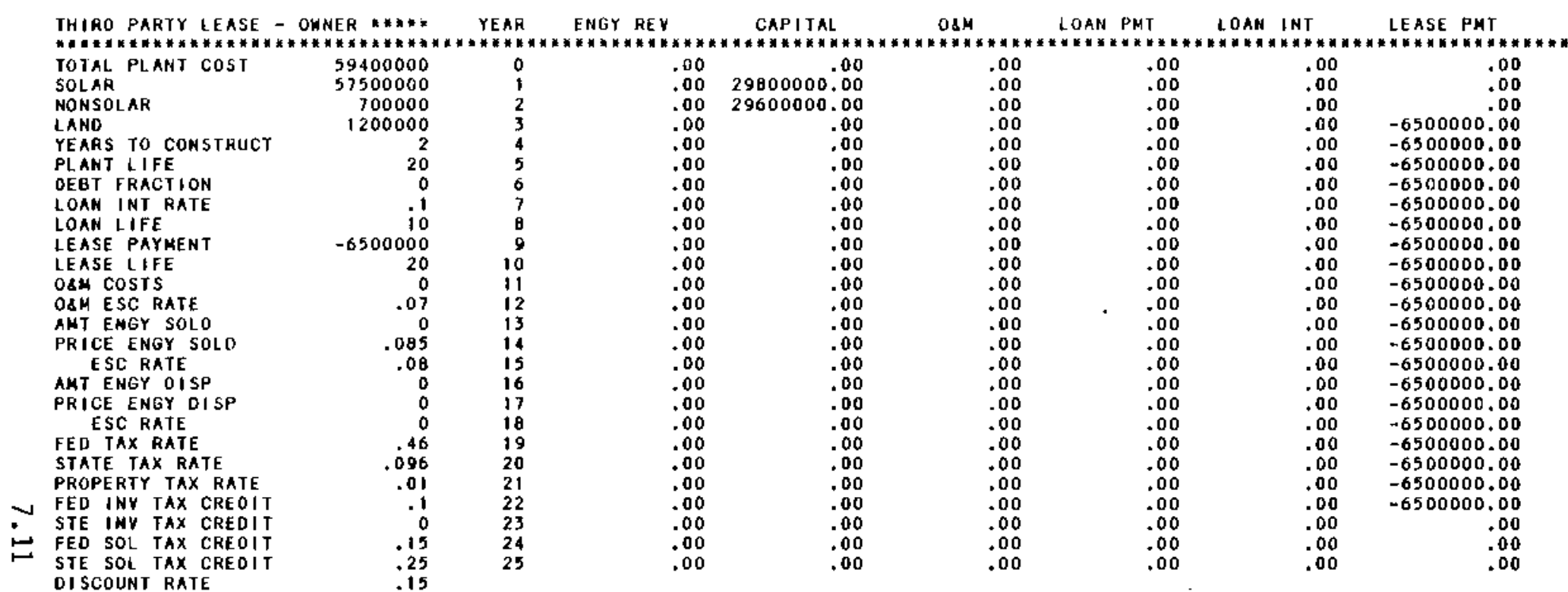

YEAR SOL DEPR(s) N-SOL DEPR(s) SOL DEPR(\$) N-SOL DEPR(\$) STATE TAX

\begin{tabular}{|c|c|c|c|}
\hline 0 & 0 & 0 & .00 \\
\hline 1 & 0 & 0 & .00 \\
\hline 2 & 18 & 9 & 10350000.00 \\
\hline 3 & 33 & 19 & 10975000.00 \\
\hline 4 & 25 & 16 & 14375000.00 \\
\hline 5 & 16 & 14 & 9200000.00 \\
\hline 6 & 8 & 13 & 4600000.00 \\
\hline 7 & 0 & 10 & .00 \\
\hline$\theta$ & 0 & $\theta$ & .00 \\
\hline 9 & 0 & 6 & .00 \\
\hline 10 & 0 & 4 & .00 \\
\hline 11 & 0 & 2 & .00 \\
\hline 12 & 0 & 0 & .00 \\
\hline 13 & 0 & 0 & .00 \\
\hline 14 & 0 & 0 & .00 \\
\hline 15 & 0 & 0 & .00 \\
\hline 16 & 0 & 0 & .00 \\
\hline 17 & 0 & 0 & .00 \\
\hline 18 & 0 & 0 & .00 \\
\hline 19 & 0 & 0 & .00 \\
\hline 20 & 0 & 0 & .00 \\
\hline 21 & 0 & 0 & .00 \\
\hline 22 & 0 & 0 & .00 \\
\hline 23 & 0 & 0 & .00 \\
\hline 24 & 0 & 0 & .00 \\
\hline 25 & 0 & 0 & .00 \\
\hline
\end{tabular}

.00
.00
63000.00
133000.00
112000.00
98000.00
91000.00
70000.00
36000.00
42000.00
28000.00
11000.00
.00
.00
.00
.00
.00
.00
.00
.00
.00
.00
.00
.00
.00
.00

269392.00
-14837672.00
-673392.00
-229776.00
268368.00
710640.00
1154256.00
1155600.00
1156944.00
1150288.00
1159632.00
1160976.00
1160976.00
1160976.00
1160976.00
1160976.00
1160976.00
1160976.00
1160976.00
1160976.00
1160976.00
1160976.00
.00
.00
.00

FED TAX

NET CASH FLW

EFFIYE NPY

$-123920.00$ $-123920.32$ $-12409650.86$ -5489919.68
-3568323.04 $-1410529.04$ -1410529.28
505245.60 2426842.24 2426842.24
2432664.00 2438485.76 2444307.52 2450129.28 2455951.04 2455951.04 2455951.04 2455951.04 2455951.04 2455951.04 2455951.04 2455951.04 2455951.04 2455951.04
2455951.04 2455951.04 00 .00 TOTAL EFFECTIVE NPY

\begin{tabular}{|c|c|}
\hline .00 & \\
\hline-29945471.68 & -26039540.59 \\
\hline-2352677.12 & -1378961.91 \\
\hline 12603311.68 & 8326332.99 \\
\hline 10298099.04 & 5887971.55 \\
\hline 7642161.28 & 3799504.80 \\
\hline 5284114.10 & $\begin{array}{l}2284468 \cdot 48 \\
1097323.29\end{array}$ \\
\hline 2918901.76 & 1097323.29 \\
\hline 2911736.00 & 951851.66 \\
\hline 2904570.24 & 825660.14 \\
\hline 2897404.48 & 716194.07 \\
\hline $\begin{array}{l}2890238.72 \\
2883072.96\end{array}$ & $\begin{array}{l}621237.22 \\
338066.95\end{array}$ \\
\hline 2803072.96 & 468579.96 \\
\hline 2883072.96 & 407460.83 \\
\hline 2883072.96 & 354313.77 \\
\hline 2883072.96 & 308098.93 \\
\hline 2883072.96 & 267912.11 \\
\hline $\begin{array}{l}2883072.96 \\
2883072.96\end{array}$ & $\begin{array}{l}232967.05 \\
202580.05\end{array}$ \\
\hline $\begin{array}{l}2883072.96 \\
2883072.96\end{array}$ & $\begin{array}{l}202380.05 \\
176156.56\end{array}$ \\
\hline 2883072.96 & 153179.62 \\
\hline 2883072.96 & 133199.67 \\
\hline & \\
\hline .00 & .00 \\
\hline .00 & .00 \\
\hline
\end{tabular}


TABLE 7.7. Cash Flow Analysis for Third-Party Lease-User

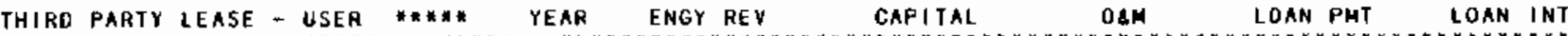

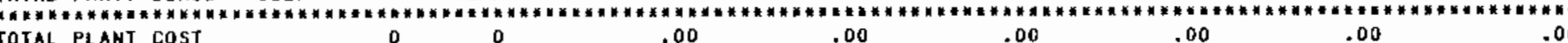
SOLAR

NONSOLAR

YEAAS TO CONSTRUCT

LEASE PAYMENT

LEASE LIFE

O\&M COSTS

O\&M ESC RATE

PRICE ENGY SOLD

ESC RATE

AHT ENGY DISP

ESC RATE

FED TAX RATE

PROPE TAX RATE

FEO INY TAX CREOIT

$\checkmark$ STE INY TAX CREOI

FED SOL TAX CREOIT

DISCOUNT RATE

0
0
0
0
2
20
0
.1
10
6500000
20
1100000
.07
3504000
.085
.08
0
0
0
.16
.096
0
.1
0
.15
.25
.082

0
1
2
3
4
5
6
7
9
9
10
11
12
13
14
15
16
17
18
19
20
21
22
23
24
25

.00
.00
.00
3751926.22
4052080.32
4376246.74
4726346.48
5104454.20
5512810.54
5953835.38
6430142.21
694453.59
7500117.88
0100127.31
0748137.49
9447988.49
10203827.57
11020133.78
11901744.48
12853804.04
13802194.76
14992770.34
16192191.97
.00
.00
.00

.00
.00
.00
.00
000
.00
.00
.00
.00
.00
.00
.00
.00
.00
.00
.00
.00
.00
.00
.00
.00
.00
.00
.00
.00
.00

.00

.00

1347547.30

1542006.90

1650803.39

1766359.62

1890004.80

2022305.13

2163866.49

2477410.75

3034934.70

3247300.12

3474696.73

3717925.51

3978180.29

4256652.91

4554618.61
4873441.92

.00

.00
.00
.00

YEAR SOL OEPR(S) H-SOL OEFR(\$) SOL DEPR(S) H-SDL OEPR(S) STATE TAX

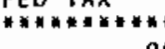

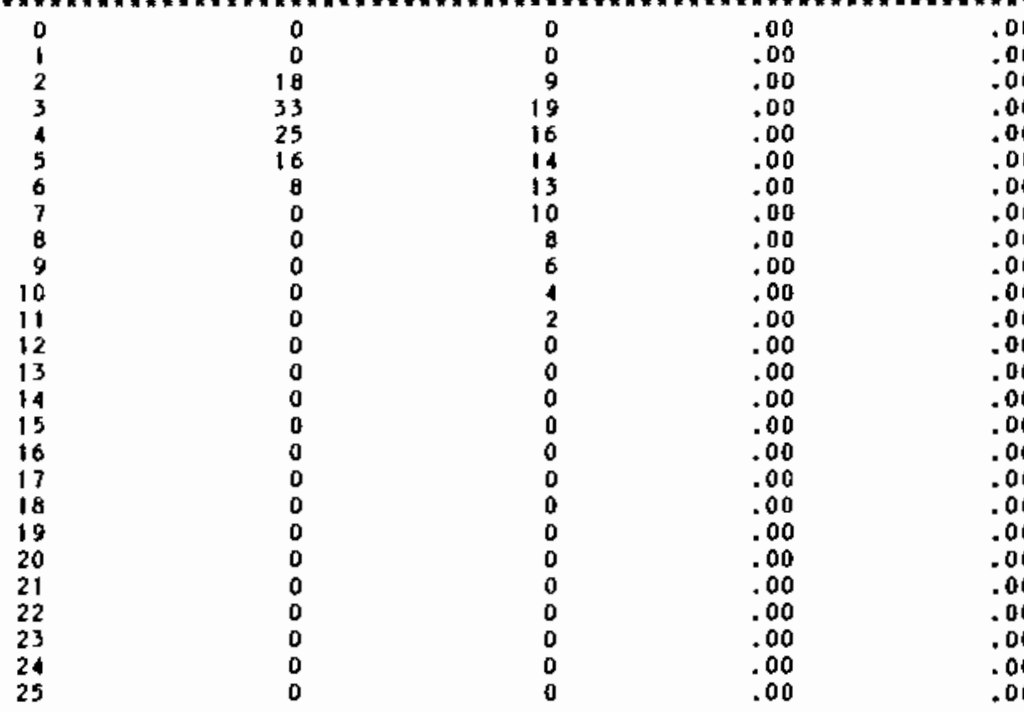

.00
.00
.00
.00
.00
.00
.00
.00
.00
.00
.00
.00
.00
.00
.00
.00
.00
.00
.00
.00
.00
.00
.00
.00
.00
.00

$\begin{array}{rr}.00 & .00 \\ .00 & .00 \\ -393179.62 & -1703123.00 \\ -373420.35 & -1617532.47 \\ -351989.78 & -1524702.38 \\ -328747.06 & -1424026.16 \\ -303542.92 & -1314846.75 \\ -276210.65 & -1196452.46 \\ -246573.10 & -1068072.46 \\ -214437.53 & -928871.90 \\ -179595.22 & -777946.63 \\ -141820.12 & -6143177.47 \\ -100867.41 & -436924.00 \\ -56472.01 & -244617.91 \\ -8346.84 & -36155.71 \\ 43810.95 & 189809.11 \\ 100361.96 & 434734.54 \\ 161646.62 & 700199.28 \\ 228067.56 & 987912.65 \\ 300052.02 & 1299725.32 \\ 378062.57 & 1637641.02 \\ 462600.01 & 2003829.02 \\ .00 & .00 \\ .00 & .00 \\ .00 & .00\end{array}$

RET CASH FL

$\begin{array}{rr}.00 & .00 \\ .00 & .00 \\ .00 & .00 \\ .00 & 6500000.00 \\ .00 & 6500000.00 \\ .00 & 6500000.00 \\ .00 & 6500000.00 \\ .00 & 6500000.00 \\ .00 & 6500000.00 \\ .00 & 6500000.00 \\ .00 & 6500000.00 \\ .00 & 6500000.00 \\ .00 & 6500000.00 \\ .00 & 6500000.00 \\ .00 & 6500000.00 \\ .00 & 6500000.00 \\ .00 & 6500000.00 \\ .00 & 6500000.00 \\ .00 & 6500000.00 \\ .00 & 6500000.00 \\ .00 & 6500000.00 \\ .00 & 6500000.00 \\ .00 & 6500000.00 \\ .00 & .00 \\ .00 & .00 \\ .00 & .00 \\ & \end{array}$

TOTAL EFFECTIYE NPY

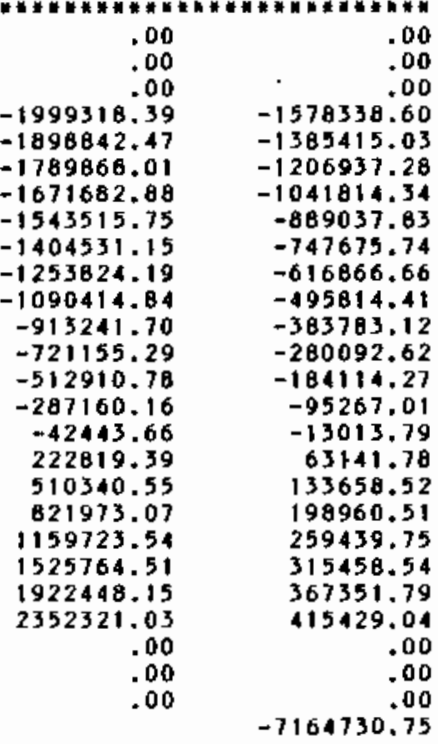


net cash flow, and effective NPV are computed here in the same manner as they were in the preceeding case. The utility (user) earns its revenue from the sale of electricity. The lease payment represents an expense in addition to operating and maintenance costs. Since the utility does not own the plant, it does not get the benefit of the depreciation tax shield; however, neither does it pay property tax on the plant. State and federal taxes, as always, are assumed to be at the maximum marginal rate; net cash flow and effective NPV are computed as before.

For the economic conditions assumed, no lease payment could result in a positive NPV for both investor and utility. Despite the large tax credits available to the owner, the $\$ 6.5$ million lease payment does not generate enough revenue to provide an adequate return. For the utility (user) the $\$ 6.5$ million lease payment overwhelms the available energy revenues for a significant portion of the plant life.

\subsubsection{Leveraged Lease}

This example is identical to the third party lease arrangement except the owner acquires $50 \%$ of the financing for the project from a lending institution. The lower cost of the borrowed money plus tax deductibility of the interest payments creates a situation where a relatively low lease payment can satisfy the economic criteria of both owner and user. Examination of the cash flows in Tables 7.8 and 7.9 shows that a $\$ 1.5$ million lease payment results in immediate positive cash generation for the utility while still allowing for a positive project NPV for the investor corporation.

\subsubsection{Sale Leaseback}

This illustration involves an industrial corporation that originally purchases/builds a solar thermal process heat plant. The industrial corporation then sells the plant to an investor corporation partially on credit. The investor corporation gives the industrial corporation a down payment on the plant, and then pays off the remaining balance over a period of years. These loan payments are matched dollar for dollar by lease payments that the industrial corporation pays to the investor corporation for the use of the plant. No money actually changes hands after the initial down payment, except for a 
TABLE 7.8. Cash Flow Analysis for Leveraged Lease-0wner

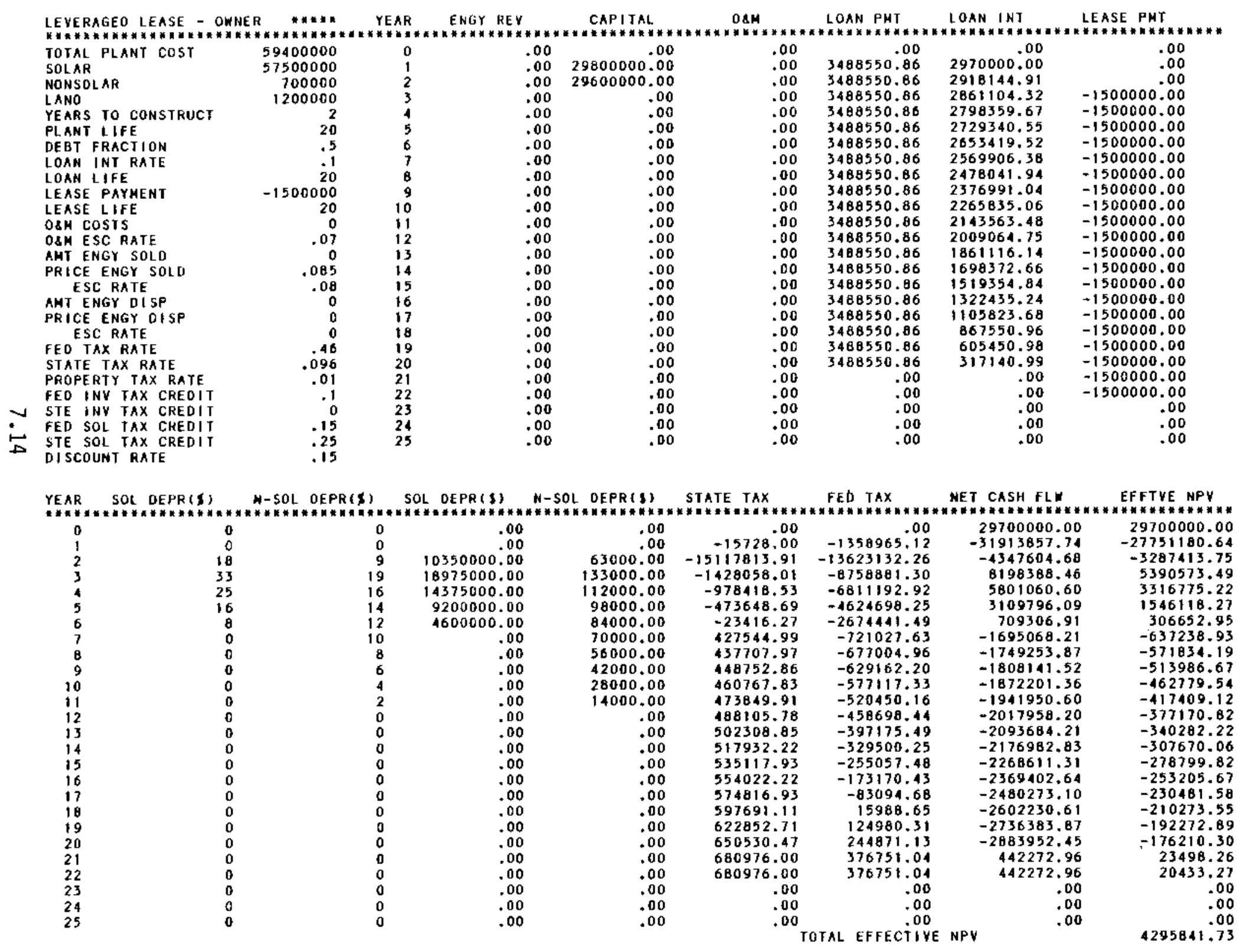


TABLE 7.9. Cash Flow Analysis for Leveraged Lease-User

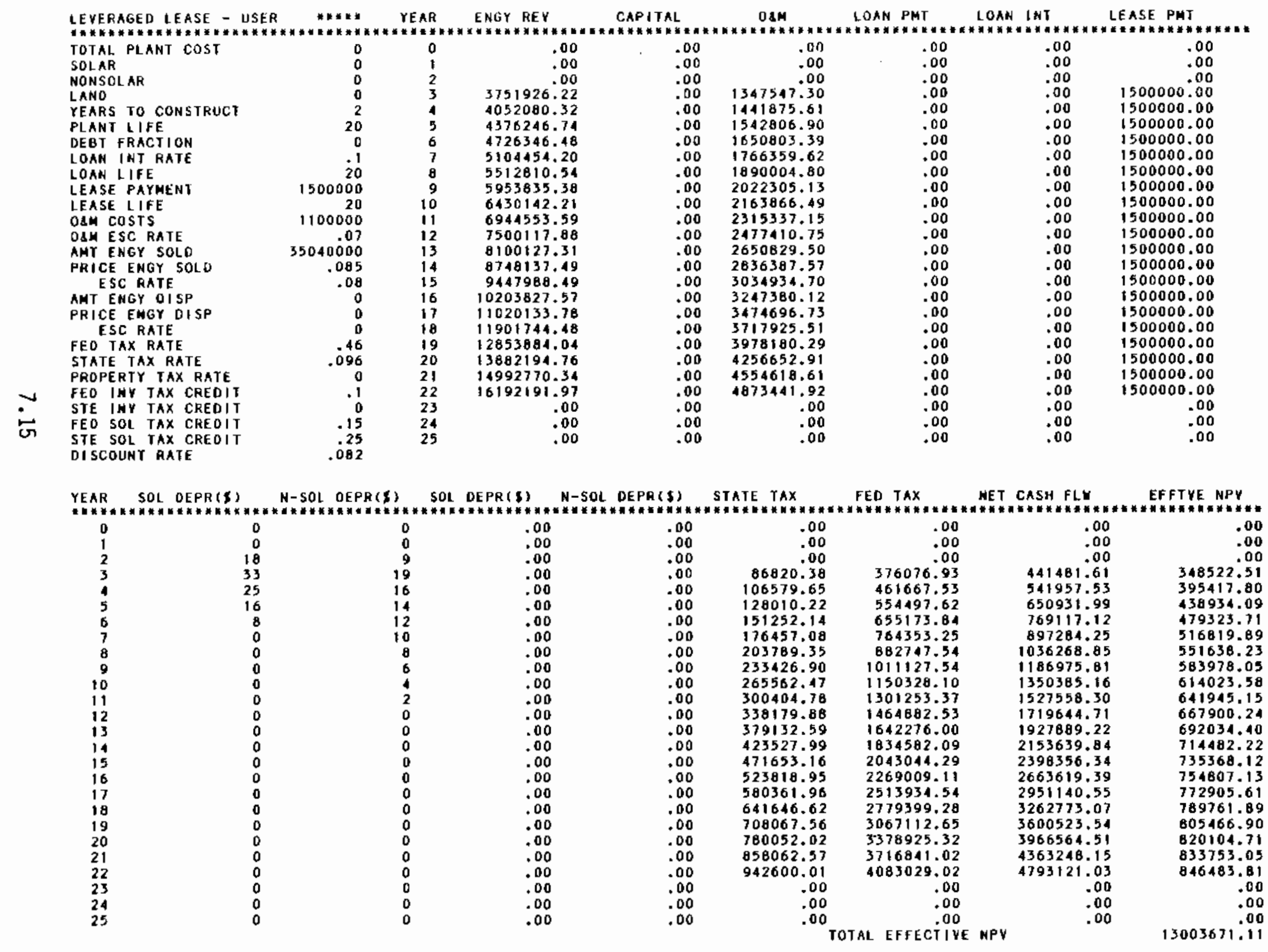


nominal amount in the last year of the lease when the user repurchases the plant from the investor corporation. The cash flows for the user (lessee) and owner (lessor) are shown in Tables 7.10 and 7.11. For proper operation of the cash flow model, the plant is assumed to be sold after completion in year 2 to the investor corporation at full cost (in nominal dollars). It is also assumed that the investor corporation borrows a portion of the money from the seller. This is the reason for the $-\$ 15$ million entry in the Capital column for year 2 (Table 7.10 ), which is equal to the $\$ 28.8$ million selling price minus the $\$ 13.8$ million construction cost for the year. The loan is handled separately and shows up in the net cash flow column.

In year 1, state taxes for the industrial corporation (user) are equal to the property tax on the plant after one year of construction and income taxes. In year 2, there are no taxes because the user no longer owns the plant and has no revenue. After this point, the only taxes are state and federal income taxes. Similar to the previous process heat illustrations, the energy revenue is that cost avoided by not having to use an alternative energy source (e.g., gas or oil). The same assumptions as before apply to the operating and maintenance costs, net cash flow, and effective NPV.

For the investor corporation (owner), year 0 corresponds to year 2 of the industrial corporation (user). The capital investment in year 0 (Table 7.11) for the investor corporation is the purchase price of the plant and this is also the base value for property taxes. As in Table 7.10 , the loan in Table 7.11 appears in the net cash flow column. The remainder of the entries in Table 7.11 are treated in the same manner as in previous illustrations. The cash flows shown in Tables 7.10 and 7.11 for industrial and investor corporations show (again) the large initial positive cash flows for the investor (owner) corporation due to the available tax credits and accelerated depreciation. The industrial corporation, by selling the tax credits and depreciation rights to the investor corporation, has effectively reduced its initial investment in the plant. This allows the industrial corporation to operate at an economic profit (NPV>0) over the plant life. 
TABLE 7.10. Cash Flow Analysis for Sale-Leaseback-User

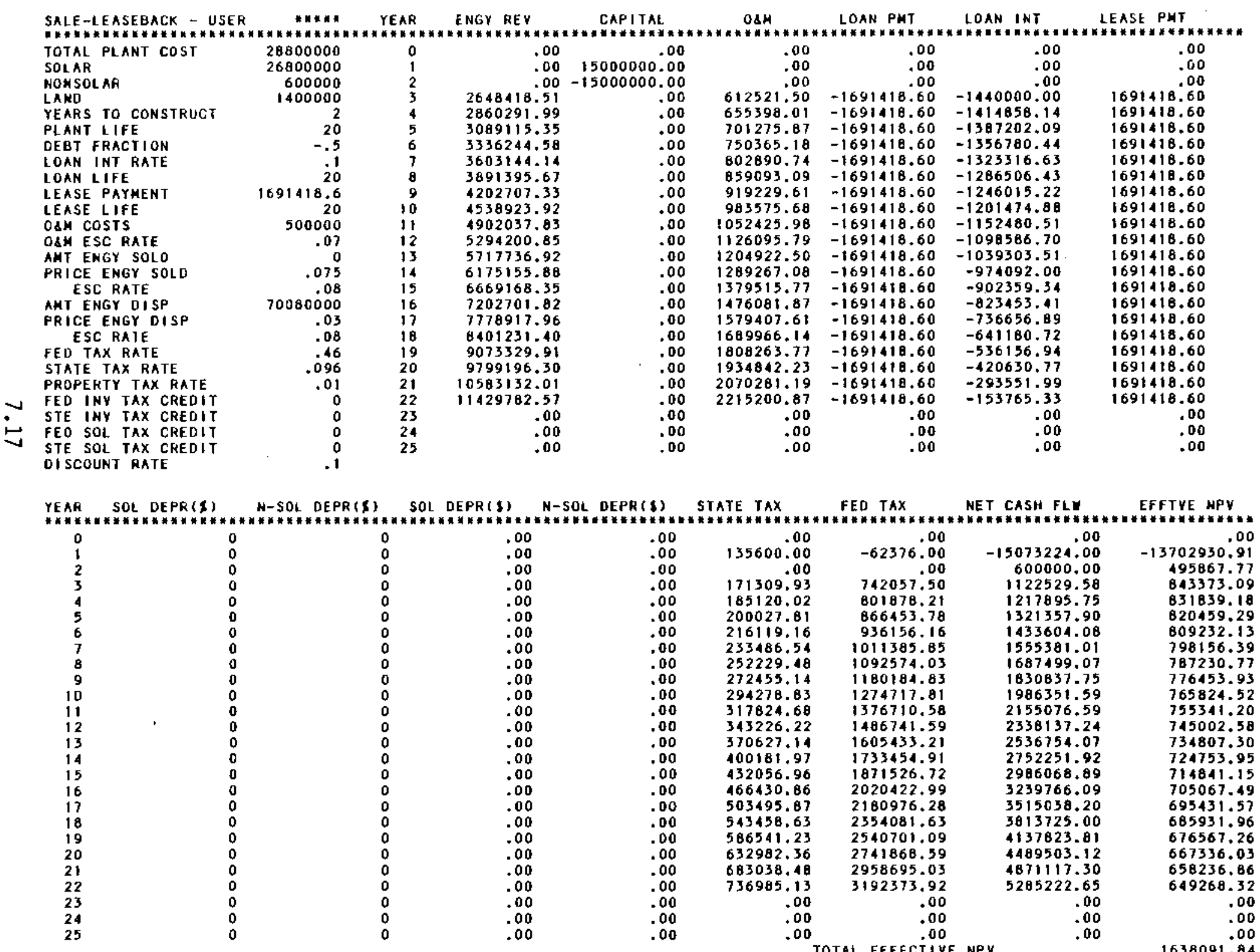


TABLE 7.11. Cash Flow Analys is for Sale-Leaseback Owner

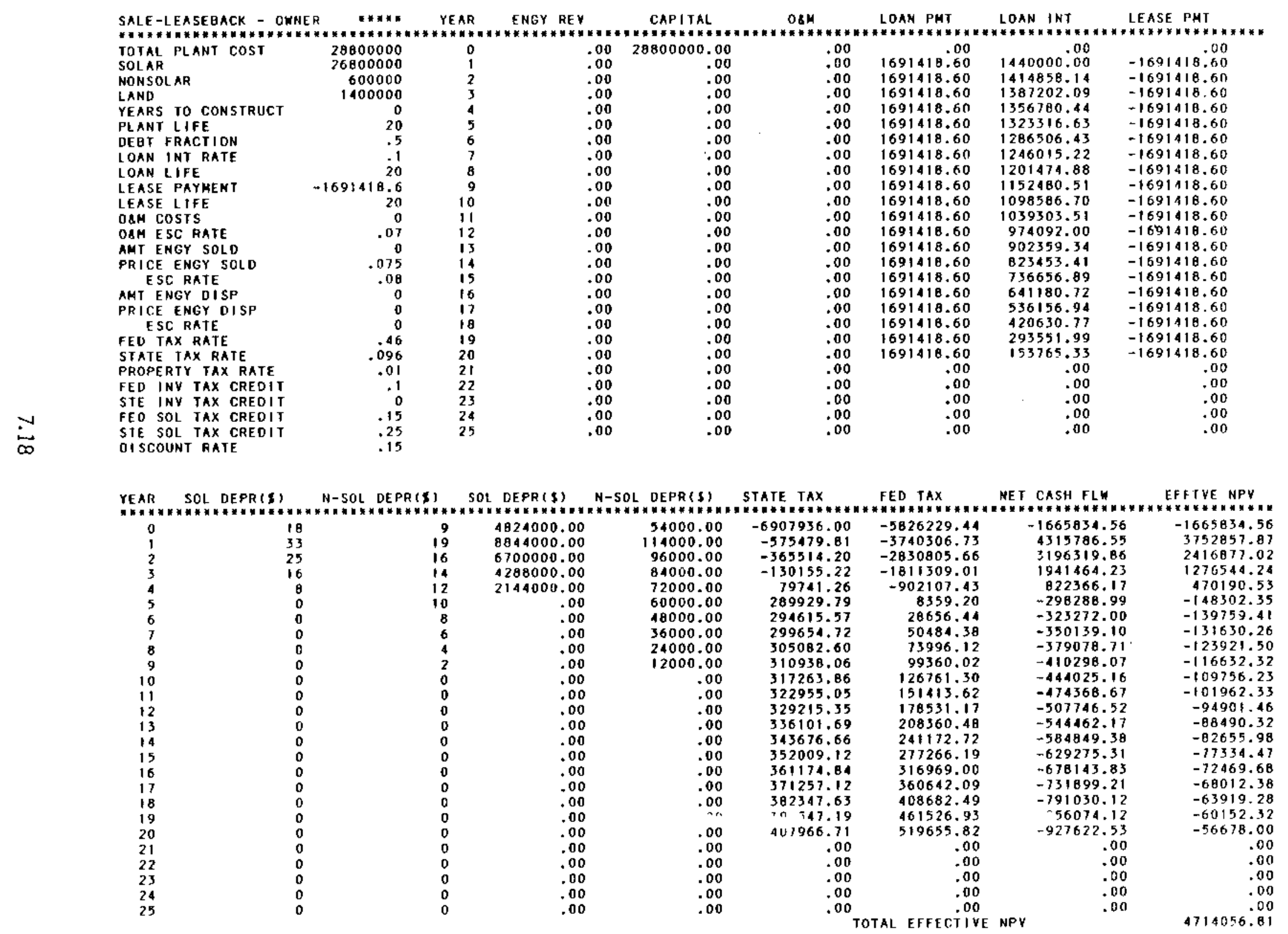




\section{2 .5 Industrial Revenue Bonds}

This example is identical to the sale with borrowed financing illustration except that the industrial corporation acquires financing from a municipality which issues industrial revenue bonds. The industrial corporation is both owner and operator and consumes the energy produced from the solar thermal process heat plant within its own facilities. The low financing rate associated with repayment of the municipal loan more than makes up for the loss of the federal solar tax credit. Project cash flows for the Industrial Revenue Bond case are shown in Table 7.12. The cumulative net present value of the project cash flows is always positive due to the $100 \%$ debt financing and availability of nonfederal solar tax credits. Additional positive cash flows accrue as the revenues climb and the loan is repaid over the plant operating life. 
TABLE 7.12. Cash Flow Analysis for Industrial Revenue Bond

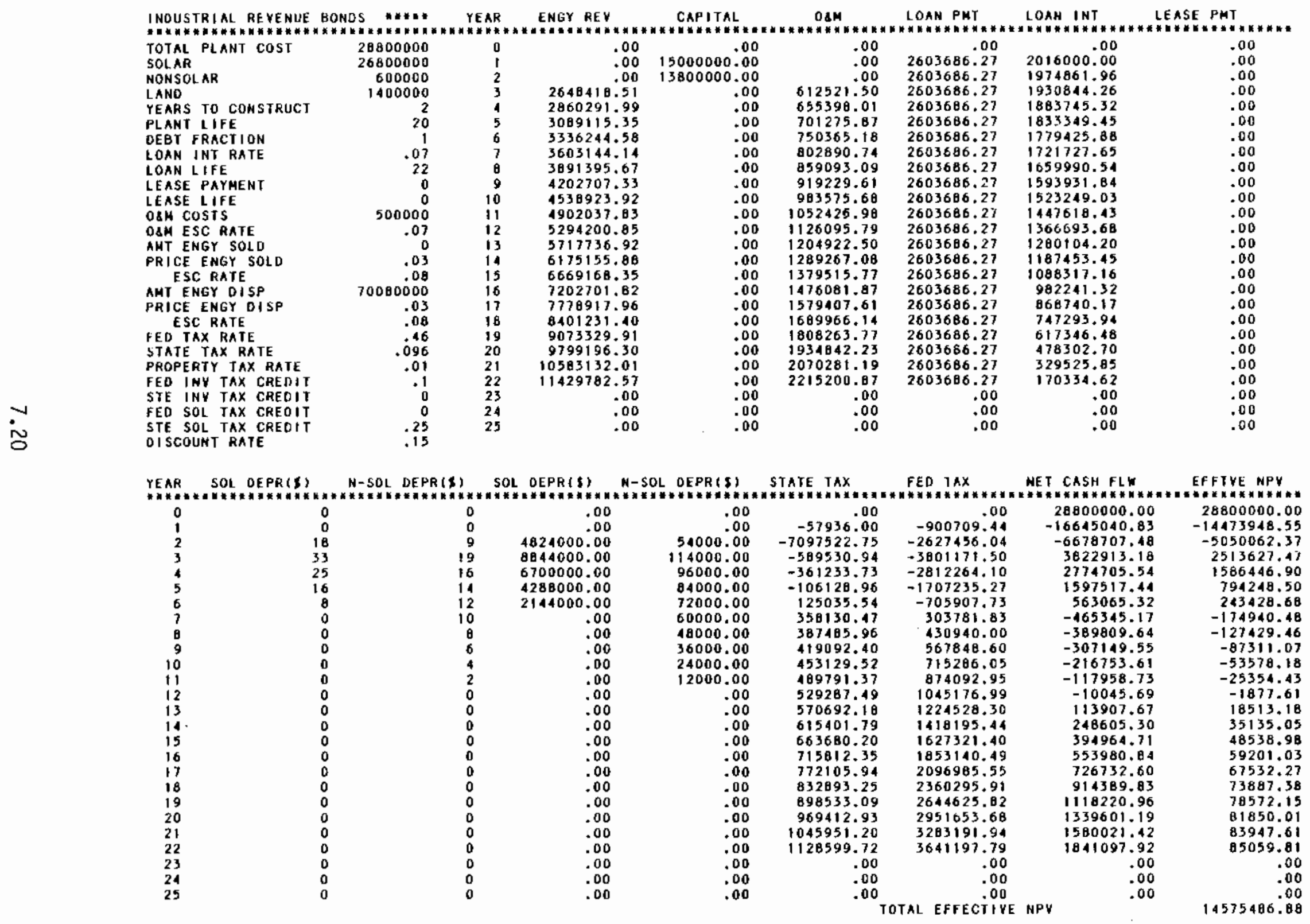




\subsection{GUIDELINES FOR ALTERNATIVE FINANCING}

Alternative financing for solar thermal projects can offer some significant advantages to project participants, but can also be difficult to properly evaluate and enact because of the complexities involved. The purpose of this chapter is to explain and help alleviate the difficulties involved in at least the initial stages of assessing and developing alternative financing packages by providing a set of general guidelines and considerations. These guidelines and considerations can minimize project evaluation time and maximize the chances of a successful project.

The first section of this chapter provides an overview of some of the important advantages and disadvantages of alternative financing. In the second section, important points regarding the analysis and packaging of solar thermal projects using alternative financing are discussed. The final section offers general guidelines for indicating whether alternative financing will be attractive for an individual.

\subsection{ADVANTAGES AND DISADVANTAGES OF ALTERNATIVE FINANCING}

One of the most important steps in the evaluation and development of solar thermal projects is an awareness of the alternative financing mechanisms that exist, as well as the inherent advantages and disadvantages of the mechanisms. In many cases, the advantages of alternative financing will be attractive enough to a potential project participant to warrant further investigation. For some individuals, however, the disadvantages of some mechanisms could be substantial enough that an early decision could be made not to investigate the options further.

One of the primary advantages of alternative financing is that, in many cases, it can provide a means of significantly enhancing the economic feasibility of an investment in a solar thermal facility. In general, alternative financing can improve the economics of a solar thermal plant when potential "problem areas" exist for an investor. These problem areas could be, for example, the inability to effectively use available tax credits, restricted capital investment funds, or a lack of desire to be involved with the operation 
of a solar plant. Alternative financing provides a means to involve others in the transaction who do not have the same problem areas as the original investor. For instance, if the original investor cannot effectively use all applicable tax incentives, the solution may be to involve someone in the transaction who can. Alternative financing can improve the economics of the investment by providing a mechanism to effectively share both the rewards and the costs of the solar project among the various project participants.

Alternative financing packages can also help to effectively allocate specific risks and benefits of the solar investment among the project participants. Allocation of risks among participants is obviously an important benefit. Some participants would decline involvement in the project unless it were relatively risk-free, while other participants would prefer a higher risk, providing that they anticipate adequate compensation for their risk. Allocation of the benefits of the project may also help to enhance the project's desirability. For instance, rather than owning and operating a solar plant, an investor group might prefer an option that would give them plant ownership while not requiring them to be involved in plant operations. Even if an option that involved operating the plant and selling the energy produced were more profitable, it could be less attractive to the investor group simply because they view themselves as investors rather than operators of power plants.

Several additional advantages are offered by alternative financing. Alternative financing can provide investment opportunities that would be unavalable using conventional methods. It can become an avenue to new sources of capital, and may lessen the drain on the company's borrowing capacity in some cases. A potential disadvantage of alternative financing is in the possibility of unconventional arrangements for the parties involved. The financing arrangements that result in the highest net present value may not conform to the practices of a particular company.

This guidebook has discussed project financing considerations largely from an economic point of view. Of course, alternative financing has major advantages and disadvantages in addition to strict economics. On the positive side, it can open access to capital and expertise not available in other forms of 
financing. Participation in alternative financing may also provide the opportunity for the individual or firm to operate in a different regulatory environment than would otherwise be possible. On the negative side, alternative financing packages can be very complex to analyze and very time-consuming to assemble. Time and great care are required in evaluating tax matters, presenting the necessary documentation, and negotiating deals. Because high risks are often attendant with project financing, lenders may require burdensome security arrangements; caution must be exercised in making final agreements. Parties who enter into project financing plans need to be willing to share decision making power, and to guard against potential conflicts among each other. The project manager is sometimes required to share control or ownership as well as the risk and return. These noneconomic considerations are very important and should be' carefully weighed (Perille 1978).

\subsection{ANALYSIS AND PACKAGING}

The analysis of alternative financing packages should be guided with a clear understanding of the benefits that are being sought through participation in the package. Many different benefits are associated with participating in a solar thermal project, and the attractiveness of the benefits will vary among the participants in the package. Examples of the different types of benefits are:

- A hedge against uncertain future conditions. The energy output from the plant provides the plant owner (or user) an energy source that is largely free from uncertainties regarding future cost increases or availability.

- Profit from plant operations. The plant owner (or user) can benefit by operating the plant and selling the energy produced at a profit. An alternative way to profit from plant operations would be to use the energy from the plant to displace other purchased energy when the production cost of energy from the solar plant is below the price of purchased energy.

- Profit from Plant Ownership. The plant owner may be interested in purchasing the plant as a profitable investment, but not in operating it or using the energy produced. The return to the plant owner in this case could come in the way of tax benefits and lease payments. 
- Using the tax benefits available from plant ownership. Tax benefits available to the owner of the plant include investment tax credits, solar tax credits, and accelerated depreciation of the plant. For some participants in alternative financing arrangements, the tax incentives may be the most significant benefit.

- Owning the plant as a positive public relations tool. Because of the popular sentiment toward solar energy, some plant owners could benefit from the positive publicity associated with owning a solar plant.

Paramount to the development of a successful alternative financing arrangement is a sound economic analysis. This analysis must incorporate the appropriate financial parameters and investor-specific tax considerations. Although this may be one of the most difficult and time-consuming steps in the process, the benefits can significantly outweigh the costs. A general procedure for performing the economic analysis is indicated in the following steps.

1. Defining the objectives of the solar thermal investment. Desirable options can be quickly determined by defining the objectives of a financing arrangement through a series of questions such as: Is minimum risk desirable, or is maximum return more important? Is capital availability a problem? Are all tax incentives available, applicable, and usable?

2. Identifying applicable tax incentives through reliable authorities. A proper understanding of the current tax laws is extremely important, since major income tax incentives are currently available for solar thermal systems. It is important to identify all of the tax incentives that could be applicable to the solar system under ideal ownership, identify the tax incentives that are available if the plant were owned by the company assessing the system, and determine if the company assessing the system could effectively use all tax incentives.

3. Defining economic and cost parameters and conducting project screening, including sensitivity analysis. Economic parameters include the discount rate, loan interest rates, escalation rates, and other parameters. Cost parameters include the capital cost of the solar thermal system, operations and maintenance cost, and sales prices (or values for) energy produced from the system. For purposes of screening analysis, it may be 
difficult to define all of the parameters with a high-degree of precision, and the effects of these parameters should be investigated through sensitivity analysis.

4. Investigating in detail alternatives that appear attractive in screening analysis. This investigation should include improving estimates of economic or cost parameters if significant uncertainty remains, and projecting a more detailed cash flow estimate for the project's lifetime.

As described above, the recommended procedure for analyzing a proposed solar thermal plant is to begin with a screening analysis and proceed to more detailed analysis if initial results are positive. Initially, many of the study parameters have large uncertainties associated with them. In order to maximize efficiency, the greatest effort should be spent refining those parameters that have the greatest effect on the project economics. The magnitude of any one parameter's impact on the projects net present value can be determined through sensitivity analysis. For a specific project, individuals should of course conduct their own sensitivity analysis, but some general information regarding the importance of different parameters is presented below. These points were obtained through sensitivity analysis on some of the case studies presented in Chapter 7.0

\subsubsection{Tax Credits}

The availability of tax credits significantly enhances the economic profitability of solar thermal projects and should be carefully examined. These creddits are currently available in three forms: state and federal solar tax creddits, and the federal investment tax credit. In the evaluation examples in Chapter 7.0, a large portion of the net present value for the owners is a result of tax credits. The impact of these credits is the same for all financing alternatives so long as the owners are eligible for them (e.g., municipally owned utilities pay no taxes and thus cannot use tax credits). It has been assumed throughout this guidebook that plant owners have sufficient income from other sources to fully use the tax credits in the year they occur. If this assumption is valid, the effective net present value could be improved by an alternative financing package, which involved someone who could effectively use the tax credits. Plant construction should be scheduled to take advantage of the 
maximum available credits if expiration of the credits is anticipated. It is important to plan completion of construction before, as opposed to after, the end of the year so that credits can be taken earlier and depreciation can begin a year sooner.

For the examples specified in Chapter 7.0, a sensitivity analysis indicates the economic importance of federal and state tax credits. A $10 \%$ reduction (e.g., 25\% to $15 \%$ or $10 \%$ to $0 \%$ ) in the state solar tax credit reduces the net present value of a process heat plant by about $\$ 1.1$ million. This effect would be twice as great for the electric plant because of the larger capital investments required. Reduction of the federal solar tax credit has a more pronounced effect on the net present value because of the deductibility of state taxes and the fact that the marginal federal tax rate is so much higher. In this case, a $10 \%$ reduction in the federal solar tax credit causes the net present value to decrease by about $\$ 2.0 \mathrm{million}$ for the process heat plant, with the effect again twice as great for an electric power plant. The same result would occur by eliminating the $10 \%$ federal investment tax credit.

\subsubsection{Initial Energy Price}

Initial energy price can have a major impact on the net present value of all parties selling or using the energy from a plant. Price will vary in each area of the country; however, it should be possible to define this parameter precisely for the purposes of screening analyses.

\subsubsection{Energy Escalation Rates}

These assumptions have a great effect on the net present value for all parties in the case examples that used or sold energy from a plant. Energy escalation rates are among the most important parameters and are very difficult to project for long periods of time. They are also a factor beyond the control of the individual who makes the investment decision. Energy escalation rates do not directly affect the owners in lease options, since they are not involved in energy sales or use. The absolute effect of energy escalation rates on the net present value of the Chapter 7.0 examples varies among the different financing arrangements investigated. 


\subsubsection{Discount Rate}

To obtain a meaningful result from the net present value analysis, it is essential to use a proper value for the discount rate. The appropriate discount rate is the opportunity cost of capital for investments of similar risk. Although this may be difficult to define, it is important to have a reasonable estimate. The effect of discount rate changes varies among the case examples because of the different cash flow patterns. An increase in the discount rate will increase the project's net present value for some options and will decrease it for others. Since positive cash flows may occur late in solar thermal projects, the attractiveness of the investment will improve with lower discount rates. The opposite is true for the plant owners in the lease options. These owners have large positive cash flows early on and negative cash flows later in the projects; thus, higher discount rates will increase net present values in these options. Caution should be taken to avoid using an artificially high discount rate to evaluate a project with large negative cash flows occurring far in the future.

\subsubsection{Loan Life and Interest Rate}

The effects of loan life and interest rate are greatest for highly leveraged cases. The relationship between the magnitudes of the discount rate and interest on debt is an important determinant of the project attractiveness. If the after-tax interest rate is lower than the discount rate, the net present value of the project can be enhanced by increasing the debt-to-equity ratio and/or lengthening the term of the loan.

\subsubsection{Initial Plant Cost}

None of the cases examined is extremely sensitive to the initial price of the plant because of the effects of tax credits and accelerated depreciation. The effect of the initial plant cost on NPV varies in magnitude among the alternatives examined. For the industrial revenue bond examples and the leveraged lease example, increasing the plant cost actually increases the net present value since the tax benefits are increased and the plants are heavily debtfinanced. The effect of a $33 \%$ increase in plant costs caused small drops in net present value for the sale with borrowed financing and sale-leaseback 
examples. The same $33 \%$ increase resulted in a significant decrease in net present value for the third-party lease example because no borrowed funds are used.

\subsubsection{Plant Lifetime}

Plant lifetime can be very important in cases that involve energy revenues with significant real escalation rates for the price (value) of energy. For any reasonable project, the longer the plant is in operation, the greater the net present value. Plant lifetime may not be an extremely significant parameter for cases in which the party does not receive energy revenues, or if the energy prices do not escalate at a rate greater than the rate of inflation.

\subsubsection{Initial Operating and Maintenance Costs}

The effect of initial 0\&M costs on the net present value of the case examples varies according to the ownership option. For plant users in lease options, 08M costs can have a significant affect on net present value because they are one of the major expenses for the plant user. When the plant is both owned and operated by the individual, O\&M costs are of somewhat less importance. For plant owners in lease cases, 0\&M costs have no direct effect on the owners' net present value.

\subsubsection{Thermal Versus Electric Energy Production}

A number of cost and performance considerations can make it more profitable to produce either thermal or electric energy, depending on the situation. A given size solar collector system could be integrated with other equipment to produce either process heat or electricity. The conversion of thermal energy to electric power involves losses due to thermodynamic constraints and other inefficiencies. However, the greater value of the electric power produced could make up for these losses. If electric power were three times as valuable as process heat and the thermal to electric conversion efficiency were $1 / 3$, then an investor would be indifferent toward process heat and electric power plants of the same size, cost, and thermal production. A number of possibilities can skew this relationship in favor of either thermal or electric production. Higher conversion efficiencies would favor electric power production, as would high electricity costs. Higher conversion efficiencies would allow for 
the production of more energy from the same solar collector investment, or allow a reduction in solar collector investment at the same electrical output. The converse of the above relationship is also true, and would serve to enhance a decision to produce process heat. The relationship of plant sizes, costs, conversion efficiencies, and energy prices can vary significantly for different technologies, locations, and users. The economic decision to produce process heat or electric power must be based on the specific conditions of the organizations involved.

\subsubsection{Surmary}

In summary, the important point in proceeding with an economic analysis, as defined in the steps given above, is that the analysis should be started from a broad perspective, and narrowed in scope if the broad analysis indicates the project may be feasible. Critical assumptions should be investigated in sensitivity analyses. This avoids potentially wasting resources by conducting an overly detailed analysis of a project that could have been ruled infeasible on the basis of general considerations or a simple screening analysis. If a project appears attractive throught the point of a detailed analysis, then serious negotiations should begin with other participants. In addition, when investor funds are in short supply and the timing of sales and expenses are not well matched, the project manager should prepare a more detailed economic analysis. This analysis should include a detailed projection of where cash will be received and when payments will be made.

\subsection{PROMOTIONAL PACKAGING}

An equally important aspect of developing a successful venture is the packaging of the proposal. Preparation of the proposal allows the project manager to once again review each aspect of the project to assure completeness. A well written proposal that includes a sound economic analysis will instill confidence in the potential investors. A number of publications discuss ways to prepare a project proposal; one proposal outline sample is presented below (Sholes 1974).

- Basic Proposition (1 page)

- Summary (2 or 3 pages) 
- Company (background on the company that would manage the project)

- Capitalization (sources of capital and background on the credit standing of the company that would manage the project)

- Product (description of the proposed solar thermal plant)

- Revenues (a discussion of potential energy revenue and the assumptions supporting those estimates)

- Marketing (a discussion of ways the package will be put together and the output agreements that have been or will be signed)

- Manufacturing (a description of the technical details on the construction and operation of the solar thermal plant)

- Organization (the organization chart of the project management and possibly of other parties already involved)

- Use of Proceeds (a description of how project funds will be spent)

- Historical financial statements (a discussion of the financial history of the company)

Successful promotion and packaging of alternative financial arrangements requires that the project manager perform detailed financial analysis that incorporates specific economic and tax considerations. The project manager must also consider outside investment opportunities, options available for changing or terminating project participation, and alternative sources of income of potential investors. The presentation of the investment opportunity can be improved by having a well written and comprehensive proposal.

\subsection{ALTERNATIVE FINANCING CONSIDERATIONS}

Several general considerations, much like traditional "rules of thumb", can be helpful when evaluating a solar thermal project using alternative financing. These considerations include both important factors to bear in mind when performing the economic analysis, and institutional factors, or factors that need to be considered external to the economic analysis.

As previously mentioned, individuals should investigate alternative financing for solar thermal projects any time there are incentives available that cannot be used effectively by the individual because of either legal or practical considerations. The most obvious incentives are the available tax credits and 
depreciation of the solar plant. For large projects the tax incentives may be so large (particularly for state tax credits) that many potential investors may have difficulty using the credits within a reasonable time period. In such cases, alternative financing should of course be considered, but an equally . attractive alternative may be to investigate building a smaller solar thermal plant. During preliminary project evaluation, care should be taken not to rule out alternative plant sizes or solar technologies without reason or investigation, or desirable alternatives may be eliminated.

When analyzing and developing alternative financing packages, individuals should avoid the trap of assessing the package only from their own perspective. Even though a particular factor may not affect the individual performing the analysis (such as O\&M costs for an individual who is analyzing being a solar plant lessor), the factor will certainly affect the attractiveness of the project to other participants (the lessee in the example above). If a package is to be successful, it must be economically attractive to everyone in the package, which requires a reasonable economic evaluation for all participants in the project.

In addition to the project-specific economic parameters, the project developer must also consider the specific needs of potential investors. The project manager should identify options for the transfer of ownership from one investor to another. For example, provisions could be made for converting all or portions of an investor's project interests from debt to equity. The original investor's interests could also be structured to allow purchase by others to provide some measure of liquidity. Provisions could also be made to assure investors that all steps are taken to facilitate future sales in accordance to security regulatory procedures.

An additional consideration for investors is outside investment opportunities, since these opportunities can significantly enhance the economic attractiveness of some arrangements. For example, the leveraged lease situation appears to be an attractive alternative since the lessor invests very little of his own money in the early part of the project. Instead, the lessor finances the project by relying heavily on borrowed funds. Since the lessor can deduct tax losses and use the various tax credits, he may receive large positive net 
cash flows in the first few years. However, once the tax credits are used, depreciation is completed, interest payments decline, and the net cash flows may become negative. Thus, the investor receives money from the project early that he will have to repay later. The benefits to the lessor from participation are the early positive cash flows and the return from investing these funds in other investment opportunities.

To expand the cohort of prospective investors, the project manager should enlist middlemen such as loan brokers, mortgage brokers, investment bankers, financial advisers and packagers. Soliciting this assistance will increase the likelihood that a commitment can be obtained within any alternative financing category. It can also lower the financing costs by promoting competition among potential investors.

A project promoter must consider a number of other institutional concerns in addition to the economic ones set forth in this guidebook. One is the credit worthiness of the proposed participants. Project financing generally works when at least some of the parties have outstanding credit ratings, even if those credit ratings are not directly involved in the enterprise. A second source of credit worthiness is the legal and economic links between the parties financing the project and those that sponsor it or use it. Strong ties between the parties can be a significant source of strength in seeing that a project is actually completed. Similarly, the project promoter also must consider some institutional as well as economic risks. One obvious institutional risk is that the project will not be completed. Another is that the project revenues will be insufficient, either because of technical deficiencies or because of pricing considerations imposed by the market or a regulatory authority. There are a number of means to protect the project against these financial risks. In the case of a public utility, one of these is an all-events full cost-of-service tariff--that is, agreement by the regulatory authority that the project would be allowed to recover its costs, whatever they were. (0f course, this guarantee applies only to projects involving a regulated utility or the equivalent.) Cost indexing and other contractual provisions may be established in order to deal with specific risks. The point to be made in conclusion is that these aspects of the arrangements need to be investigated as well as the cash flows involved in project financing (Lee 1977). 
As discussed in the earlier chapters, many of the parties are willing to undertake significant risk if the possibilities for return are high. For instance, a venture capitalist who is willing to undertake a very risky investment may want a return as high as fifteen times his investment within 5 years. If the risk is somewhat lower, a doubling or tripling over 5 years may be sufficient. Returns of this type are not currently projected from solar thermal projects, although to the extent that negotiated prices are keyed to the price of alternative fuels and appropriate financing packages are developed, they may sometimes occur. In general, solar thermal projects will be seeking situations that minimize risk and seeking parties satisfied with more moderate rates of returns (Sholes 1974 ).

Other considerations not already discussed relate to the process of obtaining appropriate governmental approvais. Delay in obtaining them can change the financial picture drastically. Thus, these permits and other governmental approvals constitute another institutional area needing careful consideration for a particular project (Castle 1975).

Project financing loans can be different from other loans in ways that need to be taken into account in analyzing a project. For example, lenders are usually able to obtain a higher interest rate on project financing than on direct loans made to sponsors. In addition, the maturity schedule of the loan should be set up so that it fits within the timing and amount of the project earnings. These factors affect the assumptions put into the model discussed in Chapter 6.0. In addition, those lending to the project may have special concerns with defaults and with collateral that are different from a nonproject loan. Specifically, they might want the assignment of any supply contract, sales agreement, sales contract, or other key contracts. The vendors might also want to be the beneficiary under insurance coverage on the project (Castle 1975). 



\subsection{REFERENCES}

Apley, W. J., et a?. 1980. Assessment of Generic Solar Thermal Systems for Large Power Applications, Vol. I: Analys is of Electric Power Generating Costs for Systems Larger than $10 \mathrm{MWe}$. PNL-3533, Vo T. I. Pacific Northwest Laboratory, Richtand, washington.

Bird, S. P., et al. 1981. Assessment of Generic Solar Thermal Systems for Large Power Applications, Vol. II: Analys is of Thermal Energy Production Costs for Systems from 50 to $600 \mathrm{MWt}$. PNL-3533, VoT. II. Pacific Northwest Laboratory, Richland, Washington.

Black, R. L., and J. H. Boyd. 1981. "Research Expenditures Take On New Impetus Under Provisions in the 1981 Act". Journal of Taxation. 55:348-356.

Brealeu, R., and S. Myers. 1981. Principles of Corporate Finance. McGrawHil1, New York, New York.

Castle, G. R. 1975. "Project Financing--Guidelines for the Commercial Banker". Journal of Commercial Bank Lending. 57:14-30.

Cole, R. J. and P. D. Tegeler. 1980. Government Requirements of Small Business. Lexington Books, Lexington, Massachusetts.

D'Ambrosio, C. A., and S. D. Hodges. 1981. Study Guide to Principles of Corporate Finance. McGraw-Hill, New York, New York.

Internal Revenue Code Sec. 44F(a).

Internat Revenue Code Sec. $44 \mathrm{~F}(\mathrm{~b})(1)$.

Internal Revenue Code Sec. 46(a)(2)(B).

Interna T Revenue Code Sec. 46(a)(2)(C)(i).

Internal Revenue Code Sec. $162(\mathrm{a})$.

Internal Revenue Code Sec. 167.

Internal Revenue Code Sec. 168.

Interna? Revenue Code Sec. 168(8)(B).

Internal Revenue Code Sec. 1974(a)(1).

Klepper, M., J. Sherman, and M. Carroll. 1982. Innovative Financing for Energy Efficiency Improvements - Phase I Report. Lane and Edson, P. C., Washington, D.C.

Lee, C. H., and T. J. Heal. 1977. "Project Financing of Large-Scale Energy Programs". Public Utilities Fortnightly. 99:17-22.

Patterson, J. M. 1981. R\&D Limited Partnerships--An Attractive Corporate Funding Alternative. Price Waterhouse, Inc., New York, New York. 
Perille, P. J. 1978. "Why Not Pro,ject Financing?" Management Accounting. $60: 13-16,22$.

Pubtic Law 95-95. Clean Air Act of 1977.

Public Law 95-620. Industrial fuel Use Act of 1978.

Public Law 97-34. Economic Recovery Tax Act of 1981.

Public Law 97-248. Tax Equity and Fiscal Responsibility Act of 1982.

Sholes, S. D. 1974. "The Search for Venture Capital--Preparatory Steps". Financial Executive. $42: 58$.

U. S. Congress, House. 1981. Tax Incentive Act of 1981. H. Rept. 97-201, 97th Cong., Ist sess., 113. U. S. Government Printing office.

Wilde, C. D., and W. C. Dickinson. 1981. Innovative Financing for Industrial Applications of Solar Technology. PNL-3718. Pacific Northwest Laboratory, Richtand, washington. 
APPENDIX A

ANNOTATED BIBLIOGRAPHY 


\section{ANNOTATED BIBLIOGRAPHY}

SOLAR THERMAL FINANCING

Boeing Engineering and Construction Company. Central Receiver Solar Thermal Power System Pilot Plant Cost Report, Volume VII. Collector Subsystem. SAN1111-1, Vol. 7. Seattle, Washington. May, 1977.

This report provides a breakdown of what costs would have to be considered in constructing a solar central receiver, 10 MWe solar pilot plant. Total progran costs and time projections as a function of costs are given.

Brown, Kenneth. "How to Determine the Cost-Effectiveness of Solar Energy Projects," Power 125 (March 1981):72+.

This article provides the data and methods needed to evaluate the. econony of using solar energy to supplement a process heating system, and to compare the costs and performance of solar-thermal systems with fossil-fueled systems. The key equations needed to determine solar cost-effectiveness are presented. In order to demonstrate how solar costs can be related to current and projected plant energy costs, four existing industrial solar projects are analyzed. The following assumptions are made in calculating rates of return on these solar investments.

\section{Tax Benefits}

In general, tax benefits are assumed to include the $10 \%$ federal investment tax credit, and the $15 \%$ federal energy tax credit, for a total federal tax credit incentive of $25 \%$. Additional state tax credits are accounted for in the relevant states. For a company in California, a $10 \%$ state investment tax credit is considered. In 0regon, a $10 \%$ investment tax credit in the first and second years of service and a $5 \%$ credit in each of the third through fifth years of service add up to a total of $35 \%$ credit on state income taxes.

\section{Other Parameters}

The following parameters are also set in the analysis. All systems are assumed to have a useful life of 20 years. The depreciation life is 12 years. The fuel price escalation rate is 0.1450 . Additional parameters defined in calculating rates of return include the capacity cost per year, operating cost fraction, and initial fuel cost. 
Copeland, R. J. Rough Cost Estimates of Solar/Thermal Coal or Biomass-Derived Fuels. SERI/TP-35-279. SERI, Golden, Colorado, 1979.

In this report, the cost of a hybrid technology combining a solar-themal heat source with either coal or biomass is compared with the cost of conventionally produced synthetic fuel. After an explanation of the production process, projections of costs are given. The costs of the fuels and the systems are analyzed in themselves, irrespective of parameters such as inflation rate, tax benefits, etc. The report concludes that a fuel produced by a hybrid technology becomes competitive with the same fuel made by coal or biomass, if future costs of coal and biomass are near the high end of projections, and if the cost of solar thermal heat can be reduced below current estimates.

Dickinson, W.C. et al. eds. "Economic Methodology for Solar Industrial Process Heat Systems." In Solar Technology Handbook, Part B-Applications, Systems, Design, and Dconomics, Pp. 685-703, New York: Marcel Dekker, 1980.

This report includes a methodology for analyzing the internal rate of return on a solar thermal system. Equations for calculating the rate of return are given. A set of baseline parameters is defined in order to establish a relationship between the real internal rate of return and the overall solar thermal system cost per unit collector area.

\section{Basic Parameters}

The assumed tax benefit used in the calculations is the $10 \%$ federal investment tax credit. (The additional investment tax credit of $15 \%$ provided in the Windfall Profits Tax is mentioned in a footnote). The expected lifetime of the system is set at 15 years. Other parameters defined in the analysis include the income tax rate, unit price of fossil fuel, net conversion efficiency from fuel to available heat at point of use, annual collected energy per unit effective solar collective area, overall cost per unit collector area, and loss of heat. Using these parameters, the real rate of return versus the installed solar system cost for three values of the annual collected energy is graphically represented. The payback period is also calculated and shown on the graph.

Effect of Inflation

The effect of inflation on the internal rate of return is considered separately. In this discussion, an inflation rate of $6 \%$ and a fuel escalator of $5 \%$ are assumed.

\section{Effect of Government Incentives}

In a section on the effect of government incentives, currently available incentives are defined as the federal investment tax credit, state tax credits, and property tax relief provided by some states and 
localities. Three additional possible incentives to industry are proposed: accelerated depreciation and increased investment tax credit; rebate on income tax liability due to savings of fossil fuel; and government-backed, low-interest loans. The potential effects of these incentives are calculated and presented graphically.

Doane, J. W. et al. Cost of Energy from Utility-Owned Solar Electric Systems. ERDA/JPL-1012-76/3. JPL. Pasadena, California, 1976.

The objective of this study is to provide a standard methodology for producing reliable rank orderings of the cost-effectiveness of alternative utility-owned solar energy systems. The methodology presented addresses the direct costs of purchasing, installing, and operating such an energy system, and derives the energy "price" necessary to recover those costs. The model developed is intrinsically a discounted cash flow approach. This method is designed to be used in on-going and future studies by ERDA and EPRI solar energy system contractors.

The model is composed of input data in several categories, including: system description data, utility description data, and general economic conditions. An illustration of the model includes the following nominal values:

$\begin{array}{lc}\text { System operating lifetime } & 30 \text { years } \\ \text { Inflation rate } & 0.05 \\ \text { Capital escalation rate } & 0.05 \\ \text { Operation escalation rate } & 0.06 \\ \text { Maintenance escalation rate } & 0.06 \\ \text { Income tax rate } & 0.40 \\ \text { Cost of capital to utility } & 0.08 \text {. }\end{array}$

The study gives equations for computing present values of capital investment; recurrent costs; annualized system resultant costs; and finally, the levelized electric energy busbar cost, which represents the minimum price per unit of energy consistent with producing system-resultant revenues equal to the sum of system-resultant costs. The report also gives general guidelines for categorizing costs when comparing different systems (cost account structure).

Edelstein, R. B. Solar Thermal cost Goals. SERI/TP-633-1063. SERI, Golden, Colorado. January 1981.

This paper describes the development of cost goals for the DOE Solar Thermal Program by the Solar Thermal Cost Goals Committee. The objective is to determine a consistent set of time-related cost and performance goals for concentrating collector systems based on market value, and intermediate goals based on attainable cost levels. 
A discussion is included of the disagreement over setting the proper financial parameters. While some advocate the use of historical data to determine return on investment, debt/equity ratio, etc., others believe in more conservative approaches such as a "hurdle rate" approach, including $100 \%$ equity financing for industry, and a "risk premium" for solar investments in the early years.

In this study, a conservative approach is chosen. Target markets are divided into two categories for the analysis: industry and utilities.

\section{Financial Parameters}

Fuel, capital cost, and 0\&M escalation rate assumptions for both cases are as follows:

$$
\underline{1980-85} \underline{1986-90} \underline{1991-2000} \underline{2001-2025}
$$

Rate of general inflation

Capital cost escalation rate 0\&M cost escalation rate

Fuel cost escalation rates Coa 1

$0 i 1$

Residual

Distillate and diese]

Natural gas
10.0

10.0

12.2

8.0

8.0

10.2

12.0

13.9

13.0

18.1

9.9

11.8

10.9

16.0
6.0

6.0

8.1

6.0

6.0

8.1

8.8

7.4
9.2

9.5

11.0
7.6

7.8

8.5

Financial Parameters for Industry Case

- 100\% equity financing assumed;

- $12 \%$ after-tax real rate of return on equity assumed for conventional fossil fuel cases;

- Diminishing "risk premium" for solar investment added to return on equity ( $5 \%$ in $1985,2 \%$ in 1990 , zero in 1995 , reflecting perceived riskiness of investment in early years);

- 25\% minimum tax credit through 1990;

- Accelerated depreciation from solar in 1985;

- In 1995, solar and conventional investments treated equally;

- 20-year service life.

\section{Financial Parameters for Utility Case}

- $8 \%$ after-tax real rate of return on equity;

- 50/50 debt/equity ratio;

- $10 \%$ investment tax credit;

- 30-year plant life. 
Fujita, T. et al. Techno-Economic Projections for Advanced Small Solar Thermal Electric Power Plants to Year 1990-2000. N79-23503. NASA Jet Propulsion Laboratory, Pasadena, CA, November, 1979.

In this report, the technology and economics of solar thermal electric power plants of less than ten MWe are assessed. The discussion is primarily technical, focusing on which technologies provide the most efficient power production. It is determined that two-axis tracking concentrators are the most promising and efficient technology.

In analyzing the economics of various small technologies, the authors utilize economic parameters that would be considered for large utility-owned systems. An operating lifetime of 30 years is assumed. Other parameters included are income tax rate, insurance premiums, annual rate of return on debt and on stock, and ratio of debt and stock to total capitalization.

Kaplan, G. Organization and Financial Plan for Solar Thermal Large Power Systems, SAND-78-8511. Department of Energy, Washington, D.C., November, 1978.

This report contains the highlights of information presented at a semiannual review of solar thermal large power systems by the DOE Division of Solar Technology. A number of papers are summarized in the report, including:

"A Technical and Economic Assessment of Solar Hybrid Repowering," by J. D. Maddox of the Public Service Co. of New Mexico. This paper analyzes solar hybrid units from a utility perpsective. The author conducted economic analyses of such systems in two separate tasks. In the first task, $0 i 1$ and gas-fired units of less than or equal to 200 MWe capacity were surveyed as potential candidtes for solar hybrid repowering. The second task involved a detajled economic assessment of one selected study unit with 50 MWe. The parameters set for analys is in the two tasks were as follows:

Fixed charge rate

$0 i l$ escalation rate

other fuel escalation rates

Operation and maintenance rates

Base fuel oil costs (1985\$)

Capital escalation rate

Useful life

\begin{tabular}{ll} 
1st Task & 2nd Task \\
\cline { 1 - 2 } $14.6 \%$ & $18 \%$ \\
$7 \%$ & $12 \%$ \\
$7 \%$ & $10 \%$ \\
$7 \%$ & $8 \%$ \\
4.63 & 5.50 \\
$7 \%$ & $10 \%$ \\
30 years & 30 years
\end{tabular}


Kreith, F. Technical and Economic Assessment of Three Solar Conversion Technologies. SERI/TP-34/262. SERI, Golden, Colorado, 1979.

In this study, the costs of three photovoltaic power systems are estimated, considering capital cost charges, and whether the system is proprietor or utility-owned. First, proprietor-owned residential systems are assessed. Cost effectiveness is examined at various fuel escalation rates, including $0.02,0.03,0.04,0.06,0.08,0.10$, and 0.12 . In a graph, cost-effectiveness is illustrated by plotting the composite electricity cost against the figure of merit for various differential interest rates. Also, the relative fuel cost escalation rate, i.e. the difference between the fuel escalation rate and the general rate of inflation, is illustrated for values of 0 to 0.08 , plotted against break-even array prices. A third table shows the estimated annual production of electricity needed to achieve cost goals, as well as associated system and electricity costs.

A technical discussion of solar thermal electric systems, solar industrial process heat, and thermal storage, with some cost analys is, follows. The report concludes that only direct solar thermal heat applications are currently economically viable.

Latta, A. F. et al. Effects of Regional Insolation Differences Upon Advanced Solar Thermal Electric Power Plant Performance and Energy Costs. DOE/JPL-1060-17. Jet Propulsion Lab, Pasadena, California, March, 1979.

This study determines the performance and cost of four 10-MWe advanced solar thermal electric power plants sited in various regions of the U.S. and conceptualized to begin in the year 2000. Regional variations in solar plant performance and cost are examined in relation to the expected rise in costs of residential and comercial electricity supplied by conventional utility power systems. The report concludes that two-axis tracking solar systems are potentially attractive in virtually all regions in light of uncertain future costs of other types of energy sources.

Three appendices provide details behind the economic and technical analyses. The first appendix sumarizes the aspects of insolation that must be considered in evaluating different themal power plant designs. The second appendix provides the performance and cost characteristics of advanced solar thermal plants. The following financial factors are taken into account: a system lifetime of 30 years; a $6 \%$ inflation rate, a $6 \%$ escalation rate for both capital and operating costs, and a $7 \%$ escalation rate for majntenance costs. A capital cost breakdown for selected systems is also provided. The final appendix includes parametric tradeoff and sensitivity analyses. Variations in the development of advanced technologies and levels of market penetration are considered. The tradeoffs involved in costs vs. efficiency of plants are discussed. Sensitivity to uncertainties in projections of energy conversion, operation, and storage system costs are analyzed. 
Lukens, L. L. Effect of Operating Temperature on the Cost of Energy from Solar Thermal Electric Power Plants. SAND-79-0801. Sandia Laboratories, ATbuquerque, New Mexico, July, 1979.

In this report, the effect of operating temperature on the annual cost of energy produced by a solar thermal system is evaluated for stand-alone solar and solar diesel hybrid power plants. The analysis is based on the following parameters: a system life of 20 years, $10 \%$ federal investment tax credit, $7 \%$ general inflation rate, $10 \%$ fuel inflation rate, fuel cost of .05-.15\$/kwh, and straightline depreciation. The general conclusion is that there is a decreasing reduction in annualized costs as system peak temperature is increased. Since it is likely that a system can be operated at lower temperatures without a serious decline in performance or increase in energy costs, it is suggested that other factors should be considered in designing a solar/electric system, such as maintenance fluid and surface degradation, and relative compound costs.

Munjal, P. K. and S. L. Leonard. Third-Party Financing of Photovoltaic Power Plants for Electric Utility Service. ATR-82(2828-01)-2nd. The Aerospace Corporation, El Segundo, California, January, 1982.

This study investigates possible third-party arrangements for financing the construction and operation of solar photovoltaic power plants whose output electricity is sold to the local utility. A third-party investor or investor group provides equity funding for the project, and takes advantage of tax incentives not available to utilities. A situation is considered in which a photovoltaic power plant is constructed on a desert site in Southern California.

\section{Economic Parameters}

Four different sets of economic parameters are applied to the situation. Several key assumptions remain constant in each of the four cases. These include an inflation rate of $7 \%$, a $12 \%$ interest rate on debt and equity reserve, and a depreciation period of 10 years. The parameters that vary from case to case include plant cost; the percentages of plant cost composed of equity capital, debt capital, and equity reserve; the real escalation of electricity price (ranging from $0 \%$ to 5\%); and the service life ( 30 years in the first three cases, and 20 years in the last case).

\section{Tax Benefits}

The tax benefits assumed in the analysis include the $10 \%$ federa? investment tax credit, the $15 \%$ federal energy tax credit, and a $25 \%$ state energy tax credit in California. (In lieu of the $25 \%$ state tax credit in California, depreciation may be taken in 1,3 , or 5 years.)

In order to assess the specific impacts resulting from federal and state solar tax credits, the median case is also computed without 
including the federal credit, and also without including either federal or state credits.

\section{Conclusions}

The analysis concludes that a third-party financial project would provide a very attractive investment opportunity, even at current possible prices for large systems. It is further suggested that the initiation of private sector construction of photovoltaic plants under the solar tax incentives could eventually result in sufficient decreases in photovoltaic module prices and system costs to allow continued expansion of the private market after the expiration of solar tax credits.

\section{Additional Data}

An appendix to the report provides graphs showing the time dependence of before-tax, after-tax, cumulative, and cumulative net-present-value cash flows for the cases analyzed.

Another addendum to the report lists and summarizes available federal and state tax benefits. In addition to those discussed above, it also notes the following tax benefits:

- Depreciation. Under the Accelerated Cost Recovery System in the Economic Recovery Tax Act of 1981, a solar photovoltaic system owned by a third party would qualify as a 5-year class property for depreciation. Compared to this, a utility owner of the same plant could only depreciate it over 10 to 15 years.

- Transfer of Credits and Depreciation. The Economic Recovery Tax Act of 1981 provides for the transfer of tax credits and depreciation allowances to corporations through safe harbor rules that, if met, characterize a transaction as a lease and allow credits and deductions to the nominal lessor.

- State Tax Credits. Other state tax credits besides those in California are noted. States with tax benefits favorable for renewable energy sources include Arizona (35\% tax credit until 1983, decreasing gradually until 1989, or depreciation over 3 years in lieu of a credit, and exemption of solar energy devices from property and business, sales, and excise taxes through 1989); Arkans as ( $100 \%$ deduction); Hawai ( $10 \%$ credit); Massachusetts ( $100 \%$ deduction); North Dakota ( $5 \%$ credit for each of 2 years); Ohio ( $10 \%$ credit); 0k lahoma (15\% credit); and Oregon (35\% credit--10\% for first two years and $5 \%$ for each of the next three years). 
"Tax Breaks Help Fuel Solar Power," Business Week, April 26, 1982.

This article describes a joint venture to get investors for a solar generating unit that will provide $12 \mathrm{Mw}$ of power for Southern California Edison. It discusses how solar tax credits are making such projects economically feasible.

Veziroglu, T. N. Solar Energy and Conservation Symposium-Workshop. CONF-781235-P1. Miami University, Coral Gables, Florida, 1978.

This report contains abstracts of various papers presented at a conference on solar energy and conservation. Relevant papers include:

- "A Life Cycle Model for Solar Heating System Design and Economic Evaluation," J. A. Clark, University of Michigan, Ann Arbor.

A model is presented which allows for design selection and economic optimization of a solar heating system in the U.S. It relates the life-cycle total cost to the fuel escalator, costs per unit area of collector, cost of capital, taxes, load factors, collector type, conversion efficiency of back-up system, and performance factors.

- "Life Cycle Costing and Pay Back of Large Scale Solar Heating Systems," L. O. Eckhoff, Federal Energy Corporation, Denver, Colorado.

In this paper, factors used in costing a large-scale solar system include investment, operating and maintenance costs; solar and backup energy supplied; tax costs and advantages; depreciation; and inflation.

- "Sources of Capital for Solar Electric Technologies," D. L. Harwood, Energy Economics and Alternatives, New York.

This paper examines the potential sources of capital for solar technology investments. The constraints, responsibilities, and objectives involved in investing funds obtained from 3 types of sources are discussed. The first type of source analyzed is private venture capital sources in the non-financial market, including energy companies; manufacturers of equipment and machinery sold to energy firms; utilities; users of utility-supplied electricity; and manufacturers of solar equipment. Secondly, private venture capital sources in the financial market are examined. These forms of borrowing include tax-exempt bonds, corporate bonds, mortgages, bank loans, comercial paper, acceptances, and finance-company loans. Finally, the possibilities for utility investment are discussed. 
Brealey, Richard and Stewart Myers. Principles of Corporate Finance. McGraw-Hi11. New York. 1981.

This book is a discussion of the major concepts and methods involved in corporate financing arrangements.

D'Ambrosio, Charles A. and Stewart D. Hodges. Study Guide to Principles of Corporate Finance. McGraw-Hi11. New York. 1981.

This is a guide to the Brealey and Myers publication on corporation finance, which distills and briefly describes the basic ideas presented in the book.

Dieter, Richard and Arthur R. Wyatt. "Get It Off the Balance Sheet," Financial Executive 48 (January 1980):42-48.

This article discusses financing methods that have been devised to remove debt from the balance steet. Methods described include nonconsolidation of finance subsidiaries, sales of receivables with recourse, product financing agreements, leases, project financing arrangements, utility take-or-pay contracts, and limited partnerships.

Erlandsson, Kjell and Gerald Rossow. "Investment Analys is Techniques for Energy Conservation Installations," Financial Executive 48 (December 1980):36-42.

This article presents the strengths and weaknesses of several basic techniques for financial analys is of energy conservation projects. The methods discussed are cash flow, payback analysis, and discounted cash flow. The authors argue that a sound financial analysis should include the time value of money.

"High-technology Park Dffers a New Financing Concept," Seattle Times, Apri1 18, 1982, p. H3.

This article discusses a new financing package being offered in an office/high technology park. The package is structured so that small companies can buy property for expansion. It covers the need for the lender to match the cost of its funds to the needs of the borrowers. Financing will be structured so a firm's owners, or a partnership of officers, can buy the property and lease it to their company, in order to take advantage of tax-sheltering benefits. 
Klepper, Martin, Joseph Sherman, and Megan Carroll. Innovative Financing for Energy Efficiency Improvements--Phase I Report. Lane and Edson, P.C. Washington, D.C. 1982.

This report examines six alternative financing techniques for energy conservation investments in three kinds of buildings: multifamily, commercial, and industrial. The six financing methods analyzed are energy service companies, utility assisted financing, tax-exempt bond financing, bank financing, leasing, and joint venture financing. The authors first discuss the factors which must be considered in making energy efficient investments in the three types of buildings. Then, the strengths and weaknesses of each financing method are evaluated. The application of each method to the various building types is also addressed. The study identifies a specific financing method for each building type that could be accomplished without subsidies from government or nonprofit foundations.

Lien, A. P. "Acquiring and Selling Technology--The Role of the Middleman," Research Management 22 (May 1979):29-31.

In this article, the special role of the middleman in facilitating the technology transfer process is discussed. The major objectives and activities of the middleman in this process are described. These include identification of needs, identification of assets, building bridges between sources and uses, and accelerating commercialization by bringing in associates.

Mentz, J. Roger, Mitcheel E. Menaker, and Emil G. Pesiri. "Leveraged Leasing and Tax-Exempt Financing of Major U.S. Projects," Taxes 58 (August $1980): 553-60$.

This paper provides an overview of two financing techniques for capital-intensive projects: leveraged leasing and municipal bond financing. The structures of these arrangenents are described, and the tax benefits and requirements are assessed.

Perille, P. James. "Why Not Project Financing?" Management Accounting 60 (October 1978):13-16,22.

In this paper, several major considerations in project financing are identified and discussed. Reasons for interest in project financing which are described include inadequacy of conventional funding sources; potential to open up supplemental sources of capital; ability to shift burden of financing to the project; and provision of investment opportunities not otherwise available. 
Roberts, Edward B. "New Ventures for Corporate Growth," Harvard Business Review, 58 (July-August 1980):134-42.

In this article, the attractiveness of new venture strategies is discussed. The major types of ventures, and their strengths and weaknesses, are described. Strategies examined include venture capital, venture nurturing, venture spin-off, new-style joint ventures, venture merging and melding, and internal ventures.

Wynant, Larry. "Essential Elements of Project Financing, "Harvard Business Review 58 (May-June 1980):165-73.

This article analyzes the effectiveness of project financing as a method to enlarge the amount of debt available to a new venture and to guard against risks. Subjects addressed include the assessment of start-up and operating risks; identification of loan sources and terms for obtaining funds; reduction of risks; achieving the leverage targets; structuring of ownership and credit arrangements; and financing costs. 
Black, Robert L. "Research Expenditures Take on New Impetus Under Provisions in the 1981 Act," Journal of Taxation 55 (December 1981): 348-356.

This article explains in detail the new R\&D provisions in the Economic Recovery Tax Act of 1981. The three provisions described are the 25\% tax credit for domestic R\&D; deductions for charitable contributions to research; and foreign income research allocations.

Feinschreiber, Nancy Abbott. "Apportionment of R\&D Expenses: The New Statutory Provisions," International Tax Journal 8 (October 1981):5-12.

This article focuses on the effects of the Economic Recovery Tax Act on aspects of international research and development and taxation.

Feinschreiber, Robert. "The Incremental Tax Credit for Research Activities (Provisions of the Economic Recovery Tax Act)," Tax Executive 34 (January 1981):155-162.

In this paper, the provisions of the Economic Recovery Tax Act as they relate to research activities and the various strategies available to the corporate executive are discussed. Examples for computation of the credit are given.

Feinschreiber, Robert. "Research Contracts Generate Tax Credit," Taxes 60 (March 1982):198-202.

This article examines the requirements of the Economic Recovery Tax Act for obtaining the tax credit for basic research and research contracts.

Ferrero, Henry J. "The New 25\% R\&E Credit--What is it Worth?" Tax Adviser (December 1981):735-37.

This article explains how the incremental feature of the research credit significantly reduces its incentive since the effective rate of the credit on additional dollars of current research and experimentation expenditures can be quite low. Illustrative examples of this effect are given. 
Mayer, Martin A. and S. Thomas Moser. "Reducing the Risk in Funding R\&D," Management Focus 29 (January-February 1982):39-40.

This article discusses the tax advantages available in R\&o limited partnership arrangements. It explains how the fomation of such partnerships can provide benefits to both the company and investors. The possibility of enhancing the tax benefits to limited partner-investors through the new ERTA provisions is also considered.

Moore, W. John. "Innovators Sel1 Major R\&D Tax Shelter, "Legal Times Vol. IV, No. 41, March 22, 1982, pp. 1, 8.

This article discusses the tax law issues surrounding a limited partnership that was established to take advantage of a large R\&D tax shelter. The two major issues are deductibility of the limited partnership's investment in the R\&D tax shelter, and treatment of royalty payments from sales of all products as long-term capital gains, rather than as income.

Padwe, Gerald. "Highlights of the Economic Recovery Tax Act of 1981," Tax Advisor 12 (November 1981):644-659.

This article explains the major tax subjects dealt with in the ERTA. Included are discussions of the new Accelerated Cost Recovery System, and the R\&D incentives in th law.

Patterson, J. Michae1. R\&D Limited Partnerships--An Attractive Corporate Funding Alternative. Price Waterhouse, Inc. September 1981.

This report examines the various considerations involved in the decision by a corporation formed by an inventor to utilize an R\&D venture in developing a new product. It focuses on financing and tax considerations, including the effect of the recently enacted Economic Recovery Act of 1981, and also the typical structure of the overall R\&D operation. The analysis is primarily concerned with the advantages to the corporate entity, both at the financing stage and the production stage.

Weiss, Jerold M. "Taxes--ERTA's Incentives for R\&O," Management Accounting 63 (February 1982):22,62. ERTA,

This article gives a brief outline of the three R\&D provisions in 
APPENDIX B

PERSONAL COMPUTER MODELS FOR EVALUATING AL TERNATIVE FINANCING FOR SOLAR THERMAL SYSTEMS 
APPENDIX B

PERSONAL COMPUTER MODELS FOR EVALUATING ALTERNATIVE FINANCING FOR SOLAR THERMAL SYSTEMS

This appendix documents the personal computer model employed in evaluating alternative financing for solar thermal systems. The first section provides some background information on computer spreadsheets and spreadsheet templates. The second section describes the development of a spreadsheet template based on the modeling equations developed in Chapter 6.0. The third section consists of sample listings of the display format and cell contents for two different software packages.

\section{Computer Spreadsheets}

Computer spreadsheets consist of a display of rows and columns on the screen that can usually be transcribed to paper by an attached printer. Invariably, computer spreadsheets have many more rows and columns than can be displayed on the screen (or normal size paper) at the same time. The computer has the ability to automatically "scroll" over to various sections of the spreadsheet, providing the user a "window" on the much larger set of rows and columns. The user can enter text, numbers, or formulas into each cell (row/column combination). Any cell can be a function of any cell or number of cells. This ability to make one cell the result of entries in other cells gives the spreadsheet its power. By using the spreadsheet, the computer operator can enter a set of new values in the input data sections of the spreadsheet, and calculate all new results in all other cells.

Strategy for Computer Template

The computer spreadsheet template aids in calculating cash flows and effective net present values for alternative financing schemes. Although the computer spreadsheet program simplifies data entry and manipulation, it does consume a large portion of the memory available in personal computers. Consequently, the analyst is Timited in terms of automatic calculations and display because of inadequate memory. This creates a tradeoff between how much data the user has to enter, how much information is contained in the display, and 
the memory available in the computer. Within the limitations imposed by computer memory, the goal is to have an area of the spreadsheet for user supplied input and then a series of columns that set out cash flows year-by-year for the length of the project. Indeed, the template even calculates the net present value of each net cash flow as it occurs, so one can see the year-by-year increments in the total net present value.

DISPLAY AND CONTENTS

This section describes the two essential components of the computer template: an output matrix (display) and the formulas used to generate the output matrix (contents). Output matrix cells contain all the relevant financial elements of alternative financing schemes. Some of the matrix cells are used to input the financial data, which, in turn, are used to compute the relevant financial data for other matrix cells. In addition, some cells of the matrix are reserved for column titles. The contents component is used to set up the output matrix with data inputs as well as to specify the procedures for converting the data inputs into other financial variables of interest and inserting them into appropriate cells of the matrix. The details of the display and contents component of the template are specified under two separate subsections below.

Display

The spreadsheet template output is displayed in the form of a matrix. In the template developed on this project, the output matrix consists of a $29 \times 19$ matrix which is shown in Table B.1. The 29 rows are identified by numbers ranging from 1 through 29 and the 19 columns are identified by letters from $A$ through $R$. Column and row identifiers are used to designate a unique cell number to each cell in the matrix. Accordingly, the cell call numbers from top to bottom for the first column $A$ are $A 1$ to $A 29$, for the second column are $B 1$ to $B 29$, and so on up to the 19 th column $R$. The top two rows, $A 1$ through $R 1$ and $A 2$ through R2, are used to specify column headings. The remaining cells are used for data inputs and the financial variables computed from those data inputs. Input data and computed data are described in turn below. 
$\underline{\text { Input Data }}$

Cells in seven columns--A, B, C, E, J, K, and L--are reserved for input variables.

Columns $A$ and $B$ are used to input the basic financial data concerning the solar thermal energy project of interest. For the model developed in this study, 27 separate variables are identified. The names of those variables are al ready entered in Column A cells (A3 to A29) and their corresponding values are to be entered by the user in Column B cells (B3 to B29). These variables and their values for one of the cases considered in this study are shown in the output matrix displayed in Appendix B.

Columns $\mathrm{C}$ and $\mathrm{U}$ are identical. They both are used to designate sequentially the years of construction and production phases of the solar thermal energy project. These year designators start with year zero--the beginning of the project--entered in cells C3 and J3, followed by one in cells C4 and J4 indicating the first year of construction, and so on up to year 25 in cells c28 and J28--the maximum combined length of construction and production phases that can be displayed in the template developed in this project. (Note: row 29 is blank from Column $C$ through R.) These columns serve as the year reference for the financial variable values shown in other cells of the output matrix, except for cells in column $A$ and $B$. Year designation is contained in two separate columins in order to improve the convenience of using the printed out version, in which the matrix is cut in half as shown in Tables B1 and B4. When printing, columns A through I are printed first, followed by columns $J$ through $R$.

Column E specifies the amount of capital invested in the solar project in the various years of the construction and production phases. Since most of the capital investment is likely to take place during the early years, entries in cells corresponding to subsequent years are zero.

Columns $K$ and $L$ contain the rates (percent) at which the solar and nonsolar capital can be depreciated during the construction and production phases of the solar project. The depreciation rate entries for solar and nonsolar capital to be entered in these columns are to be in accordance with internal Revenue Service (IRS) schedules for the 5 and 10 year accelerated cost recovery system (ACRS) for solar and nonsolar capital, respectively. 
In sumary, the following input variables are included in the output matrix:

- Column A: Input Data Variable Names

- Colurin B: Input Data Variable Values

- Columin C: Reference Year

- Columin E: Capital Expenses

- Column J: Reference Year

- Column K: Solar Depreciation Rate (percent)

- Columin L: Nonsolar Decreciation Rate (percent). Compounded Data

Input variables entered manually into Columns $A, B, C, E, J, K$, and $L$ will be used to compute variable values to be entered into the remaining columns of the matrix. Specifically, the following variables will be computed using algorithms specified in the contents component of the template:

- Column D: Energy Revenues

- Column F: Operation and Maintenance Expenses

- Column G: Loan Payments (Principal + Interest)

- Columin H: Interest Payments (Loan)

- Column I: Lease Payments

- Column M: Solar Depreciation Rate

- Columin N: Nonsolar Depreciation Amount

- Columin 0: State Taxes

- Column P: Federal Taxes

- Column Q: Net Cash Flow

- Columin R: Contribution to Net Present Value.

\section{Contents}

This subsection describes how the output matrix is prepared; i.e., the procedure for entering input variables and algorithms used to generate and enter variable values computed from the input data. Following the pattern of the previous subsection, we first describe the contents of the input data, followed by a description of the procedures used to develop the contents of the computed variables. 
Input Data

Columns $A$ and $B$ are used to enter input variable names and values, respectively. Variable names are already entered. The user of the template has to enter the corresponding variable values in Column B cells for each of the variables listed in Column $A$. The 1 ist of input variables in Column $A$ includes:

- Total plant cost

- Solar equipment cost

- Nonsolar equipment cost

- Land cost

- Length of construction phase

- Length of production phase

- Debt to capital ratio

- Loan interest rate

- Term of the loan

- Lease payments

- Term of the lease

- Operation and maintenance costs (first year)

- Operation and maintenance escalation rate

- Amount of energy sold

- Price of energy sold

- Escalation rate for price of energy sold

- Amount of energy displaced

- Price of energy displaced

- Escalation rate for price of energy sold

- Amount of energy displaced

- Price of energy displaced

- Escalation rate for price of energy displaced

- Federal income tax rate

- State income tax rate

- Property tax rate

- Federal investment tax credit

- State investment tax credit

- Federal solar tax credit 
- State solar tax credit

- Discount rate.

Columns $C$ and $J$ are used to enter the time horizon of the construction and the production phases. The template has been constructed for a 25-year horizon; however, it could be used even if the construction and production phase are shorter, as can be seen in evaluation examples presented in chapter 7.0. Each year of the 25-year time horizon is already entered in the cells of Column $C$ and $J$, starting with the reference year 0 in the top cells and reference year 25 in the bottom cells of both columns.

Column $E$ is for the amount of capital expenditure in dollars, which is to be entered by the user for each of the years of the construction and production phases as appropriate. Usually, capital expenditures are likely to be incurred only during the construction phase, but capital expenditures could be undertaken during the production phase to update the plant with a view to extend its life. The template is designed to accommodate such an eventuality.

Columns $K$ and $L$ are for solar and nonsolar depreciation rates, which are to be entered by the user. ACRS schedules ( 5 years for solar and 10 years for nonsolar) are to be used to specify the proportions of solar and nonsolar capital that can be depreciated during the first 5 and 10 years of the production phase, respectively.

\section{Computed Data}

Eleven separate variables listed in the previous subsection are computed by specifying an algorithm for each variable in the contents of the template. Algorithms used to compute these variables are discussed in turn below.

Energy Revenue The template permits energy revenues to be computed for each year of the production phase. The revenues displayed in the output matrix are the sum of revenues from both energy sold and energy displaced. Annual amounts of energy sold and displaced are both assumed to be fixed during the production period. As already indicated, separate prices and fixed annual price escalation rates can be specified for the two sources of energy revenue. Price escalation rates are used to compute prices for each year, which are 
multiplied by the amount of energy sold and displaced to generate revenue estimates from the two sources. The sum of these two revenue amounts for each year of the production phase are entered in those cells of Column D which correspond to the years of production phase (Columin C) and zero is entered in other cells of Column D; i.e., cells corresponding to the construction phase years and postproduction phase years. Algebraically, this computation can be summarized as follows:

$$
\begin{aligned}
\text { REV }_{i}= & \text { SLDAMT * PRSLD }(1+\text { SESC })^{i}+\text { DISPAMT * PRDISP }(1+\text { DESC })^{i} \\
& \text { if } i>\text { CYRS and DYRS } \geq j-\text { CYRS, }
\end{aligned}
$$

and

$$
\text { REV } i=0 \text { otherwise. }
$$

where REV $_{i}=$ Energy revenue in reference year $i$,

SLDAMT = Enerģy sold amount,

PRSLD = Price of energy sold at the start of the construction phase,

SESC = Fixed yearly price escalation rate for energy sold,

DISPAMT = Energy displaced amount,

PRDISP = Price of energy displaced at the start of the construction phase,

$D E S C=$ Fixed yearly price escalation rate for energy displaced,

$i=$ Reference year beginning with zero at the start of the construction phase,

CYRS = Length of construction phase in years,

OYRS = Length of operation phase in years .

Operation and Maintenance Costs. Dperation and maintenance (0\&M) costs for each year of the operation are computed in the template by specifying the $0 \& M$ costs at the start of the construction and applying a fixed yearly cost escalation rate to obtain 0\&M costs for subsequent years. Yearly 0\&M costs thus computed are entered in the cells of column $F$ corresponding to each year of production, and zero is entered in cells corresponding to the construction phase and post production phase. Algebraically, this computation can be summarized as follows:

$$
\begin{aligned}
O M C_{i}= & O M C_{0}(1+O M E S C)^{i} \\
& \text { if } i>\text { CYRS and OYRS } \geq i-\text { CYRS }
\end{aligned}
$$


and

$$
O M C_{i}=0 \text { otherwise. }
$$

where $O M C_{j}=$ Annual operating and maintenance cost in reference year $i$,

$O M C_{0}=$ Annual operating and maintenance cost at the start of the construction phase,

OMESC = Fixed yearly OM costs escalation rate.

other notations are the same as in the previous expression.

Loan Payments. The template computes annual loan payments based on the amount of the loan, loan interest rate, and the term of the loan which, as already indicated, are to be entered in input columns $A$ and $B$. Loan payments are computed to enable both the principal and the interest to be completely retired within the loan payment period through a series of equal annual loan payment installations. These payments are entered in cells of column G corresponding to the years over which the loan has to be paid. Zero is entered in the remaining cells of column $G$. The formula used to compute annual loan payment installments is:

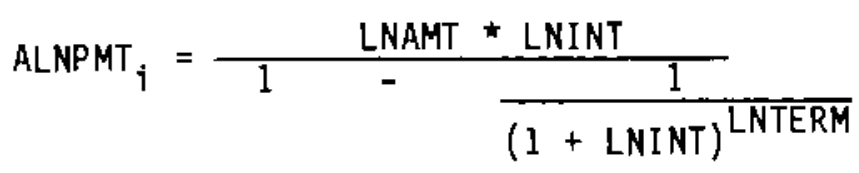

if $\mathrm{i} \leq$ LNTERM

and

ALNPMT $_{i}=$ Annual loan payment in reference $i$,

LNAMT = Loan amount,

LNINT = Loan interest rate,

LNTERM = Term of the loan.

other notations are the same as in previous expressions.

Loan Interest. Interest paid on the loan each year is computed by multiplying the amount of remaining principal in that year with the loan interest rate. The amount of remaining principal is determined by subtracting the principal retired to date from the original loan amount, i.e., the difference between loan payment and loan interest amounts paid to date. The loan interest amounts thus computed are entered in cells of Column $H$ corresponding to the 
years over which the loan has to be paid. Zero is entered in the remaining years over which the loan has to be paid. Zero is entered in the remaining cells of Column H. Computatation of annual interest paid on loans can be summarized as follows:

$$
\text { ALNINT }_{i}=\operatorname{LNINT}\left(\begin{array}{ccc}
i-1 & i-1 \\
\text { LNAMT }-\left(\sum_{i=1}\right. & \text { ALNPMT }_{i}-\sum_{i=1} & \text { ALNINT } \left._{i}\right)
\end{array}\right)
$$

if $i>0$ and $i \leq$ LNTERM

where ALNINT $_{j}=$ Annual loan interest amount in reference year $i$,

$$
\text { LNAMT }=\text { Loan amount, }
$$

LNINT = Loan interest,

Other notations are the same as in previous expressions.

Lease Payment. Annual lease payments are assumed to be fixed over the term of the lease. The annual lease payment amount specified in the input Columns $A$ and $B$ is entered in cells of Column I corresponding to the years during the term of the lease. Zero is entered in the remaining cells of column I. This means that lease payment in each year is computed as follows:

$$
\begin{aligned}
\text { LSPMT }_{i}= & \text { LSPMT } \\
& \text { if } i>\text { CYRS and } i<(\text { CYRS + LSTERM + 1) } \\
\text { LSPMT }_{i}= & 0 \text { otherwise }
\end{aligned}
$$

where LSPMT $_{j}=$ Annual lease payment amount in reference year $i$,

LSTERM = Term of the lease.

0ther notations are the same as in previous expressions.

Solar Depreciation. Entries for annual solar depreciation are computed by applying the ACRS rate by year (specified in input Column K--solar depreciation rate) on the solar capital expense of the project (entered as input in Columns $A$ and $B$ ); i.e, annual solar depreciation amount is a product of ACRS rate and the solar capital expense. Annual solar depreciation amounts are entered in cells of Column $M$ corresponding to the years required to completely depreciate the solar capital expense; i.e., 5 years. Zero is entered in the remaining cells of Column $M$. This procedure for computing and entering solar depreciation values in the display matrix can be summarized as 


$$
\text { SDEPAMT }_{j}=\text { SDEPRT }_{i} * \text { SCAP } / 100
$$

where SDEPAMT $_{\mathbf{i}}=$ Solar depreciation amount in reference year $i$,

SOEPRT $_{\mathbf{i}}=$ Solar depreciation rate in reference year $i$,

$$
\text { SCAP = Solar capital expense. }
$$

Nonsolar Depreciation. Depreciation on nonsolar capital is computed in the same way as the solar depreciation but by applying the nonsolar instead of the solar depreciation rate schedule. The computed annual depreciation amounts are entered in cells in Column $\mathrm{N}$ corresponding to the years over which depreciation on nonsolar capital expenses can be claimed; $1 . e ., 10$ years. Zero is entered in the remaining cells of Column $N$. The procedure for computing solar depreciation values can be summarized as follows:

$$
\text { NSDEPAMT }_{i}=\text { NSDEPRT }_{i} * \text { NSCAP } / 100
$$

where NSDEPAMT $_{j}=$ Non-solar depreciation amount in reference year $i$, NSDEPRT $_{j}=$ Non-solar depreciation rate for reference year $i$, NSCAP = Non-solar capital expense.

State Tax. For computation of annual state tax, three distinct components are considered: net revenue, property tax and investment tax credits.

Net revenue is computed by subtracting $0 \& M$ costs, interest, lease payments, state property tax, and allowed depreciation on both solar and non-solar capital from energy revenue. Tax on net revenue is computed by applying the state tax rate (entered as input in Columns $A$ and $B$ ) to the net revenue amount. property tax is computed by applying the state property tax rate (entered as input in Columns $A$ and $B$ ) on total capital expenses that are entered as inputs in column E. Investment tax credits are computed by applying the state investment tax credit to the solar and nonsolar capital amount and applying the state solar investment tax credit to the solar capital amount. Investment tax credits are obtained only once--upon completion of the construction phase.

State taxes on net revenue and property taxes are summed to obtain the amount of annual state taxes except during the year in which construction is completed; during that year the state taxes are reduced by the amount of investment tax credits. Note that during the construction phase, the owner receives tax credits for interest expenses and has to pay property taxes on capital already acquired. As a result, during this period, the owner's tax liability 
may be smaller than tax credit due to him on the solar project, in which case he has the option of offsetting the tax credits against other tax liabilities he might have. A situation of net tax credits is displayed in the output matrix as a negative number. Annual state taxes thus computed are entered in cells of Column 0 against corresponding reference years during the construction and the production phases. The computation of annual state taxes can be summarized as follows:

$$
\begin{aligned}
& \text { STTX }_{i}=\left(\text { REV }_{i}-\text { OMC }_{i}-\text { LNINT }_{i}-\text { LSPMT }_{i}-\text { SDEPAMT }_{i}-\text { NSDEPAMT }_{i}\right) \text { * STTXRT + } \\
& \left(\sum_{j=0}^{i} \mathrm{CAP}_{j} \text { *PRTXRT) *(1-STTXRT)-SCAP }{ }_{i} \text { *STSINCR }-\left(\operatorname{SCAP}_{i}+\right.\right. \\
& \left.\operatorname{NSCAP}_{j}\right) * \operatorname{STINCR}
\end{aligned}
$$

where STTX $_{i}=$ Annual state tax in reference year $i$, STTXRT = State taX rate,

$\mathrm{CAP}_{j}=$ Capital expenses in reference year $j$, PRTXRT = Property tax rate, SCAP $_{i}=$ Solar capital expenses in reference year $i$, NSCAP $_{j}=$ Nonsolar capital expenses in reference year $i$, STSINCR = State solar investment credit rate, STINCR = State investment credit rate,

Other notations are the same as in previous expressions.

Federal Taxes. Federal taxes are computed in the same way as the state taxes with the following two differences: (1) state taxes are allowed as deductions and there is no property tax, and (2) taxes are paid on net revenues and investment credits can be claimed upon completion of construction. Annual federal taxes are entered in the cells of Column $P$ corresponding to years during the construction and production phases. Zero is entered in the remaining cells of column P. Computation of federal taxes can be sumarized as follows:

$$
\begin{aligned}
& \text { FDTX }_{i}=\left(\text { REV }_{i}-\text { OMC }_{i}-\text { LNINT }_{j}-\text { LSPMT }_{i}-\text { SOEPAMT }_{i}-\text { NSOEPAMT }_{i}-\text { STTX }_{i}\right)
\end{aligned}
$$

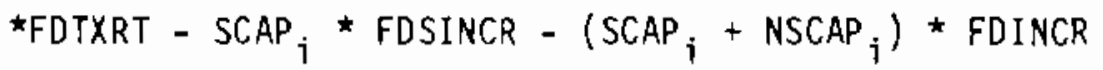


Net Present Value. Net present value is computed by summing the contribution to net present value of the cash flow for each year of the construction and production phase years. Contribution to net present value for each year's net cash flow is obtained by discounting the net cash flow amount by the discount rate specified as input in column B. Computed contributions to net present value for various years are entered in the cells of Column $R$ corresponding to the years during the construction and production phases. Zero is entered in the remaining cells of column $R$ except cell $R 29$ in which the net present value; i.e., sum of contributions from various years is entered. The computation of net present value can be summarized as follows:

$$
\text { CNVP }_{i}=\frac{\text { NETCF }}{(1+d)^{i}}
$$

and

$$
N P V=\sum_{i=1}^{n} C_{i} N V_{i}
$$

where $\mathrm{CNPV}_{i}=$ Contribution to net present value of net cash flow in year $i$, $\mathrm{d}=$ Discount rate, NPV = Net present value of the project.

other notations are the same as in previous expressions.

Sample Display Format and Cell Contents

This section contains sample listings of the display format and cell contents for two different software packages. The display format, shown in Table B.1, shows model input data and the results of the analysis for a specific case. The cell contents are shown in Tables B.2 and B.3 for Supercalc* and Visicalc* software packages, respectively. The contents of each cell show the equations used to calculate the results of each cell. The methodology should also be readily adaptable to other software packages, although the specific format of the equations would change.

The power of the model is considerably enhanced by the fact that many basic assumptions regarding the cash flows can easily be modified to allow

* Supercalc is a trademark of Sorcim Corporation. * Visicalc is a trademark of Visicorp. 
TABLE B.1. Standard Model Display Format

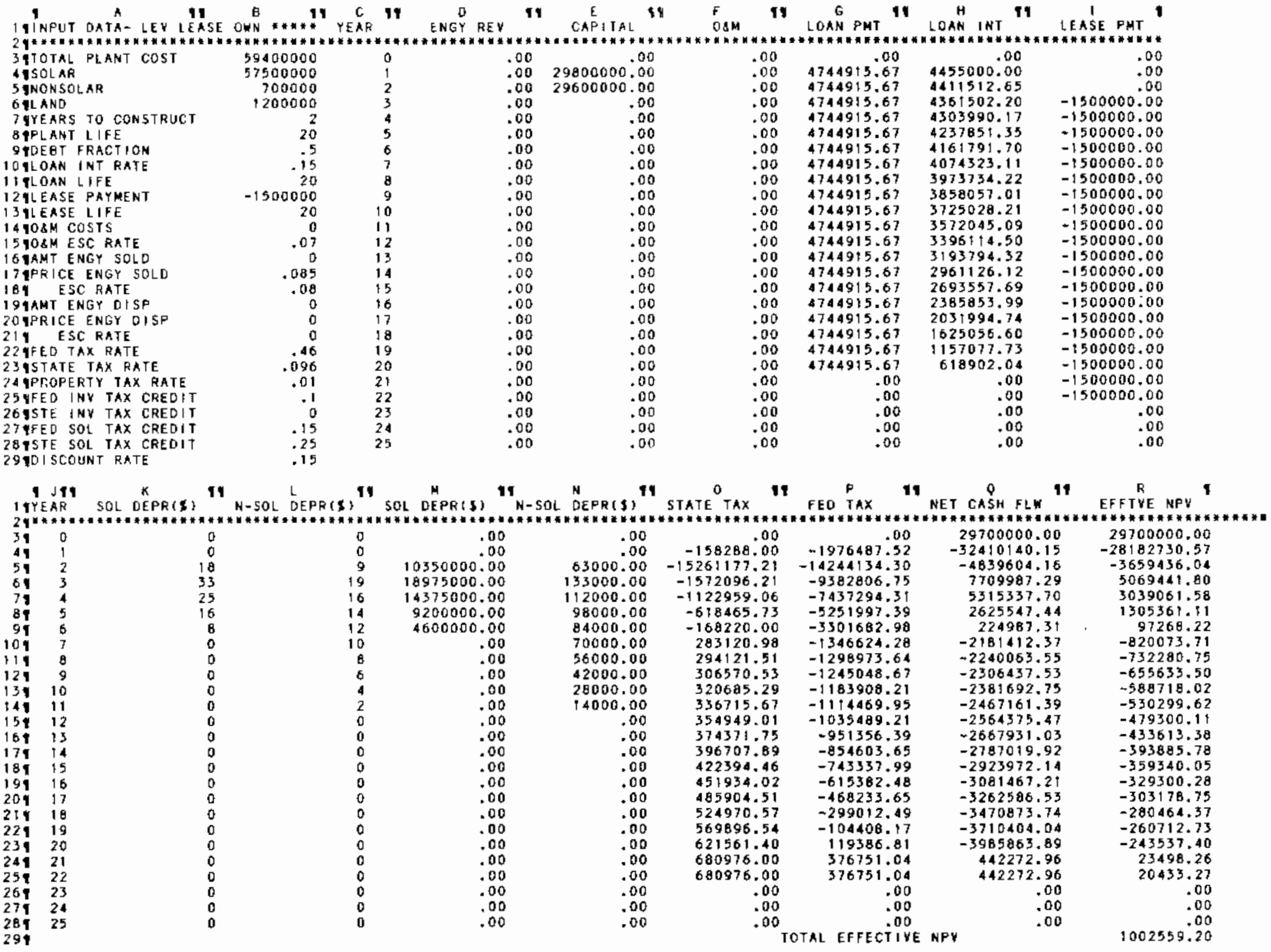




\section{TABLE B.2. Standard Model Cell Contents - Supercalc Version}

Supercalc ver. 1.05

INPUT DATA- LEY LEASE DHM *****

A1 $=$ "INPUT DATA- LEV LEASE OHA "*****

DI $="$ ENGY REV

FI $="$ D D\&M

61
HI
HI

$11=n$ LEASE PMT

J1 $=$ "YEAR

LI $=$ "

MI $=$ " SOL DEPR(S)

N1 $=" N-S D L$ DEPR( $\$$ )

$01 \quad="$ STATE TAX

Q1 = NET CASH FEN

R1 = " EFFTYE MPY

A2 $=1+101$

$=$ "TOTAL PLANT COST

$=59400000$

$=0$

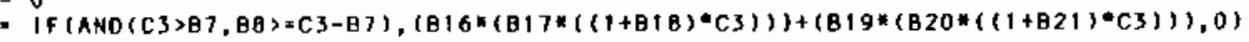

$=\operatorname{IF}($ AND $(C 3) B], B \theta)=C 3-87), B 14=((1+B(5) \cdot C 3), 0)$

$=0$
$=0$
$=0$

$=$ If (AND $(C 3>B 7, C 3<B 7+B\{3+1), B\{2,0)$

$=c 3$

$\begin{aligned}= & 0 \\ & =0\end{aligned}$

- $\mathrm{K} 3 * \mathrm{~B} 4 / 100$

$=K 3 * B 4 / 100$
$=13 * 85 / 100$

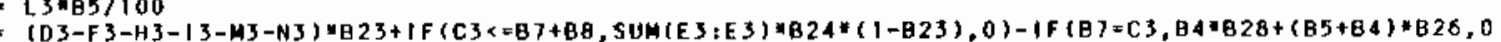

$=(D 3-F 3-H 3-13-H 3-N 3-03) * B 22-1 F(B 7=C 3, B 4 * B 27,0)-1 F(B 7=C 3,(B 5+B 4)=B 25,0)$

$=D 3-E 3-F 3-G 3+13-03-P 3+1 F(C 3=0, B 9=B 3,0)$

$=Q 3 /(\{t+B 29) \cdot C 3)$

$=-\$ O L A R$

ST500000

$=$ IF IANDCLA

$=29800000$

$=$ If $(A N D(C 4>B 7, B 8)=C 4-B 7), B 14 *(\{1+B(5) * C 4\}, 0\}$

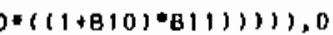

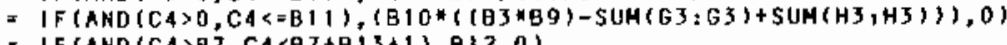

CA IFANDCA

$=0$

$=0$

$=K 4 * 84 / 100$

$=L * 85 / 100$

$=(D 4-F 4-H 4-(4-M 4-N 4) * B 23+1 F(C 4<=B 7+B 8, S U M(E 3, E A) * B 24 *(1-B 23), 0)-(F(B 7=C 4, B 4 * B 28+(B 5+B 4) * B 26,0)$

$=(D 4-F 4-H 4-14-M 4+N 4-04) * B 22-I F(B)=C 4, B 4 * B 27,0)-1 F(B 7=C 4,(B 5+B 4) * B 25,0)$

$=04-E 4-F 4-G 4-14-04-P 4+P F(C 4=0,89 * 83,0)$ 


\section{TABLE B.2. contd}

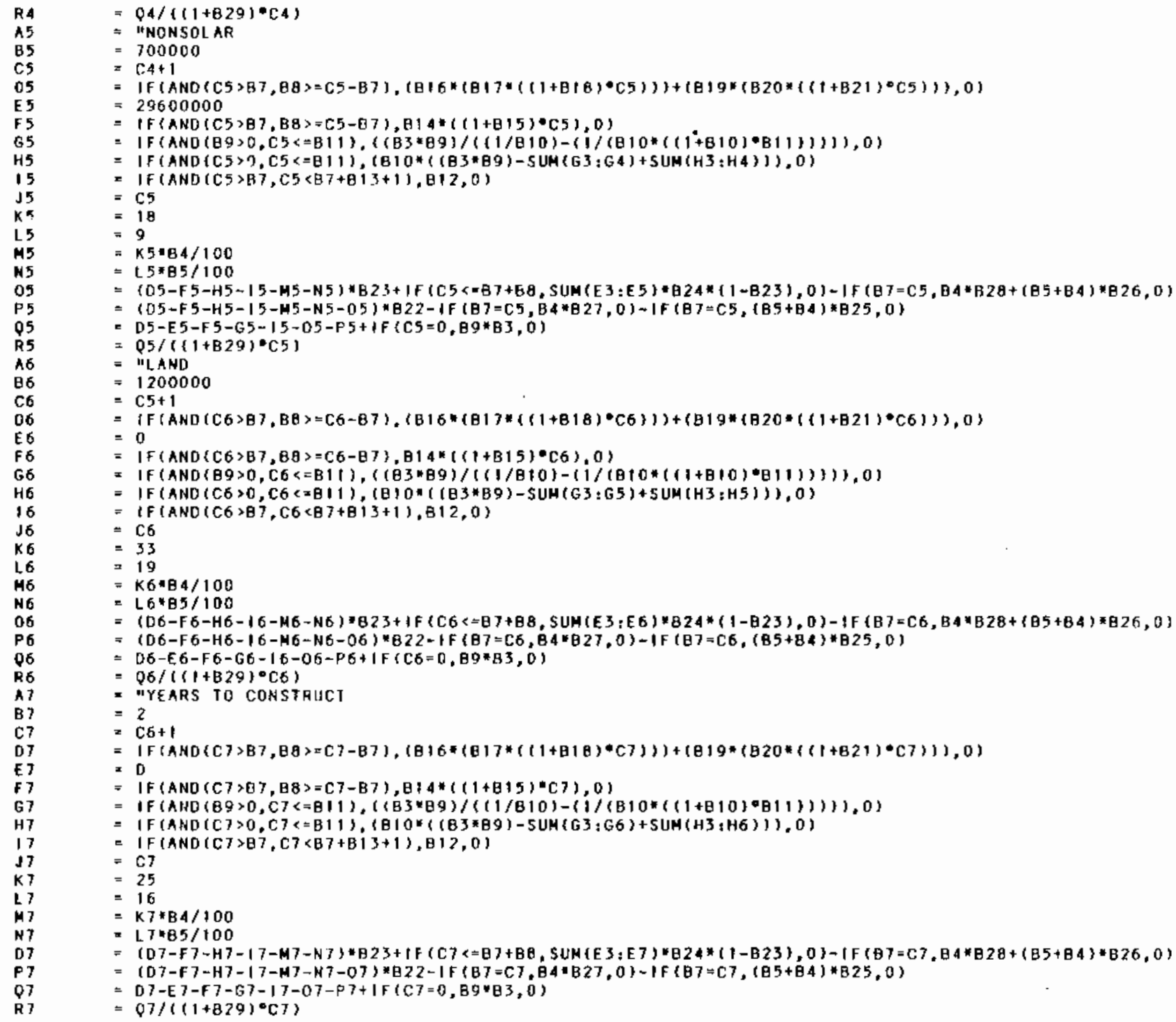




\section{TABLE B.2, contd}

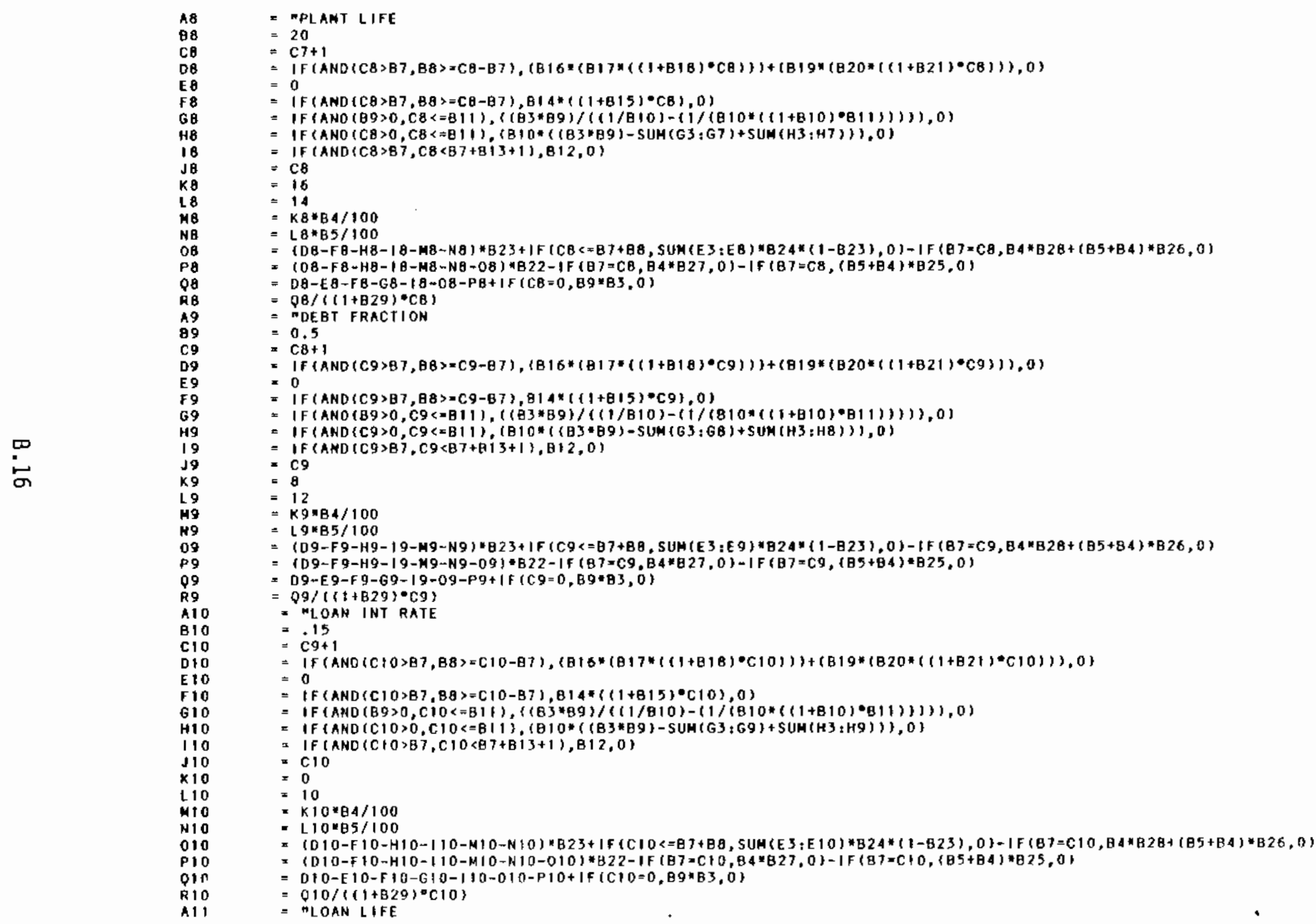


TABLE B.2. contd

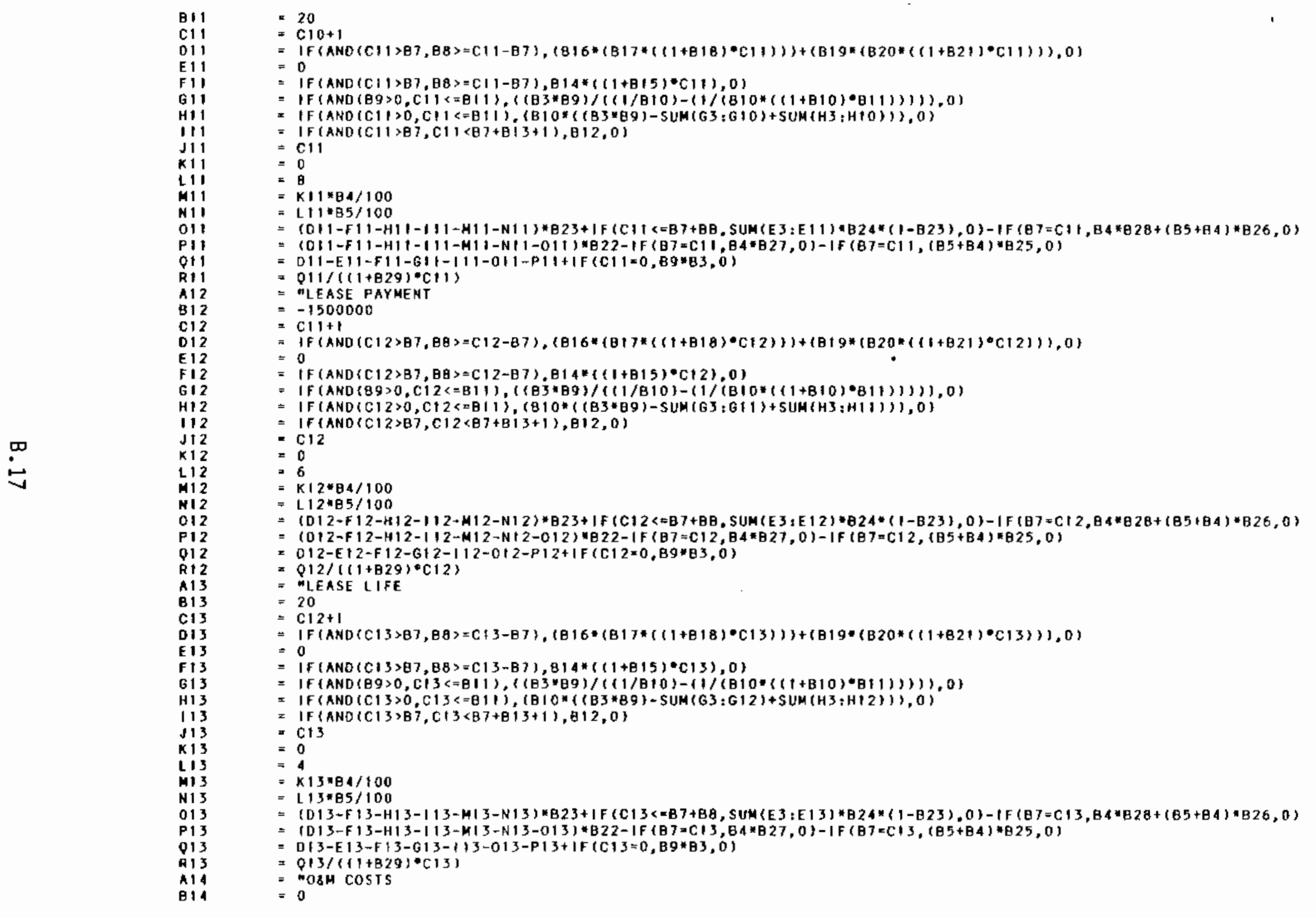




\section{TABLE B.2. contd}

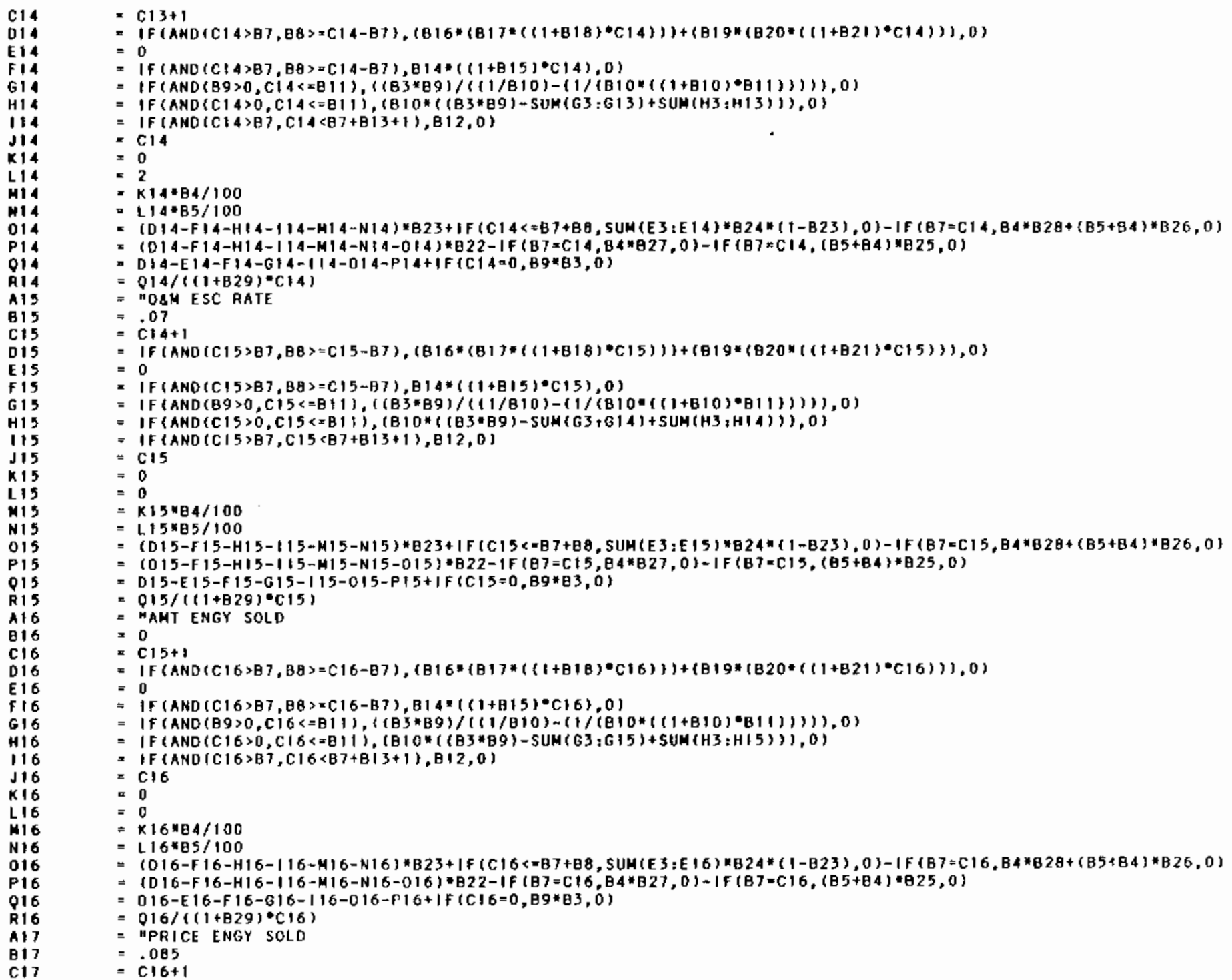


TABLE. B.2. contd

IF (AND $(C 17) B\}, B B)=C\{7-87),(B 16 *(B) 7 *(\{1+B(8) \cdot C 17)))+(B) 9 *(B 20 *((1+B 21) \cdot C 17))), 0)$

$=0$

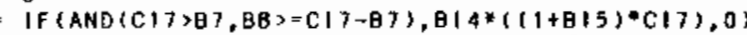

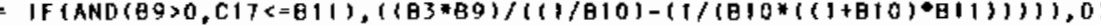

$=I F(A N D(C) 7>0, C 1)<=811\},(810 *((B) * B 9)-\operatorname{SUM}(G 3: G 16)+S U H(H 3: H 16)\}), 0)$

$=\{F(A N D(C, 17>B), C\{7<\theta 7+B 13+1\}, B 12,0)$

$=$ C17

$=0$

$=K 17 * B 4 / 100$

$=L 17 * B 5 / 100$

$=(017-F 17-H 17-117-M 17-A 17) * B 23+1 F(C 17 \times=B 7+B 8, \operatorname{SUM}(E 3: E 17) * B 24 *(1-B 25), 0)-I F(B)=C 17, B 4 * B 28+(B 5+B 4) * B 26,0)$

$=(017-F 17-H 17-117-M 17-N 17-017) * B 22-1 F(B 7=C 17, B 4 * B 27,0)-1 F(B 7=C 17,(B 5+B 4) * B 25,0)$

$=017-E 17-F 17-617-117-017-P 17+1 F(C 17=0,89=B 3,0)$

(1)

$=.08$

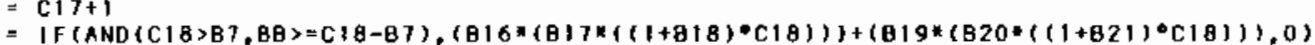

$=$ IF $(A N D\{C 18>B 7,88>=C(8-B 7), B 14 *(\{1+B 15) \cdot C 18), 0)$

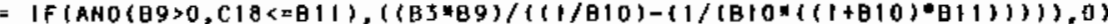

$=I F(A N U(C) 18>0, C 18<=B 1+),(B 10 *((B) * B 9)-S U M(G 3: G 17)+S U M(H 3: H: 7))), 0)$

$=\operatorname{IF}(A N D\{C 1 B>B), C 1 \theta<B 7+B 13+1\}, B(2,0)$

$=0$

$=0$

$=K 18 * B 4 / 100$

$L 18 * B 5 / 100$

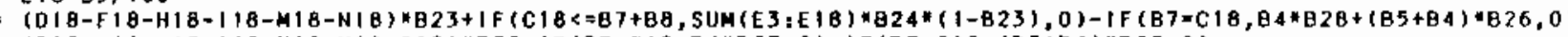
$=(018-F(8-H 18-118-M 18-N 18-018) * B 22-1 F(B 7=C 18, B A * B 27.0)-I F(B T=C 18,(B 5+B 4) * B 25,0)$

$018-E(8-F) 8-G(8-T 18-018-P 18+T F(C)=0, B 9 * B 3,0)$

CIAHT ENGY DISP

$=0$

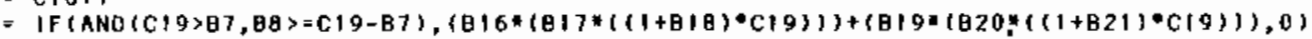

$=0$

$=$ IF (ANO $(C 19>\theta), 88)=C 19-B 7), B 14 *((1+815) \bullet C 19), 0)$

$=\operatorname{IF}(A N O(B 9>0, C(9<-B 11),((B) * B 9) /(\{1 / B 10)-(1 /(B) 0 *((1+B(0) * B(1))))), 0)$

$=\operatorname{IF}(A N D(C 19>0, C\{9<=B 11),(B 10 \times\{(B 3 * B 9\}-5 U M(G 3: G 18)+S U H(H 3: H 18)\}), 0)$

$=\mid F(A N O(C 19>\theta), C 19<\theta 7+\theta(3+1), B(2,0)$

$=\operatorname{Cr}$

$=0$

$=K 19 \times 84 / 100$

$=L 19 k B 5 / 100$

=

(D)

=

$=0$

$\left.=\mid F(A N D\{C 20>\theta), B B)=C 20-B 7),(B 16 *(B 1) *((1+B 18) * C 20)))+\left\{\theta+9 *\left(B 20 *\left((1+B 21){ }^{\circ} C 20\right\}\right\}\right), 0\right)$ 
TABLE B.2. contd

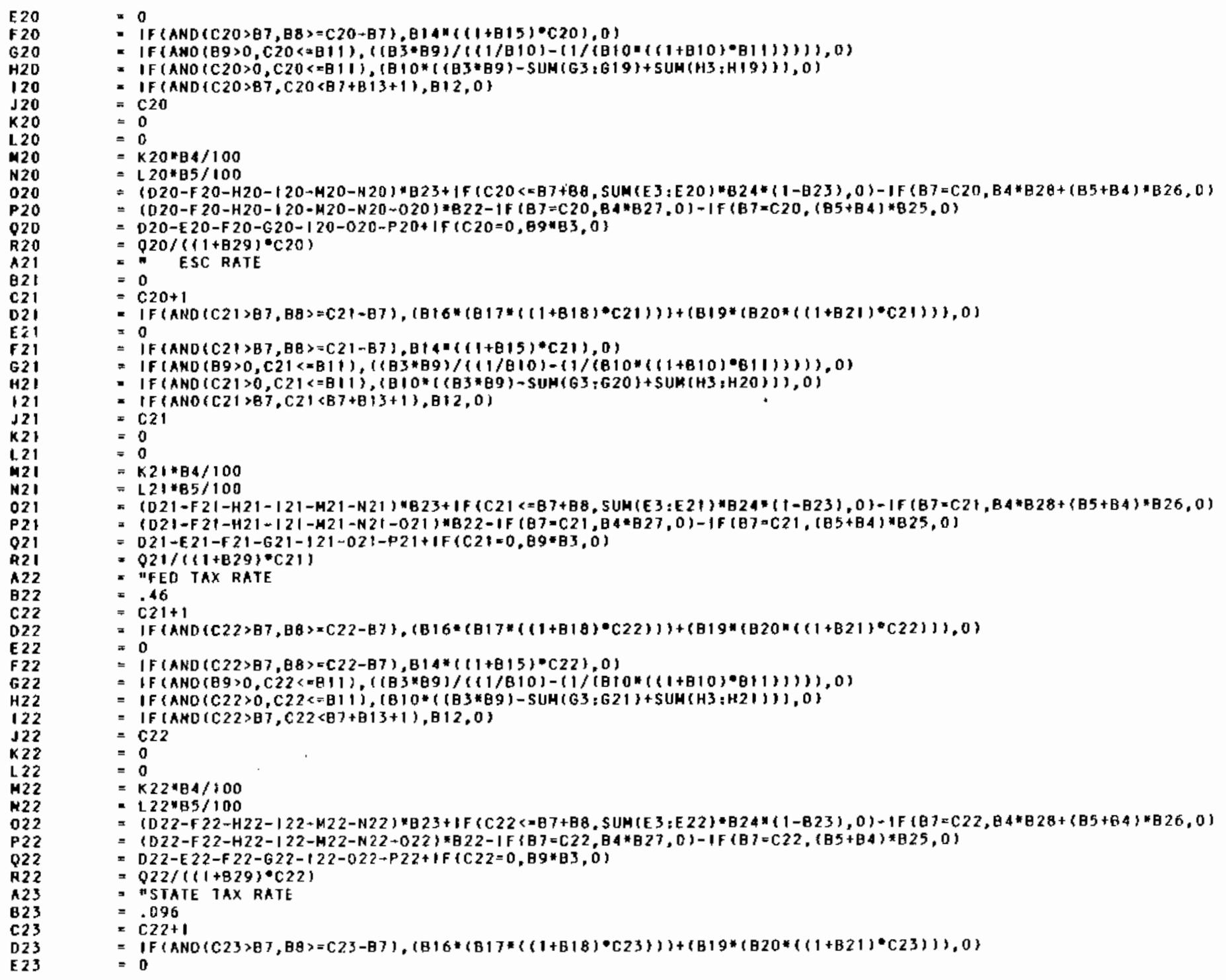


TABLE B.2. contd

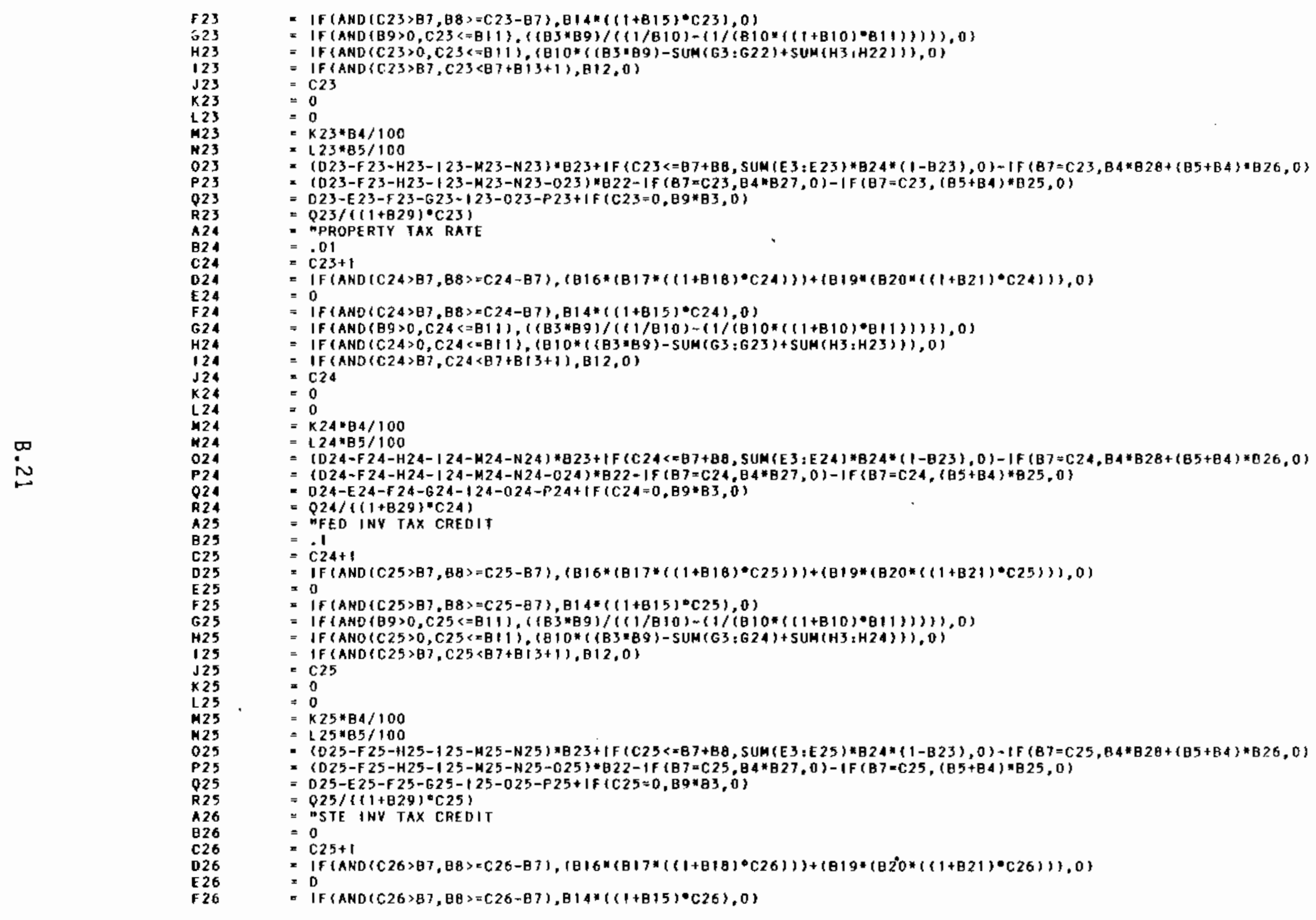




\section{TABLE B.2. contd}

$=I F(A N D(B)>0, C 26<-B 11),((B) * B 9) /((1) / B 10)-(1 /(B 10 *((1+B 10) * \theta 11))))), 0$

IF(AND $(C 26) 0, C 26<=B 11\},(B) 0 N(\{83=B 9)-S U M(G 3, G 25)+S U A(H 3: H 25)\}), 0)$

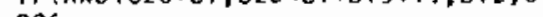

C26

$=0$
$=0$

$=\mathrm{K} 26 * \mathrm{~B} / 100$

$=126 * 85 / 100$

$=(D 26-F 26-H 26-126-\mathrm{M} 26-N 26) * B 23+I F(C 26<* B 7+B 8,5 U H(E 3: E 26) * B 2 * *(1-B 23), 0)-1 F(B)=C 26, B A * B 2 B+(85+B 4) * B 26,0)$

$=(D 26-\mathrm{F} 26-\mathrm{H} 26-126-\mathrm{H} 26-\mathrm{N} 26-026) * \mathrm{~B} 22-1 \mathrm{~F}(\mathrm{~B} 7=\mathrm{C} 26, \mathrm{~B} 4 * \mathrm{~B} 27,0)-1 \mathrm{~F}(\mathrm{~B} 7=\mathrm{C} 26,(\mathrm{~B} 5+\mathrm{B} 4) * \mathrm{~B} 25, \mathrm{O})$

D26-E 26-F 26-G26-|26-026-P26+IF (C26=0,89-B3,0\})

$=026 /((1+829) \cdot C 26)$

- "FED SOL tax CREOIt

$=.15$

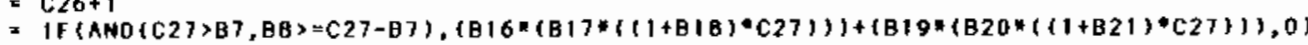

$=0$

$=$ IF(AND $(C 27>87, B B)=C 27-B 7), B 14 *((1+B 15) \cdot C 21), 0)$

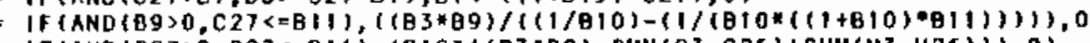

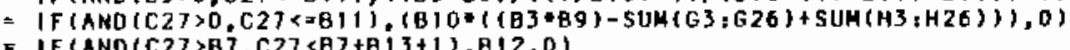

$=\mathrm{C} 2$
$=0$

$\begin{array}{ll}= & 0 \\ = & 0\end{array}$

$=\mathrm{K} 27 \cdot 84 / 100$

$=(027-F 27-H 27-127-H 27-N 27) * 823+1 F(C 27<* B++B 8, S U H(E 3, E 27) * B 24 *(1-B 23), 0)-1 *(B 7 * C 27, B 4 * B 28+(85+B 4) * B 26,0)$

$=(D 27-F 27-H 27-127-N 27-N 27-027)=B 22-\mid F(B)=C 27, B<N B 27,0)-1 F(B)=C 27,(B 5+B 4)=B 25,0)$

$=027-E 27-F 27-627-\{27-027-P 27+1 F(C 2]=0, B 9 * B 3,0)$

$=027 /((1+829) \cdot C 27)$

= "STE SOL TAX CREDIT

$=\dot{25}$

$=$ If $(A N O(C 28>B), B 8)=C 28-B)),(B 16 *(B 17 *((1+B(B) \bullet C 2 B)))+(B 19 *(B 20 *((1+B 21) \cdot C 28)\}), 0)$

$=0$

$=$ IF (AND $(C 28) B 7,8 B)=C 2 B-B 7), B(4 N((1+B 15) * C 28), 0)$

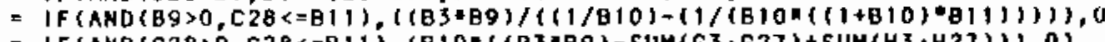

$=$ IF(ANO(C28) $20, C 28<=B 11),(B 10 *((B)=B 9)-S U M(G 3: G 27)+S U M(H 3: H 27) H, 0)$

$=$ I $F(A N D(C 2 B>B\}, C 28<B 7+B 1\}+1\}, B(2,0)$

$$
\begin{aligned}
& =\operatorname{Cr} 28 \\
& =0
\end{aligned}
$$

$=0$

$\approx \mathrm{K} 2 \theta * \mathrm{~B} 4 / 100$

- $128 * B 5 / 100$

$=(02 \theta-F 2 \theta-H 28-12 \theta-\mu 2 B-N 2 B-028) M B 22-1 F(B 7=C 2 B, B 4 * B 27,0)-1 F(B 7=C 2 B,(B 5+B 4) k B 25,0)$

$=02 \theta-E 2 \theta-F 2 B-62 B-12 \theta-02 B-P 2 \theta+18(C 2 B=0, B g=B 3.0)$

$=Q 28 /\left((1+B 29)^{\circ} \mathrm{C} 28\right)$

= "OISCOUNT RATE

$=.15$

= "TOTAL EFFECTIVE NPY

$=\operatorname{SUM}(A 3: R 2 B)$ 


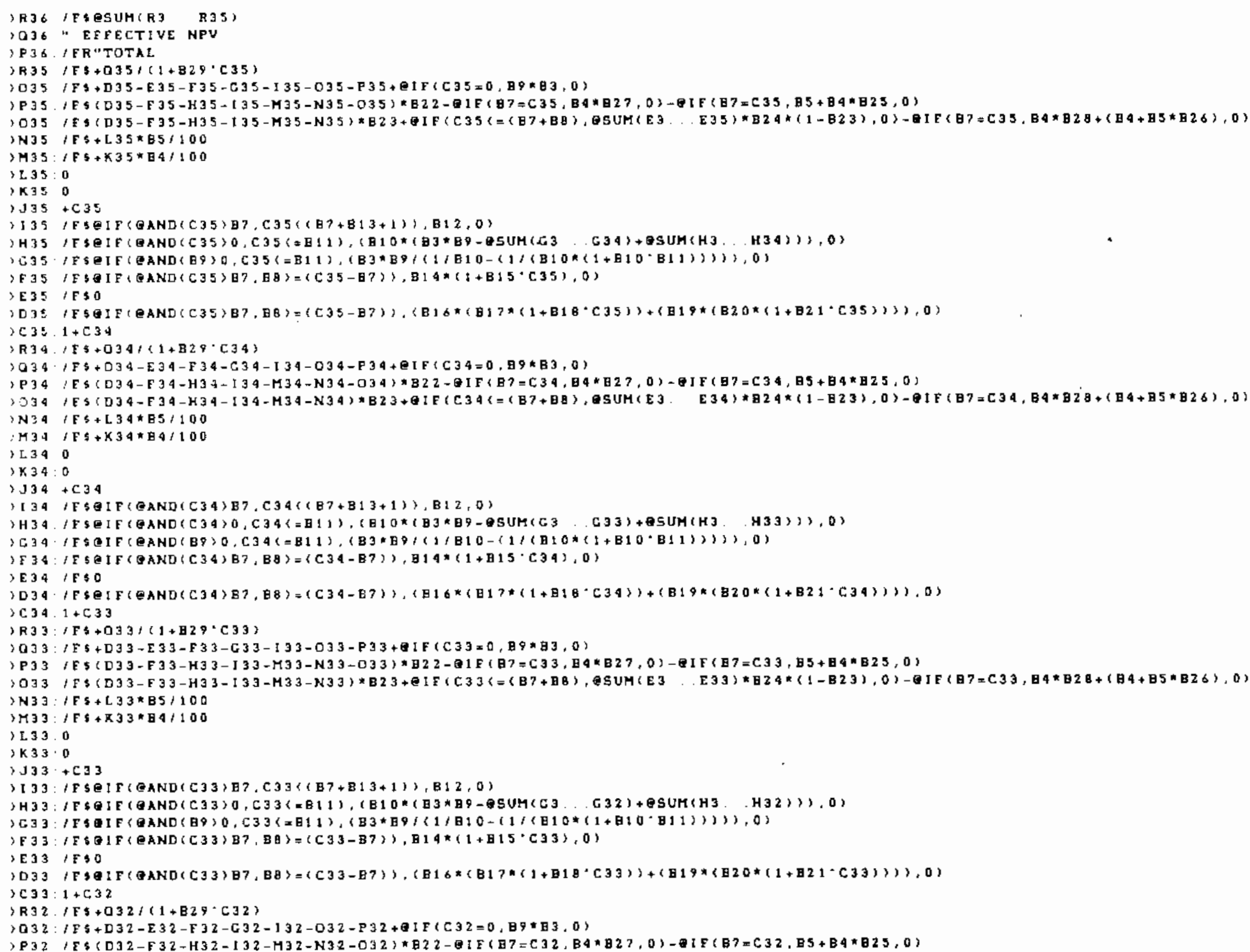


TABLE B.3. contd

\section{IN32: $/ F 9+\mathrm{L} 32 * E 5 / 100$}

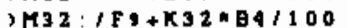

$3232: 0$

(र)

$1 \mathrm{J3}:+C 32$

II32, JFBEIF(OAND(C32) B , C32(CB $3+B 13+1)), 812,0)$

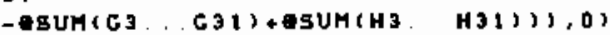

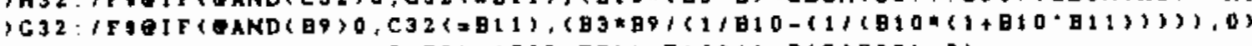

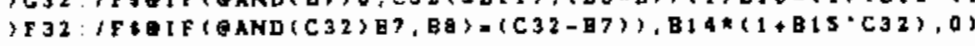

SE $32: 45: 0$

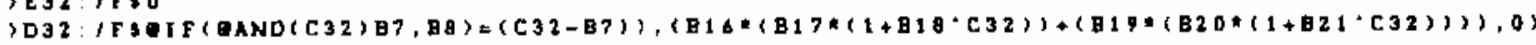

C $332 \cdot 1+C 3:$

3 R31: $/ F 3+031 /(1+829$ C 31$)$

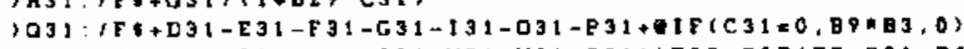

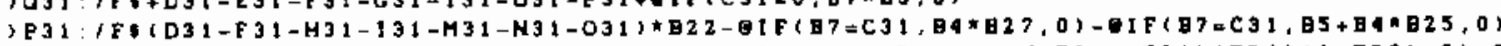

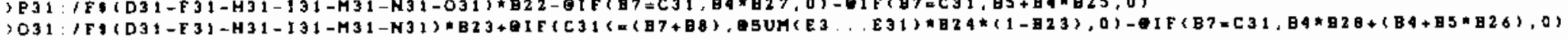

IN3 1: TFB+L31ABS/100

$>M 31: / F 5+X 31$ A $94 / 100$

$3 \mathbf{L} 31 \cdot 0$

I K31:0

$3 \mathrm{J3} 1:+\mathrm{C} 3 \mathrm{I}$

I 31 : TFAIE(OAND(C3))B $, C 3:((87+\theta 13+1)), B 12,0)$

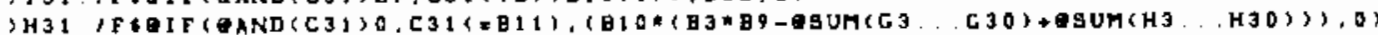

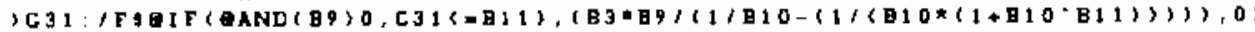

DO

ND31: IFGE

$>\mathrm{C} 31 \cdot 1+\mathrm{C} 30$

3 B $30 \cdot 1 \mathrm{CS}+0301(1+829 \cdot 030)$

$1030, \angle 5+D 30-E 30-F 30-630-130-030-P 30+\theta 1 F(C 30=0,09 * 83,0)$

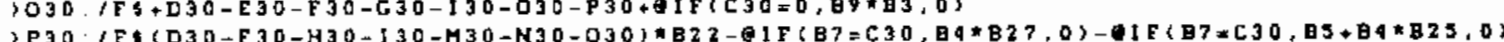

作

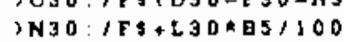

$3330=155+\times 30 * 341100$

$\longrightarrow \mathrm{L} 30 \cdot 0$

$>\mathrm{J}_{30}: 430$

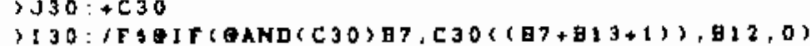

H 30 . IESE

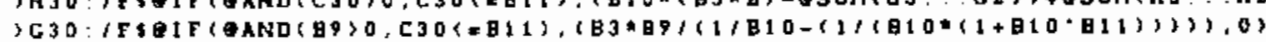

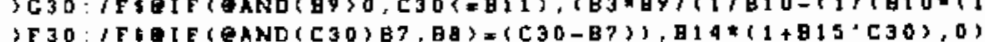

IE $30: 1 \mathrm{~F} 30$

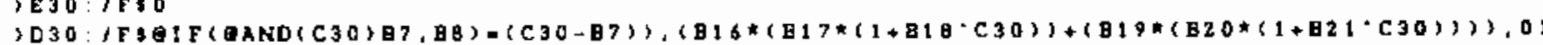

$>C 30: 1+C 29$

$>$ R $29 \cdot 153+0291(1+829 \cdot C 29)$

$1029: 1 F 6+D 29-E 29-F 29-C 29-129-029-P 29+Q I F(C 29 \times 0,89 \times B 3,0)$

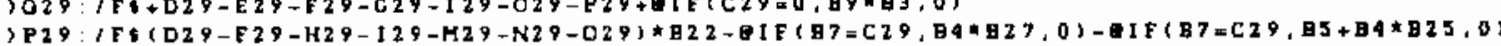

$>N 2 Q: I F B+L 29 \# B 5 / 100$

$>M 29: / 58+\pi 29 * 89 / 100$

$>1.29: 0$

$1 \times 29: 0$

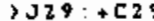

$3129 \cdot / F\{B I F(\theta A N D(C 29) B 7, C 29(\{B 7+B 13+1)), B 12,0)$

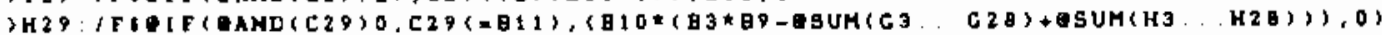




\section{IABLE B.3. contd}

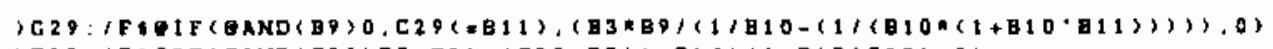

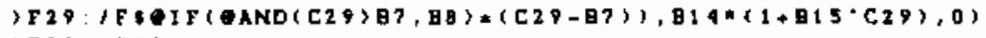

$3 E 5,1 E 50$

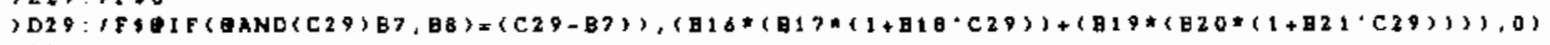

$3 \mathrm{C} 2: 1+C 28$

>B29:/ER.15

IA29: "DISCOUNT RATE

TR2 $B:(T B+O 2 \theta /(1+B 2 \theta-C 2 \theta)$

$302 B: C E B+D 2 B-E 2 B-E 2 B-C 28-I 2 B-02 B-P 2 B+B I F(C 2 B=0, B 9 * B 3,0)$

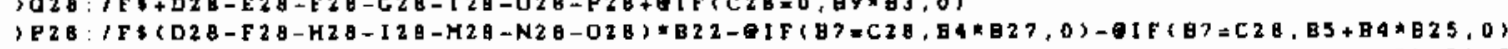

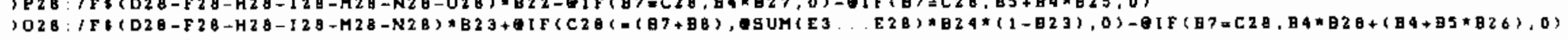

$3 N 2 B: / F \%+C, 2 \theta * 85 / 100$

IM2B: / FI+K2BNBA/100

$>\mathbf{L} 28: 0$

$3 K 28: 0$

J $32 B:+C 2 B$

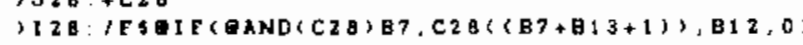

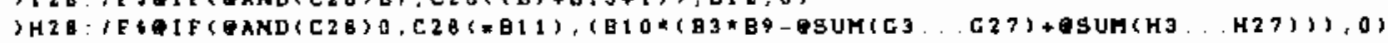

) G2B: IFBAIF(

SF $28: / F 3 A I F(A A N D(C 2 B) B 7, B \theta\}=(C 28-87)), B 14 A(1+B 15 \cdot C 2 B), 0)$

, E $2 \theta: / F \$ 0$

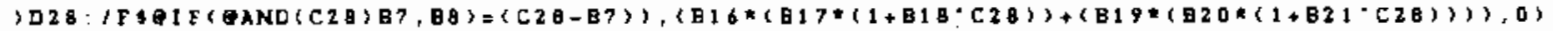

$1028: 1+C 2$ ?

D

N $\quad$ R2T: 1 F $2+027(1+B 29 \cdot C 27)$

G $\quad 3027: \angle F 3+D 27-E 27-E 27-C 27-127-027-P 27+Q 1 F(C 27=0, B 9 * B 3,0)$

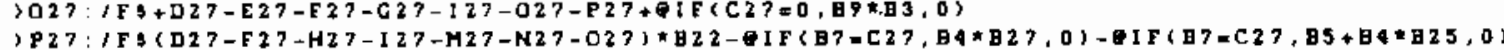

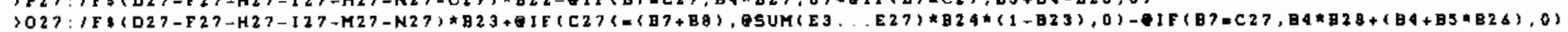

$3 N 27: 1 F:+27 * B 51100$

IM27: $1 F G+K 27 * 841100$

$327: 0$

$3 \times 27: 0$

$\mathrm{J} 27:+\mathrm{C} 27$

II27: /FUIF(OAND(C27) B7, C2)( $(\theta)+B 13+1)), \theta \pm 2,0)$

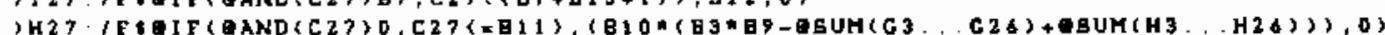

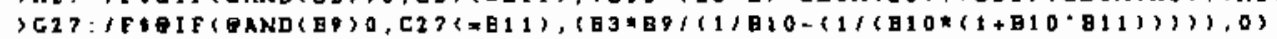

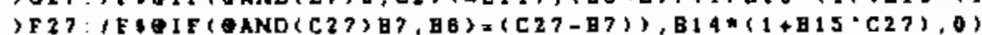

IE2 2: /F 0

(

$3 C 27: 1+C 26$

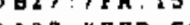

TA27: "TED SOL TAX CA

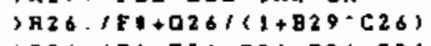

OQ26: $1 F 6+D 26-E 26-826-C 26-126-026-P 26+\theta 1 F(C 26=0, B 9 * B 3,0)$

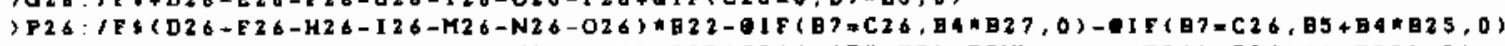

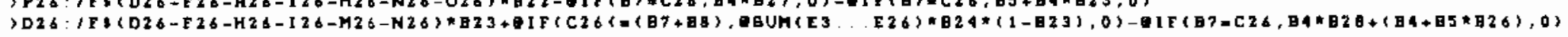

N N26: $/ F t+L 26 * B 5 / 100$

$3 M 26: / 59+K 26 * 84 / 100$

>2 $6: 0$

$2 \mathbf{K 2 6}: 0$

$1326:+C 26$

II 26 : F FAIF(OAND)(C26)B7,C26((B)+B13+1)), B12,0)

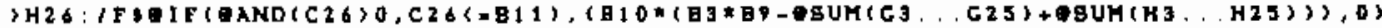

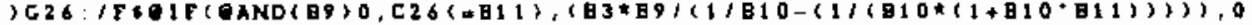


TABLE B. 3. contd

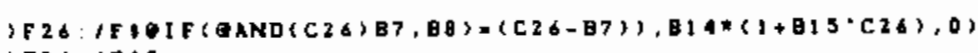

$>E 26: 1 \mathrm{~F}: 0$

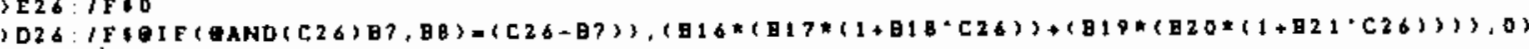

$>C 26: 1+C 25$

>B26: IFRO

A26: "STE INV TAX CA

$3 R 25 \cdot(E 4+025)(1+829 \times C 25)$

O25: $1 F 9+025-E 25-F 25-C 25-125-025-P 25+01 F(C 25-0, B Q 1 B 3,0)$

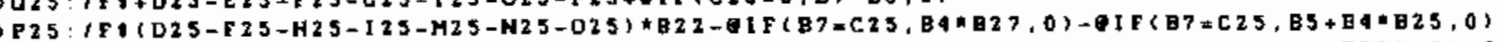

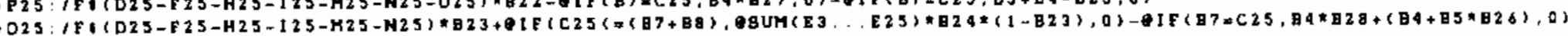

$3 N 25: / F 9+225 * 65 / 100$

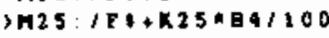

I2 25:0

IK25:0

$>325:+C 25$

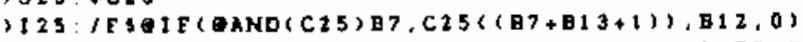

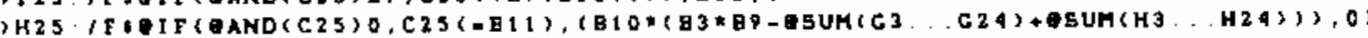

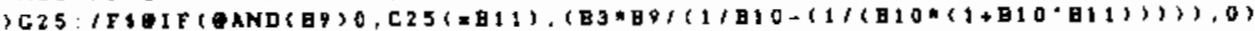

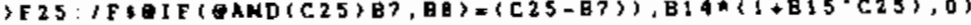

YE $25: 1 F 90$

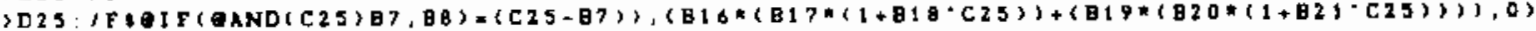

$3 C 25: 1+C 24$

$>$ B $25 \cdot$ T FR.

SA2S- "FED INV TAX CH

$3824 \cdot 183+024 /(1+B 29 \cdot C 24)$

OQ24: $1 F 5+D 24-E 24-F 24-G 24-I 24-024-F 24+Q 1 F(C 29=0, B 9 * B 3$, 0$)$

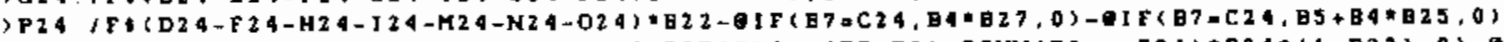

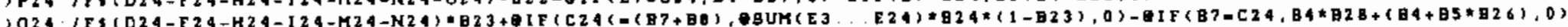

SN24 $1 F 3+L 24 * B 51100$

$2 M 24: / F 5+K 24 \times B 4 / 100$

3 L. 24:0 0

$324:+C 24$

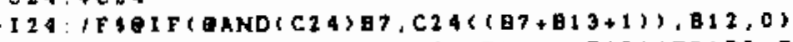

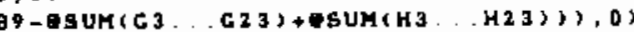

C 24 . (FB

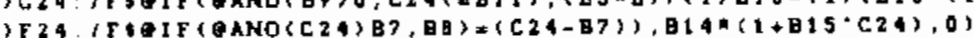

$>E 24.15 \% 0$

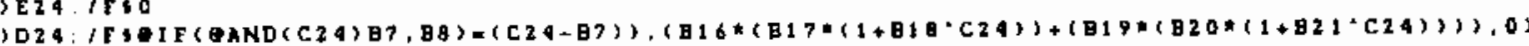

$1 \mathrm{C} 24: 1+\mathrm{C} 23$

B24: /FR. OI

AR2 : PROP TAX RATE

R23: $/ F+023 /(1+E 29 \cdot C 23$

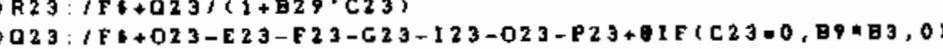

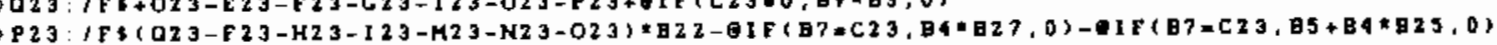

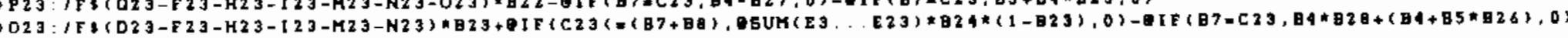

$>N 23: / E S+L 23 * 85 / 100$

$M 23: / F S+K 23 * B 91100$

, 2 23:0

$>\mathrm{K} 23: 0$
$\mathrm{~J} 23:+\mathrm{C} 23$

I 23 : IFIPIF(GAND $(C 23) 87, C 23(\{B 74-13+1)), B 12,0)$

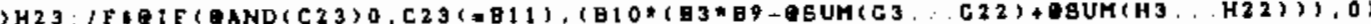

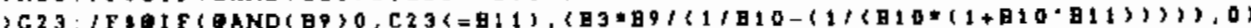

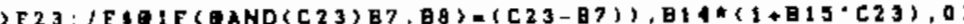




\section{TABLE B.3. contd}

, E23:15:0

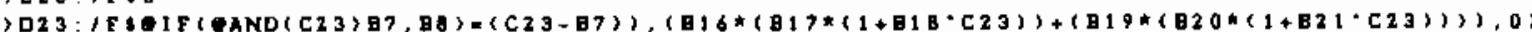

$>C 23: 1+C 22$

Q 23 : 1 F 096

SA3 " STATE TAX RATE

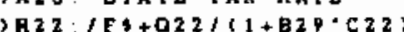

SO22: IF $3+D 22-E 22-F 22-G 22-I 22-022-P 22+0 I F(C 22=0, B 9 * B 3,0)$

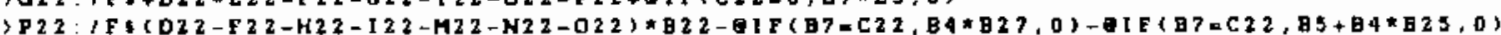

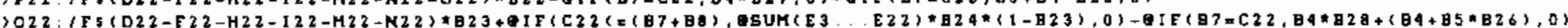
IN22: $\mathrm{F} \$+\mathrm{L} 22 \times \mathrm{BS} / 100$

$>1220$

$3 \times 22 \cdot 0$

$322:+C 22$

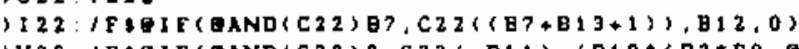

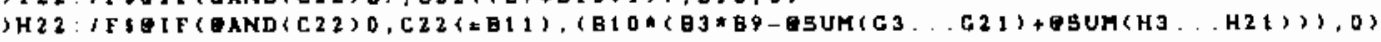

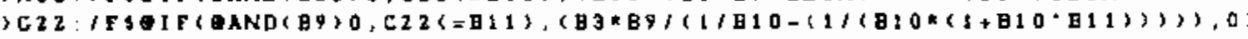

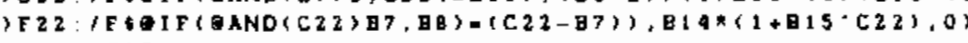

IE2 21530

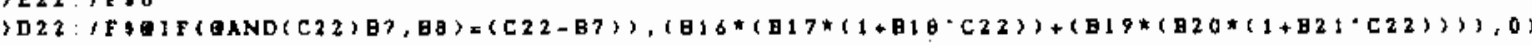

$>C 22: 1+C 21$

$3 \mathrm{B2} 2: 15 \mathrm{FA} \cdot 96$

TA2 2: "FED TAX RATE

) $221:(F)+021)(1+829 \cdot C 2 !)$

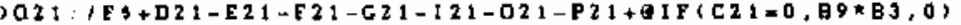

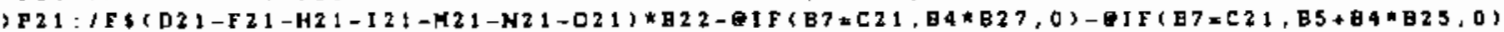

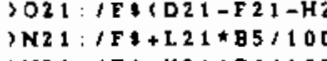

M21: $/ F C+K 21 * \theta 4 / 100$

I. $21: 0$

$, \mathrm{J} 21:+\mathrm{C} 21$

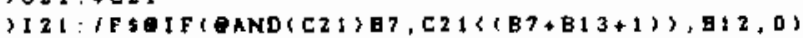

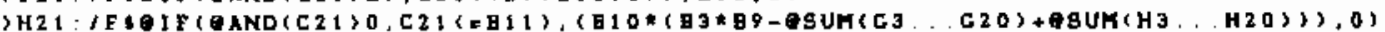

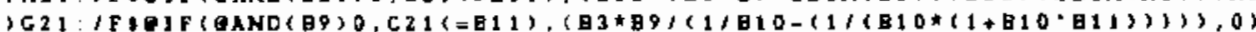

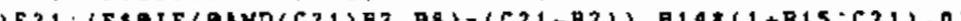

JE $21:$ TF:0

D21: IESTI

$\supset 221: 1+C 20$

OB2 $1: \angle \mathrm{FRO}$

TA21. MR"ESC RATE

तिO :

I2O-O2Q-P2O+QIE(C)2O=O,BS*E3,O

作

, 20 .

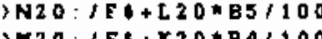

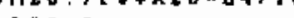

) $220: 0$

> $\mathbf{2} 20: 0$

$320:+C, 20$

\20: 253 IF

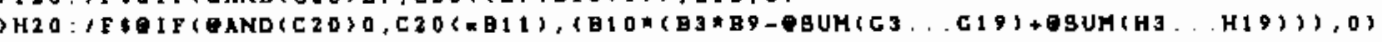

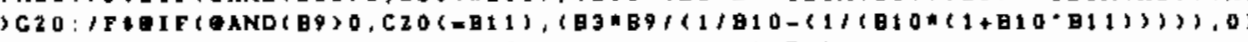

,E20: FFATE(OAND(C20)B\}, BB)=(C20-B)

\E20:15\%0 


\section{TABLE B.3. contd}

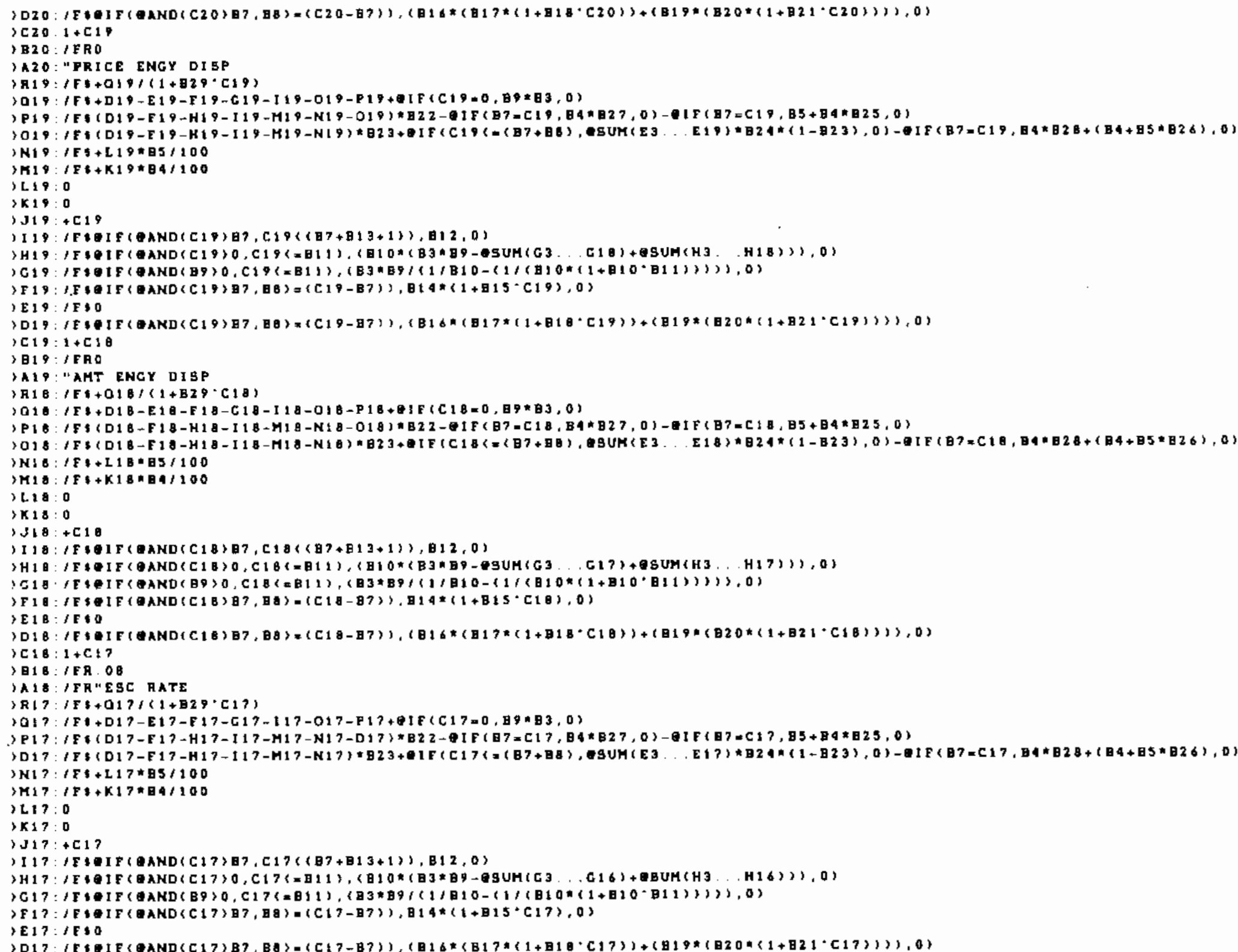




\section{TABLE B. 3 contd}

C17: $1+C 10$

B17: IFR. OA5

A17:"PRICE ENGY SOLD

SA16: $S F+016 /(1+B 29 \cdot C 16)$

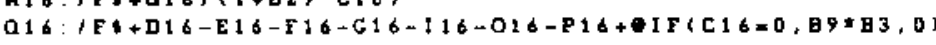

P16: /FA(D16-F16-H16-116-M16-N16-O16)*B22-OIF(B7*C16, B4*B27,0)-E1F(B7*C16,B5+B4*B25,0

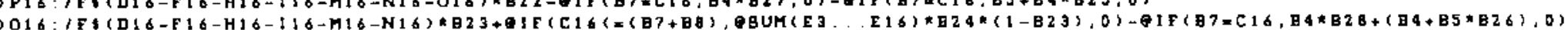

N16: /ES+L16OBS1100

K16:/Fi+K16BE4/100

$>\mathrm{L} 16 \cdot 0$

$3 \times 16 \cdot 0$

$>316:+C 16$

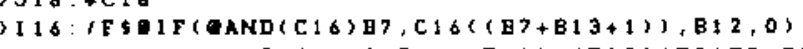

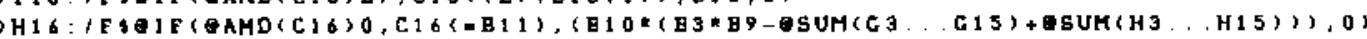

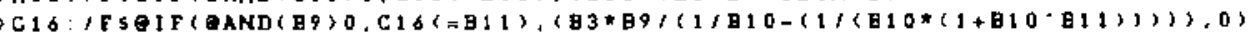

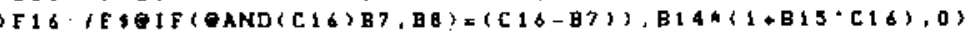

IE16: IF 30

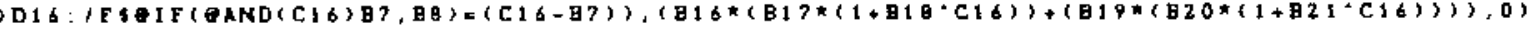

>C16.1 $1+$ C 15

>B16:1 FRO

A16: "AMT ENGY SOLD

R $15 / F 3+015(1+B 29 \cdot C 15)$

$>Q 15: / F \$+D 15-E 15-F 15-C 15-115-015-P 15+Q 1 F(C 15=0, \theta * B 3,0)$

P15:/Fi(D15-F15-H!5-I15-M15-N)

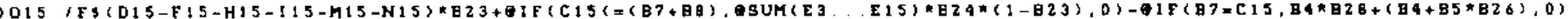




\section{TABLE B. 3 contd}

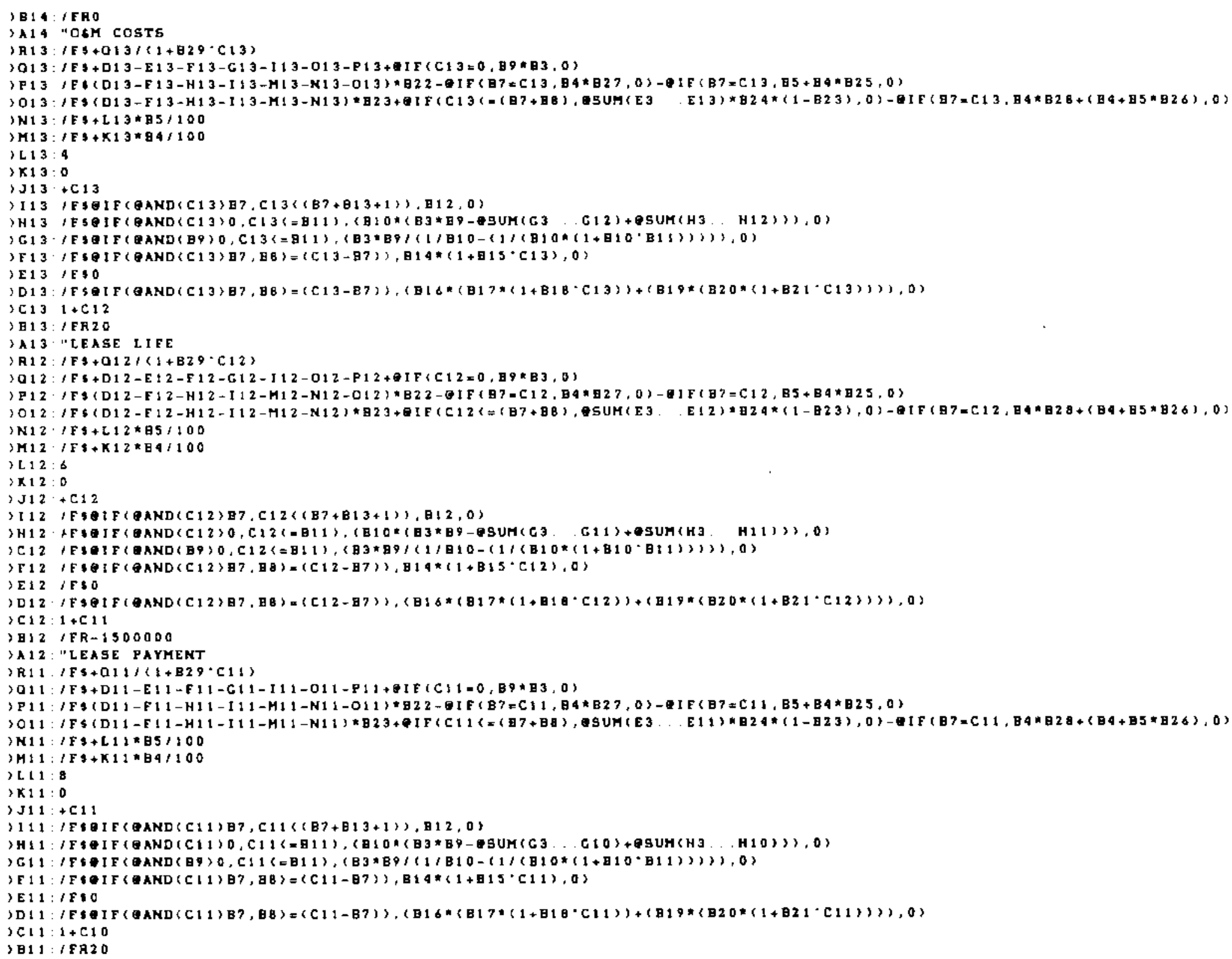


TABLE B. 3. contd

MALI: "LOAN LIEE

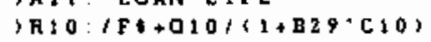

$3010.1 F 5+D 10-E 10-F 10-C 10-110-010-P 10+01 F(C 10=0, B 9 \times B 3,0)$

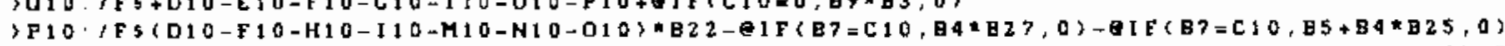

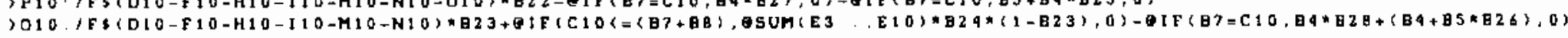

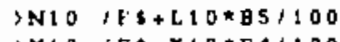

IM10.156+K1ONBA1100

$>\mathrm{L}: \mathrm{O}: 10$

$>$ K $10: 0$

J10: $+\mathrm{C} 10$

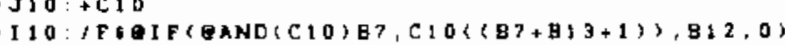

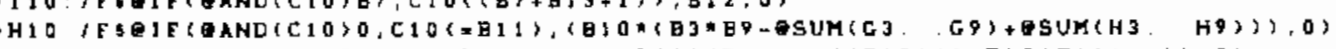

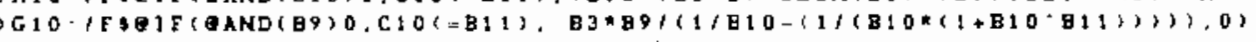

FIO TESEIF(OANO(C10)B?, BS) $($ (C10-B)) , B14*(1+B15-C10),

E $10: 18 \leqslant 0$

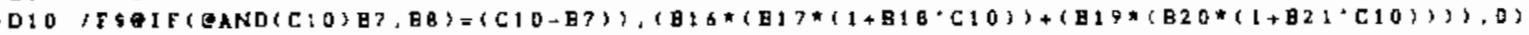

$>\cos 10: 1+c: 8$

3 B 10 : FR 15

AAD "LOAN INT RATE

RQ: 1 F $5+09 /(1+B 29 \cdot C 9)$

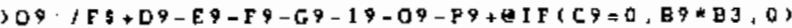

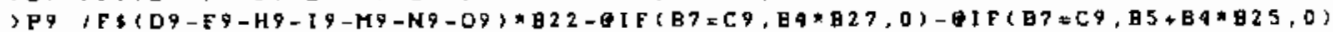

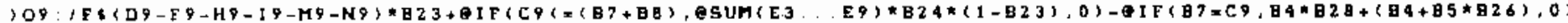

ING IES+L9*B5T100

$\omega_{\omega}^{\omega}$ $3 M 9 \cdot 1 \mathrm{~F} S+K 9 * B 41100$

$129: 12$

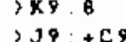

$239:+C 9$

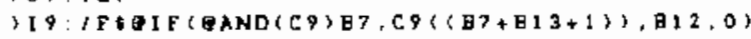

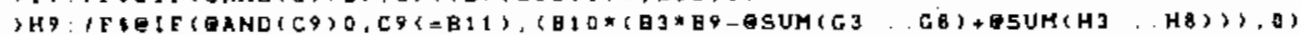

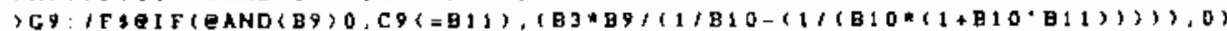

, $Q 9,1 E S G I F(O A N D(C 9) B ?, B \theta)=(C 9-87)), B 14 k(1+B 15 \cdot C 9), 0)$

IEQ: IF\$O

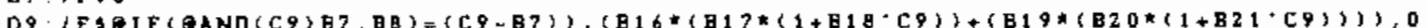

C $9: 1+C B$

ART DEGT FAACTION

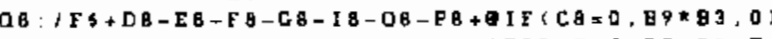

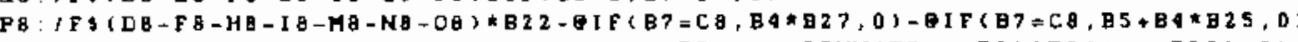

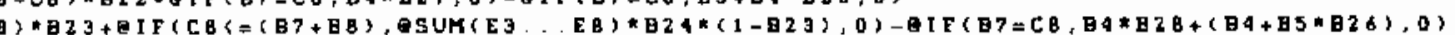

NB. $/ F \$+L 8 * B 5 / 100$

MB: $/ F s+X 8 * B 4 / 100$

>L 14

IK $\mathrm{K}: 16$

$\mathrm{JB}+\mathrm{C}$

I B : $/ 84 \theta I F(\theta A N D(C B) B\}, C B\{(B)+B) 3+1)), \theta 12,0)$

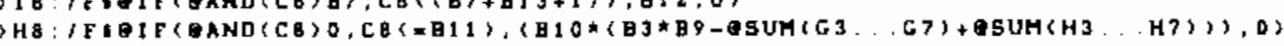

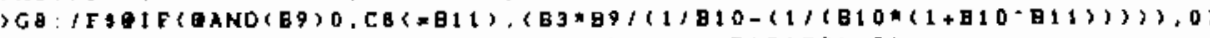

EB-/FSBIF(GAND(CB)B?, BB $=(C A-B 7)), B 14 *(1+B 15 \cdot C B), 0$

$>E Q: / F \$ O$

DB: IFs IF(OAND(CB)B,$B \theta)=(C B-B 7)),(B 16 *(B 17 *(1+B 1 B \cdot C B))+(B 19 *(B 20 *(1+B 2 ! \cdot C B))), 0$

$\therefore \mathrm{CB} \cdot \mathrm{i}+\mathrm{C} 7$

IBE: /F82O

YA8: "PLANT LIEE 


\section{TABLE B.3. contd}

IR7 $\quad \mathrm{F}+0 \mathrm{OO} /(1+\mathrm{B} 29 \cdot \mathrm{C} 7)$

>Q7: $185+D 7-E 7-E 7-C 7-17-07-P 7+8 I F(C 7=0, B 9 \times 83,0)$

(2)

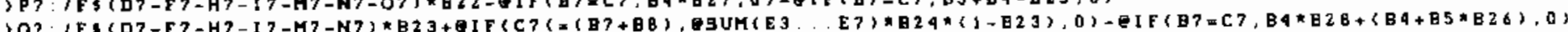

IN?: $1 \mathrm{FB+L7*85/100}$

\M7. $/ E S+K 7 * B 41100$

313.16

$3 \times 7 \quad 25$

$>37+C 7$

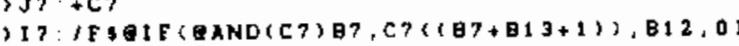

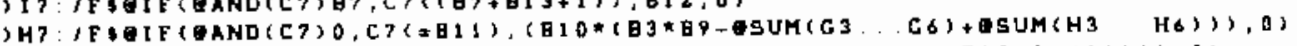

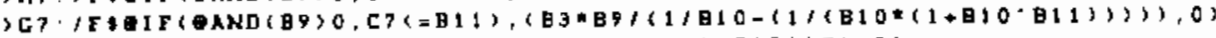

SE : /FSOIE (OANO(C7) B , BB) $\times(C ?-B 7)), 8144(1+815 \cdot C 7), 0)$

IE ?: /F 30

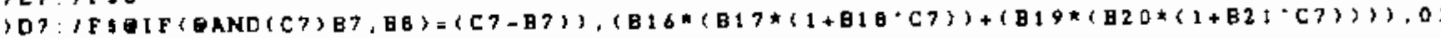

C $7: 1+C 6$

S В 7 : IF 2

IA7: "CONSTRUCT TIME

IR6: $1 \mathrm{~F} 3+08,(1+\mathrm{B} 29 \cdot \mathrm{C} 6)$

$306, I F \$+D 6-E 6-86-C 6-I 6-06-P 6+Q[F(C 6=0, B 9 * B 3,0)$

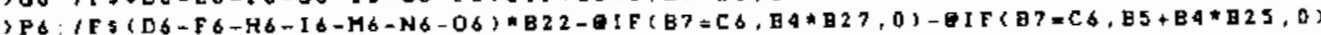

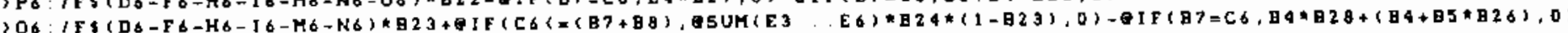

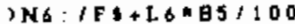

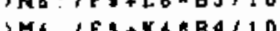

>L $6: 19$

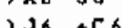

FseIFieAND(CS)B?,CS((B)+B) 3+1)), B12,0)

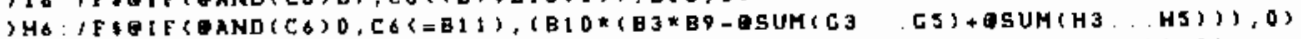

SG6. (E) IF(

J 6 , IFSEIF(EAND $(C 6) B 7, B B)=(C 6-B 7)), B 14 *(1+B 15 \cdot C 6), 0)$

SE6: 1550

(D6)

>C6: $1+C 5$

SB6. TER1200000

AA6 "LANO COST

RS: $1 \mathrm{~F}(+05 /(1+\mathrm{B} 29 \cdot \mathrm{C} 5)$

$305: I F 3+D 5-E 5-F 5-C 5-15-05-P S+B I F(C 5=0,89 * 03,0)$

B4*甘27,0)- Q1E(B7 $05,85+84 * \theta 25,0)$

$>05$ IFB(DS-F5-H5-15-M5-NS)*B23+EIF(C5)

SNS : $/ F S+L 5 * 651100$

$3 \mathrm{MS} \cdot \mathrm{IFS}+\mathrm{X} \times \mathrm{B} \times \mathrm{B} 4110 \mathrm{O}$

IL5: 9

IK5: 18

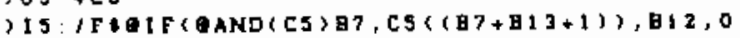

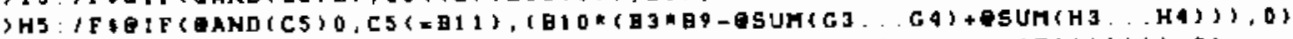

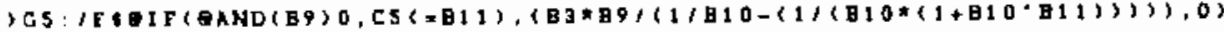

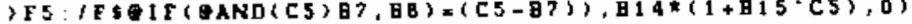

IES: IF\$29600000

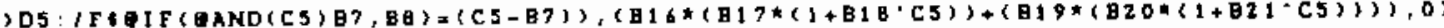

3 C $3: 1+C 4$

IAS: "NONSOLAR COST

, $\mathrm{AC}:(\mathrm{F}:+04)(1+B 29 \cdot(\mathrm{C})$ 


\section{TABLE B.3. contd}

$304: 1 F 5+C 4-E 4-F 4-G 4-I 4-O 4-P 4+Q T F(C 4=0, B Q * B 3, Q)$

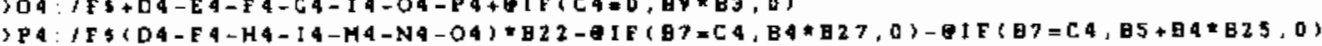

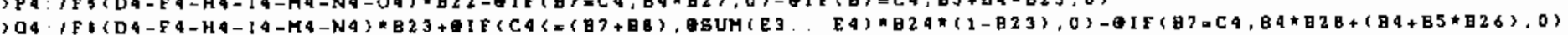

NA : IFS $+29 * B 51100$

SM4 $155+\mathrm{K}_{4} * \mathrm{~B} 41100$

IL : $: 0$

$3 \times 4: 0$

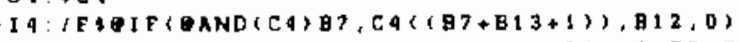

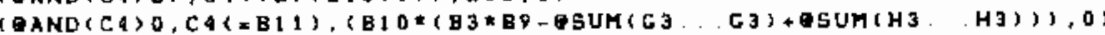

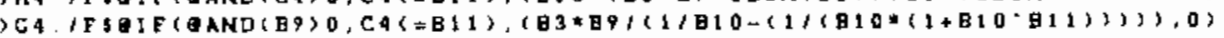

F : 1 E

EQ. TE\$29800000

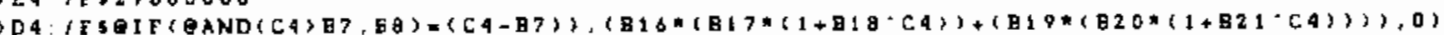

C $4: 1+C 3$

B4 1 F 557500000

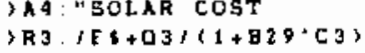

Q3 $\{F 3+D 3-E 3-F 3-C 3-13-03-P 3+915(C 3=0,89 n B 3,0)$

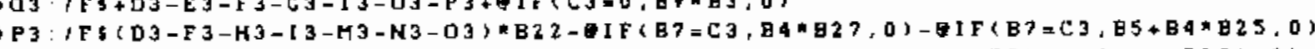

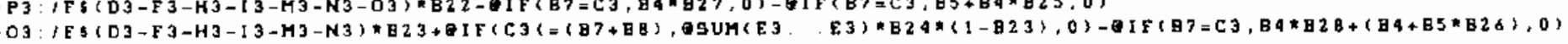

SN : $/ F:+[3 * B 5 / 100$

IM3: $/ F S+K 3 * B 4 / 100$

, L $3: 0$

$3 \mathrm{~K} \quad \mathrm{O}$

$>\mathrm{J}^{3} \rightarrow \mathrm{Cl}^{3}$

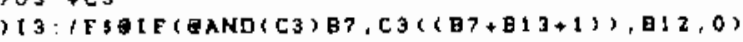

IH3: 1580

$, G 3: 16 \leqslant 0$

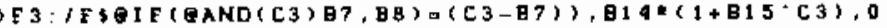

IE $3:$ : F $\$ 0$

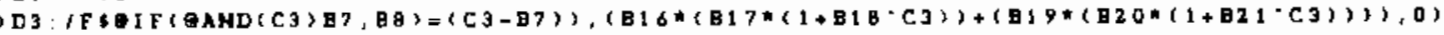

$>\mathrm{Cl}^{3}: 0$

SB 3 : IF 59400000

A3: "TOTAL PLANT CST

> $\mathrm{R} 2: t-*$

$\begin{array}{lll}>02 & l-* \\ \text { > P } 2 & 1-\star\end{array}$

$, 02: 1-{ }^{\prime}$

, $02: 1-*$

YN2: $1-n$

$\mathrm{M}^{2}: 1-*$

$3 \mathbf{2}: 1-*$

$3 \times 2: 1-*$

$32: 1-*$

$>15: 1-*$

H2:

गद2:1-

F $2 \cdot 1-\star$

पE $2: 1-$ *

D $2: 1-*$
C $2: 1-*$

उC2:1-*

>B2: 1 - *

IAZ: /

DOI IFR"NET CASH ELOL 
TABLE B.3. contd

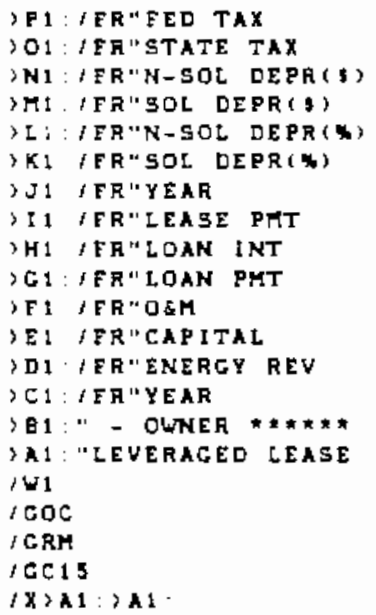


analysis of a specific case. Such modification was in fact required for the case studies presented in this report to get the model to appropriately simulate the sale-leaseback case for the plant user. For this case, the mode? was modified to allow sale of the plant after construction was completed, and to defer loan payments until the first year of plant operations. A sample display for the sale-leaseback plant user case is shown in Table B.4, with the cell output listing appearing in Tables B.5 and B.6 for the Supercalc and Visicalc versions. All other case studies in this report were generated with the model version documented in Table B.2. 
TABLE B.4. Mode] Display Format for Sale-Leaseback User Case

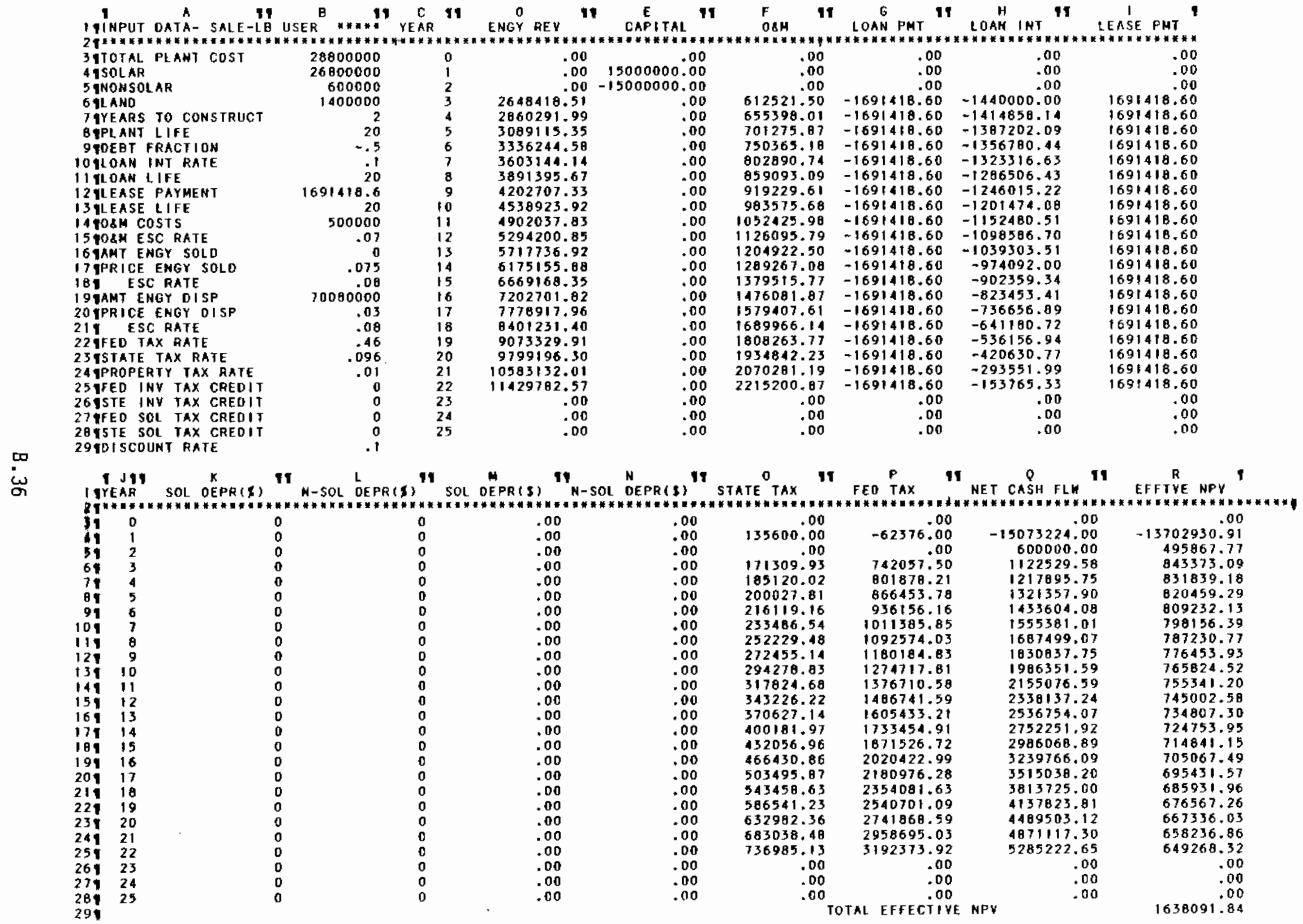


TABLE B.5. Mode1 Cell Contents for Sale-Leaseback User Case - Supercalc Version

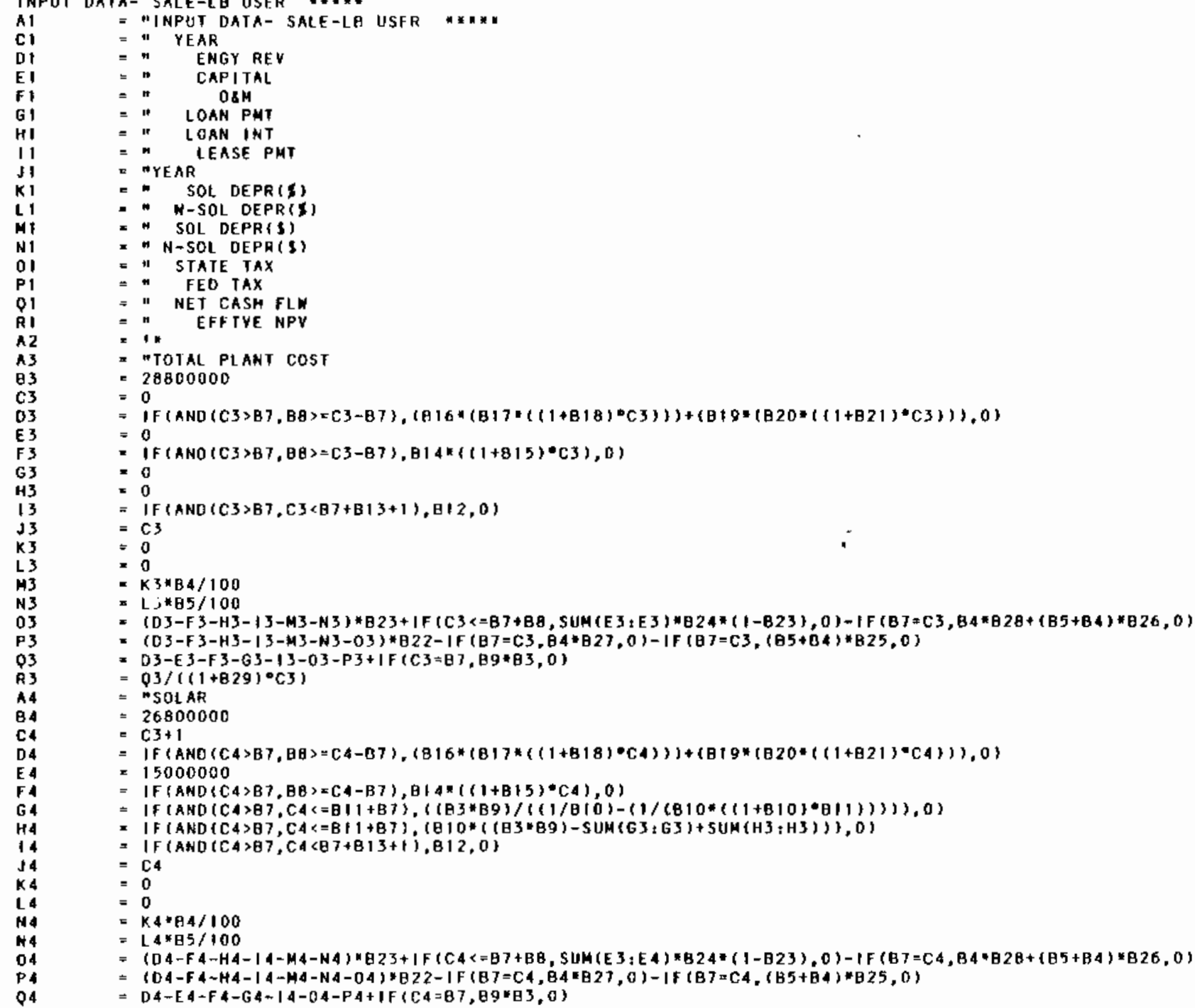


TABLE B.5. contd

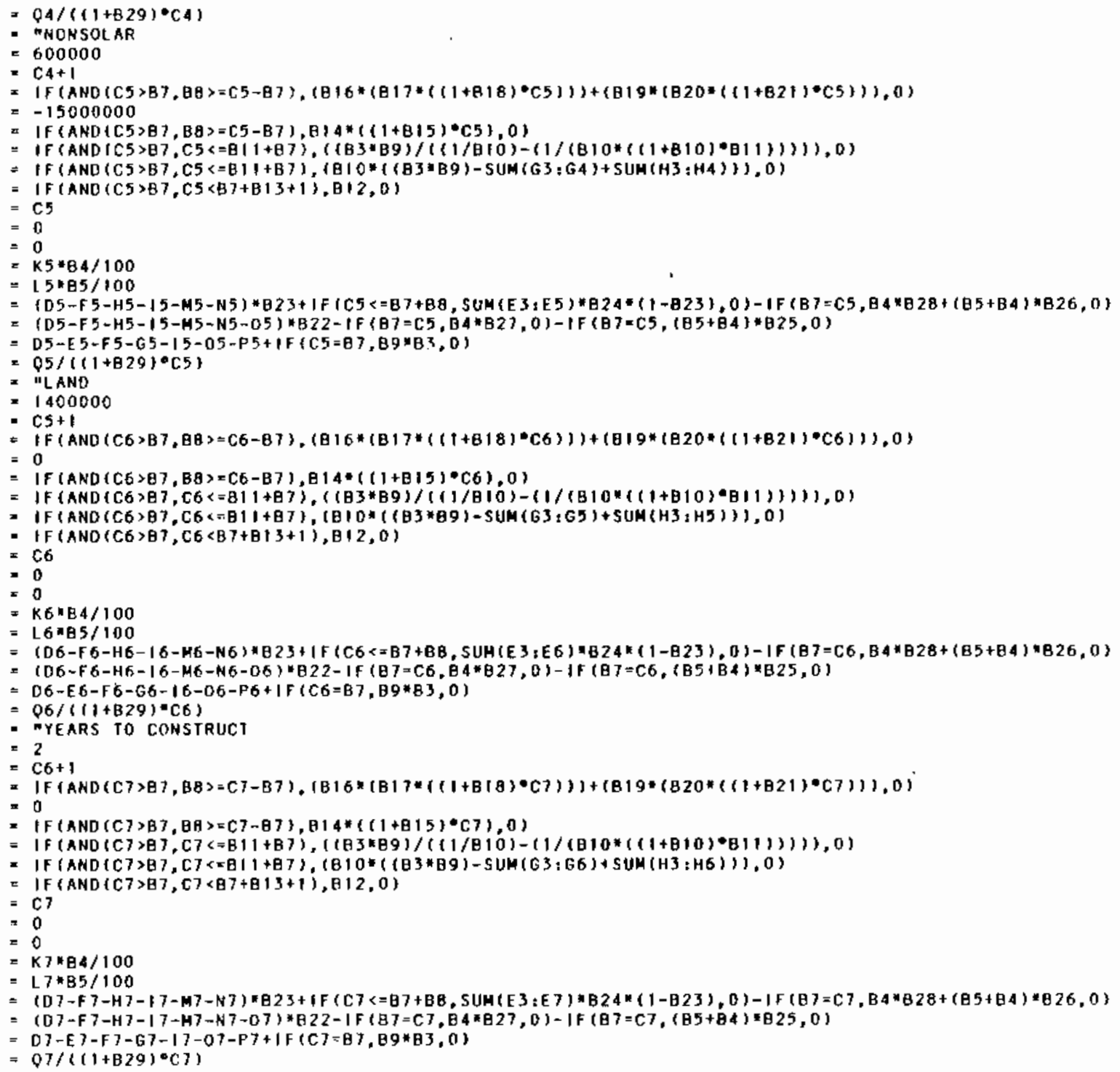


TABLE B.5. contd

$=" P L A N T$ LIFE

$=20$

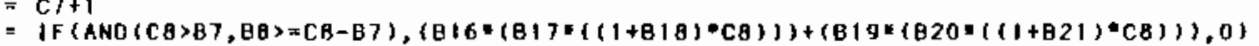

$=0$

$=$ IF (AND $(C 8>B 7, B 8)=C B-B 7), B 1 A *((1+B 15) \bullet C 8), 0)$

$=\mid F(A N O(C B) B 7, C \theta<x B(1+B 7),((B 3 * B 9) /((1 / B) 0)-(1 /(B) 0 \times((1+810)-B 11)\})), 0)$

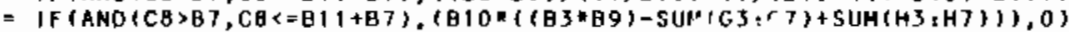

$=$ IF (AND C 8 : B $7, C 8<B 7+813+1), 812,0)$

$=\mathrm{CB}$

$=0$

$=K 8 * B 4 / 100$

$=18 * B 5 / 100$

$=(D \theta-F 8-H 8-18-M 8-N \theta) * B 23+I F(C B<=B 7+B \theta, \operatorname{SUM}(E 3, E B) * B 24 *(1-B 23), 0)+\mid F(B 7=C B, B 4 * B 28+(B 5+B 4) * B 26,0)$

$=(08-F B-H 8-18-M B+N B-08) * B 22-1 F(B 7 * C 8, B 4 * B 27,0)-1 F(B 7=C B,(B 5+B 4) * B 25,0)$

$=0 \theta-E 8-F \theta \sim G \theta-18-08-r \theta+1 F(C 8=B 7,89 * B 3,0)$

$=08$ (14tB2g)

$=-.5$

$=$ IF $\left.\left.\left.\left.(A N D(C 9) B 7, B \theta)=C 9-B),(B 16 *(B)]^{*}((1+B 18) \bullet C 9)\right\}\right)+(B) 9 *(B 20 *((1+B 21) \bullet C 9))\right), 0\right)$

$=0$

$=$ If $(A N D\{C 9>B 7, B \theta\rangle=C 9-B 7\}, B 14 *\{(1+B(5) * C 9), 0\}$

- IF (AND (C9)B,$C 9<=B 11+B 7),(183 * B 9) /((1 / B) 0)-(1 /(B 10 *((1+B 10) * B 11))\})\}, 0\}$

$=\operatorname{IF}\left(A N O(C 9>B 7, C 9<=B 11+B 7),\left(B ; 0^{*}((B 3 * B 9)-S U M(G 3: G B)+S U M(H 3: H B))\right), 0\right)$

$=\mid F(A N O(C 9) B), C 9<B 7+B+3+1), B 12,0$

$=C 9$

$=0$

$=$
$=$

$=19 * 85 / 100$

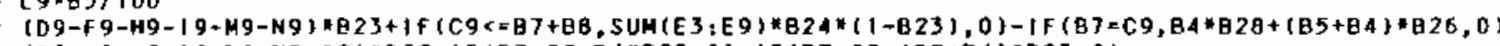

$=(09-F 9-H 9-19-H 9-N 9-09) * B 22-1 F(B 7=C 9, B 4 \times B 27,0)-I F(B 7=C 9,(B 5+B 4)+B 25,0)$

$=09-E 9-F 9-G 9-19-09-P 9+1 F(C 9-B 7,89 * B 3,0$

Q

$=0.1$

$\left.\left.=\mathrm{FF}(A N D(C 10) B), B 8)=C 10-B)\},\left(B 16^{*}(B) 7 *((1+B 18) \cdot C 10)\right)\right)+(B 19 *(B 20 *((1+B 21) \cdot C 10))), 0\right)$

$=0$

$=\mid F(A N O(C) 10>B T, B A)=C 10-87), B(4 *((1+B) 15) * C 10), 0)$

$=1 F(A N D(C 10) B 7, C 10<=811+87),((83 \times B 9) /(11 / 810)-(1 /(8) 0 \times((1+810) \cdot B 11)\})\}), 0)$

$=$ IF $\{A N D(C)>67, C 10<=B\{1+B\}),(B 10 *\{(B 3 * B 9)-5 U N(63, G 9)+S U H(H 3: H 9.1)\}, 0)$

$=I F(A)\{D(C 10>B 7, C 10<B 7+B 13+1), B+2,0)$

$=$ C10

$=0$
$=0$

$=K \$ 0.84 / 100$

$=\mathrm{L} 10 * \mathrm{~B} 5 / 100$

$=\{010-F(0-1110-110-H 10-N 10) * B 23+I F(C, 10<=B 7+B B, 5 U H(E, 3: E, 10) * B 24 *(1-D 23), 0)-1 F(B 7=C 10, B 4 \times B 28+\{B 5+E 4\} * B 26,0\}$

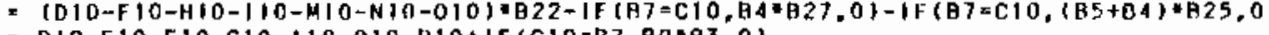

$=010 /\{(1+829) \times C 10\}$

- "LOAN LIFE 
TABLE B.5. contd

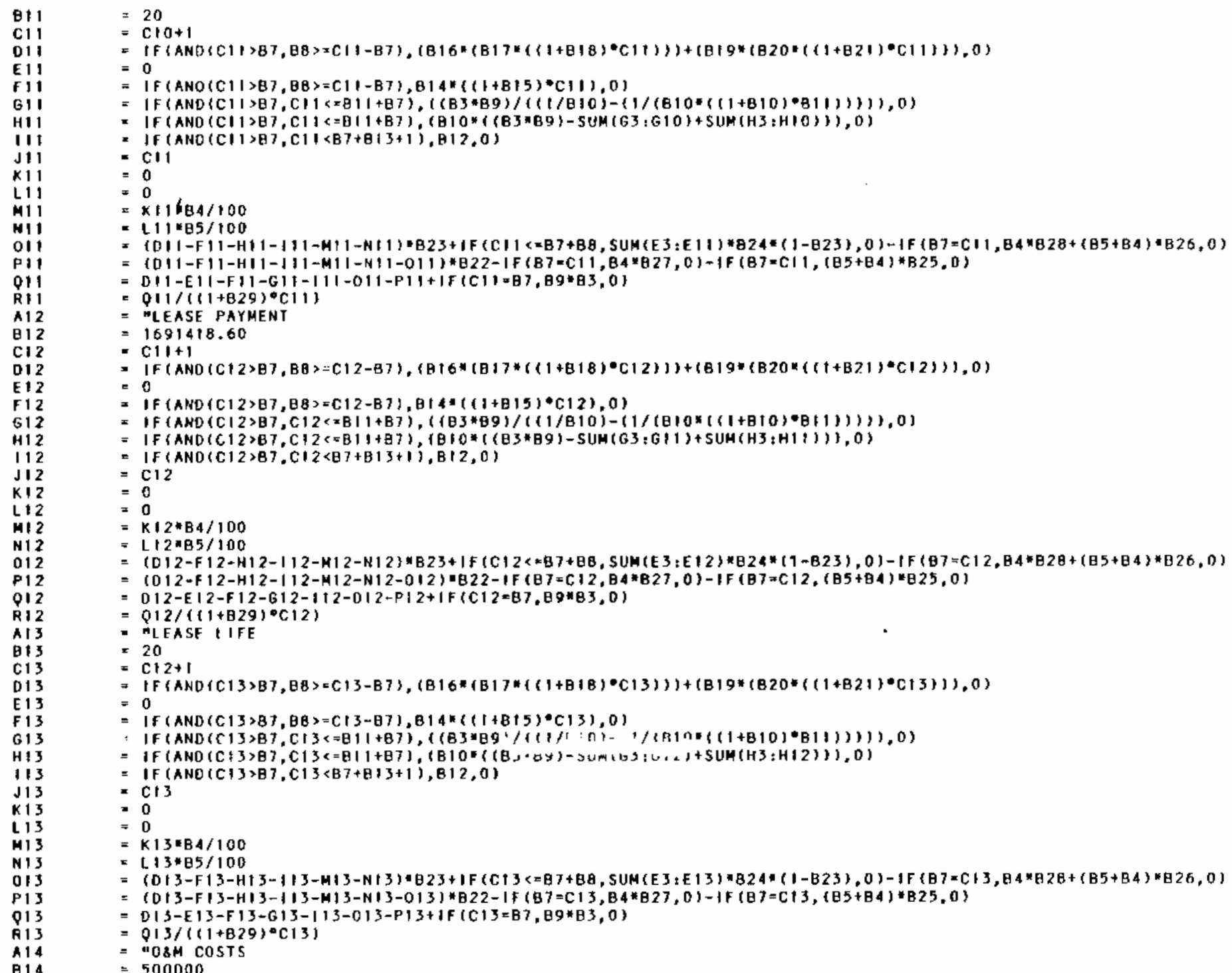


TABLE B.5.

contd

$\stackrel{\infty}{+}$

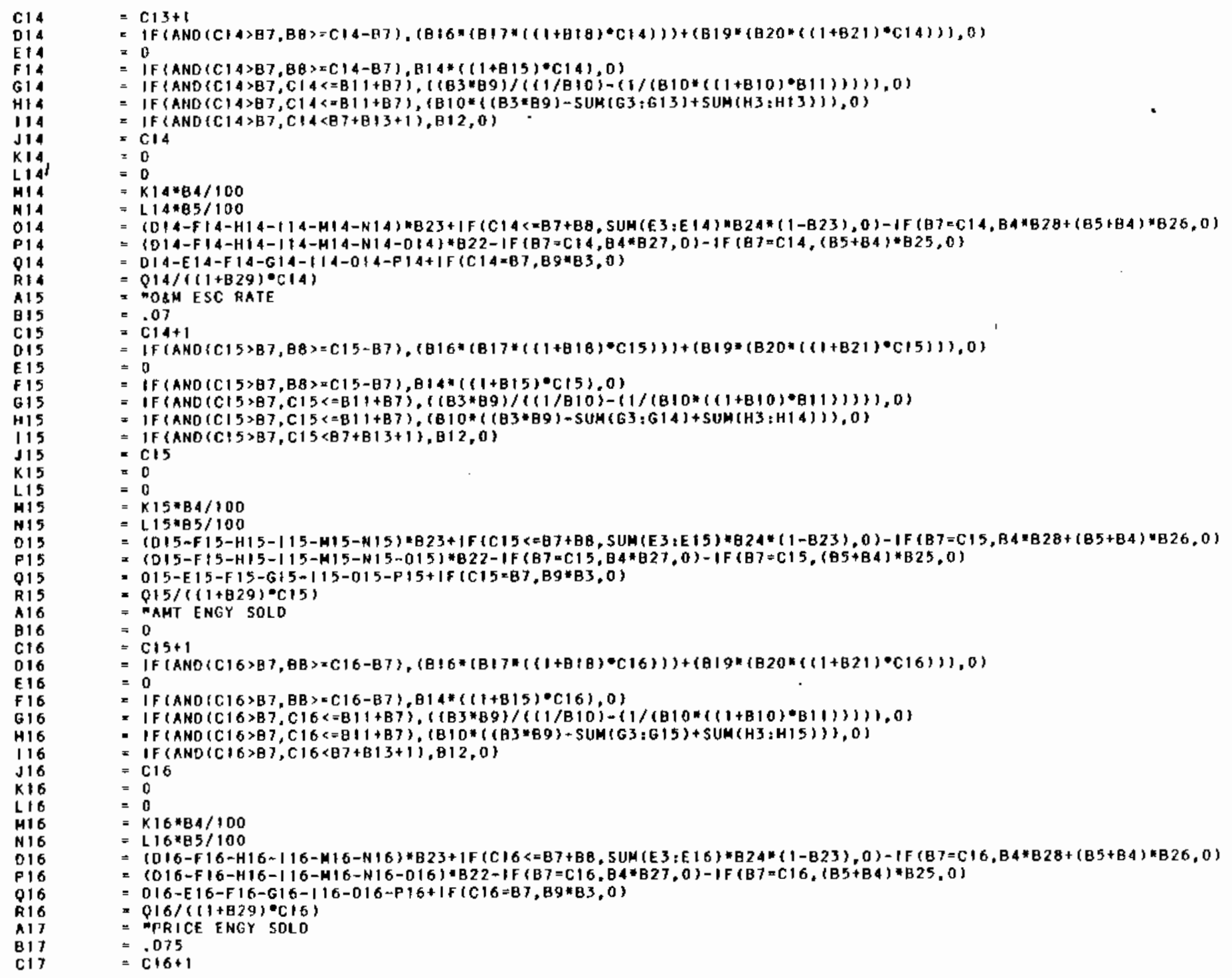


TABLE B.5. contd

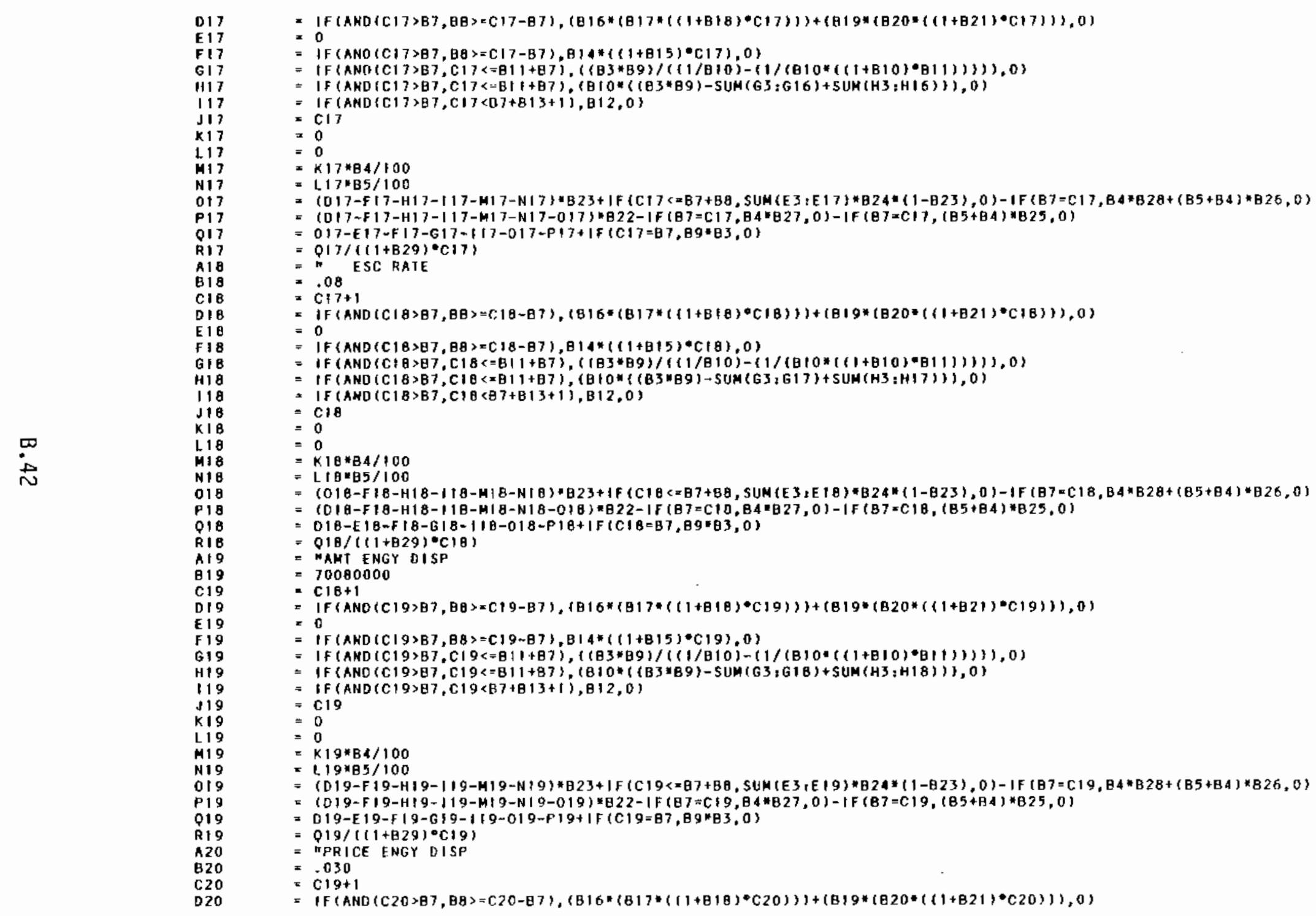


TABLE B.5. contd

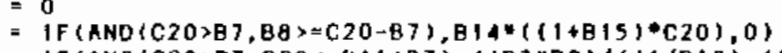

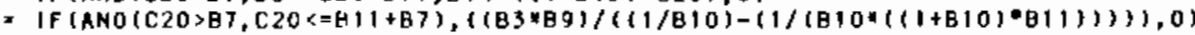

$=$ IF $(A N D<C 20>B), C 20<\times B) 11+B 7),\{B 10 *((B) * B 3)-\operatorname{SUM}(G 3: G 19)+\operatorname{SUM}(H 3: H 19)\}, 0)$

$=$ IF $(A N D(C 20>B 7, C 20<B 7+B 13+1), B(2,0)$

$=\mathrm{C} 20$

$\begin{aligned}= & 0 \\ = & 0\end{aligned}$

$=\mathrm{K} 20 * \mathrm{~B} 4 / 100$

$=\mathrm{L} 20 * \mathrm{BS} / 100$

$=(020-F 20-H 20-120-M 20-N 20) * B 23+\mid F(C 20<B)+B B, S U K(E 3 ; E 20) * B 24 *(1-B 23), 0)-I F(B)=C 20, B 4 * B 28+(B 5+B 4) * B 26,0)$

$=(D 20-F 20-H 20-120-\mu 20-N 20-020\} * B 22-1 F(B)=C 20, B 4 * B 27,0)-1 F(B 7=C 20,(B 5+B 4) * B 25,0)$

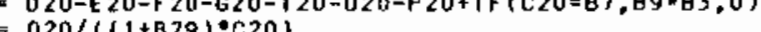

- ESC RATE

$=0$,

$=$ IF (AND $(C 21) B\}, B B)=C 21-B),(B) *(B)=((1+B) B) * C 21)))+(B 19 *(B 20 *((1+B 21) * C 21)), 0)$

$=0$

$=$ IF (AND (C21)B, 88$)=C 21-B)), 814 *((1+B 15) \bullet C 21), 0)$

$=$ IF $(A N D(C 21) B 7, C 21<* B 11+B 7),(\{B\} * B 9) /((1 / B 10)-(1 /(B) 0 *((1+B) 0) * B(1)\}))), 0)$

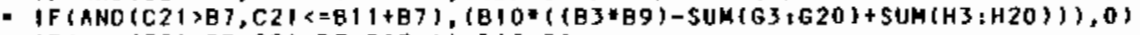

$=\operatorname{IF}(A N O(C 21) B\}, C 21<B 7+B) 3+1), B 12,0)$

$=\mathrm{C} 21$

$=0$

$=\mathrm{K} 21 * \mathrm{~B} 4 / 100$

$=121 * 85 / 100$

-

$=(D 21-F 21-H 21-121-M 21-N 21-021) * B 22-1 F(B 7=C 21, B 4 * 827,0)-B F(B)=C 21,(B 5+B 4) * B 25,0$

$=021 /((1+829) \circ \mathrm{C} 21)$

F "FED TAX RATE

$=.46$

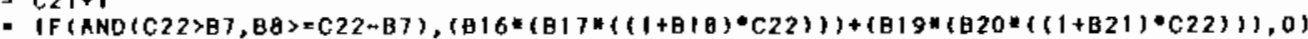

$=$ IF $\left\{\right.$ AND $\left.\{C 22>87, B \theta>=C 22-B 7\}, B 14 *\left(\{1+B 15)^{\circ} \mathrm{C} 22\right\}, 0\right\}$

$=$ IF $\left.\left.(A N D(C 22) B 7, C 22<=B 1)+B 7),\left((B 3 * B 9) /\left((1 / B 10)-\left(1 /(B) 0^{*}((1+B 10) \cdot B 11)\right)\right)\right)\right), 0\right)$

$=$ IF $(A N O(C 22>B 7, C 22<B B 11+B 7),\{B 10 N((B)=B 9)-\operatorname{SUH}(G 3: 621)+S U M(H 3: H 21))), 0)$

$=\operatorname{IF}(A N D(C 22>\theta), C 22 \times B 7+B+3+1), B(2,0)$

$=\mathrm{C} 22$

$=0$

$=0$

$=\times 22 * 84 / 100$

$=\mathrm{L22*85/100}$

= $(022-F 22-H 22-122-H 22-N 22) * B 23+\mid F(C 22<-B 7+B 8$, SUH $(E 3: E 22) * B 24 *(1-B 23), 0)-(F(B)=C 22, B 4 * B 2 B+(B 5+B 4) * B 26,0)$

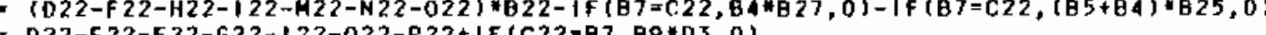

D220210

$=$ "STATE TAX RATE

$=.096$

$=\dot{c} 22+1$

$=\mid F(A N B(C 23) B 7, B \theta)=C 23-B 7),(B 16 *(B) 7 *((1+B) \theta) \cdot C 23)))+(B 19 *(B 20 *(11+B 21) \cdot C 23)) 1,0\}$

$=0$ 
TABLE B.5. contd

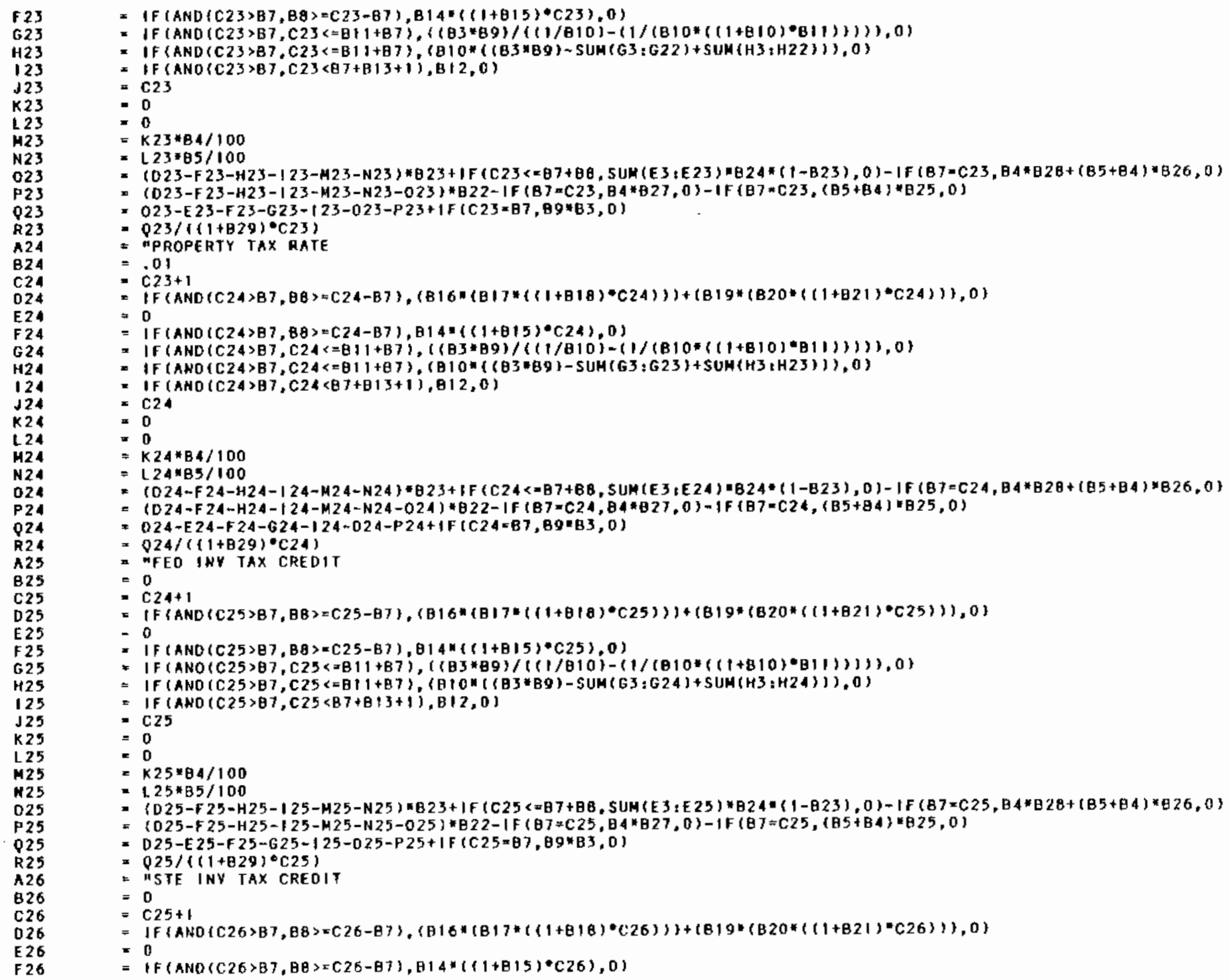


TABLE B.5. contd

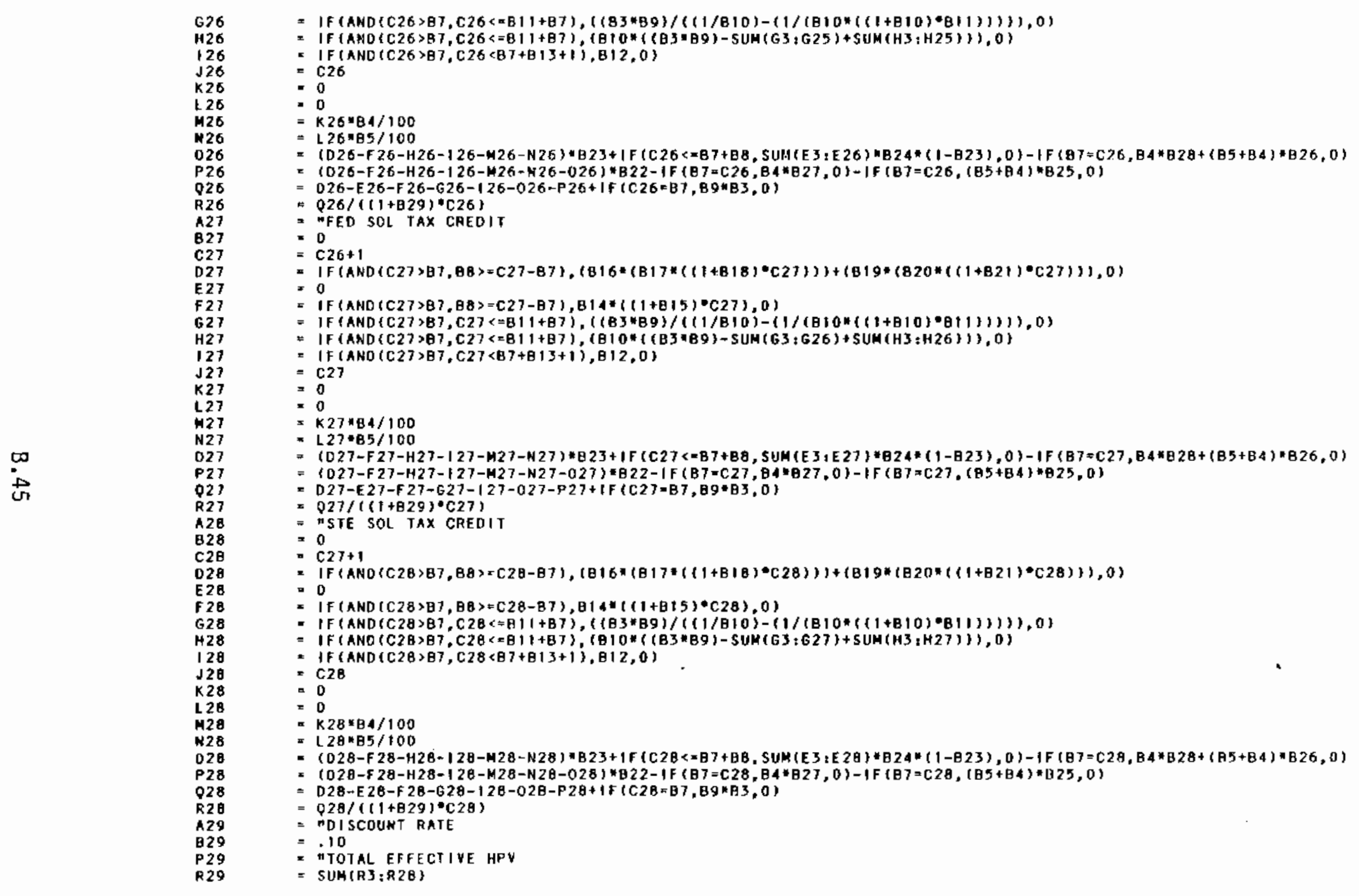


TABLE. B.6. Model Cell Contents for Sale-Leaseback User Case - Visicalc Version

IA $42:$ IFS

YA4 : IES

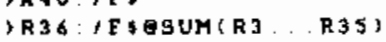

OB6 : EFFECTIVE NPV

P96: / $F$ R"TOTAL

) $935: / 65+035 /(1+829 \cdot \mathrm{C} 35)$

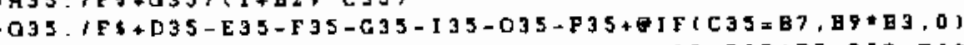

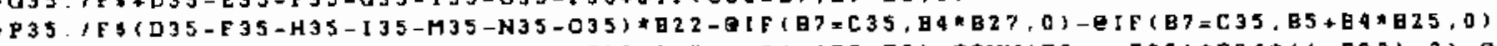

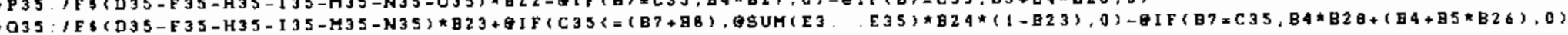

$3 N 35: / F 5+135 * 85 / 100$

$3 \mathrm{MBS} \cdot / \mathrm{F} 3+\mathrm{K3} 3 * \mathrm{BA} / 100$

IL 350

$335 \cdot 0$

$>\mathrm{J} 35:+\mathrm{C} 35$

I3S TFSOIF(OAND(C35)B7, C35(2B7+B13+1\}),B\}2,0)

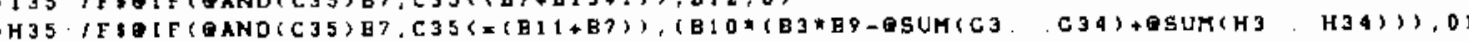

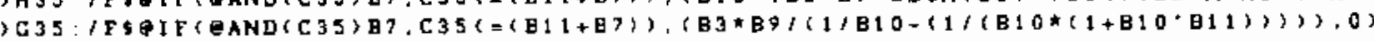

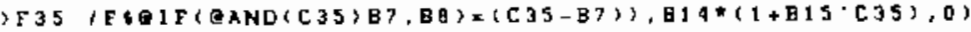

IESS: IFSO

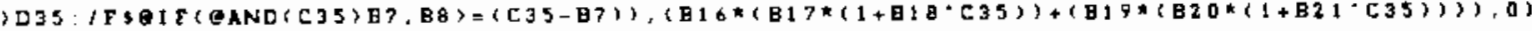

, $\mathrm{C} 35.1+\mathrm{C} 34$

$3834 \cdot(F 5+039 /(1+829 \cdot C 39)$

OQ34: IF $3+034-E 34-F 34-G 34-139-034-P 34+E ! E(C 34=87, B 9 * B 3,0)$

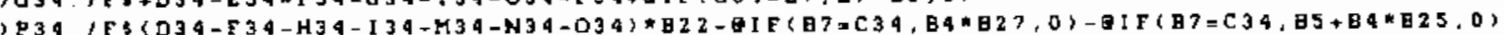

$\infty$

(2)

INBS: $/ F S+L 34 * B S 1100$

$3 M 34$ IES $+K 34 * B 4 / 100$

31340

$334+\mathrm{C} 34$

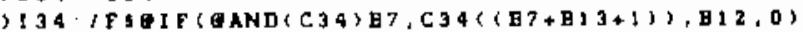

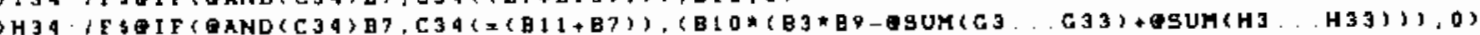

C34. F3EIF(

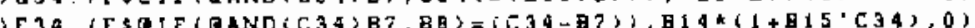

SE $39: / F \leqslant 0$

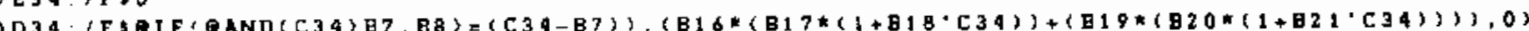

$>\mathrm{C} 39 \cdot 1+\mathrm{C} 33$

R33 $183+033 /(1+829 \cdot \mathrm{C} 33)$

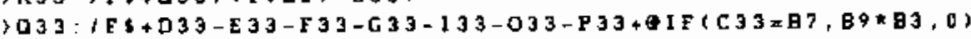

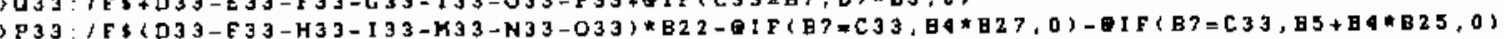

(

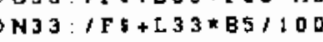

$, M 33: / F 3+K 33 * B 4 / 100$

$>133.0$

$2 \mathrm{K3} 3 \mathrm{O}$

$\mathrm{J} 33: \rightarrow \mathrm{C}_{3}$

I 33 , TSB IE $\{$ AND $\{C 33) B ?, C 33(\{87+B 13+1)\}, B 12,0)$

H 33 : IESGIF(

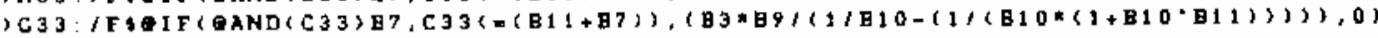

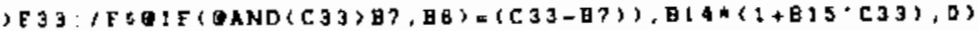

3 E.3 $: / F \div 0$

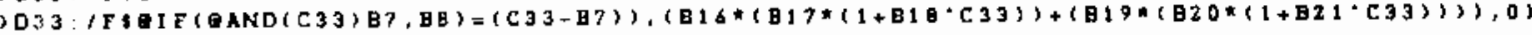

) C $33: 1+\mathrm{C}_{3} 2$

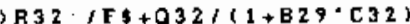




\section{TABLE B.6. contd}

$3032: 1 F 3+D 32-E 32-E 32-G 32-132-032-P 32+Q[F(C 32=87,89 M B 3,0)$

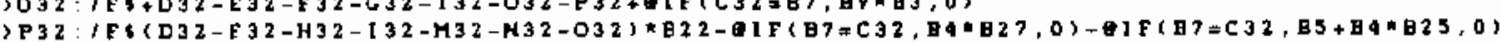

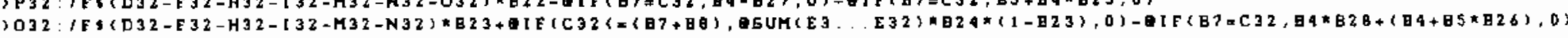

IN3 2:/FI+L32*85/100

IM32:IF $1+K 32 \times 841100$

$>\mathbf{1} 3 \mathbf{2}: 0$

$>\times 32: 0$

J3 $32:+32$

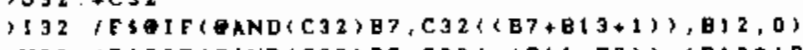

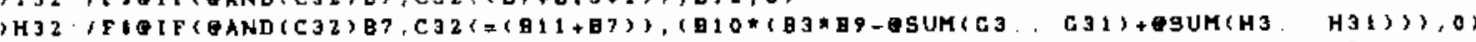

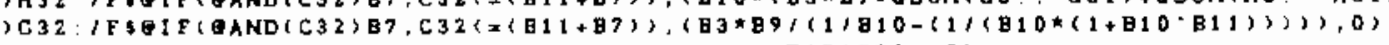

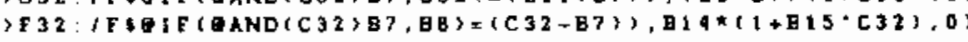

SE $35:$ : 530

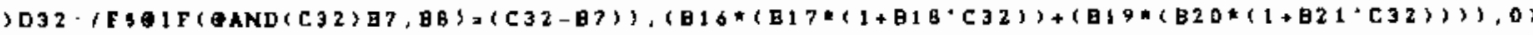

$>\mathrm{CB}_{3} \cdot 1+\mathrm{C} 3 \mathrm{I}$

> $831 \cdot 185+031 /(1+829 \cdot C 31)$

$3031: / F 3+D 31-E 31-F 31-C 31-I 31-031-F 31+8 I F(C 31=B 7,89 \times B 3,0)$

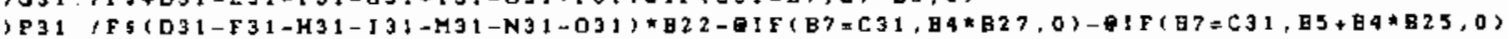

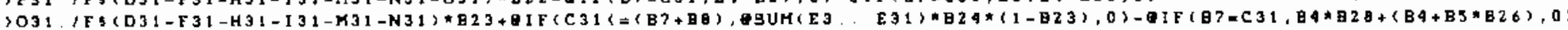

$3 N 3 !: 1 E S+L 31 * B 51100$

M31: $/ E \$+K 31 * 8+1100$

3L $31: 0$

$3 \mathbf{3} 3 \mathbf{1}: 0$

$3 \mathrm{~J} 31:+\mathrm{C} 31$

) I 31 : IFSEIF\{OAND(C31)B?, C31((87+B13+1)), 122,0$)$

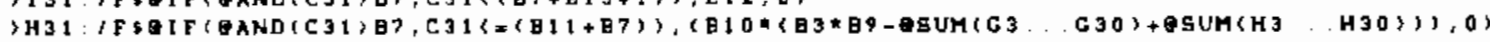

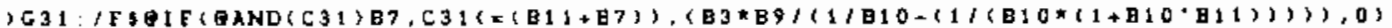

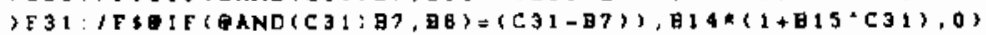

IE 1 T TSO

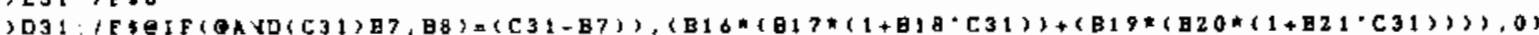

$\rightarrow C 3: 1+C 30$

$3,130,153+030$

(0) $30(1+829 \cdot(30)$

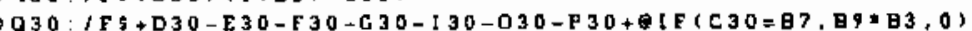

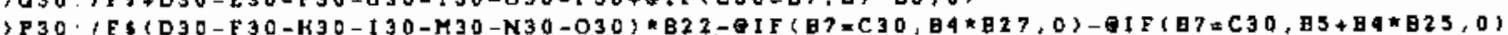

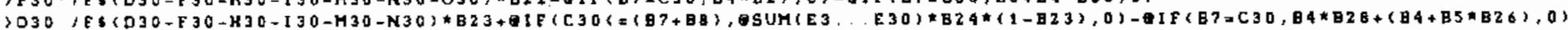

$3 N 30: 159+\angle 30 * B 51100$

$1430: 1 F+K 30 \times 84 / 100$

, L $30: 0$

IK $30: 0$

$330 \cdot+\mathrm{C} 30$

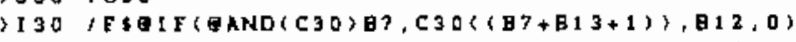

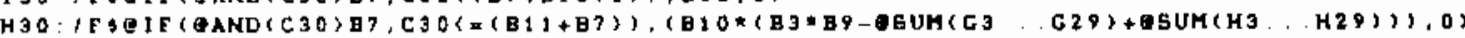

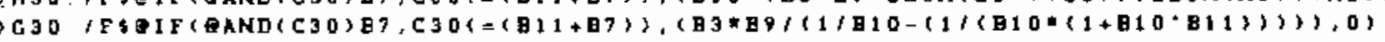

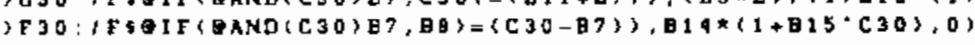

>E $30: / \mathrm{F} \$ 0$

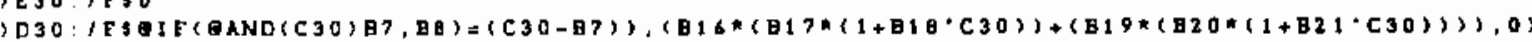

$>C 30: 1+C 29$

TR29: $/ F 3+029 /(1+B 29 \cdot C 29)$

ᄀQ29 $153+D 29-E 29-F 29-C 29-129-029-F 29+\theta I E(C 29=B 7, B Q+B 3,0)$

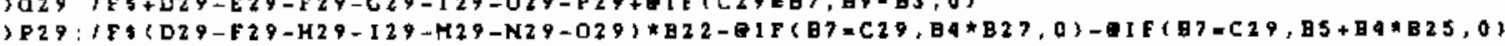

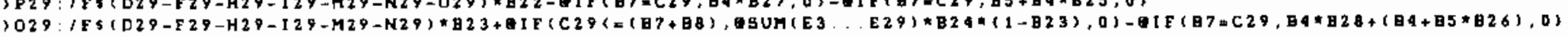

IN29: $/ F 3+229 * B 5 / 100$

IM29:/Fs+K29*B4/100

$>229: 0$

$3 \times 29 \cdot 0$ 
TABLE B.6. contd

$329:+2.89$

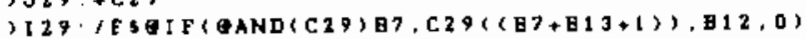

) 29 . $F 8$ E

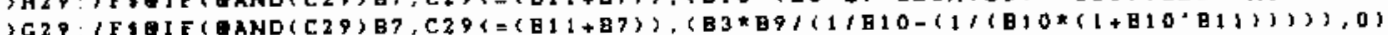

(2) 290

SE $29 \cdot 1 F 50$

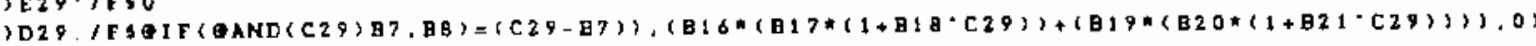

$>C 29: 1+C 2 B$

\E29: IER I

$>$ A29: "DISCOUNT RAT

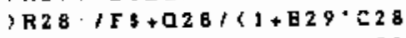

$3028: / F \$+028-E 26-E 2 B-G 2 B-128-O 2 B-P 2 B+\theta I F(C 2 B=B 7, B 9 * B 3,0$

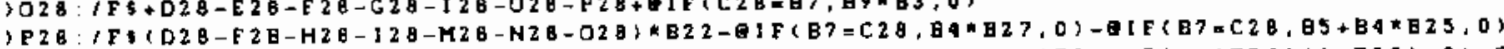

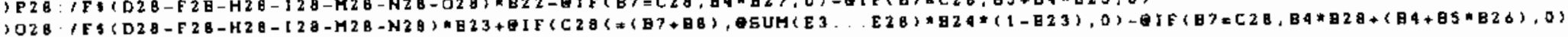

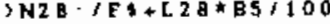

$2 M 2 B: / F \$+X 2 B * B 4 / 100$

IL $28: 0$

$>K 2 B \cdot 0$

$32 \mathrm{JB}+\mathrm{C} 2 \mathrm{~B}$

$312 B-(F) A I F(B A N D(C 2 B) \theta 7, C 2 B((B)+B 13+1)), B 12,0)$

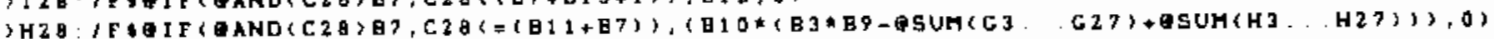

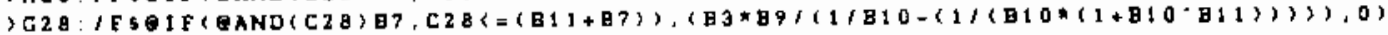

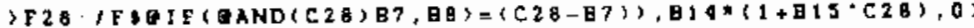

$328: / 650$

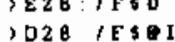

$3028 \cdot 1+C 27$

$3 \mathrm{~B} 2 \mathrm{Q}$. IFRO

3A2B: "STE SOL TAY CA

)R2?: $/ F 3+Q 27)(1+B 29 \cdot C 27)$

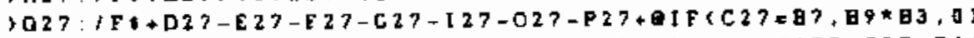

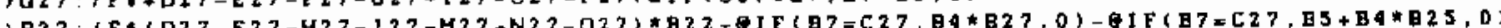

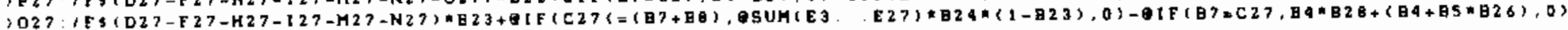

$3 N 27,1 F S+[27 * 85 / 100$

$3 M 27,1 F S+K 27 * B 41100$

IL 2 ? :0

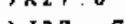

IJZ7: C CZ7

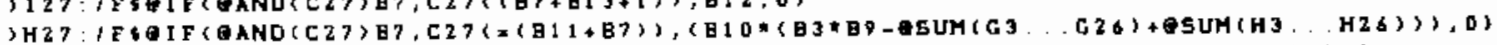

3 C2? IFSEIF(GAND(C2)

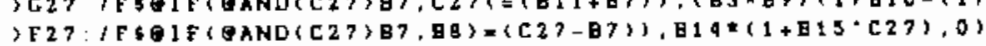

$, 253,1530$

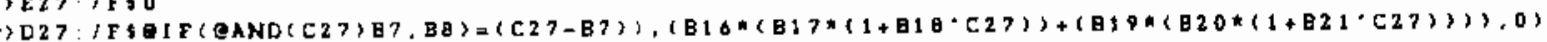

$327: 1+C 26$

SB27: /FRO

SA27: "FED SOL TAX CR

IR26: / FS+Q26) $(1+B 29 \cdot C 26)$

$2026: / F \$+D 26-E 26-E 26-C 26-126-026-P 26+Q+F(C 26=B 7, B 9 * B 3,0)$

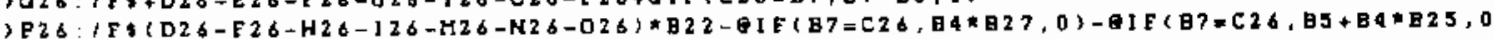

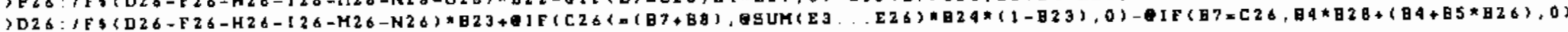

IN26: /F\$+L26*B5/100

$2 M 26: / F 5+K 26 A B 4 / 200$

ऽ.26:0

$>\mathrm{J} 26:+\mathrm{C} 26$ 


\section{TABLE B.6. contd}

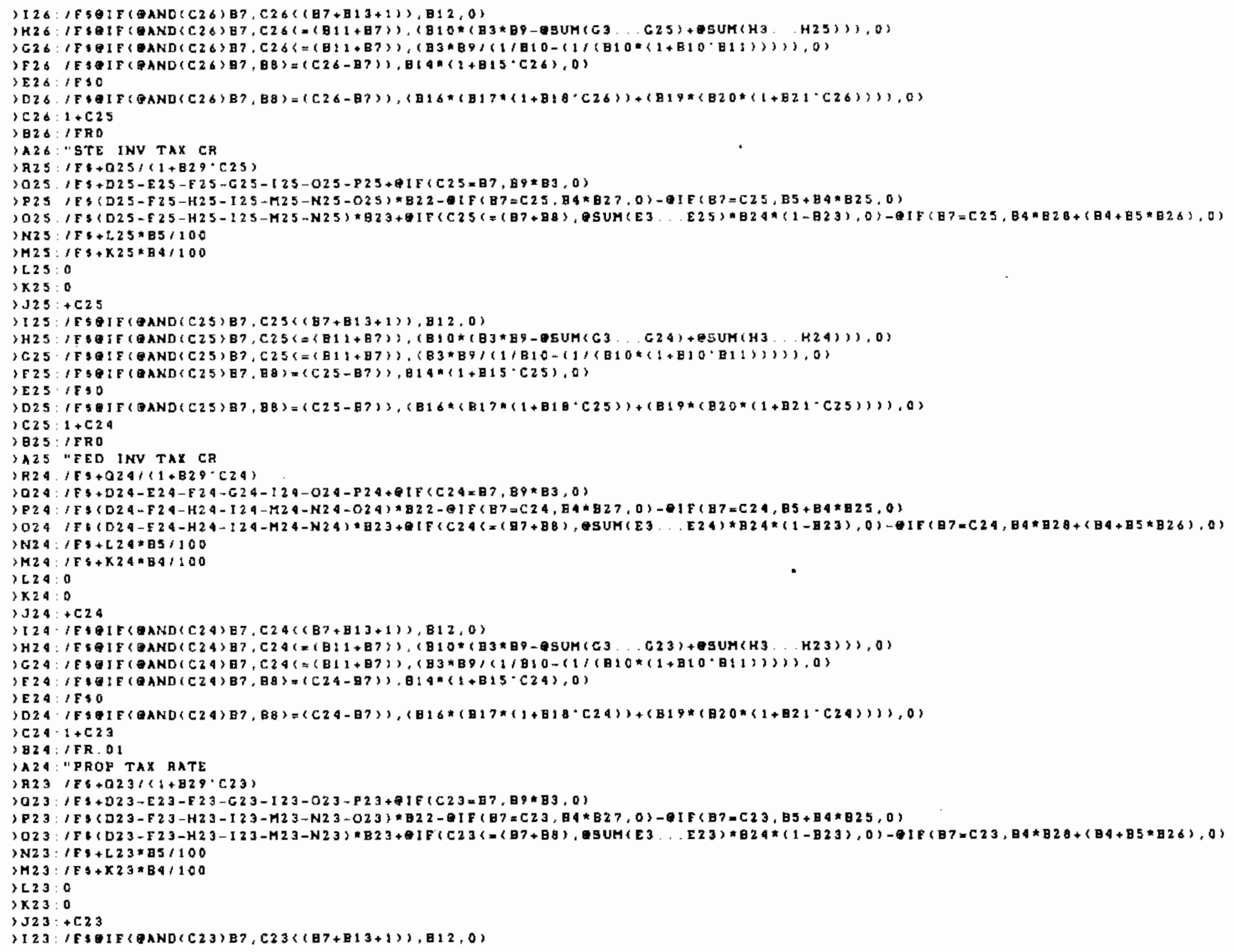


TABLE B.6. contd

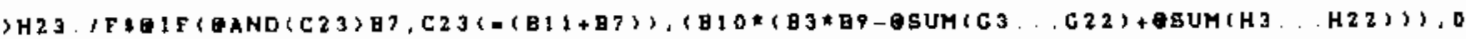

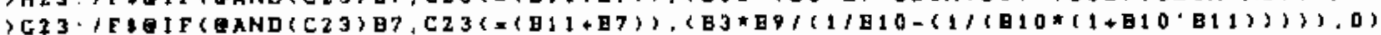

C23.7F3日IF

150.150

DZ3. FseIE(OAND(C23)

C $23 \cdot 1+C 22$

$923: 1$ FR. 096

A23: "STATE TAX RATE

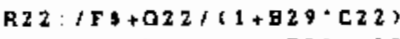

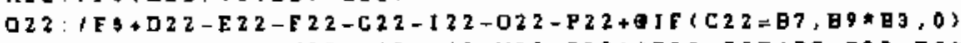

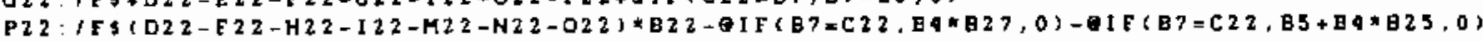

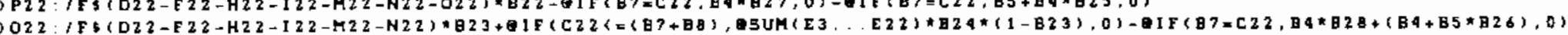

SN22: $/ E \$+L 22 * B 5 / 100$

$M 22 \cdot 1 F 6+K 22 * B 4 / 100$

>L.Z2:0

K $22: 0$

$1 \mathrm{J22}+\mathrm{C2Z}$

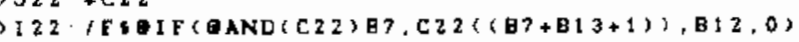

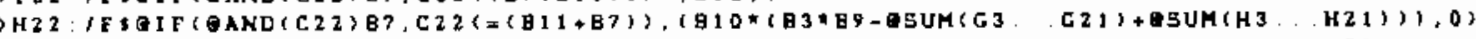

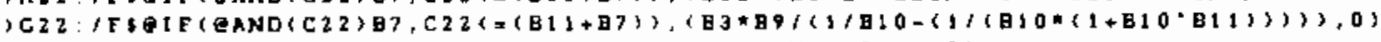

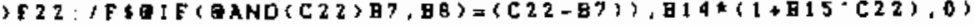

IE2: 2 : 5 SO

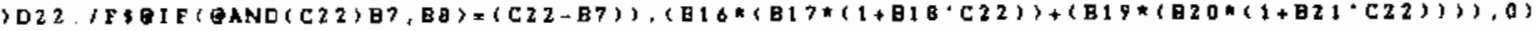

$1 \mathrm{C2} 2 \cdot 1+\mathrm{C} 21$

CD

(A21: $\mathrm{FS}+\mathrm{Q} 21 /(1+\mathrm{B} 29 \cdot \mathrm{C} 21)$

SO21: IFS $+D 21-E 21-F 21-C 21-121-021-P 23+Q I F(C 21 \times B 7, B 94 B 3,0)$

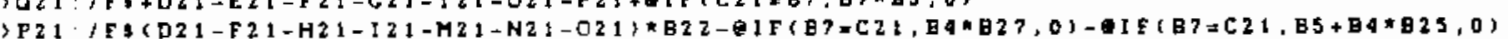

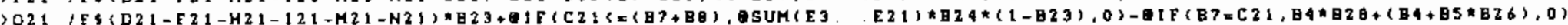

N21: $1 F\}+221 * B 5 / 100$

M21. $/ F \$+X 211+B 91100$

$>$ I. 210

(ग)

$\mathrm{J} 21:+\mathrm{C} 21$

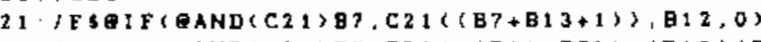

F

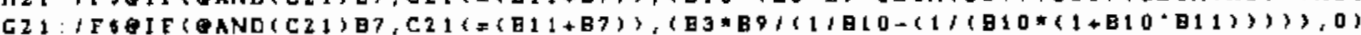

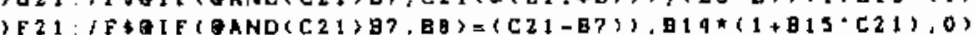

E 21 I $F \leq 0$

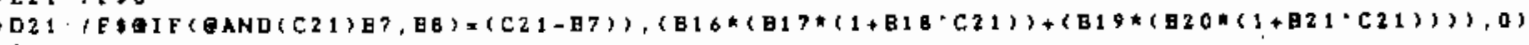

C $21: 1+C 20$

B21: $/ \mathrm{FF} .08$

A2 I: /FF"ESC RATE

$3 A 20: 1 E 5+020 /(1+B 29+C 20)$

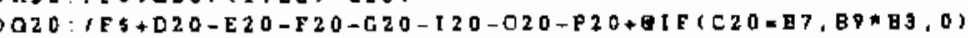

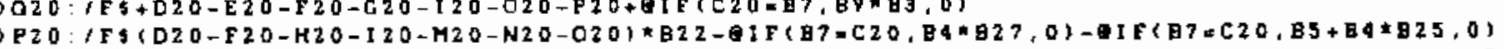

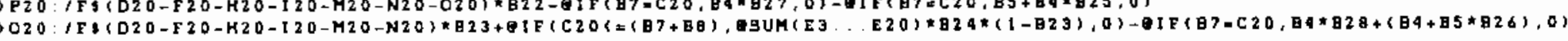

$>N 20: / F 3+L 20 * B 51100$

H3D: $/ F \$+K 20184 / 100$

IL $20: 0$

$\checkmark K 20: 0$

$>020+\mathrm{C} 20$

I $20: / F S \theta I F(\operatorname{AND}(C 20) \theta 7, C 20\{(B 7+B 13+1)), B 12,0)$

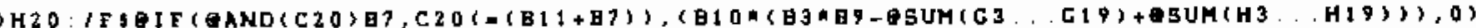


TABLE B.6. contd

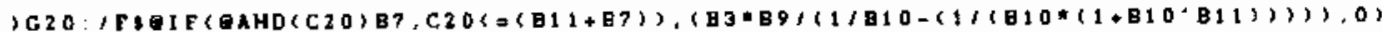

)E $20: / F 301 F(B A N D(C 20) B 7, B B)=\{C 20-B 7\}), B 14$ A $(1+B 15-C 20), 0)$

SE $20: 1530$

)D20: IFs

$>C 20: 1+C 19$

$3 \mathrm{B20}:$ FR O3

,A2O: "PAICE ENCY DISE

SA1 $\left.9 \cdot 1 F T^{\circ}+019111+B 29 \cdot C 19\right)$

DI9: $1 F 3+D 19-E 19-F 19-C 19-119-019-P 19+91 E(C 19=B 7, B 9+E 3,0)$

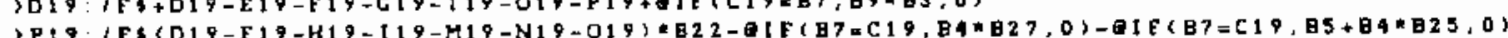

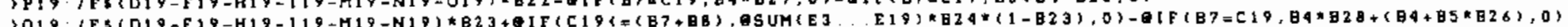

SN19:/FS+L19:BS/100

$1419.159+x 19 * 841000$

$\begin{array}{rll}3 \\ 3 \times 19 & 0\end{array}$

$3 \mathrm{J19}+\mathrm{C} 19$

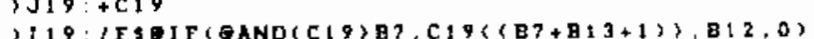

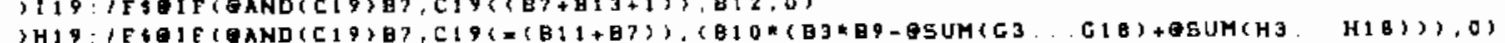

, $C 19$.

,F 19 . (F⿻二丨

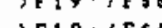

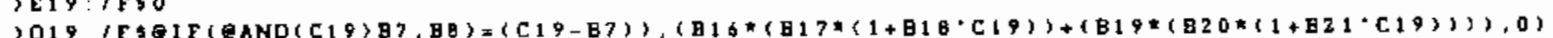

$>C 19: 1+C 1 \theta$

SBI T: IER7008DOOO

SAI9: "AMT ENGY DISP

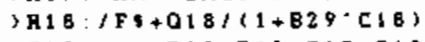

$2018: J F 5+D 18-E 18-F 18-C 18-118-018-P 18+C 1 F(C 18-B 7, B 9 * B 3,0)$

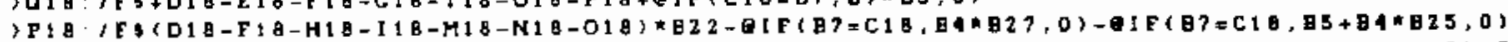

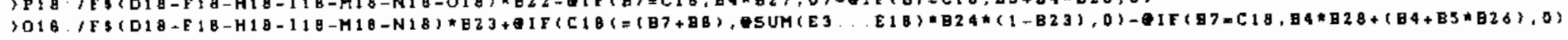

TN1B: $/ F S+L 18 N B S / 100$

SM1B: $1 F B+K 18 * B 41100$

II 18:0

IKIB:O

J1B: $+C_{1 B}$

IIIB TSSIF(EAND(C1B)B?, C1B((B)+B13+1)), B12,0

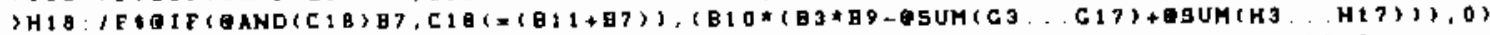

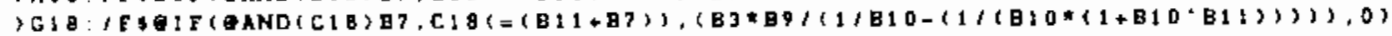

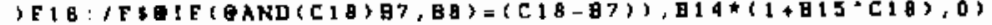

IE $10: / F \div 0$

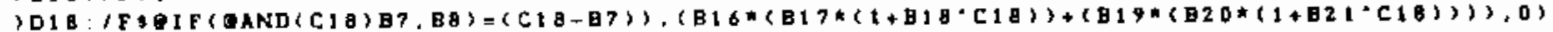

$Y C 18: 1+C 17$

SB: A: /ER. 08

IAIG: /FR"ESC RATE

) R1 $\{: F s+017 /\{1+B 29 \cdot C 17\}$

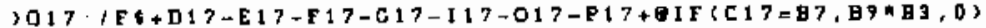

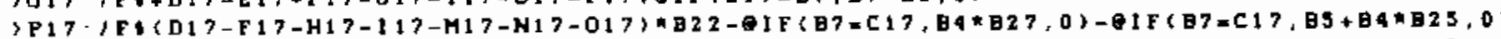

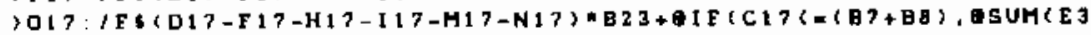

$3 \mathrm{~N}^{2} 7: / \mathrm{F} 3+\mathrm{L} 17 * \mathrm{BS} / 100$

IM17: IFB+X17NBA/100

IIT?:O

$\mathbf{X 1 7 : 0}$

S $17:+C 17$

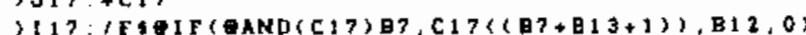

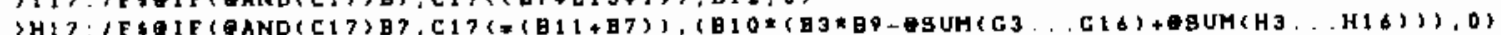

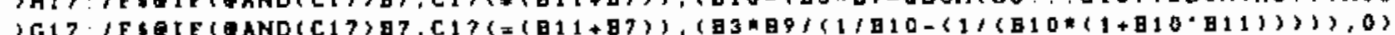


TABLE B.6. contd

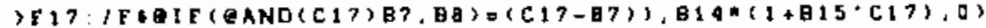

$\rightarrow E, T=1530$

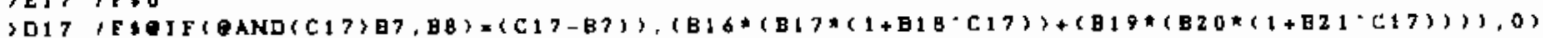

,$C 17 \cdot 1+C 16$

B17: IFB 075

A17 "PAICE ENGY SOLD

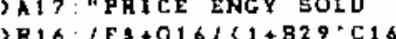

OQ16 $1 F 9+016-E 16-F 16-C 16-116-016-P 16+81 F(C) 16=87,89 * B 3,0)$

P16.

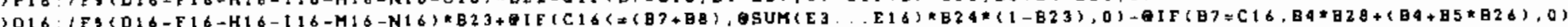

N16. $1 F 3+116 * 85 / 100$

$2 M 16 \cdot 1 F 5+K 16 * 841100$

I $16 \cdot 0$

stis 0

$316:+C 16$

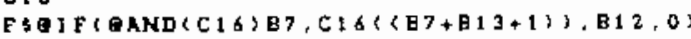

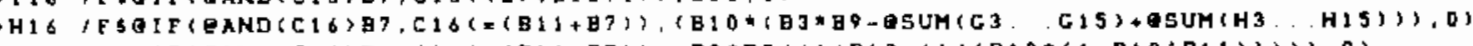

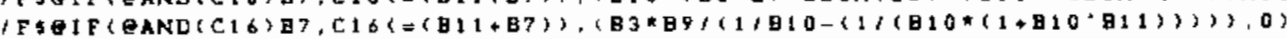

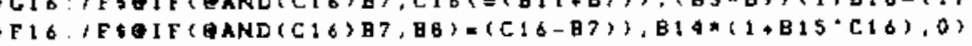

E16:IF\$O

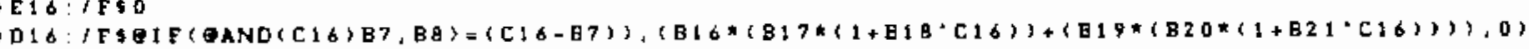

IC:6:1+C:15

BI6. /FRO

A16: "AMT ENGY SOLD

RIS $/ F 5+015 /(1+B 29 \cdot C 15)$

O1S: $1 F 3+D 15-E 15-F 15-C 15-115-015-P 15+Q 1 F(C 15 \times B 7, B 9 * B 3,0)$

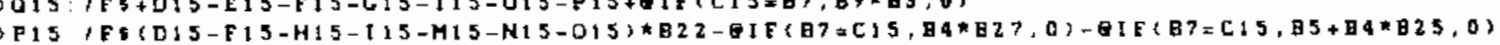

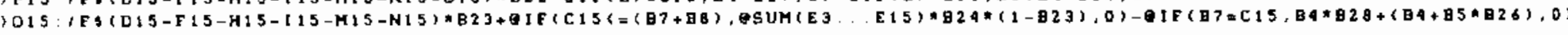

N15:/F $15+115 * 85 / 100$

M15:/Et+K15*BA/1100

$3 \pm 15 \cdot 0$

ik 150

$315:+C 15$

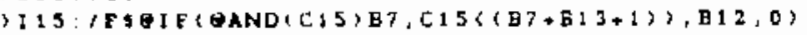

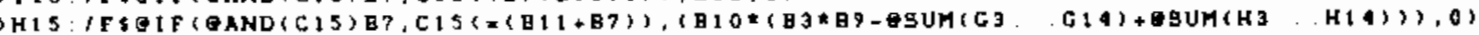

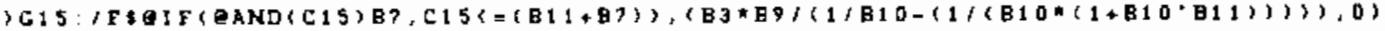

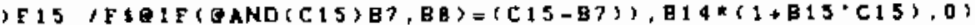

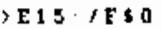

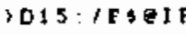

C $15: 1+C 19$

A15: "OSM ESC RATE

$R ! 4:\{F 5+Q 19\{(1+829 \cdot C 14\}$

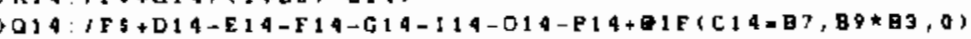

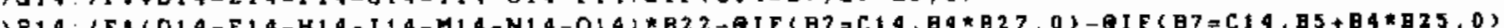

(O)

SN14: IF $5+L 14 * 05 / 100$

M14. $/ F \$+K 14 * B 4 / 100$

$>\operatorname{Li} 4: 0$

$3 \mathrm{~K} 14: 0$

J14: + C 14

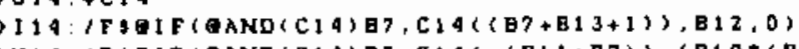

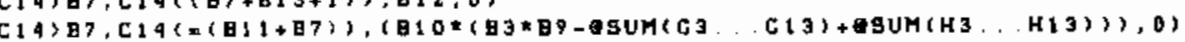

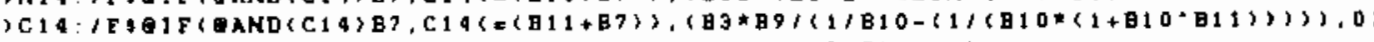

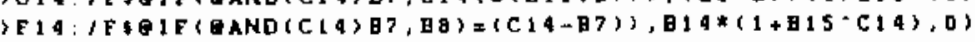


TABLE B.6. contd

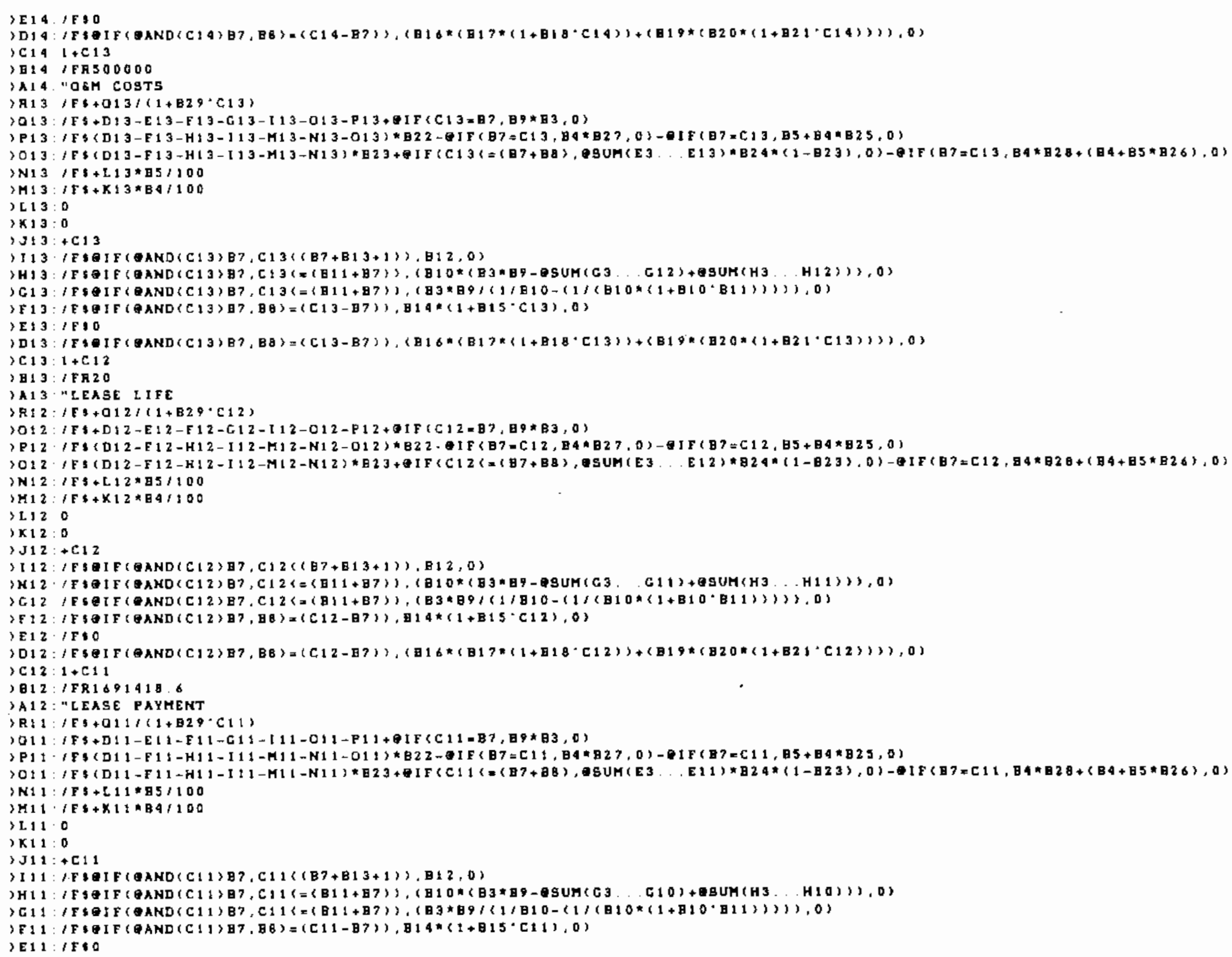




\section{TABLE B.6. contd}

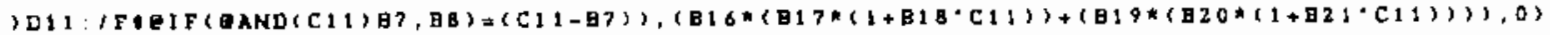

C $11: 1+C: 0$

A11: "LOAN LTFE

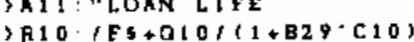

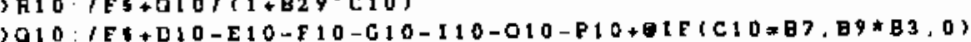

(D)

P10 (E)

N10. TES + L 10 OBS 100

M10: $/ F+4 K ! O \times 84100$

IL 10.0

,$\times 10.0$

$310:+\operatorname{Cos} 10$

I10.TFSQIE (EAND(C10)B7, C10<(B?+B13+1)),B12,0)

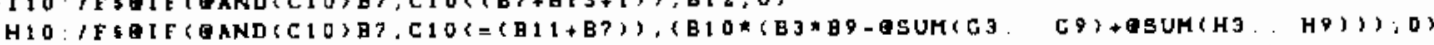

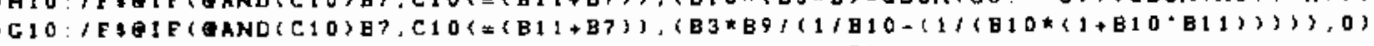

F10, F SQIE(BAND $(C 10) B ?, B B)=(C 10-B 7)), B 19 \times(1+B 15 \cdot C 10), 0)$

SE10:1F\$0

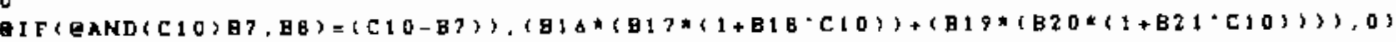

IC: $0: 1+C 9$

IB10: IFA. 1

SA10: "LOAN INT FATE

तA : $159+091(1+829 \cdot C 9)$

>09. $C F+D 9-E 9-F 9-C 9-19-09-P 9+I F(C 9=87, B 9=B 3,0)$

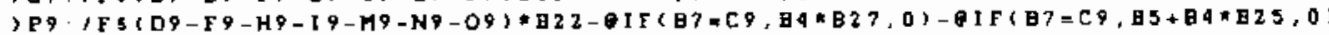

$\operatorname{IS:}: 0$

$3 x, 0$

ग $39:+C 9$

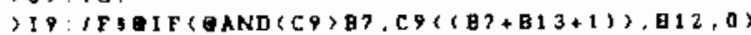

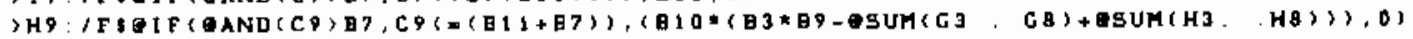

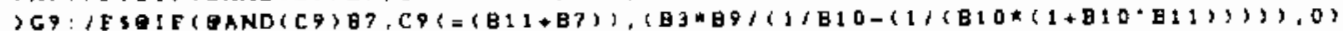

FQ. $F S Q 1 F($ AND $(C 9) B 7, B B)=(C 9-B 7)), 814 *(1+815 \cdot C 9), D)$

IEQ: IFSO

D9.

$>C 9: 1+C a$

SBQ: /FF-. S

उA9: "DEET FRACTYON

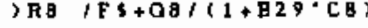

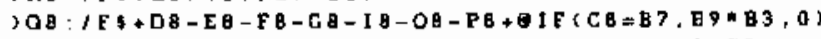

(

OB: $\mathrm{E}$ (

INB: $/ F+L B * B=1 / 100$

SMB: IFB+KB*B4/10

$>$ I. B : 0

YX: : 0

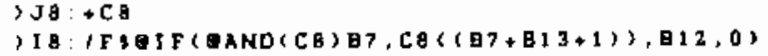

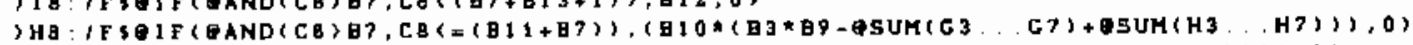

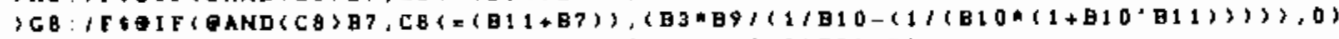

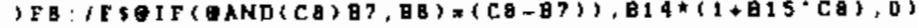

IEB: / $F=0$

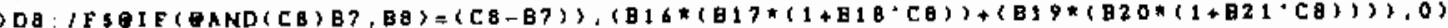


TABLE B.6. contd

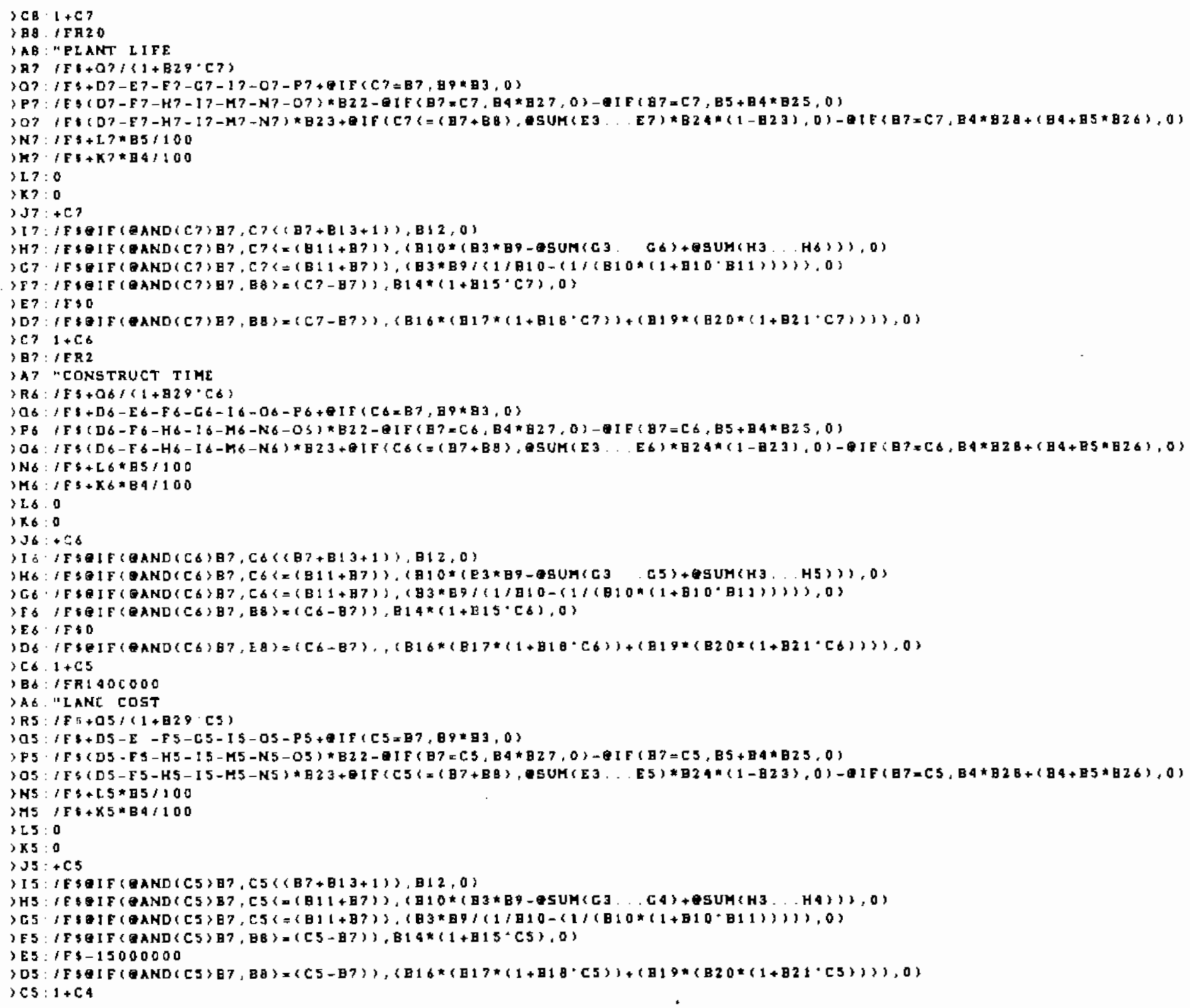


TABLE B.6. contd

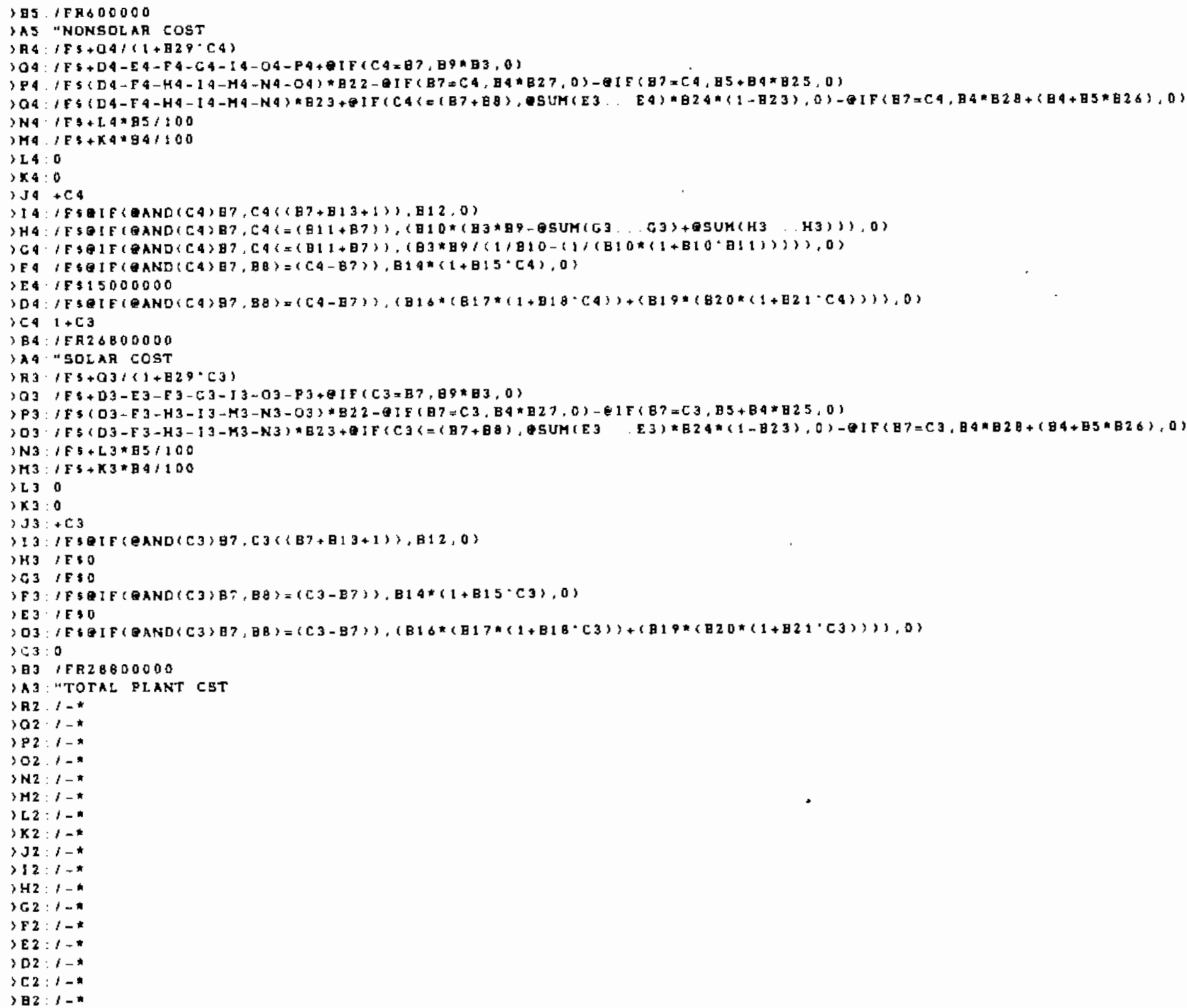


TABLE B.6. contd

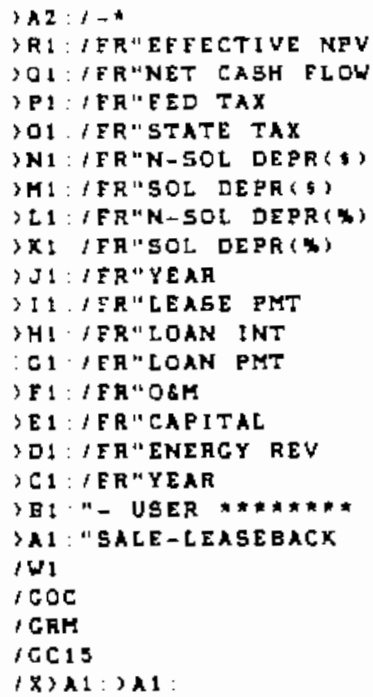




\section{DISTRIBUTION}

No. of

Copies

OFFSITE

J. B. Woodard

Division 8454

Sandia National Laboratory

Livermore, CA 94550

27 DoE Technical Information Center

A. C. Skinrood

Division 8452

Sandia National Laboratory

Livermore, CA 94550

J. B. Wright

Division 8450

Sandia National Laboratory

Livermore, CA 94550

W. G. Wilson

Division 9453

Sandia National Laboratory

Livermore, CA 94550

H. F. Norris

Division 8452

Sandia National Laboratory

Livermore, CA 94550

W. C. Peila

Division 9453

Sandia National Laboratory

Livermore, CA 94550

T. A. Williams

Division 9454

Sandia National Laboratory

Livermore, CA 94550

G. W. Braun

U.S. Department of Energy

Div. of Solar Thermal Technology

Forrestal Building, Rm. 5H021I

1000 Independence Ave., S.W.

Washington, D.C. 20585
No. of

Copies

OFFSITE

C. B. McFarland

U.S. Department of Energy

Div. of Solar Thermal Technology

Forrestal Building, Rm 5HO2lI

Code CE-314

1000 Independence Ave., S.W.

Washington, D.C. 20585

M. R. Scheve

U.S. Department of Energy

Div. of Solar Thermal Technology

Forrestal Bujlding, Rm 5HO2lI

Code CE-314

1000 Independence Ave., 5.W.

Washington, D.C. 20585

K. T. Cherian

U.S. Department of Energy

Div. of Solar Thermal Technology

Forrestal Building, Rm 5H021I

Code CE-314

1000 Independence Ave., S.W.

Washington, D.C. 20585

G. N. Pappas

U.S. Department of Energy

Albuquerque Operations office

Special Programs Division

PO Box 5400

Albuquerque, NM 87115

T. F. Heenan

U.S. Department of Energy

San Francisco Operations office

1333 Broadway

Oakland, CA 94612

R. W. Hughey

U.S. Department of Energy

San Francisco Operations Office

1333 Broadway

Oakland, CA 94612 
No. of

Copies

OFFSITE

V. C. Truscello

Jet Propulsion Laboratory 4800 0ak Grove Drive

Pasadena, CA 91103

E. 5. Davis

Jet Propulsion Laboratory

4800 0ak Grove Drive

Pasadena, CA 91103

H. Habib-agahi

Jet Propulsion Laboratory

4800 0ak Grove Drive

Pasadena, CA 91103

J. Bigger

EPRI

PO Box 10412

3412 Hillview Avenue

Palo Alto, CA 94303

E. A. DeMeo

EPRI

PO Box 10412

3412 Hillview Avenue

Palo Alto, CA 94303

B. Gupta

SERI

1617 Cole Boulevard

Golden, CO 80401

K. 01 sen

SERI

1617 Cole Boulevard

Golden, C0 80401

B. Butler

SER I

1617 Cole Boulevard

Golden, C0 80401
No. of

Copies

OFFSITE

A. 2. V11man

Energy Systems Corp.

Rockwell International

8900 De Soto Avenue

Canoga Park, CA 91304

Eric R. Weber

Arizona Public Service Company

P0 Box 21666

Phoenix, AZ 85036

George St. John

AMFAC Energy, Inc.

PO Box 3230

Honolulu, HI 96801

James E. Brown

El Paso Electric Company

PO Box 982

El Paso, TX 79960

Ted Fick

Bechtel Group, Inc.

50 Beale Street

San Francisco, CA 94119

Keith Rose

U.S. Department of Energy

San Francisco Operations office 1333 Broadway

0akl and, CA 94612

B. L. Broussard

Arizona Public Service Company

P0 Box 21666

Phoenix, AZ 85036

K. G. Davidson

Gas Research Institute

8600 West Bryn Mawr Avenue

Chicago, IL 60731 
No. of

Copies

\section{OFFSITE}

J. C. Grosskreutz

Black \& Veatch Consulting Engrs. P0 Box 8450

Kansas City, MO 64114

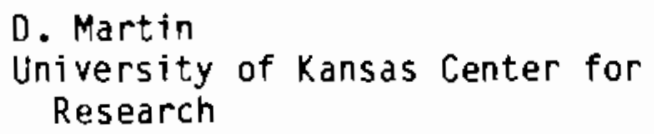

D. Schieffel

ARCO Ventures Company

515 South Flower Street

Los Angeles, CA 90071

T. H. Springer

Rockwell International

Energy Systems Group

8900 De Soto Avenue

Canoga Park, CA 91304

c. La Porta

4618 Nottingham Drive

Chevy Chase, MD 20815

E. Ney

Georgia Power Company

7 Solar Circle

Shenandoah, GA 30265

J. S. Bichler
Central Solar Energy Res. Corp
1200 Sixth Street
358 Executive Plaza
Detroit, MI 48226

P. Mathur

Aerospace Corporation

P0 Box 92957

Los Angeles, CA 90009

J. Yudelson

Solar Initiative

162 Christen Drive

Pacheco, CA 94553
No. of

Copies

OFFSITE

S. Biddle

Renewable Energy News

P0 Box 38

Spinnerstown, PA 18968

J. Grissett

C. B. Day Co., Inc.

2751 Buford Hwy. N.E.

At lanta, GA 30324

H. Seielstad

Pacific Gas \& Electric

3400 Crow Canyon Rd.

San Ramon, CA 94583

J. Montague

Martin Marietta Corp.

P0 Box 179

Denver, CO 80201

K. Feng

U.S. GAO, LA Regional office

World Trade Center, Suite 1010

350 S. Figueroa Street

Los Angeles, CA 90071

A. Jenkins

Cal ifornia Energy Commission

1516 Ninth Street

Sacramento, CA 95814

P. 80 s

Polydyne, Inc.

1230 Sharon Park Dr.

Suite 61

Menlo Park, CA 94025

H. Morse

Acurex Solar Corp.

485 Clyde Ave.

Mountain View, CA 94042

G. Hutchinson

Solar Kinetics, Inc.

8120 Chanceltor Row

Dallas, IX 75247 
No. of

Copies

OFFSITE

L. Katz

American University

327 Letts $\mathrm{Hall}$

Washington, D.C. 20016

S. D. Elliot

U.S. Department of Energy

Solar Energy Division

P0 Box 366

Daggett, CA 92327

R. Gervais

McDonnell Douglas Astronautics Co.

5301 Bolsa Ave.

Huntington Beach, CA 92647

R. Hallet

McDonnell Douglas Astronautics Co. 5301 Bolsa Ave.

Huntington Beach, CA 92647

\section{J. Raetz}

McDonnell Douglas Astronautics Company

5301 Bolsa Ave.

Huntington Beach, CA 92647

3. Roland

McDonnell Douglas Astronautics Co. 5301 Bolsa Ave.

Huntingt on Beach, CA 92647

J. N. Reeves

Southern California Edison

P0 Box 800

Rosemead, CA 91770

P. E. Skvarna

Souther California Edison

PO Box 366

Daggett, CA 92327

T.L. Willke

Gas Research Institute

8600 West Bryn Mawr Avenue

Chicago, IL 60731
No. of

Copies

ONSITE

DOE Richland Operations Office

H. E. Ransom

R. K. Stewart

23 Pacific Northwest Laboratory

W. B. Ashton

C. H. Bloomster

D. R. Brown (5)

J. A. Dirks

K. Orumbeller

B. A. Garrett-Price

H. Marty

S. A. Smith

L. D. Willians

Economics Library (3)

Technical Information (5)

Publishing Coordination (2)

9 Battelle-Human Affairs Research Centers

R. Cole (5)

P. Sommers

I. Holmlund

S. Malhotra

E. Edelhertz 
